LINO JOSÉ CARDOSO SANTOS

AVALIAÇÃO DO CICLO DE VIDA E CUSTEIO DO CICLO DE VIDA DE EVAPORADORES PARA USINAS DE AÇÚCAR 
LINO JOSÉ CARDOSO SANTOS

\section{AVALIAÇÃO DO CICLO DE VIDA E CUSTEIO DO CICLO DE VIDA DE EVAPORADORES PARA USINAS DE AÇÚCAR}

Tese apresentada à Escola Politécnica da Universidade de São Paulo para a obtenção do Título de Doutor em Engenharia. 


\section{AVALIAÇÃO DO CICLO DE VIDA E CUSTEIO DO CICLO DE VIDA DE EVAPORADORES PARA USINAS DE AÇÚCAR}

Tese apresentada à Escola Politécnica da Universidade de São Paulo para a obtenção do Título de Doutor em Engenharia.

Área de Concentração: Engenharia Metalúrgica e de Materiais.

Orientador: Prof. Dr. Jorge Alberto S. Tenório 
Este exemplar foi revisado e alterado em relação à versão original, sob responsabilidade única do autor e com a anuência de seu orientador.

São Paulo, de outubro de 2007.

Assinatura do autor

Assinatura do orientador

FICHA CATALOGRÁFICA

Santos, Lino José Cardoso

Avaliação do ciclo de vida e custeio do ciclo de vida de evaporadores para usinas de açúcar / L.J.C. Santos. -- ed.rev. -São Paulo, 2007.

$227 \mathrm{p}$.

Tese (Doutorado) - Escola Politécnica da Universidade de São Paulo. Departamento de Engenharia Metalúrgica e de Materiais.

1.Evaporadores 2.Aço inoxidável 3.Ciclo de vida (Avaliação; Custeio) 3.Indústria açucareira 4.Seleção de materiais I.Universidade de São Paulo. Escola Politécnica. Departamento de Engenharia Metalúrgica e de Materiais Il.t. 


\section{DEDICATÓRIA}

Dedico este trabalho aos meus pais,

Odete e Sylvio. 


\section{AGRADECIMENTOS}

Ao Professor Dr. Jorge Alberto Soares Tenório, pela orientação segura, objetiva e competente, bem como pelo estímulo constante à conclusão deste trabalho.

À Maria de Fátima Almeida, a quem sou muito grato por ter recebido o Diploma de Mestrado.

Ao Professor Dr. Hélio Wiebeck, grande amigo e companheiro constante ao longo de todo este doutorado.

Aos colegas de sala de aula e, em especial, ao amigo Reynaldo Pini.

À Maria Lúcia Attar, Maria Aparecida Silva e Fátima Roldan, amigas da Biblioteca da Engenharia Química, pela colaboração e incentivo permanentes.

Ao Núcleo Inox e, em especial, ao Sr. Arturo C. Maceiras, Diretor Executivo e ao Dr. Marcelo de Castro Rebello, Consultor, pela valiosa contribuição na definição do tema, nos comentários ao longo de todo o trabalho, incentivo, confiança e sólida amizade.

Ao companheiro José Roberto de Andrade, pelo acesso que me proporcionou a várias usinas de açúcar.

Ao amigo Luiz Carlos da Silva, colaborador de todas as horas e o meu grande Professor de tecnologia açucareira.

À Usina Pumaty S. A., pela contribuição na definição do ciclo de vida desta tese de doutorado.

Aos Professores Drs. Gil Anderi da Silva e Jorge Horii, pelos valiosos conselhos. 
Aos amigos Luiz Gualberto, José Luiz Castilho e Luiz Maugè pela valiosa contribuição na fase final deste trabalho.

Ao grande amigo e companheiro desde a graduação Aldo Baccarin, pelo apoio constante, que foi essencial à execução desta tese.

Às amigas e amigos da Food Intelligence, pela cobrança e incentivo à conclusão desta tese.

À Jandira, aos meus irmãos, familiares, parentes e amigos queridos que sem o seu amor, carinho e torcida não seria capaz de superar este desafio.

À Janete, Tais e Eduardo, esposa e filhos amados, pelo amor, carinho, incentivo permanente e compreensão pelos momentos furtados do convívio familiar.

A Deus, por ter estado sempre ao meu lado, dando-me saúde, força, amigos e determinação, sem os quais este desafio não seria vencido. 
"Não sabendo que era impossível, foi lá e fez." 


\section{RESUMO}

O setor de açúcar e álcool etílico no Brasil tem experimentado um grande crescimento. Contribuem para isto as demandas crescentes do álcool etílico, um biocombustível, e do açúcar. A área industrial produtora de açúcar, um alimento, ainda convive com uma prática industrial ultrapassada, que vem a ser o uso do aço carbono, um material barato, mas com pequena resistência à corrosão. Os aços inoxidáveis são os materiais mais indicados para a substituição do aço carbono, entretanto, eles são considerados caros. Os evaporadores das usinas de açúcar são equipamentos importantes para a sua operação. Quando são usados tubos de aço carbono para a troca térmica, eles começam a ser substituídos a partir do segundo ano de operação devido à corrosão. Enquanto isso, os tubos em aços inoxidáveis podem durar décadas. O presente trabalho objetivou a avaliação do desempenho ambiental e financeiro de tubos para evaporadores construídos com aço carbono e, comparativamente, com os aços inoxidáveis 304, 444 e 439. Para alcançar estes objetivos foram utilizadas as metodologias de Avaliação do Ciclo de Vida (ACV) e de Custeio do Ciclo de Vida (CCV), respectivamente. Neste estudo de ACV foi adotada como função dos sistemas em estudo a massa de água evaporada. Na definição destes sistemas de produtos foram adotados os subsistemas de fabricação das bobinas de lâminas dos aços e fabricação, instalação e limpeza dos tubos. O consumo de gás natural, eletricidade e o transporte foram usados como subsistemas secundários. O período de avaliação destes sistemas foi de trinta anos. A partir dos resultados desta ACV, concluiu-se que os tubos em aço carbono apresentaram maior impacto ambiental que os tubos em aço inoxidável 304, 444 e 439, pois emitiram mais que 4,2 vezes a quantidade de dióxido de carbono; 2,8 vezes a de óxidos de nitrogênio; 3,1 vezes a de materiais particulados, 13 vezes a de materiais suspensos e 4,5 vezes a de resíduos totais. Os tubos em aço carbono consumiram também mais que 11 vezes o total de recursos naturais utilizados (carvão; lignita; calcita; dolomita; óleo; gás natural e minérios de ferro, cromo, níquel, molibdênio e manganês); 1,8 vezes a de água e 5 vezes a de energia. Com relação à emissão de óxidos de enxofre, os tubos em aço carbono emitiram quantidades semelhantes às emitidas pelos tubos em aços 444 e 439 e a metade que os tubos em aço 304 . Na elaboração do CCV foram utilizados os componentes de custo compra, transporte, 
instalação, substituição e limpeza dos tubos e a venda das sucatas. Na avaliação financeira, todos os custos que aconteceram no período de trinta anos foram trazidos ao valor presente. A partir dos resultados obtidos concluiu-se que os aços inoxidáveis 439 e 444 apresentaram-se como opções de investimento mais interessantes que os tubos fabricados em aço carbono, já que apresentaram custos trazidos ao valor presente menores, na proporção de 0,76 para os tubos em aço 439; 0,79 para os tubos em aço $444 \mathrm{com} 1,20 \mathrm{~mm}$ de espessura e 0,93 para tubos em aço $444 \mathrm{com} \mathrm{1,50} \mathrm{mm} \mathrm{de} \mathrm{espessura.} \mathrm{Os} \mathrm{tubos} \mathrm{em} \mathrm{aço} 304 \mathrm{com} \mathrm{1,20} \mathrm{mm} \mathrm{de}$ espessura apresentaram desempenho financeiro semelhante aos tubos em aço carbono; enquanto que os tubos em aço $304 \mathrm{com} \mathrm{1,50} \mathrm{mm} \mathrm{apresentaram} \mathrm{custos} \mathrm{ao}$ valor presente 1,19 vezes maior. Os resultados obtidos indicam também que as metodologias ACV e CCV devem ser usadas em conjunto, pois mostram que produtos mais seguros ambientalmente podem vir a ser opções de investimentos também mais interessantes.

Palavras-chave: ACV. Avaliação do ciclo de vida. CCV. Custeio do Ciclo de Vida. Tubos para evaporadores. Usinas de açúcar. Aço carbono. Aço inoxidável. Seleção de Materiais. Sustentabilidade. 


\section{ABSTRACT}

The sugar and ethanol sectors in Brazil have tried a great growth. The increasing demands for ethanol, a biocombustible, and for the sugar contributes for this situation. The producing industrial area of sugar, a foodstuff, still adopts the use of carbon steel pipes, a cheap product, of low corrosion resistance. The stainless steels are the materials more indicated for the substitution of carbon steel, however they are considered expensive. In sugar cane plants, the evaporators, are important equipments to operation. Carbon steel pipes are the main product used for the thermal exchange, and these pipes start to be replaced after the second year of operation. Meanwhile, stainless steel pipes can last for decades. This work evaluates the enviromental and financial performance of evaporators pipes constructed with carbon steel and with 304, 444 and 439 stainless steel. To reach these objectives the methodologies of Life Cycle Assessment (LCA) and the Life Cycle Costing (LCC) were applied, respectively. The water mass evaporated was adopted as function of the systems in LCA study. In the definition of these product systems were adopted the manufacturing of steel and the manufacturing, installation and cleanness of the pipes. Natural gas, electricity and transport had been considered. The evaluation time was thirty years. From the LCA results, there were concluded that the steel carbon pipes presented more enviromental impact performance than 304, 444 and 439 stainless steel pipes, because they emitted more than 4.2 times of carbon dioxide; 2.8 times nitrogen oxides; 3.1 times of particulated materials; 13 times of suspended materials and 4.5 times of total residues. The carbon steel pipes also consumed more than 11 times the sum of all natural resources used (coal, lignite, iron ground, chromium, nickel, molybdenum, manganese; calcite, dolomite; oil and natural gas); 1.8 times more of water and 5 times more of energy. Regards to sulphur oxides emission, the carbon steel pipes emitted the same amount of sulphur oxides as 444 and 439 stainless steel pipes and they emitted half than of 304 stainless steel pipe. In the life cycle costing (LCC) elaboration were applied the cost components: purchase, transportation, installation, substitution, cleanness and the scraps sale. In the financial evaluation, all the costs that have incurred in the period of thirty years have been brought to the present value. As results concluded that 439 and 444 stainless steels presented the best investment options, due to this they have 
presented less costs brought to the present value, in the ratio of 0.76 for the 439 steel pipe; 0.79 for 444 the steel pipe with $1.20 \mathrm{~mm}$ of thickness and 0.93 for 444 steel pipe with $1.50 \mathrm{~mm}$ of thickness. The 304 stainless steel pipes with $1.20 \mathrm{~mm}$ of thickness presented similar financial performance compared to carbon steel pipes; whereas the 304 steel pipes $1.50 \mathrm{~mm}$ of thickness presented costs to 1.19 times higher of the present value. The results also indicate that LCA and LCC methodologies must be used together; therefore, they show that safer enviromental products can become the more interesting investment options.

Keywords: Life cycle assessment. LCA. Life cycle costing. LCC. Pipes. Evaporators. Sugar plant. Carbon steel. Stainless steel. Materials Selection. Sustainability. 


\section{LISTA DE FIGURAS}

Figura 1 - Representação gráfica da primeira definição de ACV em forma de triângulo.

Figura 2 - Incorporação da definição de objetivo e escopo na estrutura técnica da ACV. 38

Figura 3 - Fases de uma ACV ....................................................... 40

Figura 4 - $\quad$ Etapas operacionais de um ICV.............................................. 48

Figura 5 - $\quad$ Elementos da etapa de AICV............................................ 56

Figura 6 - Representação esquemática das etapas que compõem um

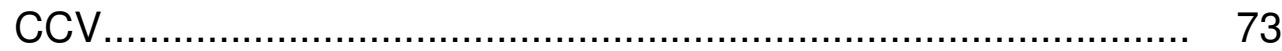

Figura 7 - $\quad$ Diagrama de fluxo da produção de açúcar cru........................... 81

Figura 8 - Fatores que afetam a transferência de calor na evaporação de líquidos.......................................................................... 92

Figura 9 - $\quad$ Corpo de um vaso de um evaporador múltiplo-efeito................... 96

Figura 10 - Disposição dos tubos no espelho da calandra de um evaporador....................................................................... 100

Figura 11 - Distribuição do vapor na calandra........................................... 101

Figura 12 - Circulação do vapor num quádruplo-efeito................................. 102

Figura 13 - Fluxograma de fabricação de tubos........................................... 113

Figura 14 - Fluxograma do sistema de produto dos tubos em aço

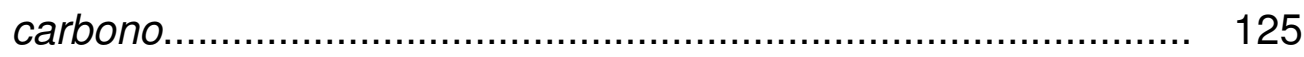

Figura 15 - Fluxograma representativo dos sistemas de produto para os tubos em aços inoxidáveis 304, 444 e 439................................ 128 


\section{LISTA DE TABELAS}

Tabela 1 - Folha de coleta de dados........................................................ 50

Tabela 2 - Exemplo de um ICV de um produto genérico............................. 52

Tabela 3 - Potencial de aquecimento global para alguns gases................. 60

Tabela 4 - Estimativa da vida útil do sistema e da unidade em estudo de

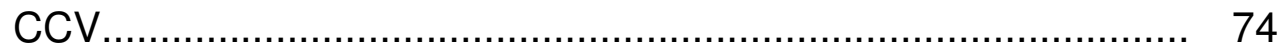

Tabela 5 - Fatores de atualização para cálculo do valor presente de um custo, a diferentes valores de taxas de juros, após um período de 1 a 100 anos..................................................................... 77

Tabela 6 - Fatores de atualização para cálculo do valor presente de um custo, a diferentes valores de taxas de juros, após um período de 1 a 100 anos.

Tabela 7 - Efeito da condutividade do metal no coeficiente total de transmissão de calor - "U”...................................................... 92

Tabela 8 - Faixas de variação do coeficiente total de transmissão de calor.

Tabela 9 - Espessuras dos tubos de diferentes metais para uso em evaporadores.

Tabela 10 - Composição química de aços usados na fabricação de tubos para evaporadores.

Tabela 11 - Parâmetros básicos relacionados aos sistemas de produto 124

Tabela 12 - Composição química dos aços inoxidáveis 430, 444 e 439. 135

Tabela 13 - Teores de Fe, C e S nos minérios usados na fabricação dos aços inoxidáveis 444 e 439

Tabela 14 - Teores dos elementos de liga nas ferro-ligas utilizadas na produção dos aços inoxidáveis 444 e 439

Tabela 15 - Quantidades dos diferentes tipos de aços em bobinas para elaboração dos ICV.

Tabela 16 - Aspectos ambientais relativos ao subsistema limpeza dos tubos para os diferentes sistemas de produto 
Tabela 17 - Subsistema gás natural - contribuição aos ICV dos diferentes sistemas de produto.

Tabela 18 - Subsistema transporte - contribuição aos ICV dos diferentes sistemas de produto

Tabela 19 - Avaliação ambiental dos sistemas de produto tubos em aço carbono e tubos em aços inoxidáveis 304, 444 e 439.

Tabela 20 - Estimativa da vida útil do sistema e da unidade em estudo dos tubos de aço usados nos evaporadores para usinas de açúcar.. 155

Tabela 21 - Especificações dos tubos de aço utilizados neste estudo e os números e massas dos mesmos usados, nos evaporadores para usinas de açúcar

Tabela 22 - Preços dos tubos de aços inoxidáveis 439, 444 e 304 com diferentes espessuras, para uso em evaporadores de usinas de açúcar.

Tabela 23 - Preços para tubos em aço carbono com 2,65 mm de espessura para uso em evaporadores de usina de açúcar.

Tabela 24 - Valores pagos pela compra dos diferentes tipos de tubos para uso em evaporadores de usina de açúcar.

Tabela 25 - Valores pagos pelo transporte dos diferentes tipos de tubos para uso em evaporadores de usina de açúcar.

Tabela 26 - Custo da Instalação e da substituição de tubos em um evaporador de usina de açúcar.

Tabela 27 - Valores calculados para os "Fatores de Juros do Valor Futuro FJVF" e "Fatores e Juros do Valor Presente - FJVP"

Tabela 28 - Custos contábeis e valores relativos à compra dos tubos para evaporadores de usinas de açúcar.

Tabela 29 - Custos contábeis e valores relativos ao transporte dos tubos para evaporadores de usinas de açúcar

Tabela 30 - Custos contábeis e valores presentes relativos à instalação e substituição dos tubos para evaporadores de usinas de açúcar.

Tabela 31 - Despesas com a limpeza dos tubos ao longo do estudo de CCV. 
Tabela 32 - Custos contábeis e valores presentes relativos à venda das sucatas dos tubos para evaporadores de usinas de açúcar

Tabela 33 - Custos contábeis relativos às unidades e componentes de custo em estudo...

Tabela 34 - Valores presentes relativos às unidades e componentes de custo em estudo. 


\section{LISTA DE SIGLAS E ABREVIATURAS}

ABNT Associação Brasileira de Normas Técnicas

ABIQUIM Associação Brasileira da Indústria Química e Produtos Derivados

ACV

Avaliação do Ciclo de Vida

ADA

Avaliação de Desempenho Ambiental

Ad Valorem Valor pago a mais

AICV Avaliação do Impacto do Ciclo de Vida

API American Petroleum Institut

ASTM American Society for Testing and Materials Standards

BSI British Standard Institution

BTU British Thermal Units

Buwal Swiss Agency for Environment, Florest and Landscape

CCV Custeio do Ciclo de Vida

CFC Compostos Fluoretados de Carbono

CSA Canadian Standards Association

COV Compostos Orgânicos Voláteis

Copom Comitê de Política Monetária

COFINS Contribuição para Financiamento da Seguridade Social

DDT Diclorodifeniltricloroetano

DIN Deutsches Institut für Normung

DB Diclorobenzeno

EPA Environmental Protection Agency

EUA Estados Unidos da América

EIA Estudo de Impacto Ambiental

EMAS Eco Management and Audit Scheme

ETH Swiss Federal Institute of Technology

ERW Electric Resistence Welding

$\mathrm{FJVF}_{\mathrm{i}, \mathrm{n}} \quad$ Fator de Juro do Valor Futuro para uma inflação "i" no ano "n"

FJVP $_{\mathrm{i}, \mathrm{n}} \quad$ Fator de Juro do Valor Presente para uma inflação "i" no ano "n"

FEA Forno Elétrico a Arco

FOB Free on Board 
International Organization for Standardization

ICV Inventário do Ciclo de Vida

ICDA International Chromium Development Association

IMOA International Molybdenum Association

IISI International Iron Steel Institute

ISSF International Stainless Steel Forum

\section{IPCC} International Panel for Climate Change

IPCA Índice de Preços ao Consumidor Amplo

Ipea Instituto de Pesquisa Econômica Aplicada

ICMS Imposto de Circulação de Mercadorias e Serviços

IPI Imposto sobre Produtos Industrializados

INOX Aço Inoxidável

$\mathrm{LCl}$

Life Cycle Inventory

LCA

Life Cycle Assesment

MRI

Midwest Research Institute

$\mathrm{NI}$

Nickel Institut

OEDC

Organization for Economic Cooperation and Development

OPEP

Organização dos Países Exportadores de Petróleo

ONU

Organização das Nações Unidas

PIS

Programa de Integração Social

PAG

Potencial de Aquecimento Global

PDCO

Potencial de Depleção da Camada de Ozônio

PTH

Potencial de Toxicidade Humana

PẼ̃

Potencial de Ecotoxicidade Aquática

PEt

Potencial de Ecotoxicidade Terrestre

PAC

Potencial de Acidificação

PEU

Potencial de Eutrofização

Pol

Porcentagem de Extração da Sacarose

RIMA

Relatório de Impacto sobre o Meio Ambiente

REPA

Resource and Environmental Profile Analysis

SETAC

Society of Environmental Toxicology and Chemistry

SGA

Sistema de Gestão Ambiental

SAE

Society of Automotive Engineers 
Selic Sistema Especial de Liquidação e de Custódia

TIG Tungsten Inert Gas

UNEP United Nations Environment Program

u.m. Unidades Monetárias

URSS União das Repúblicas Socialistas Soviéticas

VOD Vacuum Oxygen Descarburation

VP Valor Presente

WMO World Meteorological Organization 


\section{LISTA DE SÍMBOLOS}

BA, WHR, 2B Tipos de acabamentos em aços inoxidáveis

C Condutividade térmica do material que compõe a parede de um tubo

$D_{t}$ Diferença de temperatura entre o vapor e o caldo

e Espessura de parede do tubo

EV Economia de vapor

$\mathrm{h}_{0}$ Coeficiente de transmissão de calor de película do fluído quente à parede de um tubo

$\mathrm{h}_{1} \quad$ Coeficiente de transmissão de calor da parede do tubo ao fluído frio

$\mathrm{h}_{2}$ Coeficiente de transmissão de calor devido à incrustação Taxa de juros anual Número de efeitos de um sistema de evaporação

$\mathrm{N}$ Número total de anos

$\mathrm{N}$ Número de ordem do efeito no sistema de evaporação

n Ano do estudo

$P$ Passo, distância centro a centro entre dois tubos Quantidade de calor transmitida Taxa real de juros Superfície de troca de calor Coeficiente total de transmissão de calor W Peso de vapor 


\section{SUMÁRIO}

1 INTRODUÇÃO.

2.3 A METODOLOGIA DE AVALIAÇÃO DO CICLO DE VIDA - ACV.

2.3.1.1 Definição de objetivo e escopo

2.3.1.1.1 Objetivo do estudo.

2.3.1.1.2 Escopo do estudo.

2.3.2 Análise de Inventário.

2.3.2.1 Preparação para a coleta de dados.

2.3.2.2 Coleta de dados.

2.3.2.2.1 Substituição de dados primários e validação dos dados.

2.3.2.2.2 Relacionando dados ao processo elementar, à unidade funcional e à agregação de dados.

2.3.2.2.3 Refinamento das fronteiras do sistema.

2.3.3 Avaliação do Impacto do Ciclo de Vida (AICV)..................................... 55

2.3.3.1 Características-chave da AICV......................................................... 55

2.3.3.2 Elementos da AICV ................................................................. 56

2.3.3.2.1 Elementos obrigatórios.............................................................. 57

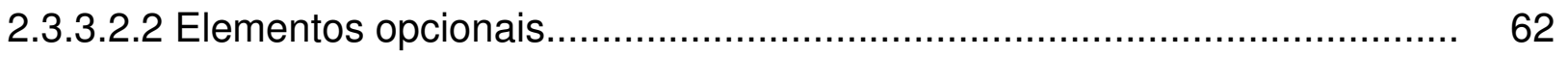

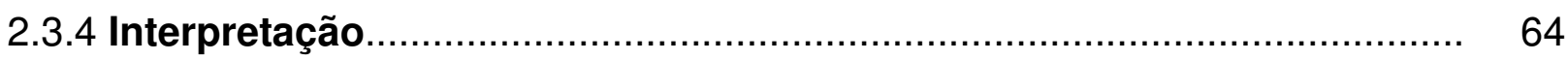

2.3.4.1 Identificação de temas de relevância...................................................... 65

2.3.4.2 Avaliação dos resultados................................................................. 65

2.3.4.3 Conclusões e recomendações............................................................ 66

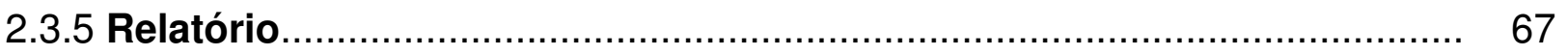


2.3.6 Análise Crítica

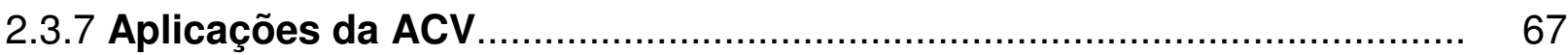

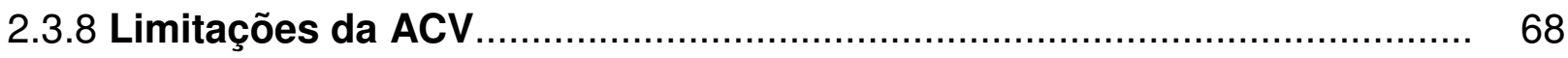

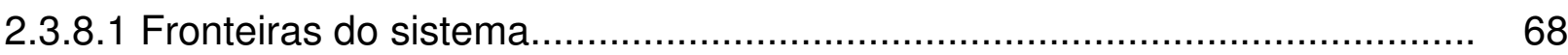

2.3.8.2 Abrangência geográfica................................................................. 69

2.3.8.3 Período de tempo coberto pelo estudo.................................................. 69

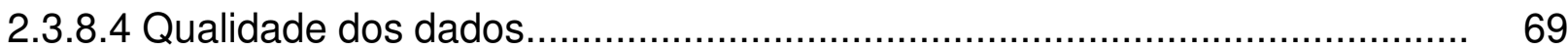

2.3.8.5 Necessidade de combinação com outros instrumentos gerenciais............. 70

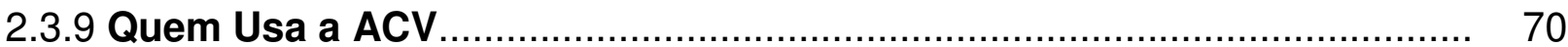

2.4 METODOLOGIA DO CUSTEIO DO CICLO DE VIDA (CCV).......................... 72

2.4.1 A metodologia do CCV...................................................................... 73

2.4.1.1 Definição da unidade a ser estudada..................................................... 73

2.4.1.2 Estimativa do ciclo de vida...................................................................... 74

2.4.1.3 Elaboração do inventário............................................................. $\quad 74$

2.4.1.4 Atualização financeira e composição dos custos totais............................... 75

2.5 FABRICAÇÃO E REFINO DO AÇÚCAR DE CANA...................................... 80

2.5.1 Processo de fabricação do açúcar de cana............................................. 80

2.5.1.1 Extração do caldo...................................................................... 82

2.5.1.2 Purificação do caldo: Clarificação......................................................... 82

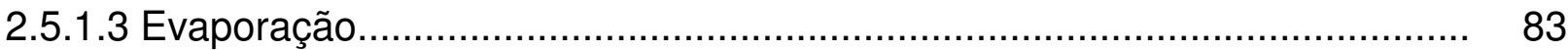

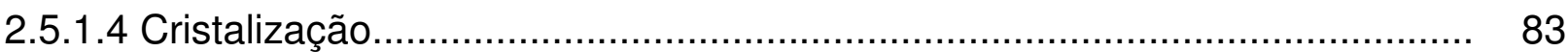

2.5.1.5 Centrifugação ou purga: reebulição dos méis......................................... 84

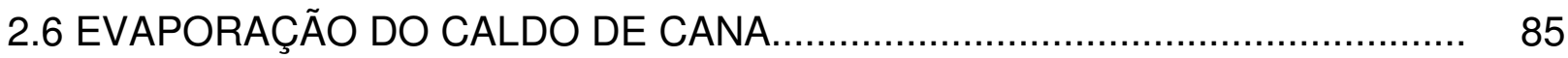

2.6.1 Bases Teóricas da Evaporação do Caldo de Cana.................................. 86

2.6.2 Princípios da Evaporação de Rillieux................................................. 87

2.6.2.1 Primeiro Princípio............................................................................ 8

2.6.2.2 Segundo Princípio............................................................................ 87

2.6.2.3 Terceiro Princípio........................................................................... 88

2.6.3 Termodinâmica aplicada à Evaporação................................................... 89

2.6.3.1 Transmissão de Calor......................................................................... 89 


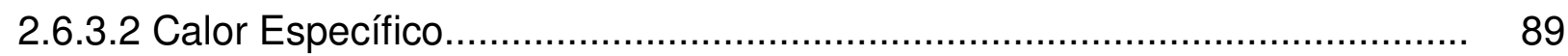

2.6.3.3 Calor Sensível............................................................................... 90

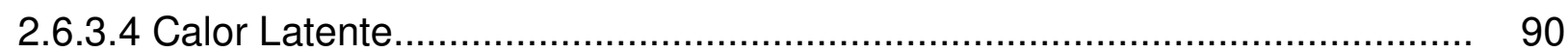

2.6.3.5 Calor total de vaporização.................................................................... 90

2.6.3.6 Transmissão de Calor em um Evaporador............................................... 91

2.6.4 Construção de um Evaporador Múltiplo-Efeito......................................... 94

2.6.4.1 Corpo do Evaporador.................................................................... 94

2.6.4.2 Câmara das evaporações................................................................... 97

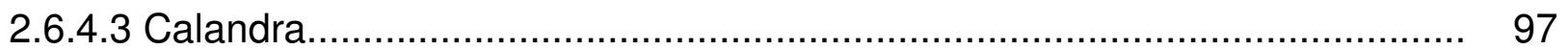

2.6.5 Distribuição do Vapor de Aquecimento nas Calandras......................... 100

2.6.6 Circulação dos vapores em um múltiplo-efeito....................................... 101

2.6.7 Remoção de "Condensados" ............................................................... 102

2.6.8 Remoção de gases Incondensáveis...................................................... 103

2.6.9 Vaso de Segurança.................................................................... 103

2.6.10 Câmara de Caldo e Circulação.......................................................... 104

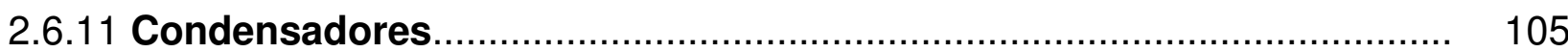

2.7 FORMAÇÃO DE INCRUSTAÇÕES NOS TUBOS DOS EVAPORADORES...... 106

2.7.1 Depósitos externos................................................................................. 106

2.7.2 Depósitos internos e incrustações......................................................... 106

2.7.3 Formação das incrustações........................................................... 107

2.7.4 Limpeza das incrustações................................................................ 109

2.7.4.1 Limpeza Mecânica....................................................................... 109

2.7.4.2 Limpeza Química......................................................................... 110

2.7.4.3 Associação das limpezas mecânica e química......................................... 111

2.8 PRODUÇÃO DE TUBOS PARA EVAPORADORES ...................................... 112

2.9 EVAPORADORES PARA USINA DE AÇÚCAR CONSTRUÍDOS COM TUBOS EM AÇO-CARBONO E AÇOS INOXIDÁVEIS............................................. 116

2.9.1 Projeto de um sistema de evaporação.................................................... 117 


\section{REALIZAÇÃO DOS ESTUdOS DE ACV DE EVAPORADORES PARA}

USINAS DE AÇÚCAR .................................................................................. 119

3. 1 DEFINIÇÃO DE OBJETIVO E ESCOPO............................................... 119

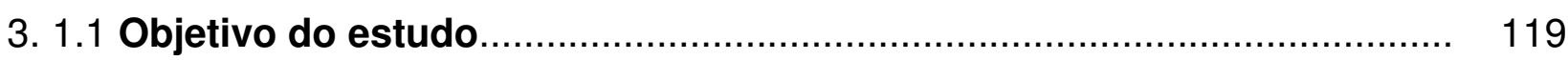

3. 1.2 Escopo do estudo.......................................................................... 120

3. 1.2.1 Função do sistema de produto........................................................ 120

3.1.2.2 Unidade funcional e fluxo de referência.................................................... 121

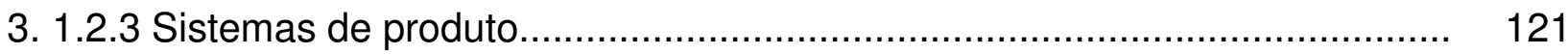

3.1.2.3.1 Sistema de produto tubos em aço carbono........................................... 125

3.1.2.3.2 Sistemas de produto tubos em aço inoxidáveis..................................... 127

3.1.2.4 Fronteiras dos sistemas de produto.................................................... 128

3.1.2.5 Procedimentos de alocação............................................................. 130

3.1.2.6 Requisitos de qualidade dos dados.................................................... 130

3.1.2.7 Análise crítica................................................................................... 131

3.1.2.8 Tipo e formato de relatório.............................................................. 131

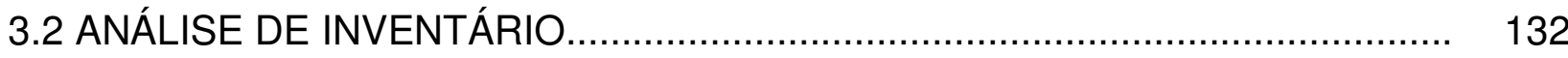

3.2.1 Preparação para coleta de dados........................................................... 132

3.2.2 Coleta de dados............................................................................. 132

3.2.2.1 Subsistema produção de aço carbono................................................... 132

3.2.2.2 Subsistemas produção de aços inoxidáveis............................................ 134

3.2.2.2.1 Considerações........................................................................... 136

3.2.2.3 Subsistema produção dos tubos.......................................................... 137

3.2.2.4 Subsistema instalação dos tubos......................................................... 139

3.2.2.5 Subsistema limpeza dos tubos.......................................................... 139

3.2.2.6 Subsistema gás natural...................................................................... 140

3.2.2.7 Subsistema energia elétrica............................................................. 142

3.2.2.8 Subsistema transporte.................................................................... 143

3.3 AVALIAÇÃO DO IMPACTO DO CICLO DE VIDA........................................ 146 
4.1 DEFINIÇÃO DA UNIDADE E SISTEMA EM ESTUDO.

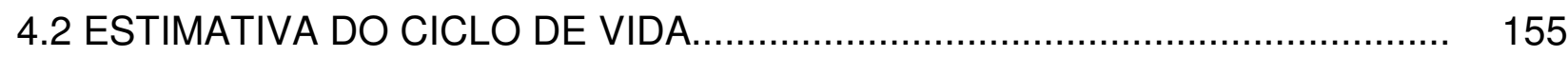

4.2.1 Massa por metro linear dos tubos......................................................... 156

4.2.2 Superfície interna para troca térmica...................................................... 157

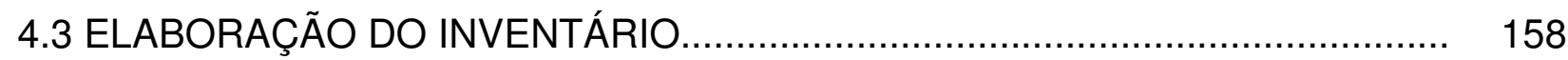

4.3.1 Preços dos tubos para evaporadores.................................................. 159

4.3.2 Transporte dos Tubos....................................................................... 162

4.3.3 Instalação e substituição dos tubos nos evaporadores.......................... 164

4.3.4 Limpeza dos tubos...................................................................... 165

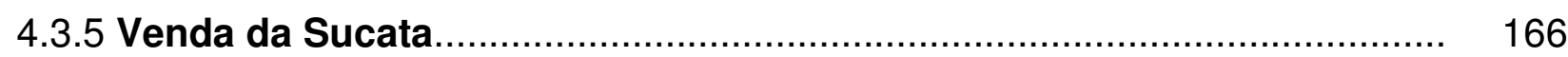

4.4 ATUALIZAÇÃO FINANCEIRA E COMPOSIÇÃO DOS CUSTOS TOTAIS......... 168

4.4.1 Compra dos Tubos................................................................................... 170

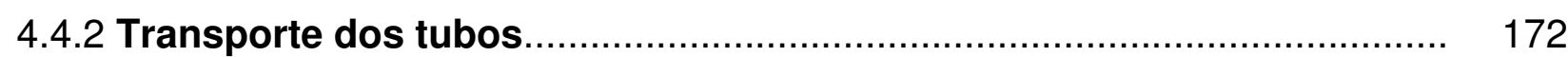

4.4.3 Instalação e reposição dos tubos........................................................... 174

4.4.4.Limpeza dos tubos........................................................................ 176

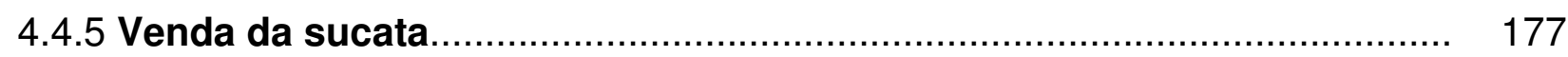

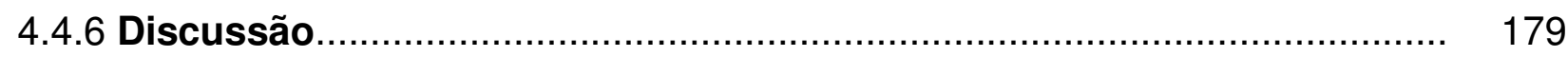

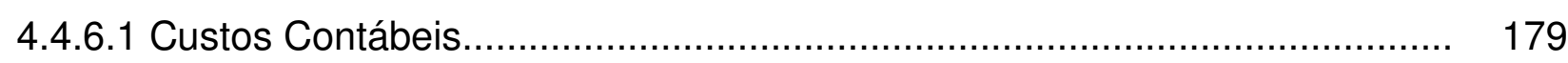

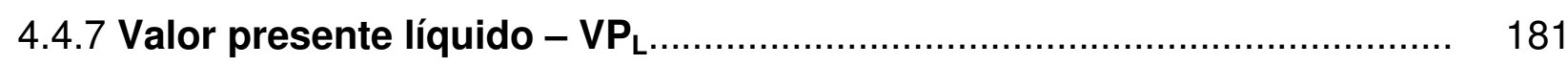

5 CONCLUSÕES..................................................................................... 185

6 SUGESTÕES PARA TRABALHOS FUTUROS............................................ 187

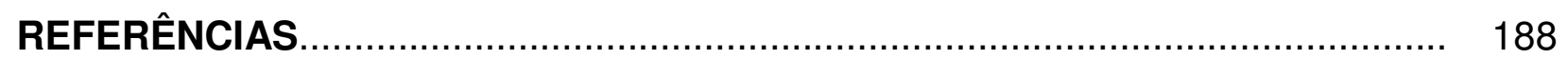


APÊNDICE A - Inventário do ciclo de vida para $1000 \mathrm{~kg}$ de aço carbono em bobina.

APÊNDICE B - Inventário do ciclo de vida para $1000 \mathrm{~kg}$ dos aços 304, 444 e 4: em bobinas.

APÊNDICE C - Inventário do ciclo de vida do sistema de produto de tubos em aço carbono, com $2,65 \mathrm{~mm}$ de espessura.

APÊNDICE D - Inventário do ciclo de vida do sistema de produto de tubos em aço inoxidável 304, com 1,20 mm de espessura.

APÊNDICE E - Inventário do ciclo de vida do sistema de produto de tubos em aço inoxidável 304 , com $1,50 \mathrm{~mm}$ de espessura.

APÊNDICE F - Inventário do ciclo de vida do sistema de produto de tubos em aço inoxidável 444 , com $1,20 \mathrm{~mm}$ de espessura.

APÊNDICE G - Inventário do ciclo de vida do sistema de produto de tubos em aço inoxidável 444, com 1,50 $\mathrm{mm}$ de espessura.

APÊNDICE H - Inventário do ciclo de vida do sistema de produto de tubos em aço inoxidável 439 , com $1,50 \mathrm{~mm}$ de espessura.

APÊNDICE I - Planilha consolidada dos inventários do ciclo de vida dos sistemas de produtos em estudo

ANEXO A - Potenciais de alguns gases para as categorias de impactos mais utilizadas nos estudos de AICV. 


\section{INTRODUÇÃO}

O setor de açúcar e álcool é o setor industrial que mais cresce no Brasil. Corroboram esta afirmativa os seguintes pontos ${ }^{1}$ :

- Em dezembro de 2006 estavam em operação no Brasil trezentas e sessenta e nove usinas de açúcar e álcool;

- em 2007 serão inauguradas dezessete usinas;

- para o período 2008 e 2009 existem vinte e nove projetos em diferentes estágios de execução;

- calcula-se que serão necessárias sessenta e duas novas usinas até 2010 , ou seja, além das já citadas, mais dezesseis usinas precisarão ser construídas;

- com os acordos com a União Européia na Organização Mundial do Comércio, em 2006, o Brasil venderá mais quatro milhões de toneladas de açúcar por ano para aquele continente;

- $44 \%$ do território nacional apresenta médio a alto potencial para o cultivo de cana de açúcar.

- novas variedades de cana de açúcar têm sido desenvolvidas, com a incorporação de resistência a pragas e doenças, a diferentes disponibilidades de água e nutrientes e o aumento do período de plantio e colheita.

Independente deste desenvolvimento, a área industrial produtora de açúcar, um alimento, ainda convive com uma prática industrial ultrapassada, que vem a ser o uso de aço carbono, um material de baixo custo, mas com baixíssima resistência à corrosão. Prova disto é visto nas usinas de açúcar na entressafra, onde é grande a movimentação de mão de obra, tendo em vista a substituição ou reparo de alimentadores de cana, prensas, tanques, tubos, separadores de arraste, tubulações de vapor, condensadores, etc, equipamentos que tem em comum o uso do aço carbono.

Em uma usina de açúcar, como em qualquer indústria, todos os equipamentos são importantes, pois a princípio, podem fazê-la parar por horas e até dias. Nas usinas de açúcar, dois conjuntos de equipamentos merecem atenção especial, o sistema de moagem, com os vários ternos de moendas e o sistema de 
evaporação, onde mais que sessenta por cento da água presente no caldo de cana é evaporada.

No sistema de evaporação, cabe salientar a importância dos tubos de troca térmica, onde acontece o aquecimento do caldo de cana em concentração. Estes tubos, quando em aço carbono, começam a ser substituídos em espaços de tempo muito curtos. Em muitas usinas, é comum a troca parcial de tubos a partir da segunda safra de uso. Enquanto isto, a Usina Pumaty S. A., no Nordeste Brasileiro, opera um evaporador com tubos em aço inoxidável 304 há trinta e três safras e estes tubos apresentam-se muito bem conservados e em pleno uso.

A década de sessenta marcou o início de uma conscientização ambiental em todo o mundo, tendo acontecido inúmeros esforços de governos e entidades, públicas e privadas, nesse sentido. Dentre estes trabalhos, a metodologia de avaliação do ciclo de vida $(A C V)^{2}$, uma ferramenta de gestão ambiental que trata com objetividade questões ambientais complexas, tais como a gestão de recursos naturais, estudos comparativos entre produtos e serviços, otimização de sistemas de reciclagem, entre outros. Esta técnica, em síntese, contabiliza todas as entradas de matérias-primas e energia, as saídas de produtos, co-produtos e emissões, bem como os impactos ambientais ocasionados pelo sistema de produção, ao longo de todo o ciclo de vida, ou seja, desde a prospecção das matérias-primas na natureza, beneficiamento, produção, transporte, uso, descarte, reciclagem e destinação final.

A metodologia de avaliação de ciclo de vida tem sido usada intensamente em todo o mundo moderno. Países como Estados Unidos, Japão, Alemanha, França, Canadá, Áustria, Holanda, Suíça, Suécia, Noruega, Finlândia; instituições internacionais como Society of Environmental Toxicology and Chemistry (SETAC), Organization for Economic Cooperation and Development (OECD), United Nations Environment Program (UNEP), Environmental Protection Agency (EPA) e empresas como Hewlett Packard, Eastman-Kodak, Procter \& Gamble, General Eletric, Dow Chemical, Volvo, General Motors, Chrysler-Mercedez Bens, entre muitas outras fazem uso contínuo desta metodologia para todas as suas decisões que envolvam questões ambientais.

No Brasil a avaliação do ciclo de vida ainda é pouco utilizada fora do meio acadêmico. Estima-se, no entanto, que devido à crescente participação do Brasil no mercado global, as iniciativas nessa área se multiplicarão. 
O mundo moderno também tem desenvolvido ferramentas econômicofinanceiras para ajudar o empresário e o homem público em decisões que envolvam estas questões. O custeio do ciclo de vida (CCV) é uma delas. O custeio do ciclo de vida é uma metodologia para a seleção de materiais ou produtos, que contabiliza os custos totais do sistema em análise, desde a sua concepção, até o fim da sua vida útil, ou seja, ao longo do seu ciclo de vida ${ }^{3}$. Este sistema pode ser uma planta petroquímica, uma ponte, a carroceria de um ônibus, uma usina de açúcar ou apenas um evaporador.

O que diferencia a aplicação desta metodologia com relação a outros estudos de performance é que neste são levados em conta, além dos custos de investimentos, todos os demais custos existentes durante as diferentes fases do ciclo de vida do sistema em análise, ou seja: produção, transporte, instalação, operação, manutenções programadas ou corretivas, desativação, reposição, reuso ou reciclagem dos materiais residuais ao fim da vida útil da unidade, valores obtidos pela venda destes materiais, bem como o que se deixou de ganhar em termos financeiros ou dano ao público usuário pelas horas não trabalhadas.

O somatório de todos estes custos permitirá ao interessado selecionar a melhor alternativa financeira.

A integração das metodologias de ACV e de CCV permite ao pesquisador, ao engenheiro, ao empresário e ao homem público desenvolver produtos e serviços que contemplem, simultaneamente, a redução de impactos ambientais e de custos financeiros. 


\section{REVISÃO BIBLIOGRÁFICA}

\subsection{O SETOR INDUSTRIAL E O MEIO AMBIENTE.}

As indústrias tem sido altamente responsáveis pela degradação do meio ambiente em todo o mundo, contaminando o ar, a água e o solo, contribuindo para a disseminação de inúmeras doenças, além de consumir recursos naturais não renováveis com reduzido nível de controle, muitas vezes.

Independente das dificuldades e eventuais retrocessos, as organizações industriais e as entidades representativas, pressionadas pelos governos e pela sociedade, têm procurado reduzir seus impactos ambientais e assumir as responsabilidades ambientais dos seus processos produtivos. Parte destas organizações tem-se preocupado desde a obtenção das matérias-primas, passando pelo beneficiamento, transporte, processamento, uso, reúso, reciclagem, até a disposição final dos resíduos, dentro do conceito "do berço ao túmulo".

Dentre as inúmeras ações tomadas pelo setor industrial, cabe destacar as da "Câmara de Comércio Internacional", que congrega boa parte do setor industrial mundial, que iniciou um processo de discussão de estruturas lógicas de sistematização da gestão ambiental, compatibilizando interesses de qualidade e produtividade. Dessa oportuna iniciativa, surgiu na década de 90 o conceito de "Sistema de Gestão Ambiental (SGA)", que fixa as especificações para a certificação e avaliação de um sistema de gestão ambiental de uma organização ${ }^{5}$.

Esses estudos foram formalizados pela British Standard Institution (BSI) na Norma BS 7.750 - Specification for Environmental Management System, em 1994, dentro da seguinte seqüência:

- Criação do Eco Management and Audit Scheme (EMAS), que passou a ser a regulamentação ambiental da Comunidade Européia;

- A BSI, com o apoio do Environmental and Pollution Standards Policy Comittee, iniciaram estudos visando o refinamento desta Norma;

- Em junho de 1991 foi emitido um rascunho da Norma para avaliação pública;

- Em março de 1992 foi feita a publicação oficial; 
- Corrigidas algumas imperfeições, a Norma BS 7750 foi reeditada em janeiro de 1994.

Em paralelo, em 1991 foi organizada a 2ª Conferência Mundial da Indústria, na Holanda, com o objetivo de organizar as opiniões do setor industrial. ${ }^{5}$

Essa conferência deu origem à "Carta Empresarial para o Desenvolvimento Sustentável", também conhecida como "Carta de Roterdã", documento que tem servido de base para a elaboração das políticas ambientais adotadas por muitas organizações empresariais em todo o mundo.

Esse documento foi apresentado na Conferência da ONU - ECO 92, realizada no Rio de Janeiro no ano seguinte. ${ }^{4,5}$

No Brasil, cabe citar a excelente atuação da Associação Brasileira da Indústria Química e Produtos Derivados (ABIQUIM), que em 1992 adotou os princípios do "Responsable Care", um conjunto de conceitos e recomendações desenvolvidos no Canadá e que tem sido adotados pelas indústrias químicas em todo o mundo desenvolvido.

Tendo em vista a uma série de impactos ambientais que envolveram interesses internacionais e porque a BS 7750 não havia alcançado uma repercussão internacional como esperado inicialmente junto a International Organization for Standardization (ISO), criou em março de 1993 um Comitê Técnico (TC-207), para a elaboração de um conjunto de normas sobre gestão ambiental. O TC-207, sediado no Canadá, e coordenando os trabalhos de seis Sub-Comitês (SC) e um Grupo de Trabalho (WG), localizados na Inglaterra, Holanda, Austrália, Estados Unidos, França, Noruega e Alemanha e com a participação dos 110 organismos nacionais regulatórios que o compunham, dos quais a Associação Brasileira de Normas Técnicas (ABNT) é a representante do Brasil, elaborou as cinco primeiras Normas da série ISO $14000 .^{4}$

Em reunião ocorrida em agosto de 1996, no Rio de Janeiro, a ISO e países membros aprovaram as seguintes normas: ${ }^{4}$

- ISO 14001;

- ISO 14004;

- ISO 14010;

- ISO 14011;

- ISO 14012. 
As quatro Normas da série ISO 14040 relativas a ACV, uma das ferramentas de gestão ambiental formalizadas pela ISO para as organizações empresariais, foram aprovadas a partir de 1997, na seguinte seqüência: ${ }^{6}$

- ISO 14040 - Environmental management - Life cycle assesment (LCA) Principles and framework (1997); ${ }^{7}$

- ISO 14041 - Environmental management - Life cycle assesment (LCA) - Goal and scope definition and inventory analysis (1998); ${ }^{8}$

- ISO 14042 - Environmental management - Life cycle assesment (LCA) - Life cycle impact assessment $(2000){ }^{9}$

- ISO 14043 - Environmental management - Life cycle assesment (LCA) - Life cycle interpretation (2000). ${ }^{10}$

Essa série de Normas relativas a ACV contém três relatórios técnicos que as exemplificam, a saber:

- ISO TR 14047 - Ilustratives examples on how to apply ISO $14042 ;^{11}$

- ISO TR 14048 - Environmental management - Life cycle assesment (LCA) data documentation format ${ }^{12}$;

- ISO TR 14049 - Environmental management - Life cycle assesment (LCA) Examples for the application of ISO 14041 to goal scope definition and inventory analysis $^{13}$.

Com a emissão da série ISO 14000, em especial a ISO 14001, a Norma BS 7750 foi desativada, em janeiro de 1997.

\subsection{AS ORIGENS DA "AVALIAÇÃO DO CICLO DE VIDA (ACV)"}

A primeira Norma ISO referente à "avaliação do ciclo de vida" foi aprovada em 1997. Independente disso, o conceito de "ciclo de vida" começou a ser utilizado com mais de 20 anos de antecedência.

Uma das primeiras publicações foi a de Harold Smith, em 1963, na "World Energy Conference". Este trabalho apresentou o cálculo das necessidades de energia para a fabricação de produtos químicos e marcou o início do uso deste tipo de análise para os sistemas de produção, na sua maioria. ${ }^{14}$ 
Em 1969, "The Coca-Cola Company" contratou o Midwest Research Institute (MRI) para fazer um estudo comparativo entre diferentes tipos de embalagens de refrigerante e a avaliação de qual deles apresentava o melhor desempenho ambiental com relação à conservação de recursos naturais e a emissão de resíduos. $^{2,18}$

Esse estudo tornou-se conhecido como Resource and Environmental Profile Analysis (REPA) e foi aprimorado em 1974, quando o MRI foi contratado pela Environmental Protection Agency para a realização de um trabalho semelhante envolvendo diferentes fontes de energia.

Os estudos desenvolvidos pelo MRI são referenciados como a origem do que hoje conceituamos como "avaliação do ciclo de vida" (Life Cycle Assessment), ou seja, desde a extração da matéria-prima, até a disponibilização final dos seus resíduos, passando pelas fases de produção, uso, reciclagem, etc.

Os grandes interesses despertados pelos estudos chamados de REPA levaram os pesquisadores do MRI a criarem a "Franklin Associates", que se tornou um dos maiores escritórios de consultoria em ACV dos EUA.

As questões ambientais em torno da produção e descarte final de embalagens para bebidas continuaram a ter grande importância no desenvolvimento do método de análise conhecido como ACV. Em 1985, a Comunidade Européia introduziu a "Liquid Food Container Directive" que exigiu dos países membros um controle do consumo de energia e matérias-primas, assim como da geração de resíduos sólidos, na produção e descarte final de embalagens para bebidas e alimentos líquidos. ${ }^{4,16}$

Um grande número de consultores e pesquisadores americanos e europeus, bem como algumas instituições de pesquisa continuaram a estudar a metodologia REPA, agregando novos conceitos relacionados à avaliação de impactos ambientais, gerenciamento de resíduos e inclusão de parâmetros de referência para a saúde humana. ${ }^{14}$

Com esta inspiração, o Ministério de Meio-Ambiente Suíço (BUS) contratou um estudo sobre materiais de embalagem que despertou grande atenção internacional, por introduzir um sistema de ponderação baseado em padrões de saúde para agregar dados sobre impacto ambiental. Através deste trabalho foram tornados públicos o procedimento de valoração utilizado e a extensiva base de dados do Laboratório Suíço de Pesquisa de Materiais, que tem sido utilizada em 
muitos outros estudos semelhantes. Em 1991 estes dados foram atualizados e publicados por Habersatter e Widmer e desenvolvida nova versão para o primeiro software (Ökobase I e II) ${ }^{17}$.

Paralelamente aos estudos de caráter quantitativo, foi desenvolvida na Alemanha uma metodologia mais ampla e qualitativa denominada PLA - ProduktLinien-Analyse (Projektgruppe Ökologische Wirtschaft, 1985), que inclui a definição de objetivo e escopo e uma escolha de parâmetros, incluindo aspectos sociais e econômicos $^{17}$.

Nos EUA, a Franklin Associates e Batelle tornou-se uma referência nos estudos de ACV, enquanto que na Europa os trabalhos realizados por lan Boustead no Reino Unido, por Sundström na Suécia, Batelle na Alemanha e pelo Eidgenössische Materialprüfrungs - und Versuchsanstalt für Industrie (EMPA) na Suíça são os mais citados. Mais recentemente, a Universidade de Leiden na Suíça, a empresa francesa Ecobilan e o grupo de trabalho sobre ACV do "Nordic Council of Ministers" tem contribuído significativamente para o desenvolvimento desta ferramenta de gestão ambiental e gerado as melhores bases de dados sobre 0 assunto. Entretanto, estas informações sempre estiveram disponíveis entre as empresas e consultorias, não tendo sido gerado uma base de dados robusta e disponível para todo o público usuário. Além disso, a falta de uma padronização dos procedimentos utilizados levou a resultados controversos e, muitas vezes, tendenciosos, que quase chegaram a comprometer a importância dessa ferramenta de apoio a gestão ambiental ${ }^{16,17}$.

A primeira entidade que se preocupou com a padronização dos termos, critérios e procedimentos relativos a ACV foi a SETAC e a "SETAC Foundation for Environmental Education Inc", que em março de 1993 publicou "A Conceptual Framework for Life - Cycle Impact Assessment" ${ }^{18}$. Esse trabalho foi de importância fundamental para a ACV e serviu de inspiração para a elaboração das Normas ISO sobre o assunto. ${ }^{4}$

Segundo LEVY $^{19}$ (1995), os estudos realizados até final da década de 80 usavam uma metodologia conhecida como "Life Cycle Analyis", que envolvia apenas os aspectos quantitativos relativos à mensuração de recursos, uso de energia, produção e geração de resíduos. Foi então que a SETAC utilizou pela primeira vez o termo "Life Cycle Assessment (LCA)", que relacionou a etapa de inventário já existente (Life Cycle Inventory - LCI) a duas novas etapas: Avaliação de Impactos 
(Life Cycle Impact Assessment - LCIA) e Avaliação de Melhorias (Improvement Analysis).

A Figura 1 mostra a inter-relação entre as etapas que compõe a ACV, conforme a primeira definição da SETAC.

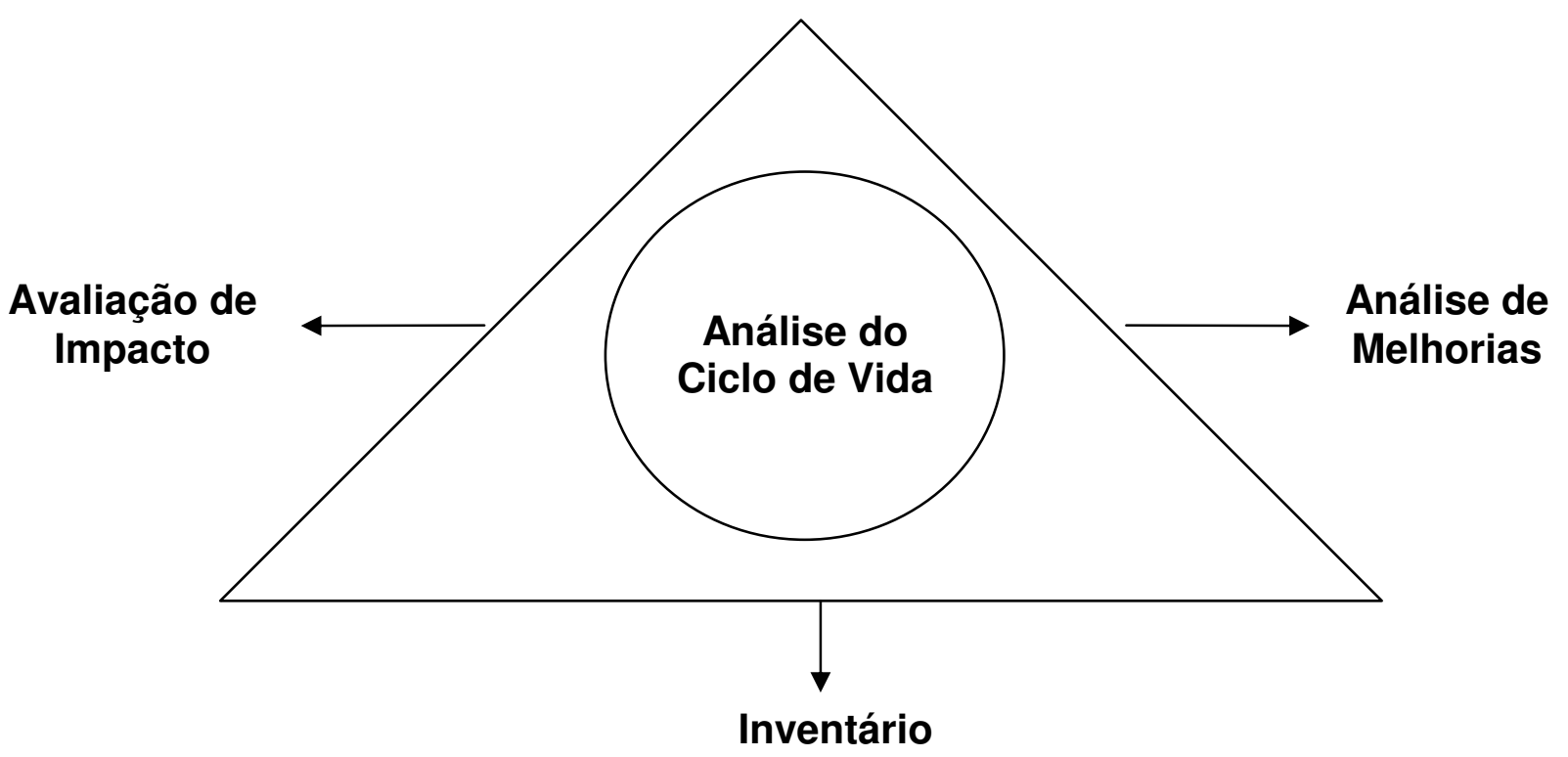

Figura 1 - Representação gráfica da primeira definição de ACV em forma de triângulo Fonte: FAVA, J. et al ${ }^{14}$

Pouco tempo mais tarde foi incluído na metodologia da ACV uma parte inicial de definição de objetivo, escopo e sistema estudado.

A Figura 2 mostra a representação expandida da ACV, segundo a SETAC ${ }^{18}$. 


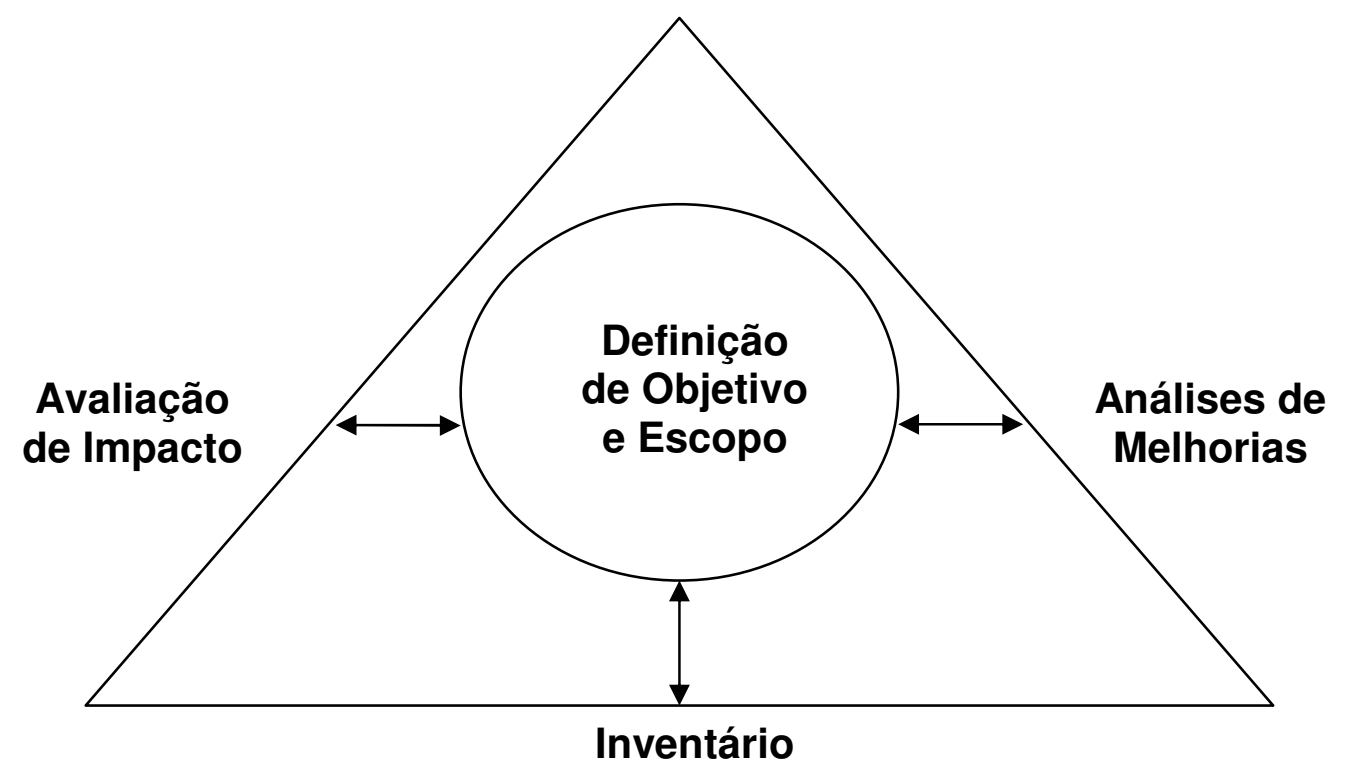

Figura 2 - Incorporação da definição de objetivo e escopo na estrutura técnica da ACV Fonte: SETAC (1993) ${ }^{\text {18 }}$

Afora o documento publicado sobre a ACV em 1993, a SETAC promoveu inúmeros workshops nos EUA e Europa na década de 90, reunindo os maiores especialistas da área, a partir dos quais foram gerados documentos com a finalidade de estabelecer procedimentos formais para a realização de ACVs e evidenciar os pontos que merecem maior atenção ao longo do estudo ${ }^{14}$.

Além da SETAC, vários especialistas como Vigon (EUA), Heijung (Holanda), Boustead (Inglaterra); a firma inglesa Sustent Ability Ltd, da Environment Protection Agency, da Canadian Standards Association (CSA) entre outros, contribuíram para o desenvolvimento desta metodologia e fazerem-na chegar ao estágio atual das Normas ISO da Série $14040^{20}$. 


\subsection{A METODOLOGIA DE AVALIAÇÃO DO CICLO DE VIDA}

As Normas ISO 14040, 14041, 14042 e 14043 apresentadas no item 2.1, página 32, foram traduzidas e adaptadas às terminologias brasileiras pela ABNT, representante do Brasil na ISO. Dessa forma, temos hoje no Brasil as Normas citadas adiante, correspondentes às homólogas Normas ISO:

- NBR ISO 14040 - Gestão Ambiental - Avaliação do Ciclo de Vida - Princípios e estrutura (NOV 2001) $)^{21}$;

- ABNT NBR ISO 14041 - Gestão Ambiental - Definição de objetivo e escopo e análise de inventário (JUN 2004) ${ }^{22}$;

- ABNT NBR ISO 14042 - Gestão Ambiental - Avaliação do Impacto do Ciclo de Vida (JUN 2004) ${ }^{23}$.

- ABNT NBR ISO 14043 - Gestão Ambiental - Interpretação do Ciclo de Vida $(2005)^{24}$.

Os relatórios técnicos que exemplificam estas Normas, ISO TR $14047^{14}$, $14048^{12}$ e $14049^{13}$ ainda não foram traduzidos.

Nessas Normas encontram-se descritos os princípios e as estruturas necessárias para a realização de um estudo de ACV. Este material é complementado pelos trabalhos desenvolvidos por membros da comunidade científica das principais Universidades Brasileiras, que vem desenvolvendo estudos, tanto de aplicação, aprimoramento e criação de banco de dados compatíveis às condições brasileiras.

\subsubsection{Fases de uma ACV}

Segundo a Norma NBR ISO $14040^{21}$, um estudo de ACV é composto por quatro fases:

- Definição de objetivo e escopo;

- Análise de inventário;

- Avaliação de impacto; e, 
- Interpretação.

Essas fases relacionam-se às demais de forma iterativa, tal como é representado na Figura 3, a seguir:

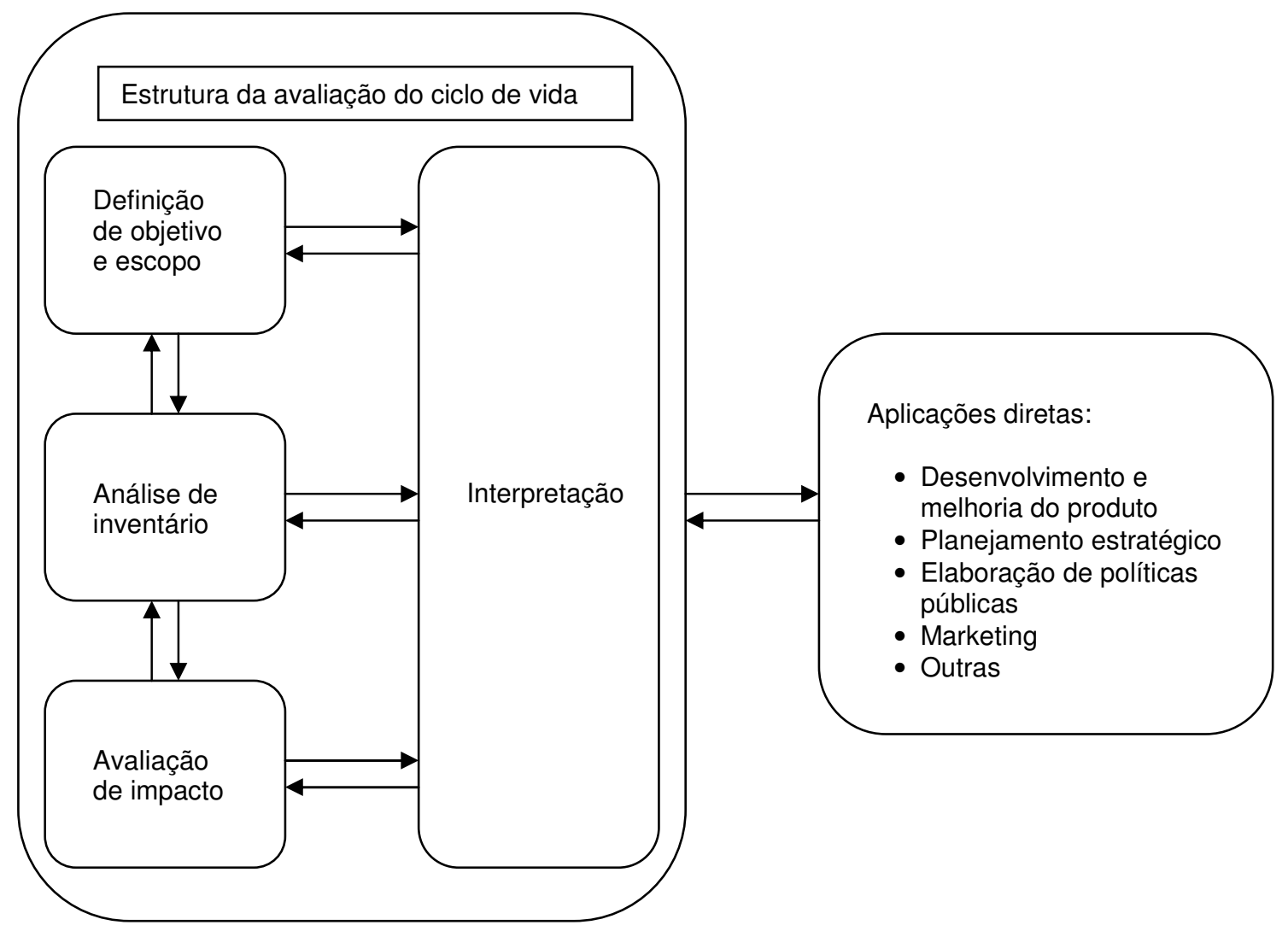

Figura 3 - Fases de uma ACV

Fonte: Figura 1 da Norma NBR ISO 14040: $2001^{21}$.

É importante salientar o caráter iterativo de execução da ACV, ou seja, conforme vai se progredindo no estudo, é possível voltar a algum ponto anterior para verificar se os dados coletados, a avaliação de impacto e, ou, a interpretação atende ao estabelecido na definição de objetivo e escopo. 


\subsubsection{Definição de objetivo e escopo}

Esta é uma etapa crítica para o sucesso de uma $A C V$, pois norteará a execução de todo o estudo.

\subsection{Objetivo do estudo}

Na definição do objetivo de um estudo de ACV devem-se declarar claramente a aplicação pretendida, as razões para a sua aplicação, bem como para quem se pretende comunicar os resultados do estudo e o processo de revisão crítica que se pretende adotar.

$\mathrm{Na}$ definição do objetivo determina-se também o nível de sofisticação do estudo e as exigências do relatório final, de forma a melhor atender o público-alvo.

\subsection{Escopo do estudo}

De uma forma simplificada a norma NBR ISO $14040^{21}$ deixa claro que na definição do escopo devem ser estabelecidas as três dimensões do estudo da ACV, ou seja:

- A extensão da ACV - onde iniciar e parar o estudo;

- A largura da ACV - quantos e quais subsistemas devem ser incluídos; e,

- A profundidade da ACV - o nível de detalhamento do estudo.

Para que as dimensões do estudo de ACV sejam adequadamente atendidas, devem ser considerados os seguintes elementos:

a) as funções do sistema de produto ou dos sistemas, no caso de estudos comparativos, ou seja, a que se presta o produto em análise e qual é a função a que ele se destina; 
b) sistema de produto: consiste no conjunto de unidades de processo, conectadas material ou energicamente, que realiza uma ou mais funções previamente definidas;

c) a unidade funcional: a definição da unidade funcional é a base de um estudo de $\mathrm{ACV}$, porque provê uma medida de desempenho ou de referência para a qual as quantificações das entradas e saídas do sistema em termos ambientais serão normalizadas. Todos os dados coletados na fase de análise de inventário serão retratados à unidade funcional. Esta medida de desempenho é necessária para assegurar a comparabilidade de resultados da ACV, principalmente quando compara-se produtos que desempenham a mesma função. A unidade funcional de um sistema precisa ser claramente definida e mensurável. O resultado da medição do desempenho é o fluxo de referência. Como exemplo de unidade funcional de um sistema, pode-se citar um quilo de água evaporada em um evaporador de caldo de cana de açúcar.

d) As fronteiras do sistema: são as bases para a delimitação das dimensões da ACV. De acordo com Tillman e Baumann, apud Ribeiro ${ }^{26}$, elas são:

- Fronteiras em relação ao sistema natural: são os limites que indicam onde o ciclo de vida se inicia e termina, em relação ao meio natural;

- Fronteiras em relação a outros sistemas: em geral, cada sistema de produto tem associado uma rede de outros sistemas, como produção de insumos, subprodutos gerados, etc. Deve-se delimitar dentro desta rede quais processos serão ou não estudados, sob pena de estarmos tentando abranger um universo demasiadamente amplo;

- Fronteiras geográficas: definem onde cada processo será considerado e como realizado, uma vez que cada localidade possui características que podem fazer o resultado tornar-se inadequado;

- Fronteira temporal: considera o momento para o qual os dados levantados terão validade, ou seja, se será estudada uma situação atual, passada ou futura;

- Fronteiras tecnológicas: representam o nível tecnológico ao qual os dados do estudo correspondem; 
- Fronteiras de bens de capital: determinam se serão incluídos ou não no estudo as infra-estruturas necessárias para a realização dos processos (edifícios das fábricas, estradas, etc.).

Para a adequada fixação destas fronteiras, torna-se necessário uma ampla avaliação do sistema em estudo. Para que esta atividade seja realizada eficientemente, do ponto de vista de custo e tempo recomenda-se à elaboração de fluxogramas englobando os diferentes sistemas. Desta forma serão estabelecidas as fronteiras do (s) sistema (s), tanto com o meio ambiente como entre si. A comunicação entre os sistemas é feita através de correntes de materiais por eles processados. A comunicação entre os sistemas e o meio ambiente é conduzida pelas correntes elementares de matéria e energia;

e) Procedimentos de alocação de fluxos e liberações: a maioria dos processos industriais utiliza fluxos simples de materiais ou de energia, fabrica mais de um produto e recicla ou descarta produtos intermediários. Desta forma, os fluxos de materiais e energia, bem como as liberações ao meio ambiente devem ser alocadas aos produtos fabricados, de forma a distribuir as contribuições aos impactos ambientais por estes resultados do sistema ${ }^{27}$. Segundo a ABNT NBR ISO $14041^{22}$, sempre que possível, é recomendável que a alocação seja evitada, quer seja pela divisão do processo em dois ou mais sub-processos, ou pela ampliação do sistema de produto de forma a englobar as funções adicionais relativas aos co-produtos. Quando a alocação não puder ser evitada, deverão ser usados os critérios de alocação.

Dentre estes, o critério mássico é o de uso mais freqüente, já que a ACV é uma metodologia que se baseia na medição de parâmetros físicos. Neste critério, todos os fluxos que contribuem para os impactos ambientais serão repartidos entre os produtos fabricados na unidade de processo, segundo o porcentual mássico de cada um. Quando a relação física não puder ser estabelecida ou utilizada como a única base para a alocação, os impactos ambientais podem ser alocados entre os co-produtos, em proporção ao valor econômico dos mesmos. Estes critérios de alocação também se aplicam a situações de reutilização e reciclagem de materiais e energia.

f) Tipos (categorias) de impactos ambientais, metodologias de classificação, caracterização, ponderação e interpretação ${ }^{26}$. Após a elaboração do inventário do ciclo de vida do sistema em estudo é necessário que sejam estabelecidos 
critérios de avaliação dos impactos ambientais, o que é realizado através da seleção e definição das categorias ambientais, que serão consideradas na etapa de avaliação de impacto, e que devem estar em consonância com as preocupações ambientais identificadas anteriormente no objetivo e no escopo da ACV. Categorias de impacto é a denominação genérica das classes de problemas ambientais que serão consideradas nos estudos. As categorias de impacto ou problemas ambientais mais utilizadas são, segundo $\mathrm{CHEHEBE}^{2}$ :

- Exaustão de recursos não renováveis;

- Aquecimento global;

- Redução da camada de ozônio;

- Toxicidade humana;

- Ecotoxicidade;

- Acidificação;

- Oxidantes fotoquímicos;

- Nutrificação e eutrofização.

Selecionadas e definidas as categorias de impacto, passa-se à etapa de classificação, onde os dados do inventário são classificados e agrupados nas diversas categorias de impacto selecionadas anteriormente.

A caracterização é a etapa em que se coloca em uma mesma base os diferentes parâmetros que contribuem para uma mesma categoria de impacto ambiental, considerando o efeito relativo de cada um.

A ponderação é a etapa na qual as diferentes categorias de impacto ambiental são somadas entre si, de acordo com uma escala de importância para o meio ambiente, previamente definida e de consenso científico internacional, buscando-se um indicador único de desempenho ambiental para o produto ou serviço.

Para finalizar, na fase de interpretação, as constatações da análise de inventário e da avaliação de impacto são relacionadas de forma consistente ao objetivo e ao escopo do estudo, visando alcançar conclusões e recomendações.

Esta fase pode envolver a repetição da análise crítica e da revisão do escopo da ACV, já que à medida que informações adicionais forem coletadas, o sistema estudado passa a ser mais bem conhecido. 
Para avaliar a influência de dados duvidosos ou falhos, devem ser realizadas análises de sensibilidade. Para tanto, são feitas simulações variandose a ordem de grandeza do dado suspeito e quantificando a significância desta alteração nos resultados do inventário, elaborado com base nesses novos cenários.

Nota: Este item será analisado com mais detalhes em 2.3.4.2, página 65.

g) Requisitos de qualidade dos dados: as Normas NBR ISO 14040:2001 ${ }^{21}$ e ABNT NBR ISO 14041:2004 22 estabelecem que os requisitos de qualidade dos dados devem ser definidos para possibilitar que os objetivos e o escopo do estudo da ACV sejam alcançados. Estas Normas estabelecem também que quando um estudo é usado para apoiar uma afirmação comparativa que será disponibilizada ao público, convém que os requisitos de qualidade dos dados abordem:

- Período de tempo coberto;

- Área geográfica coberta;

- Tecnologias envolvidas no estudo;

- Precisão, completeza e representatividade dos dados;

- Consistência e reprodutibilidade dos métodos usados ao longo da ACV;

- Fonte dos dados e sua representatividade;

- Incerteza da informação.

h) Análise de sensibilidade: os objetivos da análise de sensibilidade são:

- Revisão dos resultados da análise de sensibilidade e análise de incerteza que foram realizadas nas diferentes etapas do estudo;

- Avaliação se as questões ambientais significantes, previamente identificadas como as mais importantes, estão excedendo as variações aceitáveis estabelecidas no objetivo e escopo do estudo.

$\mathrm{CHEHEBE}^{2}$, de forma complementar, ressalta que os efeitos cumulativos das variações na qualidade dos dados, as estimativas adotadas, hipóteses assumidas e as limitações impostas ao próprio modelo introduzem incertezas nos resultados da $\mathrm{ACV}$, sendo necessário checar a confiabilidade dos dados.

A análise de sensibilidade pode ser conduzida através da mudança de parâmetros-chaves do ciclo de vida estudado, recalculando-se o inventário e comparando-se o resultado com a situação em referência. Um método prático de realizar essa análise é a construção de cenários envolvendo situações melhores 
e piores. Outra possibilidade é a variação para mais ou para menos nos valores de entrada da variável selecionada para análise;

i) Comparações entre sistemas: em estudos de ACV que tratam de comparações entre sistemas, devem ser usadas a mesma unidade funcional e considerações metodológicas equivalentes, tais como desempenho, fronteiras dos sistemas, qualidade dos dados, procedimentos de alocação, regras de decisão na avaliação de entradas e saídas e avaliação de impactos. Quaisquer diferenças entre sistemas com respeito a estes parâmetros devem ser identificadas e relatadas. No caso de afirmações comparativas disponibilizadas ao público, esta avaliação deve ser conduzida de acordo com o processo de análise crítica apresentado na ABNT NBR ISO 14040:2001 ${ }^{21}$. Outro requisito para afirmações comparativas disponibilizadas ao público é que deve ser realizada uma avaliação de impacto ambiental.

j) Análise crítica: segundo a ABNT NBR ISO 14040:2001 ${ }^{21}$, análise crítica é uma técnica para verificar se um estudo de ACV satisfez os requisitos desta Norma quanto à metodologia, aos dados e ao relatório. Quando se pretende utilizar o estudo para fazer uma afirmação comparativa disponibilizada ao público, ela deve ser realizada conforme apresentada na ABNT NBR ISO 14040:200121. Quando a análise crítica for utilizada, deve ser definido no escopo do estudo como ela será conduzida, bem como quem a conduzirá.

k) Tipo e formato do relatório a ser disponibilizado ao público: segundo a ABNT NBR ISO $14040: 2001^{21}$, os resultados da ACV devem ser relatados ao públicoalvo ou ao cliente de forma fiel, clara, completa, precisa e exata. O tipo e o formato do relatório devem ser definidos na fase de escopo do estudo.

Cabe salientar que o escopo deve ser suficientemente bem definido para assegurar que a extensão, a profundidade e o grau de detalhe do estudo sejam compatíveis e suficientes para atender o objetivo do estudo de ACV. Cabe também lembrar que a ACV é uma técnica iterativa. Portanto, o escopo pode necessitar de modificação enquanto o estudo estiver sendo conduzido, tendo em vista às novas informações que estão sendo coletadas. 


\subsubsection{Análise de Inventário}

A análise de inventário do ciclo de vida é a segunda fase de uma ACV. Esta fase contempla o levantamento, a compilação e a quantificação das entradas e saídas de um dado sistema de produto em termos de recursos naturais e de energia; as diferentes emissões para o ar, água e terra, considerando as diferentes categorias de impacto; bem como as fronteiras definidas, com os resultados ponderados pela unidade funcional.

De acordo com a Norma ABNT NBR ISO 14041:2004 ${ }^{22}$ é recomendável que sejam realizadas todas as etapas operacionais delineadas na Figura 4, para 0 sucesso de um ICV. 


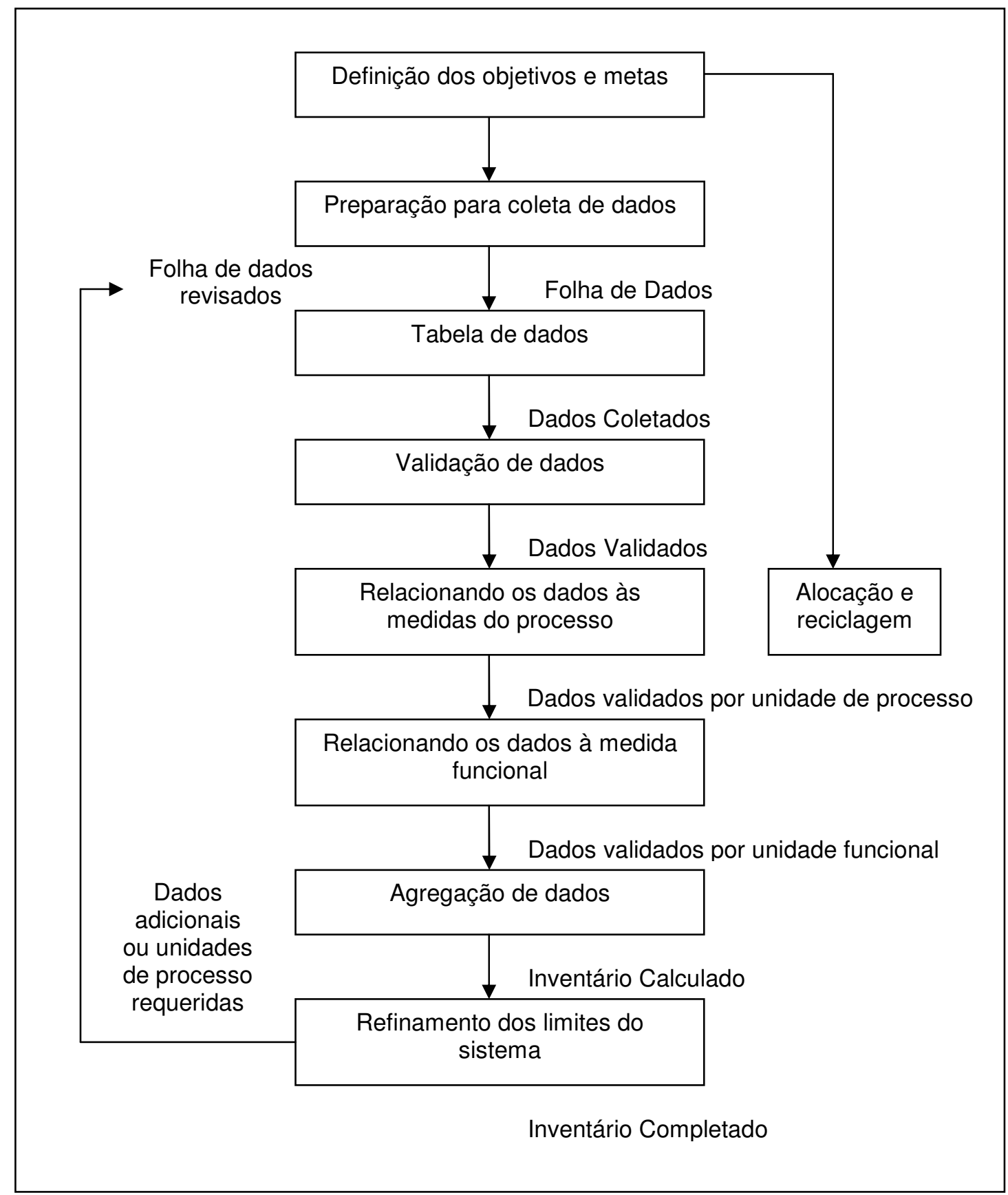

Figura 4 - Etapas operacionais de um ICV

Fonte: Norma ABNT NBR ISO 14041: $2004^{22}$

\subsubsection{Preparação para a coleta de dados}

Como foi citado em 2.3.1.1.2, página 41, o escopo do estudo estabelece os subsistemas que deverão constituir o sistema de produto em estudo, entre outros parâmetros. Como na etapa de coleta de dados serão levantadas muitas 
informações provenientes de diferentes fontes, épocas e consistência, é recomendável o estabelecimento prévio de etapas visando assegurar a compreensão uniforme e consistente dos sistemas de produto a serem estudados, bem como a objetividade do estudo e a adequação do tempo gasto no mesmo. Estas etapas devem incluir:

- A elaboração de fluxogramas de processo que representem os subsistemas, as unidades e as inter-relações que os caracterizam, tanto com o meio ambiente, quanto com os outros subsistemas e sistemas ligados a ele;

- A preparação de formulários para a coleta de dados, com especificação das unidades de medida;

- Definição de critérios de exclusão de aspectos ambientais, visando o refinamento do ICV.

Ao se realizar um ICV são levantados muitos dados de pouquíssima relevância ambiental. Assim sendo, é necessário estabelecer critérios de exclusão de aspectos ambientais. Estes critérios são em geral de duas naturezas, a saber:

- Relevância ambiental - este critério permite decidir sobre os efeitos provocados, por exemplo, pela disposição de rejeitos de um sistema de produto nas suas vizinhanças. Ele se baseia em uma análise de sensibilidade, o que garante maior confiabilidade para o ICV;

- Quantitativo - com base neste critério deve ser excluído do estudo corrente de matéria ou energia cuja contribuição para a massa ou energia total que entra ou sai do sistema seja inferior a uma determinada porcentagem, estabelecida no escopo da ACV. Os valores mais frequentemente utilizados são 1,0\%, 2,5\% e $5,0 \%{ }^{32}$.

O critério quantitativo é o mais usado, principalmente devido a economia de tempo e de investimento. A sua aplicação generalizada pode, contudo, resultar na desconsideração de aspectos ambientais que podem se reverter em impactos ambientais significativos. Devido a isso, a Norma ABNT NBR ISO 14041:2004 ${ }^{22}$ estabelece que quando se pretende que o estudo apóie uma afirmação comparativa para divulgação pública, seja realizada análise de sensibilidade de todos os aspectos ambientais relacionados ao sistema de produto em estudo. 
- A descrição das técnicas de coleta de dados, bem como o estabelecimento de parâmetros para julgar a ocorrência de casos especiais, fortuitos, irregularidades ou outros itens associados com o levantamento dos dados.

A Tabela 1 apresenta um modelo típico de questionário para a coleta de dados de um ICV, segundo CHEHEBE².

Tabela 1 - Folha de coleta de dados

\begin{tabular}{|c|c|c|c|c|}
\hline \multicolumn{2}{|l|}{ PROCESSO: } & \multicolumn{3}{|l|}{ DATA: } \\
\hline \multicolumn{5}{|c|}{ BALANÇO DE MASSA } \\
\hline \multicolumn{3}{|c|}{ ENTRADA DE MATÉRIAS PRIMAS } & \multicolumn{2}{|c|}{ SAÍDAS } \\
\hline \multicolumn{2}{|c|}{ OUTRAS ENTRADAS } & \multicolumn{3}{|c|}{ Comentários: } \\
\hline \multicolumn{5}{|c|}{$\begin{array}{l}\text { ENTRADA DE ENERGIA } \\
\text { FONTES ENERGÉTICAS }\end{array}$} \\
\hline \\
\hline & & & & \\
\hline \multicolumn{5}{|c|}{ TRANSPORTE } \\
\hline $\begin{array}{l}\text { ATIVIDADES DE } \\
\text { TRANSPORTE }\end{array}$ & MEIO DE TRANSPORTE & \multicolumn{2}{|l|}{ DISTÂNCIA } & CARGA \\
\hline & & & & \\
\hline \multicolumn{5}{|c|}{ DADOS AMBIENTAIS } \\
\hline \multicolumn{5}{|c|}{ EMISSÕES ATMOSFÉRICAS } \\
\hline \multicolumn{5}{|c|}{ EFLUENTES LÍQUIDOS } \\
\hline \multicolumn{2}{|c|}{ RESÍDUOS SÓLIDOS } & & & \\
\hline
\end{tabular}

Fonte: Chehebe ${ }^{2}$

\subsubsection{Coleta de dados}

A coleta de dados é, segundo vários autores, a etapa de um ICV que mais consome tempo e recursos. ${ }^{2,27,28}$

Segundo Wenzel et al $(1997)^{29}$, os dados de um ICV deveriam ser, basicamente, dados primários, ou seja, aqueles obtidos de medições diretas no 
campo. Entretanto, na grande maioria dos estudos da ACV, estes dados são complementados com os dados secundários, obtidos em geral das seguintes fontes ${ }^{2}$ :

- Normas Técnicas da: ABNT, ISO, Deutsches Institut für Normung (DIN), etc;

- Estatísticas ambientais;

- Literatura técnico-científica especializada;

- Licenças ambientais;

- Informação interna de empresas;

- Associações de Classe: Nickel Institut (NI), International Chromium Development Association (ICDA), International Molybdenum Association (IMOA), International Iron Steel Institute (IISI), etc;

- Fornecedores;

- Bancos de dados de ACV: Swiss Agency for Environment, Florest and Landscape (Buwal), Swiss Federal Institute of Technology (ETH), etc.

O uso de dados secundários precisa ser feito com grande atenção, pois eles podem estar desatualizados, serem imprecisos, terem sido gerados tomando como base objetivos e escopos diferentes, entre outros fatores impeditivos ${ }^{32}$. Mesmo o uso de dados provenientes de banco de dados de ACV internacionais merece atenção, pois podem estar baseados em matrizes energéticas diferentes, sistemas de transporte idem, etc. Estas dificuldades foram muito bem consideradas por Kulay ${ }^{30}$, que reafirma a importância da construção de um banco de dados brasileiro, no sentido de tornar esta importante ferramenta de gestão ambiental cada dia mais presente no processo gerencial de tomada de decisão da indústria e do setor de serviços nacional.

Quando são utilizados dados secundários, a fonte deve ser referenciada.

A Tabela 2 apresenta o ICV de um produto genérico, segundo Mourad ${ }^{6}$. 
Tabela 2 - Exemplo de um ICV de um produto genérico

\begin{tabular}{|c|c|c|}
\hline Parâmetro & Unidade & Quantidade $/ 1000 \mathrm{Kg}$ produto \\
\hline \multicolumn{3}{|l|}{ ENERGIA (entrada) } \\
\hline Total & MJ & 6000 \\
\hline Hidrelétrica & MJ & 4800 \\
\hline Queima de combustíveis & MJ & 1200 \\
\hline \multicolumn{3}{|l|}{ RECURSOS NATURAIS (entrada) } \\
\hline Água & $\mathrm{kg}$ & 3000 \\
\hline Carvão & $\mathrm{kg}$ & 1270 \\
\hline Madeira - reflorestamento & $\mathrm{kg}$ & 300 \\
\hline Madeira - virgem & $\mathrm{kg}$ & 80 \\
\hline Gás natural & $\mathrm{kg}$ & 140 \\
\hline Petróleo & $\mathrm{kg}$ & 2500 \\
\hline Constituintes minoritários & $\mathrm{kg}$ & 13 \\
\hline \multicolumn{3}{|l|}{ USO DE TERRA (entrada) } \\
\hline Uso contínuo & $\mathrm{m}^{2} /$ ano & 6,4 \\
\hline Uso único & $\mathrm{m}^{2}$ & 8,3 \\
\hline \multicolumn{3}{|l|}{ RESÍDUO SÓLIDO (saída) } \\
\hline Reciclagem externa ao sistema & $\mathrm{kg}$ & 3,8 \\
\hline Resíduo tóxico & $\mathrm{kg}$ & 0,07 \\
\hline Resíduo de processo industrial & $\mathrm{kg}$ & 70 \\
\hline Volume usado para disposição final & $\mathrm{dm}^{3}$ & 88 \\
\hline \multicolumn{3}{|l|}{ EMISSÕES PARA O AR (saída) } \\
\hline Particulados & $\mathrm{kg}$ & 2,7 \\
\hline Gás carbônico $\left(\mathrm{CO}_{2}\right)$ (renovável) & $\mathrm{kg}$ & 278 \\
\hline Gás carbônico $\left(\mathrm{CO}_{2}\right)$ (não-renovável) & $\mathrm{kg}$ & 3300 \\
\hline Monóxido de carbono (CO) & $\mathrm{kg}$ & 67 \\
\hline Metano $\left(\mathrm{CH}_{4}\right)$ & $\mathrm{kg}$ & 2,0 \\
\hline Óxidos do enxofre $\left(\mathrm{SO}_{\mathrm{x}}\right)$ como $\mathrm{SO}_{2}$ & $\mathrm{~kg}$ & 1,4 \\
\hline Compostos orgânicos voláteis (COVs) & $\mathrm{kg}$ & 0,5 \\
\hline \multicolumn{3}{|l|}{ EMISSÕES PARA A ÁGUA (saída) } \\
\hline DBO & g & 150 \\
\hline DQO & g & 1100 \\
\hline Sólidos suspensos & g & 250 \\
\hline Sólidos solúveis & g & 0,54 \\
\hline Metais pesados & g & 300 \\
\hline Óleos e gorduras & $\mathrm{g}$ & 0,04 \\
\hline
\end{tabular}

$\left({ }^{*}\right)$ Valores hipotéticos

Fonte: Adaptado de MOURAD, A. L. et al ${ }^{6}$ 
2.3.2.2.1 Substituição de dados primários e validação dos dados

Como um estudo de ICV envolve uma coleta complexa de dados, estes precisam ser validados através de balanços de massa, de balanços de energia de análises comparativas de fatores de emissão, etc. Estes procedimentos de validação podem indicar a necessidade de substituição de alguns dados, bem como com certa freqüência alguns dados primários não podem ser obtidos ou conseguí-los tornaria muito difícil o andamento do ICV, torna-se necessário a inclusão de dados secundários. A Norma NBR ISO $14041^{22}$ indica os procedimentos a serem adotados: - Utilizar um valor de dado "diferente de zero" extraído da literatura, ou estimar um valor através de balanços de massa e energia dentro da unidade de processo. Nesses casos, as considerações que orientam esses procedimentos precisam ser documentadas baseadas em conhecimentos técnico-científicos relevantes;

- Atribuir um valor de dado "zero", que seja justificado tecnicamente;

- Utilizar um valor calculado com base nos valores característicos de processos elementares que empreguem tecnologias semelhantes às empregadas no sistema em estudo.

Os dados faltantes que foram complementados precisam atender aos requisitos de qualidade de dados estabelecidos pelas Normas ABNT NBR ISO 14040:2001 ${ }^{21}$ e ABNT NBR ISO 14041:2004 ${ }^{22}$.

Conforme citado anteriormente, um estudo de ACV é um processo iterativo, englobando as diferentes etapas que a compõe. Desta forma, após a coleta de dados e, principalmente, após a sua validação, torna-se necessário retornar às definições do objetivo e do escopo de forma a avaliar, criticamente, o pleno atendimento de ambos ou fazer as revisões necessárias.

2.3.2.2.2 Relacionando dados ao processo elementar, à unidade funcional e à agregação de dados.

Após a coleta e validação dos dados são geradas inúmeras planilhas de aspectos ambientais, individualizados para cada unidade de processo. Esses dados 
precisam ser normalizados, a fim de serem colocados em uma mesma base. Para isso, a Norma ABNT NBR ISO 14041:2004 ${ }^{22}$ dispõe que todos os fluxos de uma unidade de processo estejam na mesma unidade de medida, que pode ser $1 \mathrm{~kg}$ de material ou 1 MJ de energia, por exemplo. Os dados de entrada e de saída de cada unidade de processo devem ser, então, referenciados a unidade funcional e as unidades devem ser interconectadas umas às outras, resultando em dados finais normalizados.

\subsection{Refinamento das fronteiras do sistema}

As definições do objetivo e do escopo servem como base para a delimitação das dimensões da ACV e das fronteiras do sistema em estudo.

Com o avanço do trabalho de ICV, tem-se maior conhecimento a respeito do atendimento ao objetivo do estudo. Tendo em vista a natureza iterativa da ACV, a Norma ABNT NBR ISO 14041:2004 22 recomenda a revisão periódica do sistema de produto em estudo e, especialmente, as suas fronteiras, de forma a garantir o atendimento ao objetivo do estudo ou poder reformulá-lo. Esse aperfeiçoamento deve ser realizado por meio de análises de sensibilidades, que objetivam avaliar a necessidade de:

- Exclusão de estágios do ciclo de vida ou de processos elementares que não sejam significantes;

- Exclusão de fluxos de materiais ou energia pouco relevantes aos resultados do estudo e,

- Inclusão de novos processos elementares ou de aspectos ambientais que se mostrem significativos na análise de sensibilidade.

Os resultados deste processo devem ser documentados.

A avaliação dos riscos à saúde ou relativas a qualquer tipo de impacto ambiental; bem como conclusões e propostas de melhoria do sistema em estudo serão analisadas na próxima fase do estudo de $A C V$, a avaliação do impacto do ciclo de vida. 


\subsubsection{Avaliação do Impacto do Ciclo de Vida (AICV)}

A fase de AICV é dirigida à avaliação da significância de impactos ambientais potenciais, usando os resultados da análise de inventário do ciclo de vida. Em geral, este processo envolve a associação de dados de inventário com impactos ambientais específicos e a tentativa de compreender estes impactos. O nível de detalhe, a escolha dos impactos avaliados e as metodologias usadas dependem do objetivo e do escopo do estudo, segundo a NBR ISO 14040:2001 ${ }^{21}$. Esta avaliação pode incluir o processo iterativo de análise crítica do objetivo e do escopo do estudo da ACV, para determinar quando os objetivos do estudo foram alcançados ou modificá-los, se a avaliação indicar que eles não poderão ser atingidos.

\subsubsection{Características-chave da AICV}

Segundo a ABNT NBR ISO 14042:2004 ${ }^{23}$, as principais característicaschaves de uma AICV são:

- A AICV apresenta um panorama abrangente dos aspectos ambientais e de recursos associados ao sistema de produto em estudo;

- A AICV estabelece uma relação mútua entre resultados do ICV às categorias de impacto. Para cada categoria de impacto é selecionado um indicador de categoria e o resultado desse indicador é então calculado. $O$ conjunto destes indicadores passa a ser o perfil da AICV e fornecerá dados a respeito das questões ambientais associadas ao sistema de produto em estudo;

- A AICV é uma abordagem relativa baseada em uma unidade funcional. A AICV pode fazer uso de outras técnicas de avaliação, tais como a avaliação de desempenho ambiental, a avaliação do impacto ambiental, a avaliação de riscos, entre outras. 


\subsubsection{Elementos da AICV}

A AICV é composta de elementos obrigatórios que convertem os resultados do ICV em resultados dos indicadores de categoria de impacto ambiental (perfil da AICV) e os elementos opcionais, que tratam da normalização, do agrupamento e da valoração desses indicadores. Os elementos da AICV são apresentados na Figura 5, na qual ficam evidenciadas as relações mútuas entre os elementos obrigatórios e os opcionais.

\section{Avaliação do impacto do ciclo de vida}

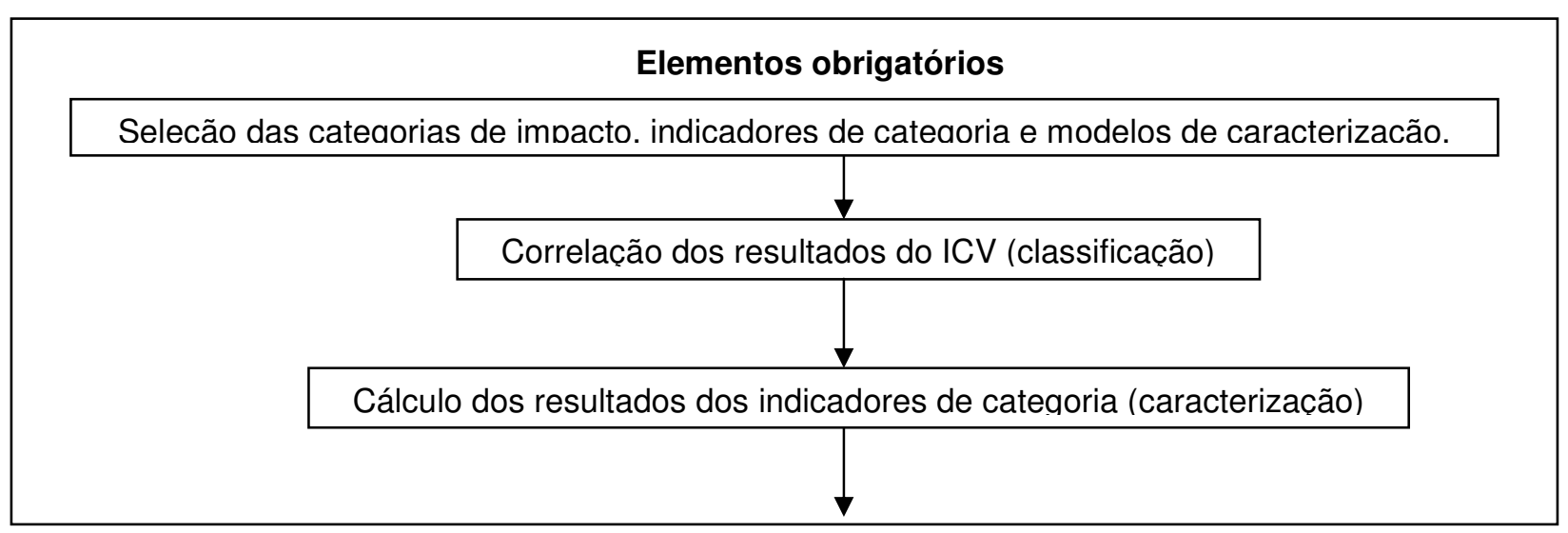

Resultados dos Indicadores de categoria (perfil da AICV)

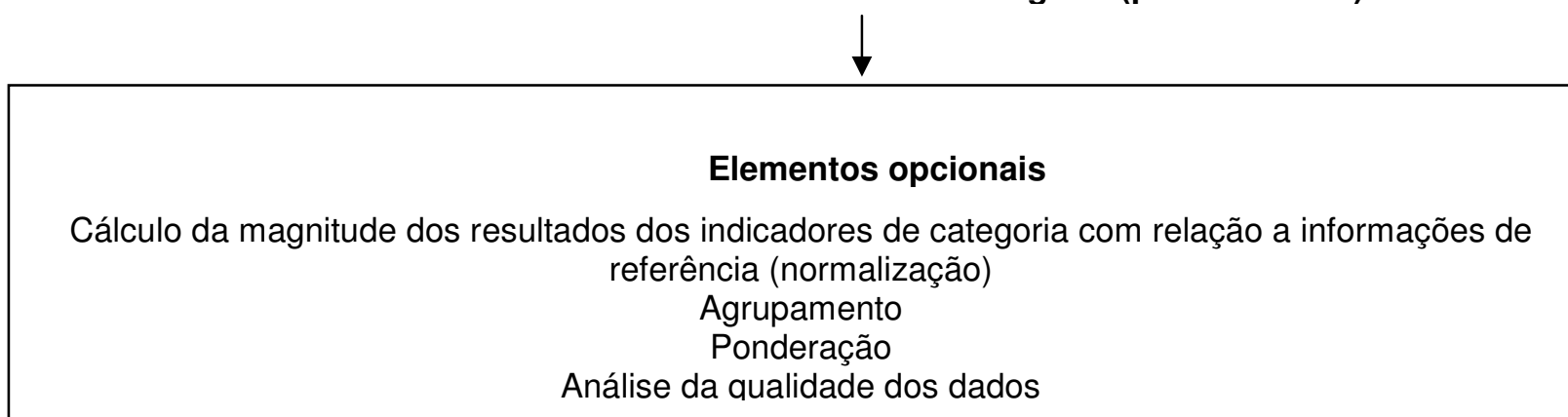

Figura 5 - Elementos da etapa de AICV

Fonte: ABNT NBR ISO $14042 .^{23}$ 


\subsection{Elementos obrigatórios}

a) Seleção de categorias de impacto, indicadores de categoria e modelos de caracterização.

Segundo $\mathrm{CHEHEBE}^{2}$, os principais critérios para seleção de categorias de impacto são:

- As categorias devem ser definidas com base no conhecimento científico;

- Todas as categorias devem ser definidas de forma clara e transparente;

- As categorias devem explicitar o(s) foco(s) do(s) problema(s) ambiental(is) em estudo e devem representar tanto as preocupações do estudo quanto efeitos cientificamente observáveis sobre os recursos naturais, meio ambiente ou saúde humana;

- Os resultados do ICV para uma determinada categoria devem estar relacionados por um mecanismo comum e homogêneo ao foco da preocupação ambiental;

- As categorias devem permitir a clara identificação dos dados apropriados do ICV e que levam em consideração o foco de preocupação ambiental.

A partir destes critérios, as categorias de problemas ambientais mais usadas são: $:^{2,6}$

- Consumo de recursos naturais - esta categoria enfoca a extração de combustíveis fósseis ou minerais, minérios, etc., para uso como fonte energética e como matéria prima de processos industriais e o uso da água. A água utilizada precisa ser avaliada quanto ao volume requerido e pela alteração da pureza, temperatura e qualidade. Madeira, cana de açúcar e outras fontes energéticas renováveis também precisam ser consideradas, tendo em vista a necessidade da sua utilização de modo sustentável.

- Aquecimento global - a emissão de quantidades crescentes de $\mathrm{CO}_{2}$, metano $\left(\mathrm{CH}_{4}\right)$, monóxido de dinitrogênio $\left(\mathrm{N}_{2} \mathrm{O}\right)$, vapor d'água, aerossóis e outros gases na atmosfera terrestre estão conduzindo a uma absorção cada vez maior das radiações refletidas pela terra e, consequentemente, ao aquecimento global, também conhecido como efeito estufa; 
- Redução da camada de ozônio - a diminuição desta camada na estratosfera permite que a radiação ultravioleta emitida pelo sol chegue à Terra com maior intensidade, o que pode aumentar a ocorrência de câncer de pele, doenças oculares e interferências no ecossistema;

- Toxicidade humana - a exposição a substâncias tóxicas como compostos aromáticos, hidrocarbonetos halogenados, metais pesados, etc, através do ar, água ou solo e, especialmente, através da cadeia alimentar, pode causar problemas à saúde humana. O "Mal de Minamata", por exemplo, foi uma doença causada pelo consumo de peixes e frutos do mar contaminados por mercúrio;

- Ecotoxicidade - a exposição a substâncias tóxicas também pode causar danos à flora e a fauna, algumas vezes irreversíveis;

- Acidificação - ocorre quando gases como $\mathrm{SO}_{2}$ e $\mathrm{NO}_{x}$ são dissolvidos na água da chuva e, ao atingirem a superfície terrestre, acidificam o solo e as águas, prejudicando as lavouras, florestas, meios aquáticos, além de causarem danos às estruturas metálicas e edificações;

- Fumaça fotoquímica oxidante - sob a ação dos raios ultravioleta, os óxidos de nitrogênio reagem com compostos orgânicos voláteis (COV) presentes no ar, produzindo compostos oxidantes fotoquímicos que retornam à superfície terrestre na forma de nevoeiro. Estas substâncias causam doenças respiratórias e a sua ação tem sido observada nos grandes centros urbanos, onde é mais difícil dissipar a nuvem de poluentes;

- Nutrificação e eutrofização - é a adição de nutrientes ao solo ou à água, respectivamente, levando a produção de biomassa. $\mathrm{Na}$ água, isso conduz a uma redução do oxigênio $\left(\mathrm{O}_{2}\right)$ disponível, afetando a flora e a fauna aquática. Tanto na água quanto no solo este efeito pode levar à redução do número de espécies do ecossistema e, portanto, alterar a biodiversidade. Vários elementos apresentam efeito nutritivo. Nitrogênio e fósforo são os mais importantes.

Existem ainda várias outras categorias de impacto que poderão ser incluídas em um estudo, no entanto, sem ainda uma ampla concordância científica internacional. Exemplos dessas categorias são²:

- Exigências especiais (para aterro, por exemplo);

- Poluição sonora; 
- Odor;

- Segurança ocupacional.

b) Correlação dos resultados do ICV (classificação)

Esta etapa estabelece parâmetros para o relacionamento qualitativo dos aspectos ambientais quantificados no ICV, com as categorias de impacto às quais eles contribuem. Cabe destacar que alguns aspectos ambientais podem contribuir para mais de uma categoria, simultaneamente. Exemplos típicos são o $\mathrm{SO}_{2}$, que é alocado entre as categorias de impacto, toxidade humana e acidificação e o $\mathrm{NO}_{x}$, que pode ser correlacionado tanto à formação de ozônio ao nível do solo, oxidante fotoquímico, como à acidificação.

c) Cálculo dos resultados dos indicadores de categoria (caracterização)

A caracterização é um passo quantitativo baseado na análise científica dos aspectos ambientais considerados relevantes no objetivo e escopo do sistema de produto em estudo. A caracterização coloca em uma mesma base diferentes parâmetros (aspectos ambientais) que contribuem para uma mesma categoria de impacto.

Muita pesquisa de alto nível tem sido realizada em todo o mundo em busca de consenso internacional no estabelecimento dos fatores de equivalência para as diferentes substâncias, em relação às diferentes categorias de impacto. Apresenta-se, a seguir, uma descrição sumarizada das categorias de impacto selecionadas para os estudos de AICV, segundo vários autores: ${ }^{2,18,19,29}$

- Exaustão de recursos não renováveis

Esta categoria enfoca a extração de combustíveis fósseis ou minerais, minérios, etc. O Potencial de Exaustão de Recursos não Renováveis converte os dados de ICV numa relação das quantidades do recurso utilizado versus a quantidade de recurso conhecida deste material. $\mathrm{O}$ escopo desta categoria pode ser local, regional ou global.

- Aquecimento global

Esta categoria está relacionada à emissão de gases de efeito estufa para a atmosfera $\left(\mathrm{CO}_{2}, \mathrm{CH}_{4}, \mathrm{NO}_{x}, \mathrm{~N}_{2} \mathrm{O}\right.$, etc.) que está conduzindo a uma absorção cada vez maior das radiações refletidas pela terra $e$, conseqüentemente, ao aquecimento global. Para esta categoria é utilizado o 
modelo de caracterização proposto pelo International Panel for Climate Change (IPCC). O escopo geográfico deste indicador é mundial e o seu horizonte temporal é de 100 anos. Este indicador é expresso como Potencial de Aquecimento Global (PAG 100), na forma de $\mathrm{kg} \mathrm{CO}_{2} / \mathrm{kg}$ gás emitido. A Tabela 3 mostra esta relação para alguns gases, como exemplo:

\section{Tabela 3 - Potencial de aquecimento global para alguns gases}

\begin{tabular}{|c|c|}
\hline Gás & Potencial de aquecimento global (PAG 100) \\
\hline $\mathrm{CO}_{2}$ & 1 \\
\hline $\mathrm{CH}_{4}$ & 21 \\
\hline $\mathrm{NO}_{\mathrm{x}}$ & 254 \\
\hline $\mathrm{N}_{2} \mathrm{O}$ & 310 \\
\hline $\mathrm{HCFC}$ & 1600 \\
\hline $\mathrm{CFC}-11$ & 3400 \\
\hline CFC -12 & 7100 \\
\hline
\end{tabular}

Fonte: Adaptado de Paola, J. C. C. ${ }^{27}$

Desta Tabela conclui-se que $1 \mathrm{~kg}$ de $\mathrm{CH}_{4}$ apresenta o mesmo efeito estufa que $21 \mathrm{~kg}$ de $\mathrm{CO}_{2}$.

- Redução da Camada de Ozônio

A diminuição desta camada na estratosfera permite que a radiação ultra violeta emitida pelo sol chegue à terra com maior intensidade, o que pode aumentar a ocorrência de câncer de pele, doenças oculares e interferência nos ecossistemas terrestres e aquáticos.

O indicador para esta categoria é o Potencial de Depleção da Camada de Ozônio (PDCO), desenvolvido pela World Meterological Organization (WMO). Este indicador relaciona para diferentes gases a sua equivalência em termos de $\mathrm{kg}$ de CFC-11/Kg emissão. O seu horizonte temporal é infinito e o seu alcance geográfico é mundial.

- Toxicidade humana

Esta categoria está relacionada aos efeitos adversos à saúde humana ocasionados por substâncias tóxicas. Os fatores que caracterizam esta categoria são medidos como Potencial de Toxicidade Humana (PTH) e expressos em relação a massa em $\mathrm{kg}$ de 1,4-diclorobenzeno equivalente $/ \mathrm{kg}$ emissão. Os valores de PTH são calculados por meio de testes do tipo dose- 
resposta, cujos horizontes temporais são geralmente infinitos. Tendo em vista as diferentes características das substâncias, a extensão geográfica pode ser local, regional, continental e, até mesmo, mundial.

- Ecotoxicidade Aquática

Esta categoria é analisada de forma semelhante à toxicidade humana. O Potencial de Ecotoxicidade Aquática ( $P E a$ ) também é calculado em termos de $\mathrm{kg}$ de 1,4-diclorobenzeno equivalente $/ \mathrm{kg}$ emissão e trata de impactos causados sobre ecossistemas de águas doces por substâncias tóxicas presentes em emissões aéreas ou aquosas.

- Ecotoxicidade Terrestre

Esta categoria é analisada de forma semelhante à ecotoxicidade aquática. O Potencial de Ecotoxicidade Terrestre (PEt) também é calculado em termos de $\mathrm{kg}$ de 1,4-diclorobenzeno equivalente $/ \mathrm{kg}$ emissão e trata de impactos causados sobre ecossistemas terrestres por substâncias tóxicas presentes em emissões aéreas ou aquosas.

- Acidificação

Gases acidificantes como $\mathrm{SO}_{2}$ e $\mathrm{NO}_{x}$ quando dissolvidos na água da chuva, ao atingirem a superfície terrestre podem ocasionar sérios impactos ao solo, meios aquáticos, à flora e à fauna, além de causarem danos às estruturas metálicas e edificações.

Os impactos ambientais dessa natureza ocasionados por emissões atmosféricas são descritos como Potenciais de Acidificação (PAC) e são expressos em $\mathrm{kg}$ de $\mathrm{SO}_{2}$ equivalente $/ \mathrm{kg}$ emissão. O seu alcance temporal é infinito e a sua extensão geográfica varia de local à continental.

- Formação de Oxidantes Fotoquímicos

Esta categoria refere-se aos efeitos tóxicos causados pelos compostos oxidantes fotoquímicos, formados pela reação de Compostos Orgânicos Voláteis e óxidos de nitrogênio, sob a ação dos raios ultra-violeta. Os fatores que caracterizam esta categoria são calculados em termos de $\mathrm{kg}$ de etileno equivalente $/ \mathrm{kg}$ emissão, possuem alcance temporal infinito e a extensão geográfica varia entre local à continental. 
- Nutrificação ou Eutrofização

Compreende os impactos causados em decorrência do nível excessivo de nutrientes presentes no meio ambiente em virtude da disposição de rejeitos no ar, na água e no solo.

O estabelecimento do chamado Potencial de Eutrofização (PEu) baseia-se em um procedimento estequiométrico proposto por HEIJUNGS (1992), citado por CARVALHO, C. E. ${ }^{31}$, cujos resultados são expressos em kg de $\mathrm{PO}_{4}$ equivalente / $\mathrm{kg}$ emissão. Este modelo apresenta limite temporal infinito e uma escala geográfica variável entre local e continental.

Ao final da caracterização obtém-se um valor total da contribuição do ciclo de vida do sistema de produto em estudo, para cada categoria de impacto. O conjunto de valores obtidos para as várias categorias de impacto constitui o perfil ambiental do sistema de produto em estudo ${ }^{32}$.

Tendo em vista ao estabelecido no objetivo e no escopo da ACV, esse resultado pode ser suficiente para a avaliação, já que apresenta e quantifica as contribuições do ciclo de vida do produto às categorias de impacto.

O Anexo A, adaptado de CARVALHO, C. E. ${ }^{31}$, apresenta os potenciais de alguns gases para determinadas categorias de impacto.

\subsection{Elementos opcionais}

Os elementos opcionais da ACV são três: normalização, agrupamento e ponderação. A normalização relaciona os resultados da etapa de caracterização com uma referência escolhida. $O$ agrupamento e a ponderação complementam a etapa de AICV e empregam escolha de valores, baseados em questões regionais, temporais e até mesmo políticas. São seções menos científicas de uma AICV.

a) Normalização

A seção de caracterização fornece o perfil ambiental do sistema de produto em estudo que, dependendo dos valores envolvidos, pode ser de difícil comparação e interpretação, visto que os impactos ambientais que o constituem estão 
calculados em unidades diferentes. Esta dificuldade pode ser superada fazendose a conversão de todos os indicadores de categoria a uma única base de referência que pode $\operatorname{ser}^{14}$ :

- Um determinado produto ou sistema;

- Uma determinada condição de referência (área de trabalho, tempo, média de um setor industrial, etc.);

- Um determinado valor crítico (limite legal, valor acertado internacionalmente, etc.);

- Um valor econômico do custo do impacto ambiental (exemplo, custo de prevenção).

A normalização é feita dividindo-se os valores dos parâmetros pela referência escolhida. Os resultados desta operação constituirão o perfil normalizado de valores. Este perfil auxilia na hierarquização da melhoria de desempenho ambiental do sistema de produto em estudo, etapa de fundamental importância no processo gerencial de tomada de decisão.

Após esta etapa, como os indicadores ambientais normalizados possuem a mesma unidade, eles poderão ser somados para dar origem ao indicador único de impacto ambiental do sistema de produto em estudo.

b) Agrupamento

Segundo a Norma ABNT NBR ISO 14042:2004 ${ }^{23}$, esta etapa objetiva estabelecer uma relação entre as categorias de impacto, em um ou mais conjuntos, conforme estabelecido na definição de objetivo e escopo. Ela é opcional. Quando utilizada, os seus objetivos são:

- Ordenar as categorias de impacto de acordo com o seu tipo, por exemplo:

- efeitos sobre o meio físico;

- efeitos sobre o meio biótico;

- consumo de recursos naturais;

- efeitos globais, regionais ou locais, entre outros.

- Classificar as categorias de impacto segundo uma ordem de importância ou prioridade, por exemplo, como alta, média ou pequena.

É importante salientar que a classificação é baseada até certo ponto em juízo de valores. Desta forma, diferentes indivíduos, organizações e sociedades 
podem ter preferências diferenciadas, o que pode ocasionar resultados de classificação também diferentes, ainda que com base nos mesmos indicadores normalizados.

c) Ponderação

Na ponderação ou valoração as categorias de impacto são somadas entre si, de acordo com uma escala de importância para o meio ambiente, conforme préacertado na definição de objetivo e escopo, buscando-se um indicador único de desempenho ambiental para o sistema de produto em estudo ${ }^{2}$.

É importante salientar que embora até o momento grandes esforços tenham sido realizados pelos meios científicos internacionais na busca de metodologias para a ponderação, nenhum acordo geral foi alcançado com esta finalidade.

Independente da subjetividade que permeia os elementos opcionais de uma AICV fica claro a importância dos mesmos em qualquer processo gerencial de tomada de decisão envolvendo questões ambientais.

\subsubsection{Interpretação}

Os principais objetivos desta etapa são combinar, resumir e discutir as constatações da análise de inventário e da avaliação de impacto, de forma iterativa aos objetivos e escopo do estudo, previamente definidos, de forma a gerar as conclusões e recomendações ao estudo de ACV.

A fase de interpretação de uma ACV compreende a identificação dos temas de maior relevância ambiental, a avaliação dos resultados do estudo e o estabelecimento das conclusões e recomendações. ${ }^{24}$ 


\subsubsection{Identificação de temas de relevância}

Nesta seção, são identificadas as questões ambientais relevantes para 0 estudo, tomando como base os resultados do ICV.

\subsubsection{Avaliação dos resultados}

O objetivo dessa fase é garantir a confiabilidade dos resultados obtidos, bem como a sua clareza e compreensibilidade ao serem apresentados ao público-alvo. Para tal, a Norma ABNT NBR ISO $14042^{23}$ recomenda a checagem dos seguintes elementos:

- Análise de completeza (ou integridade) - objetiva assegurar que as questões ambientais significativas, previamente identificadas nas fases de ICV e AICV, estão disponíveis e completas. O resultado dessa análise pode levar à adição de informações extras ao estudo ou mesmo a uma revisão completa na análise do inventário e na avaliação de impacto, respectivamente ou, se necessário, a um ajuste nos objetivos e no escopo da ACV;

- Análise de sensibilidade - ao longo de um estudo de ACV as fronteiras escolhidas para o sistema, as estimativas e hipóteses adotadas, a qualidade dos dados empregados, os critérios de alocação de aspectos ambientais e a avaliação de impactos ambientais realizada, entre outros, introduzem incertezas nos resultados da ACV. A análise de sensibilidade objetiva, portanto, determinar o grau de confiabilidade dos resultados das análises de sensibilidade realizadas nas diferentes etapas do estudo e avaliar se as questões ambientais relevantes estão atendendo as variações estabelecidas no objetivo e escopo da $\mathrm{ACV}^{23}$.

A análise de sensibilidade pode ser conduzida através de três maneiras, à saber :

- Mudança de parâmetros chaves da ACV, tal como a unidade funcional. Recalcula-se o ICV e compara-o com a situação em referência; 
- Variação para mais ou para menos nos valores de entrada de uma variável escolhida para análise, por exemplo, variação de + ou - 20\% nas distâncias percorridas em um estudo de coleta seletiva de lixo;

- A construção de cenários com casos melhores e piores.

A análise de sensibilidade pode também resultar na exclusão de estágio(s) do ciclo de vida, de subsistemas ou de fluxo(s) de material(is), bem como na inclusão de nova(s) unidade(s) de processo, sempre que ficar comprovado que tais ações não afetam significativamente o resultado final em relação ao objetivo e escopo definidos anteriormente.

- Análise de consistência - objetiva checar a consistência de métodos, procedimentos, hipóteses, informações e tratamento de dados usados durante o estudo, com relação ao objetivo e escopo da ACV. Nesta etapa são avaliados os seguintes itens, principalmente:

- Qualidade de dados entre as etapas da ACV;

- Diferenças regionais e, ou, temporais;

- Adequação das fronteiras do sistema;

- Procedimentos de alocação; e,

- Metodologia de avaliação de impacto ambiental.

Encerrada a etapa de avaliação da confiabilidade dos resultados, o autor da ACV está em condições de estabelecer conclusões e propor recomendações aos usuários do estudo.

\subsubsection{Conclusões e recomendações}

A última etapa da quarta fase de uma ACV segundo a NBR ISO 14040:200121 é a apresentação das conclusões e recomendações do estudo, quando couber, de forma consistente com o objetivo e o escopo definidos. 


\subsubsection{Relatório}

Segundo a NBR ISO 14040:200141, os resultados da ACV devem ser relatados ao público-alvo de forma fiel, completa e exata, na forma de um relatório. O tipo e o formato do mesmo devem ser definidos na fase de escopo do estudo.

\subsubsection{Análise Crítica}

Após a emissão do relatório, o trabalho completo da ACV deve ser analisado criticamente de forma a assegurar que:

- Os métodos usados para conduzir a ACV são científica e tecnicamente válidos, bem como consistentes com a Norma NBR ISO 14040:2001 ${ }^{21}$;

- Os dados usados e as interpretações adotadas são apropriados ao objetivo do estudo;

- O relatório do estudo é transparente e consistente.

Além dos objetivos para a realização da análise crítica ela se justifica por facilitar a compreensão do estudo como um todo e por aumentar a credibilidade de estudos de ACV, em especial quando esses estudos são usados para apoiar afirmações comparativas, uma vez que essas afirmações poderão afetar partes interessadas que são externas ao estudo da ACV.

Como todos os procedimentos adotados em um estudo de ACV, o escopo da análise crítica deve ser definido na fase de definição de objetivo e escopo.

A análise crítica deve ser realizada por um especialista, que pode ser interno ou externo, independente do estudo da ACV.

\subsubsection{Aplicações da ACV}

A ACV é uma ferramenta gerencial que trata com clareza e objetividade questões ambientais complexas, tais como: ${ }^{2,6}$ 
- Gerenciamento de recursos naturais;

- Identificação dos pontos críticos de um determinado processo ou produto;

- Otimização de sistemas de produtos;

- Desenvolvimento de novos produtos e serviços;

- Estudos comparativos entre produtos e serviços;

- Otimização de sistemas de reciclagem;

- Definição de parâmetros para atribuição de rotulagem ambiental.

- Planejamento estratégico;

- Elaboração de políticas públicas;

- Seleção de materiais;

- Ecodesign;

- Marketing.

Esta relação de aplicações, mesmo que incompleta mostra a importância da ACV para o gerenciamento ambiental sustentável.

\subsubsection{Limitações da ACV}

A avaliação do ciclo de vida é uma importante ferramenta de gestão para avaliar aspectos ambientais relacionados a produtos e serviços. Independente disso é importante conhecer até onde os resultados, conclusões e recomendações da ACV podem ser aplicados.

As principais limitações da ACV são: ${ }^{2,6}$

\subsubsection{Fronteiras do sistema}

Um estudo de ACV poderia ser inacabável pelas suas dimensões e, consequentemente, pela abrangência de informações. Assim, para um estudo de ACV prático e objetivo as suas fronteiras ou limites do sistema precisam ser estabelecidos. Estas limitações restringem as comparações entre diferentes estudos 
de ACV, entretanto, avaliações comparativas dentro de um mesmo sistema podem ser realizadas, desde que os estudos tenham as mesmas fronteiras e parâmetros a considerar.

\subsubsection{Abrangência geográfica}

Um estudo de ACV precisa ter na definição de objetivo e escopo um claro posicionamento quanto à abrangência geográfica desse estudo, que pode vir a retratar a situação média de um país ou bloco de países, uma cidade ou mesmo um determinado processo produtivo.

A abrangência geográfica pode também indicar o nível tecnológico empregado, bem como a matriz de geração de energia elétrica utilizada, um dos aspectos ambientais mais utilizados na fase de inventário do ciclo de vida.

\subsubsection{Período de tempo coberto pelo estudo}

O período de tempo em que os dados foram coletados é mais um fator a ser relacionado na definição do objetivo e escopo, pois ele reflete as condições, os recursos e o nível tecnológico característicos da abrangência geográfica do estudo.

\subsubsection{Qualidade dos dados}

A etapa de coleta de dados é, na prática, a mais difícil e trabalhosa de ser executada, por uma série de razões, que vão desde a ausência de dados conhecidos e a necessidade de estimá-los, as dificuldades impostas pelas empresas para cedê-los e a pressão do tempo para a realização do estudo, entre outras. 
É importante salientar que os resultados, conclusões e possíveis recomendações de um estudo de ACV devem sempre ser avaliados frente à qualidade dos dados utilizados.

\subsubsection{Necessidade de combinação com outros instrumentos gerenciais}

A ACV é uma poderosa ferramenta de gestão ambiental. Entretanto, sempre que possível, a ACV deve estar integrada a outros instrumentos de gestão que considerem questões de viabilidade técnica, relação custo/benefício, segurança no trabalho, atendimento às necessidades do consumidor final, biodiversidade, aspectos sociais, etc, a fim de se obter um resultado final mais completo e adequado à complexidade do projeto. ${ }^{6}$

\subsubsection{Quem Usa a ACV}

Vários países têm utilizado intensamente a metodologia da ACV para traçar suas políticas governamentais com relação ao meio ambiente. ${ }^{2,6}$ Áustria, Canadá, Finlândia, França, Alemanha, Japão, Holanda, Noruega, Suécia e Estados Unidos são alguns desses.

Dentre as instituições internacionais que fazem uso constante da ACV cabe citar:

- Conselho Nórdico de Ministros (representantes da Dinamarca, Noruega, Suécia e Finlândia);

- Environmental Protection Agency;

- Society of Environmental Toxicology Chemistry;

- United Nations Environment Program;

- Organization for Economic Cooperation and Development; 
Além dos governos e das organizações mencionadas, várias empresas usam a metodologia de ACV para avaliar e otimizar os seus processos produtivos. Destacam-se a Eastman-Kodak, Procter \& Gamble, Eletrolux, General Eletric, Dow Chemical, Hewlett Packerd, Volvo, Ford, General Motors, Chrysler-Mercedes Benz, Avesta Sheffield, Coca Cola, entre outras.

No Brasil a ACV é uma ferramenta ainda pouco utilizada fora do meio acadêmico. Estima-se, no entanto, que devido à crescente participação do Brasil no mercado global, as iniciativas nessa área se multipliquem. 


\subsection{METODOLOGIA DO CUSTEIO DO CICLO DE VIDA (CCV)}

Custeio do ciclo de vida $(\mathrm{CCV})^{3,33}$ é uma metodologia moderna para a seleção de materiais ou produtos, que contabiliza os custos totais do sistema em análise, desde a sua concepção - o berço, até o fim da sua vida útil - o túmulo, ou seja, ao longo do seu ciclo de vida. Este sistema pode ser uma planta petroquímica, uma ponte, a carroceria de um ônibus, um edifício, uma usina de açúcar ou apenas os tubos do evaporador.

O que diferencia a aplicação desta metodologia com relação a outros estudos de performance é que neste são levados em conta, além dos custos de investimentos, todos os demais custos existentes durante as diferentes fases do ciclo de vida do sistema em análise, ou seja: projeto, produção, transporte, instalação, operação, manutenções programadas ou corretivas, desativação, reposição, reuso ou reciclagem dos materiais residuais ao fim da vida útil da unidade, valores obtidos pela venda destes materiais, bem como o que se deixou de ganhar em termos financeiros ou dano ao público usuário pelas horas não trabalhadas.

O somatório de todos estes custos permitirá ao interessado selecionar a alternativa mais adequada econômica e financeiramente.

O CCV permite também avaliar a influência de dados duvidosos ou falhos sobre o custo total, através de análises de sensibilidade.

Como o ciclo de vida de um sistema pode durar décadas, todos os custos incorridos neste período precisam ser tratados dentro do conceito do custo do dinheiro no tempo.

Para que os resultados de um estudo de CCV sejam confiáveis, os responsáveis pela sua realização precisam conhecer todas as etapas envolvidas, bem como as características e propriedades dos materiais que delas participam. Estas informações podem ser fornecidas pelas empresas participantes, extraídas de bancos de dados governamentais ou de instituições técnicas, ou baseadas em sólida experiência de campo.

Para facilitar aos interessados, existem hoje no mercado diversos softwares voltados para a seleção de materiais, construção de pontes, navios, residências, etc, baseados na metodologia CCV. 


\subsubsection{A metodologia do CCV}

A realização de um CCV compreende as seguintes etapas, conforme mostrado esquematicamente na Figura 6: definição da unidade a ser estudada, estimativa do ciclo de vida, elaboração do inventário para cada um dos materiais alternativos, atualização financeira e composição dos custos totais.

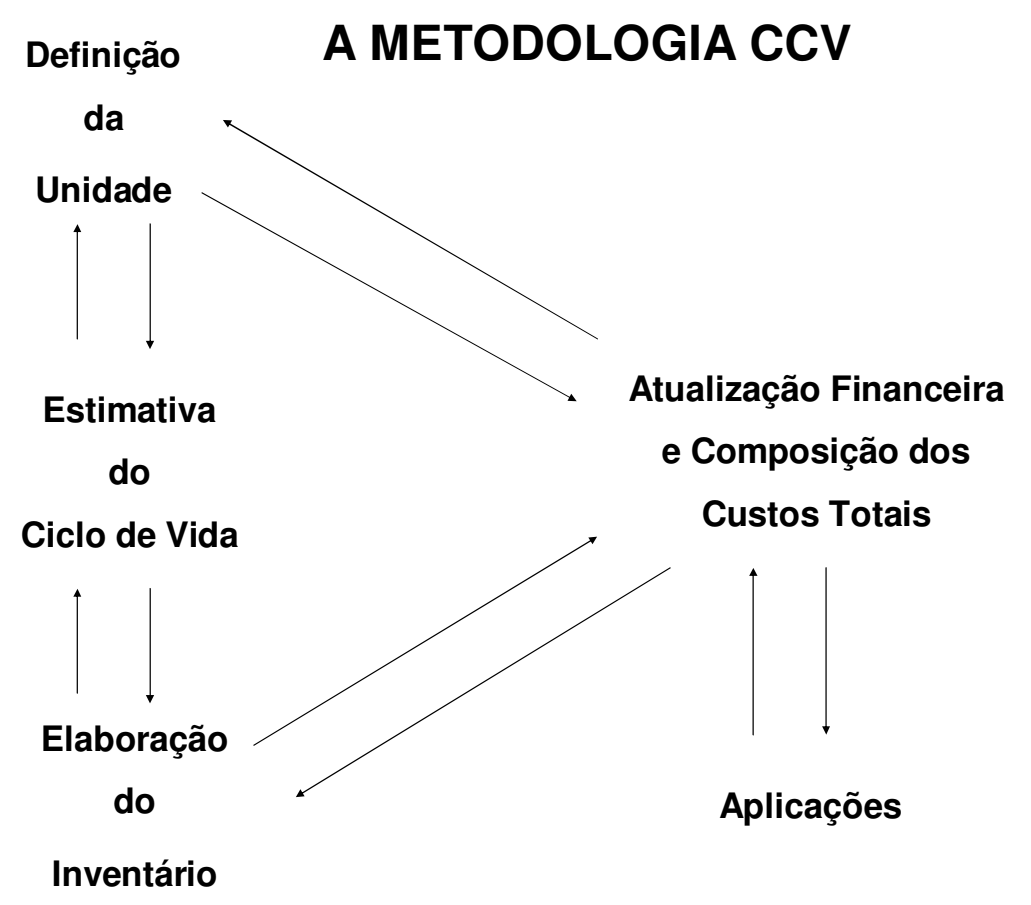

Figura 6 - Representação esquemática das etapas que compõem um CCV

\subsubsection{Definição da unidade a ser estudada}

O objetivo do CCV é possibilitar a comparação entre duas ou mais opções viáveis, permitindo à empresa que realiza o investimento selecionar a alternativa mais adequada a longo prazo. Para isto, a definição da unidade a ser estudada precisa ser clara e estabelecer os limites do sistema. Por exemplo, o estudo abrangerá uma usina de produção de açúcar, o processo de evaporação ou apenas uma bomba hidráulica para movimentação de caldo de cana. 
2.4.1.2 Estimativa do ciclo de vida

A segunda etapa consiste em estimar a vida econômica da unidade objeto do estudo e da totalidade do sistema onde ela se insere. Devem-se também definir os materiais opcionais que poderão ser utilizados. A Tabela 4 exemplifica este item:

Tabela 4 - Estimativa da vida útil do sistema e da unidade em um estudo de CCV

\begin{tabular}{|l|l|l|l|}
\hline \multicolumn{4}{|c|}{ ESTIMATIVA DO CICLO DE VIDA } \\
\hline \multicolumn{1}{|c|}{ SISTEMA } & \multicolumn{1}{|c|}{ VIDA ÚTIL } & \multicolumn{1}{c|}{ UNIDADE } & VIDA ÚTIL \\
\hline \multirow{2}{*}{ Ônibus } & 20 anos & Carroceria & 20 anos \\
\cline { 3 - 4 } & & Cano escapamento & 5 anos \\
\hline \multirow{2}{*}{ Evaporador Usina de Açúcar } & 60 anos & $\begin{array}{l}\text { Tubo aquecimento Aço } \\
\text { Inoxidável 304 }\end{array}$ & 30 anos \\
\cline { 3 - 5 } & $\begin{array}{l}\text { Tubo aquecimento Aço } \\
\text { Carbono }\end{array}$ & 6 anos \\
\hline
\end{tabular}

Os valores escolhidos devem representar uma visão realista da vida comercial da unidade e do sistema, bem como levar em consideração as características dos materiais, usos e possíveis avanços tecnológicos. Como foi apresentada, a vida útil da unidade não mantém relação com a expectativa de vida do sistema, necessariamente. Para o sistema ônibus, a vida útil da carroceria se confunde com a do sistema. O mesmo não acontece, quando se considera a unidade "cano de escapamento" que precisa ser substituído algumas vezes durante a vida útil do ônibus.

\subsubsection{Elaboração do inventário}

Esta fase de análise requer um levantamento detalhado das propriedades, especificações e custos incorridos para cada um dos materiais escolhidos durante toda a vida útil da unidade. Esta é uma fase trabalhosa, na qual a qualidade dos 
dados que constituirão os "inputs" da metodologia, é condição indispensável para a correta tomada de decisão.

\subsubsection{Atualização financeira e composição dos custos totais}

Como os custos incorridos ao longo do ciclo de vida da unidade em estudo podem estar distribuídos ao longo de décadas, é necessário levar em consideração o custo do dinheiro. Estas análises devem comparar cenários homogêneos, sendo assim, é necessário trazer todos os gastos ao Valor Presente (VP). Isto é feito utilizando-se a taxa nominal de juros, ao invés da inflação, porque neste caso, assume-se que um montante não gasto num determinado momento poderia ser aplicado no mercado financeiro. Como os resultados não variam com a moeda utilizada, os valores dos custos podem ser expressos em unidades monetárias (u.m.).

A relação entre os diferentes custos incorridos que, em conjunto, fornecem o custeio do ciclo de vida, pode ser expressa matematicamente, usando a seguinte fórmula: ${ }^{3,34,35,36}$

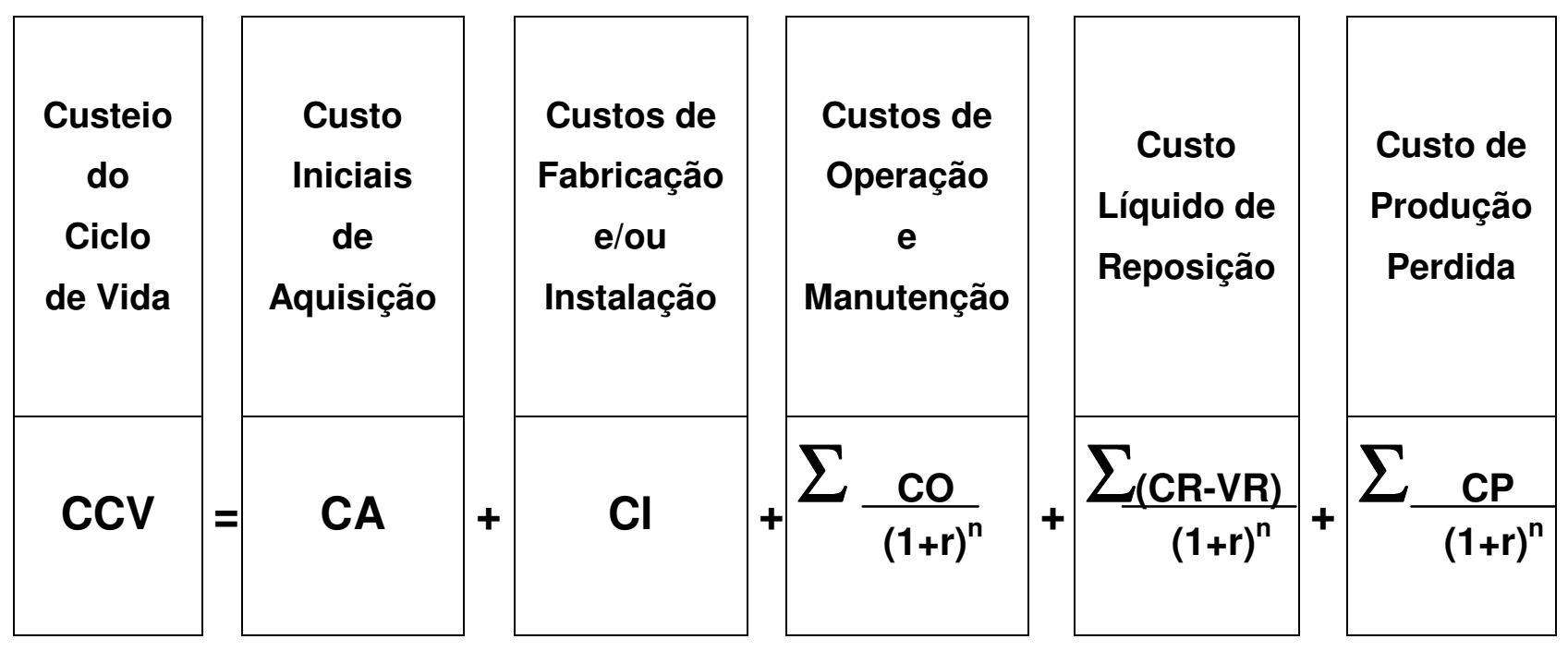

Onde:

CA = custo de aquisição para o material ou produto;

$\mathrm{Cl}=$ custo de fabricação e/ou instalação;

$\mathbf{N}=$ duração do ciclo de vida, em anos;

$\mathbf{n}=$ ano do evento;

$\mathbf{r}=$ taxa real de juros para o período de tempo considerado $(\mathbf{N})$; 
$\mathbf{C O}=$ custo operacional da unidade no ano n (somatório dos custos de operação, inspeção e manutenção);

a = número de reposições da unidade durante o ciclo de vida do sistema;

$\mathbf{C R}=$ custo de reposição número $\mathrm{n}$, da unidade;

VR = valor residual da unidade;

$\mathbf{C P}=$ custo da produção perdida, no ano $\mathrm{n}$.

Os custos de aquisição (CA) são os custos dos materiais ou produtos comprados, isto é, tubos, bombas, evaporadores, etc, colocados no local de utilização.

Os custos de fabricação ou instalação $(\mathrm{Cl})$ são os custos reais ou, na falta destes, os baseados na experiência em tarefas semelhantes. Se os materiais ou produtos em comparação admitem métodos diferentes de instalação, a custos diversos, estas características deverão ser consideradas.

Os custos de operação (CO) são a soma dos custos calculados para as inspeções, manutenções planejadas ou corretivas e outros custos variáveis devido ao material ou produto em análise, tais como mão de obra, partida(s), freqüência das manutenções e limpeza, etc.

Custos de reposição (CR) são aqueles que aparecem, quando o reparo de peças torna-se proibitivo e é necessária a substituição total. Estes custos incluem remoção, transporte e instalação dos novos materiais ou produtos. Quando o material dura todo o ciclo de vida do sistema, CR é igual a zero e permanece a receita líquida obtida pela venda do material (ou valor residual).

Valor Residual (VR) é o valor da sucata do material ou produto utilizado, após a sua vida útil.

Custo da produção perdida (CP) está relacionado ao que se deixou de ganhar devido às horas paradas para manutenção, reposição ou limpeza; bem como os possíveis danos técnicos, pessoais ou profissionais ao público usuário.

A taxa real de juros ( $r$ ) é calculada a partir do custo do capital (c) e da inflação (i) esperados para o período considerado $(\mathrm{N})$, usando a fórmula:

$$
r=c-i / 1+i
$$

Quando a inflação for muito pequena, a taxa real de juros pode ser calculada com suficiente precisão através da expressão: $\mathbf{r}=\mathbf{c}$ - $\mathbf{i}$

A duração do ciclo de vida $(\mathrm{N})$ expressa a vida econômica ativa esperada ou desejada para o sistema ou unidade em avaliação. Diferentes valores de $\mathrm{N}$ poderão influir na indicação do material ou produto mais adequado. Para sistemas com 
valores de $\mathrm{N}$ grandes, materiais com $\mathrm{CA}$ elevados e pouca freqüência de manutenção e reposição são favoráveis com relação a materiais baratos e de reposição freqüente.

O cálculo manual do valor presente pode ser facilitado utilizando-se as informações apresentadas nas Tabelas 5 e 6 . Para o mesmo cálculo também pode ser usada uma calculadora financeira, planilhas de Excell ou "softwares" específicos.

A Tabela 5 deve ser usada no cálculo do valor presente de um dado material ou produto, após n anos e a uma dada taxa real de juros ( $r$ ).

Tabela 5 - Fatores de atualização para cálculo do valor presente de um custo, a diferentes valores de taxas de juros, após um período de 1 a 100 anos

\begin{tabular}{|l|l|l|l|l|l|l|}
\hline \multirow{2}{*}{ Ano $(\mathbf{n})$} & \multicolumn{7}{|c|}{ Taxa Real de Juros $(\mathbf{r})$} \\
\cline { 2 - 7 } & $3 \%$ & $4 \%$ & $5 \%$ & $6 \%$ & $8 \%$ & $10 \%$ \\
\hline 1 & 0.971 & 0.961 & 0.952 & 0.943 & 0.926 & 0.909 \\
\hline 2 & 0.943 & 0.925 & 0.907 & 0.890 & 0.857 & 0.826 \\
\hline 3 & 0.915 & 0.889 & 0.864 & 0.840 & 0.794 & 0.751 \\
\hline 4 & 0.889 & 0.855 & 0.823 & 0.792 & 0.735 & 0.683 \\
\hline 5 & 0.863 & 0.822 & 0.784 & 0.747 & 0.681 & 0.621 \\
\hline 6 & 0.838 & 0.790 & 0.746 & 0.705 & 0.630 & 0.565 \\
\hline 7 & 0.813 & 0.760 & 0.711 & 0.665 & 0.584 & 0.513 \\
\hline 8 & 0.789 & 0.731 & 0.677 & 0.627 & 0.540 & 0.467 \\
\hline 9 & 0.766 & 0.703 & 0.645 & 0.592 & 0.500 & 0.424 \\
\hline 10 & 0.744 & 0.676 & 0.614 & 0.558 & 0.463 & 0.386 \\
\hline 11 & 0.722 & 0.650 & 0.585 & 0.527 & 0.429 & 0.351 \\
\hline 12 & 0.701 & 0.625 & 0.557 & 0.497 & 0.397 & 0.319 \\
\hline 13 & 0.681 & 0.601 & 0.530 & 0.469 & 0.368 & 0.290 \\
\hline 14 & 0.661 & 0.578 & 0.505 & 0.442 & 0.341 & 0.263 \\
\hline 15 & 0.642 & 0.555 & 0.481 & 0.417 & 0.315 & 0.239 \\
\hline 20 & 0.554 & 0.456 & 0.377 & 0.312 & 0.215 & 0.149 \\
\hline 30 & 0.412 & 0.308 & 0.231 & 0.174 & 0.099 & 0.057 \\
\hline 40 & 0.307 & 0.208 & 0.142 & 0.097 & 0.046 & 0.022 \\
\hline 50 & 0.228 & 0.141 & 0.087 & 0.054 & 0.021 & 0.009 \\
\hline 60 & 0.170 & 0.095 & 0.054 & 0.030 & 0.010 & 0.003 \\
\hline 70 & 0.126 & 0.064 & 0.033 & 0.017 & 0.005 & 0.001 \\
\hline 80 & 0.094 & 0.043 & 0.020 & 0.009 & 0.002 & \\
\hline 90 & 0.070 & 0.029 & 0.012 & 0.005 & & \\
\hline 100 & 0.052 & 0.020 & 0.008 & 0.003 & & \\
\hline & & & & & & \\
\hline
\end{tabular}

Fonte: Adaptado de Matern, S. ${ }^{3}$ e Gitman, L. J. ${ }^{37}$

Para o cálculo do valor de atualização foi usada a fórmula:

Fator de atualização $=(1+r)^{-n}$, onde $r$ é a taxa real de juros e $n$ o número de anos. 
A Tabela 6 apresenta fatores que, multiplicados ao valor inicial, fornecem a soma dos valores presentes após n anos, a uma taxa real de juros (r).

Tabela 6 - Fatores de atualização para cálculo do valor presente de um custo, a diferentes valores de taxas de juros, após um período de 1 a 100 anos

\begin{tabular}{|l|l|l|l|l|l|l|}
\hline \multirow{2}{*}{ Ano $(\mathbf{n})$} & \multicolumn{7}{|c|}{ Taxa Real de Juros $(\mathbf{r})$} \\
\cline { 2 - 7 } & $3 \%$ & $4 \%$ & $5 \%$ & $6 \%$ & $8 \%$ & $10 \%$ \\
\hline 1 & 0.971 & 0.962 & 0.952 & 0.943 & 0.926 & 0.909 \\
\hline 2 & 1.914 & 1.886 & 1.859 & 1.833 & 1.783 & 1.736 \\
\hline 3 & 2.829 & 2.775 & 2.723 & 2.673 & 2.577 & 2.487 \\
\hline 4 & 3.717 & 3.630 & 3.546 & 3.465 & 3.312 & 3.170 \\
\hline 5 & 4.580 & 4.452 & 4.329 & 4.212 & 3.993 & 3.791 \\
\hline 6 & 5.417 & 5.242 & 5.076 & 4.917 & 4.623 & 4.355 \\
\hline 7 & 6.230 & 6.002 & 5.786 & 5.582 & 5.206 & 4.868 \\
\hline 8 & 7.020 & 6.733 & 6.463 & 6.210 & 5.747 & 5.335 \\
\hline 9 & 7.786 & 7.435 & 7.108 & 6.802 & 6.247 & 5.759 \\
\hline 10 & 8.530 & 8.111 & 7.722 & 7.360 & 6.710 & 6.144 \\
\hline 11 & 9.253 & 8.761 & 8.306 & 7.887 & 7.139 & 6.495 \\
\hline 12 & 9.954 & 9.385 & 8.863 & 8.384 & 7.536 & 6.814 \\
\hline 13 & 10.635 & 9.986 & 9.394 & 8.853 & 7.904 & 7.103 \\
\hline 14 & 11.296 & 10.563 & 9.899 & 9.295 & 8.244 & 7.367 \\
\hline 15 & 11.938 & 11.118 & 10.380 & 9.712 & 8.559 & 7.606 \\
\hline 20 & 14.878 & 13.590 & 12.462 & 11.470 & 9.818 & 8.514 \\
\hline 30 & 19.600 & 17.292 & 15.372 & 13.765 & 11.258 & 9.427 \\
\hline 40 & 23.11 & 19.79 & 17.16 & 15.05 & 11.93 & 9.78 \\
\hline 50 & 25.73 & 21.48 & 18.26 & 15.76 & 12.23 & 9.92 \\
\hline 60 & 27.68 & 22.61 & 18.93 & & & \\
\hline 70 & 29.12 & 23.39 & 19.34 & & & \\
\hline 80 & 30.20 & 23.91 & 19.60 & & & \\
\hline 90 & 31.00 & 24.26 & 19.75 & & & \\
\hline 100 & 31.60 & 24.50 & 19.85 & & & \\
\hline & & & & & & \\
\hline
\end{tabular}

Fonte: Adaptado de Matern, S. ${ }^{3}$ e Gitman, L. J. ${ }^{37}$

Para o cálculo de fator de atualização foi usada a fórmula: $\quad \sum_{n=1}=\frac{1-(1+r)^{-n}}{r}$,

onde $\mathrm{N}$ é a duração do ciclo de vida em anos, $\mathrm{n}$ o ano do evento e $\mathrm{r}$ a taxa real de juros.

A fórmula para o cálculo do CCV é muito didática, pois reúne todos os fatores de custo que precisam ser considerados em um estudo de custo, em especial em aplicações comparativas. Ela tem sido muito utilizada em artigos internacionais, dos 
quais deve ser citado o artigo Life Cycle Cost (LCC) - A New Approach to Materials Selection, de Matern, $\mathrm{S}^{3}$

$\mathrm{Na}$ prática, os economistas mais acostumados a trabalhar o CCV visando avaliar oportunidades de investimento, fazem o cálculo do custo contábil de cada fator de custo considerado no seu estudo, ao longo do tempo de avaliação usando a inflação e, posteriormente, estes fatores de custo corrigidos serão trazidos ao valor presente de acordo com as taxas de oportunidade, de forma a poder avaliar qual ou quais unidades em estudo são mis vantajosas financeiramente, é importante salientar que estas duas sistemáticas são compatíveis aos objetivos da CCV e levam a resultados semelhantes.

A taxa de inflação mais comumente utilizada é o Índice de Preços ao Consumidor (IPCA) calculada pelo Instituto de Pesquisa Econômica Aplicada (Ipea). Como taxa nominal de juros é utilizado, principalmente, o Sistema Especial de Liquidação e de Custódia (Selic), estabelecida pelo Comitê de Política Monetária (Copom), do Banco do Brasil. 


\subsection{FABRICAÇÃO E REFINO DO AÇÚCAR DE CANA}

A cana-de-açúcar é uma gramínea tropical, da mesma família do sorgo e do milho. Alguns historiadores acreditam que ela seja natural da Birmânia, China e Índia. O registro mais antigo do seu cultivo é de origem hindu, datado de 3.000 anos, aproximadamente. A obtenção do açúcar se deu entre os séculos IV e V. D.C. ${ }^{38}$

Inicialmente, o caldo de cana era evaporado em pratos de argila, aquecidos sobre fogo direto. A partir do século $\mathrm{V}$, os árabes desenvolveram moinhos de pedra para a obtenção do caldo, a clarificação, a cristalização e o refino do açúcar. Eles também introduziram o açúcar na Europa, via Espanha, no final do século VII.

Até o final do século XIX, a evaporação do caldo de cana era feita em tachos abertos e com fogo direto. Posteriormente, estes tachos passaram a trabalhar fechados, aquecidos com vapor e, em alguns casos, com pequeno vácuo.

O grande salto tecnológico na produção de açúcar se deu por volta de 1830, na Louisiana, EUA, por Norbert Rillieux. Ele desenvolveu as bases para a concentração do caldo de cana para produção de açúcar tal como é utilizado até hoje. ${ }^{39}$

\subsubsection{Processo de fabricação do açúcar de cana}

O século $X X$ foi marcado por um grande esforço de diversos países para o desenvolvimento de variedades de cana com características específicas; a mecanização do plantio, colheita e transporte e o desenvolvimento da produção, com ganhos expressivos em qualidade, questões ambientais e econômicas.

A cana-de-açúcar pode ser plantada em climas desde o temperado até o tropical, admite até três colheitas e entre o plantio e a primeira colheita passam-se 18 meses, aproximadamente. Quarenta e quatro por cento do território brasileiro apresenta características de solo e clima adequados ao seu plantio. A colheita de cana-de-açúcar pode ser manual ou mecanizada e uma vez colhida ela é transportada até as usinas em caminhões.

A Figura 7 apresenta o diagrama de fluxo da produção de açúcar, em resumo. 


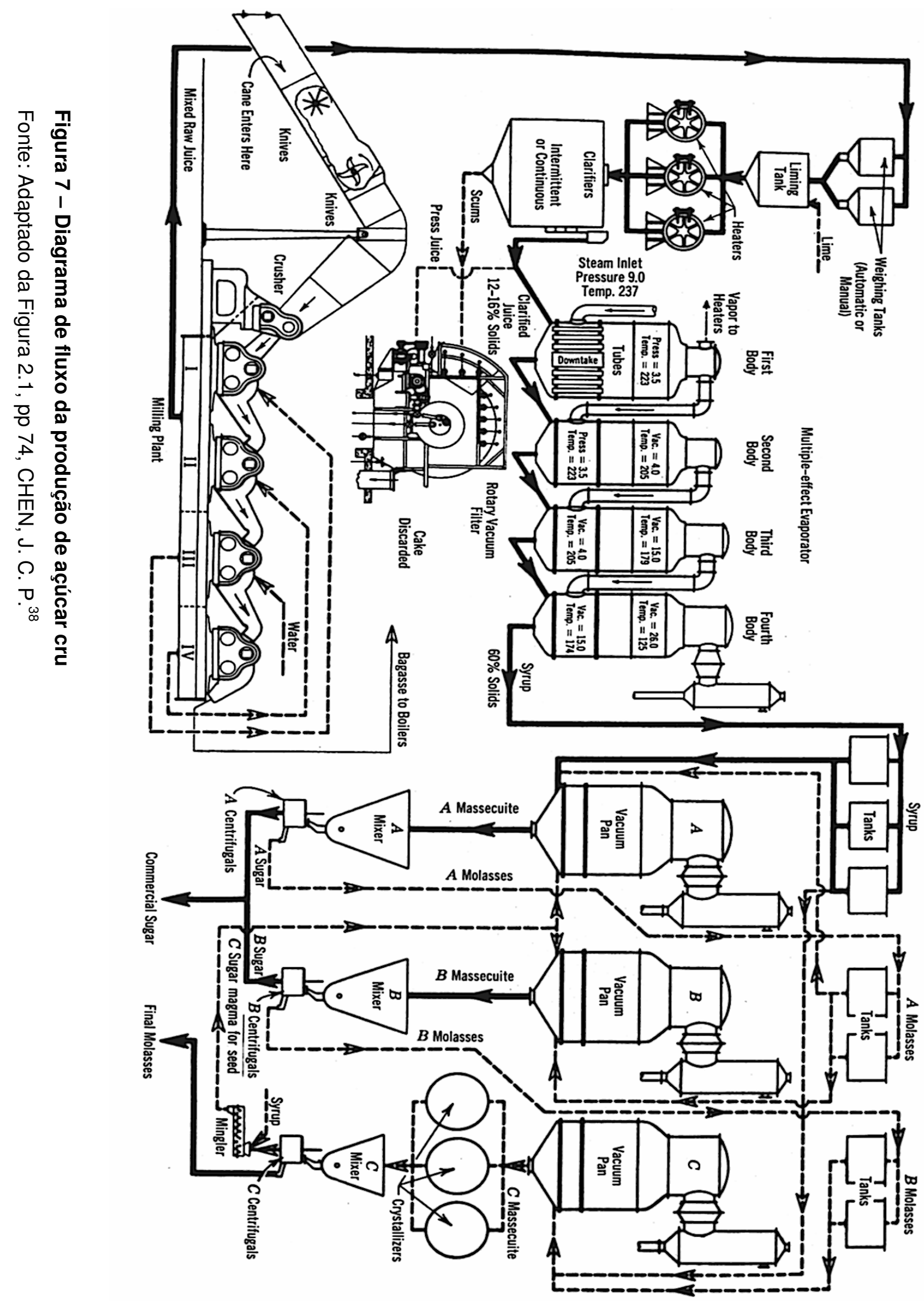




\subsubsection{Extração do caldo}

A extração do caldo de cana através das moendas é a primeira etapa da produção de açúcar cru. Inicialmente a cana é preparada para moenda mediante lâminas giratórias que fragmentam os calmos em pedaços pequenos; ou através de desintegradores, que diminuem os pedaços de cana, sem, contudo, extrair o caldo. Pode também ser usada a combinação destas duas técnicas. A moenda consta de unidades múltiplas que utilizam a combinação de três rolos, através dos quais passam, sucessivamente, a cana prensada ou bagaço. Para ajudar a extração de caldo aplicam-se aspersões de água ou caldo diluído sobre a camada de bagaço que sai de cada unidade da moenda, antes de entrar na próxima unidade. Este processo conhecido como embebição, pode apresentar muitas modificações. Nas práticas de moagem mais eficientes, mais que 95\% do teor de açúcar presente na cana passa para o caldo. Esta porcentagem é conhecida como "extração de sacarose" (Pol da extração) ou, mais simplesmente, a "extração".

Em vários países produtores de açúcar, desde o início da década de 1960 tem-se adotado a técnica de difusão para extração do caldo de cana.

O bagaço que sai da última prensa contém o açúcar não extraído, fibra e 45$55 \%$ de água. Este material é usado como combustível, na fabricação de placas prensadas para paredes, papel, cama para gado ou para vários outros usos secundários. O diagrama de processo apresentado na Figura 7 apresenta um conjunto de moagem com dois jogos de lâminas giratórias, uma fragmentadora de dois rolos e quatro jogos de moenda com três rolos cada um.

\subsubsection{Purificação do caldo: Clarificação}

O caldo de cana proveniente da seção de extração é turvo e apresenta cor bege esverdeada. $O$ processo de clarificação desenvolvido para remover as impurezas tanto solúveis como insolúveis emprega, de forma praticamente mundial, cal e calor como agentes clarificantes. A quantidade de cal adicionada, em geral $500 \mathrm{~g}$ de cal por tonelada de cana, neutraliza a acidez natural do caldo, formando 
sais insolúveis de cálcio, em geral fosfatos. O aquecimento do caldo alcalinizado até o ponto de ebulição ou pouco acima, coagula as albuminas, graxas, ceras e gomas. O precipitado grosseiro formado é separado por sedimentação. O caldo parcialmente clarificado é filtrado em tambores rotativos. O caldo filtrado é então clarificado em uma prensa. As borras separadas nas diferentes fases citadas anteriormente são usadas como fertilizante. O suco clarificado, límpido e ligeiramente amarelado segue para a seção de evaporação.

\subsubsection{Evaporação}

Tendo em vista o objetivo deste trabalho, este assunto receberá uma abordagem mais detalhada no próximo capítulo.

\subsubsection{Cristalização}

O caldo de cana sai dos evaporadores com uma concentração de 60 a 70Bix quando for usado para a produção de açúcar demerara e de 50 a 60ㅂix para açúcar clarificado.

A cristalização tem lugar em cozedores a vácuo, que funcionam como evaporadores de simples-efeito, onde o caldo de cana continua a ser evaporado até saturar-se de sacarose. Neste momento são adicionadas "sementes" a fim de que sirvam de núcleos para os cristais de sacarose. O crescimento dos cristais continua até que encham completamente o cozedor. Os cristais originais crescem e são formados novos cristais também, de maneira que quando o tacho está totalmente cheio, todos os cristais têm o tamanho desejado e formam uma massa densa, conhecida como "massa cozida". Neste ponto, o conteúdo do tacho é descarregado em um misturador ou cristalizador.

A ebulição das massas cozidas e dos méis - denominação dada à fase líquida, constituída de substâncias não açúcares e um pouco de sacarose - acontece 
em sistemas de ebulição escolhidos para ajustarem-se às varias condições de processo.

\subsubsection{Centrifugação ou purga: reebulição dos méis}

A massa cozida proveniente do misturador ou do cristalizador chega às centrífugas. As paredes laterais possuem lâminas que contém de 60 a 90 perfurações por $\mathrm{cm}^{2}$. O tambor gira a uma velocidade que oscila entre 1000 e 1800 rotações por minuto. $O$ revestimento perfurado retém os cristais de açúcar que podem ser lavados com água pura, caso seja necessário. O licor mãe, o "mel" passa através do revestimento devido à força centrífuga exercida, que varia de 500 a 1800 vezes a força da gravidade. Depois que o açúcar é purificado, a centrífuga é descarregada e recebe mais uma carga de massa cozida.

Com objetivo de se obter um açúcar cada vez mais puro, as centrífugas modernas trabalham com velocidades cada vez maiores e operam de forma contínua.

No sistema de três cristalizações mostrado na Figura 7, a primeira ebulição do caldo de cana concentrado produz açúcar e mel A, que retorna ao cozedor a vácuo para ferver sobre um "pé" de massa cozida (B), que por sua vez produz uma segunda carga de cristais. $O$ açúcar $B$ é misturado com o açúcar A para constituir a produção comercial da usina. O mel $\mathrm{B}$, ou de segunda, é impuro e volta a ser fervido sobre um "pé" de cristais de garapa para formar uma massa cozida "C", impura. Estas massas cozidas impuras permanecem vários dias nos cristalizadores, onde se esfriam e são mantidas em movimento por intermédio de braços mecânicos. $O$ açúcar "C" é misturado ao caldo concentrado e é utilizado como "semente" de cristalização para as massas cozidas A e B. Os "méis" ou "melaços" finais ou residuais, um material denso e viscoso que contém, aproximadamente, 1/3 de sacarose, 1/5 de açúcares redutores e o restante na forma de cinzas, compostos orgânicos não açúcares e água. Eles servem como base para a alimentação de gado, fabricação de álcool, produção de levedura ou uma grande variedade de subprodutos. 


\subsection{EVAPORAÇÃO DO CALDO DE CANA}

O caldo clarificado que flui dos decantadores é uma solução de cor variável entre o amarelo e o âmbar, quente, geralmente brilhante, com um teor de sólidos solúveis variável, que depende do processo adotado para a fabricação de açúcar e de álcool e do processo de extração (entre 14 e 17ºBrix). ${ }^{38,39}$

Nessas condições, o caldo clarificado chega à evaporação com mais que $80 \%$ de água, numa temperatura de $95^{\circ} \mathrm{C}$, aproximadamente.

É sempre importante que a temperatura do caldo seja sempre tão próxima quanto possível da temperatura do vapor de alimentação do primeiro vaso de evaporação. Estando o caldo numa temperatura mais baixa, parte do calor latente do vapor é consumida para elevar o caldo à condição de ebulição. Se o caldo entra no evaporador a uma temperatura mais alta do que o ponto de ebulição, ocorre o "flash" ou uma auto evaporação e a quantidade de calor requerida para evaporar a água será menor que o equivalente de seu calor latente. Atualmente a maior parte das usinas passam o caldo clarificado em aquecedores antes da entrada no préevaporador ou no $1^{\circ}$ efeito no evaporador, elevando a sua temperatura $e$ melhorando assim a evaporação.

A concentração do caldo clarificado até a fase de cristalização da sacarose é feita em dois estágios:

a) evaporação propriamente dita, e,

b) cozimento.

A evaporação compreende a concentração do caldo clarificado até a obtenção de um líquido viscoso, denso, de cor variável entre o marrom e o caramelo, que ainda não mostra sinais de cristalização, que se denomina xarope.

É habitual encontrar nas usinas de açúcar o seguinte critério na evaporação do caldo de cana:

a) concentração do caldo para obter o açúcar demerara: 60 a 70Brix;

b) concentração do caldo para obter o açúcar refinado: 50 a 60ํำ.

É importante salientar que essas concentrações são influenciadas pelo Brix inicial do caldo clarificado, pelo tipo de evaporador utilizado, pressão de vapor e taxa de incrustação do evaporador, principalmente. 
O segundo estágio da concentração, ou seja, o cozimento, se inicia pouco antes do aparecimento de cristais no xarope, devendo se dar por encerrado quando da obtenção do máximo de cristalização da sacarose.

O produto final dessa operação é denominado massa cozida, formada por uma mistura de cristais de sacarose e mel. A separação dos cristais se dá por centrifugação. $O$ ponto de cristalização da sacarose se encontra entre os $70 \mathrm{e}$ 80ํㅗix.

\subsubsection{Bases teóricas da Evaporação do Caldo de Cana}

Segundo Webre, apud Delgado, A. A., César, M. A. A. ${ }^{39}$, Norbert Rillieux, americano de descendência francesa, foi o primeiro estudioso da evaporação a definir os seus princípios básicos, por volta de 1830, na Louisiana, EUA.

Antes dos trabalhos de Rillieux divulgados em 1843, o processo de concentração do caldo até a condição de massa cozida acontecia em uma única etapa, em um aparelho de baixo vácuo, o qual era simplesmente um tacho com uma camisa de vapor (tacho HOWARD).

A primeira patente de Rillieux mostra dois tachos de HOWARD, conectados em série, sendo que o primeiro tacho operava como um evaporador, fornecendo vapores ao segundo tacho, onde se elaborava a massa cozida.

A segunda patente de Rillieux, desenvolvida em 1848, refere-se ao aproveitamento dos vapores de vários tachos. Rillieux mudou o desenho dos vasos de camisas duplas, passando a trabalhar com três ou quatro recipientes cilíndricos dispostos verticalmente e em posições paralelas, construídos em chapas de ferro. $\mathrm{O}$ vapor circulava de um vaso a outro por meio de tubos, controlados por válvulas. Independente do sucesso dos trabalhos de Rillieux, o pré-evaporador só passou a ser usado na década de 1880, por Leka e Pauly, apud Delgado, A. A., César, M. A. A. ${ }^{39}$.

Desde então, os estudos para o aperfeiçoamento do sistema da evaporação do caldo de cana, os progressos verificados, apesar de não se constituírem em modificações radicais de operação, tem sido a consolidação dos postulados de Rillieux, conhecidos por "Princípios da Evaporação". 40,41,42 


\subsubsection{Princípios da Evaporação de Rillieux}

Os estudos de RILLIEUX levaram-no a estabelecer os três princípios da evaporação em múltiplo efeito, que são: ${ }^{39}$

\subsubsection{Primeiro Princípio}

"Em um evaporador de múltiplo efeito, cada quilograma de vapor usado no primeiro vaso (primeiro efeito) evaporará tantos quilogramas de água quantos forem os vasos (ou efeitos)".

Diante desse princípio tem-se o seguinte:

a) evaporador simples efeito: $1 \mathrm{~kg}$ de vapor evapora $1 \mathrm{~kg}$ de água;

b) evaporador duplo efeito: $1 \mathrm{~kg}$ de vapor evapora $2 \mathrm{~kg}$ de água;

c) evaporador triplo efeito: $1 \mathrm{~kg}$ de vapor evapora $3 \mathrm{~kg}$ de água;

d) evaporador com $\underline{n}$ efeitos: $1 \mathrm{~kg}$ de vapor evapora $\underline{n} \mathrm{~kg}$ de água.

Por este princípio verifica-se que o consumo de vapor se restringe apenas ao utilizado no primeiro efeito e que quanto maior for o número de efeitos, tanto menor será o consumo de vapor. Na prática, o número de efeitos se restringe a 4 ou 5 , devido a outras considerações técnicas e econômicas.

\subsubsection{Segundo Princípio}

"A extração de vapor de qualquer unidade de um evaporador de múltiplo efeito, para ser usado em outro setor da fábrica, (sangria) conduz a uma economia que será igual ao número de quilogramas de vapor assim extraído, dividido pelo número de efeitos do conjunto e multiplicado pelo número de ordem que o efeito ocupa". 
Considerando $\mathrm{W}$ o peso do vapor, $\mathrm{M}$ o número de efeitos e $\mathrm{N}$ o número de ordem que o vaso ocupa no conjunto de evaporação, a economia de vapor EV será igual a:

$$
E V=W \frac{N}{M}
$$

Por exemplo, a retirada de $1 \mathrm{~kg}$ de vapor do primeiro efeito de um quádruplo efeito implica numa economia equivalente a $1 / 4$ do vapor usado, ou seja:

$$
\mathrm{EV}_{10}{ }^{\text {e efeito }}=1 \quad \frac{1}{4}=\frac{1}{4}
$$

Caso a retirada de $1 \mathrm{~kg}$ de vapor aconteça no terceiro efeito, a EV seria:

$$
\mathrm{EV}_{3^{\mathrm{e}} \text { efeito }}=1 \quad \frac{3}{4}=\frac{3}{4}
$$

A aplicação, na prática, deste Princípio leva as usinas a fazerem "sangrias" no primeiro e segundo efeitos, principalmente para fazerem aquecimento de caldo ou para outros fins. Como a temperatura do vapor decresce nos últimos efeitos, a prática de sangria de vapor dessas unidades é pouco comum.

\subsubsection{Terceiro Princípio}

"Em todo aparelho no qual se condensa vapor, é necessário extrair continuamente a acumulação de gases incondensáveis. Por "gases incondensáveis" entende-se, principalmente, ar. Como o ar é mais denso que o vapor, ele fica próximo à superfície superior da calandra". Se estes gases não forem retirados continuamente, eles podem interromper toda a evaporação, rapidamente. Em um $3^{\circ}$ ou $4^{\circ}$ efeitos em poucos minutos. Isto se deve porque a temperatura do vapor é correspondente à sua pressão parcial. Como a pressão parcial do vapor é proporcional ao seu volume, ao aumentar o volume dos gases incondensáveis, a pressão parcial do vapor que provoca a evaporação vai diminuir, comprometendo todo o processo de evaporação. 


\subsubsection{Termodinâmica aplicada à evaporação}

No estudo da evaporação, alguns conceitos termodinâmicos são necessários, conforme será mostrado a seguir:

\subsubsection{Transmissão de Calor}

Quando o vapor toca a superfície externa de um tubo que está a uma temperatura menor do que a sua, ele aquece o líquido que está no seu interior. Em conseqüência disso, o vapor condensa-se e cede o seu calor latente. Assim, o trabalho de um evaporador está baseado na transferência do calor latente do vapor para o caldo em ebulição.

Chama-se "vapor" a água em estado gasoso a uma pressão maior do que a atmosférica. Nas usinas de açúcar, o vapor é obtido em caldeiras, utilizando-se bagaço como combustível.

Por "gases" entendem-se os vapores obtidos a uma pressão menor do que a atmosférica.

Nos evaporadores de múltiplos efeitos, "vapor" é todo aquele que alimenta o primeiro efeito e que resulta da evaporação deste, pois neste vaso, a pressão é geralmente superior à atmosférica. Nos demais efeitos se têm "gases", pois eles são produzidos em condição de um vácuo, que cresce nas últimas unidades do conjunto de evaporação.

\subsubsection{Calor Específico}

Calor específico de uma substância é a quantidade de calor necessária para elevar a temperatura de uma unidade de massa desta mesma substância, em $1^{\circ} \mathrm{C}$. As unidades mais usuais para a medição de calor são: caloria (cal); quilocaloria (kcal) e Unidades Térmicas Britânicas (BTU). 
Quando, por exemplo, se diz que o calor específico do caldo de cana a 15ํㅜㅅㅜ é 0,97, entende-se que um grama de caldo exige 0,97 calorias para passar de $\mathrm{t}^{\circ} \mathrm{C}$ à $\left(\mathrm{t}^{\circ}+1\right)^{\circ} \mathrm{C}$. Neste caso é expresso como cal $/ \mathrm{g}$.

\subsubsection{Calor sensível}

Calor sensível é aquele decorrente de uma variação de temperatura, podendo ser identificado por uma modificação na escala de um termômetro. O calor sensível não altera o estado físico dos corpos, apenas a sua temperatura.

O calor sensível da água, por exemplo, é a quantidade de calor que se deve transferir a $1 \mathrm{~g}$ ou a $1 \mathrm{~kg}$ de água, submetida a pressão $\mathrm{P}$, para elevar a sua temperatura desde $0^{\circ} \mathrm{C}$ até a temperatura de ebulição.

O calor sensível necessário para elevar $1 \mathrm{~kg}$ de água pura, a pressão de uma atm, de $0^{\circ} \mathrm{C}$ a $100^{\circ} \mathrm{C}$ é igual a $100,0 \mathrm{kcal} / \mathrm{kg}$.

\subsubsection{Calor Latente}

Calor latente é aquele que produz uma modificação no estado físico de uma substância, sem modificar a temperatura. É, pois, o calor que é absorvido ou desprendido por um corpo durante as mudanças de estado a que está submetido.

Por exemplo, o calor latente de vaporização da água a $100^{\circ} \mathrm{C}$, a pressão de $1 \mathrm{~kg} / \mathrm{cm}^{3}$, é de $538,9 \mathrm{kcal} / \mathrm{kg}$.

\subsubsection{Calor total de vaporização}

Entende-se por calor total de um vapor, a soma do calor sensível mais o calor latente de vaporização. Compreende o calor necessário para converter, por exemplo, $1 \mathrm{~kg}$ de água líquida a temperatura de $0^{\circ} \mathrm{C}$ e a pressão de $1 \mathrm{~kg} / \mathrm{cm}^{3} \mathrm{em}$ 
vapor seco a mesma pressão, ou seja, usando os valores apresentados em 2.6.3.3 e 2.6.3.4, temos:

$$
100,0+538,9=638,9 \mathrm{kcal} / \mathrm{kg}
$$

\subsubsection{Transmissão de Calor em um Evaporador}

Um evaporador de usina é constituído, basicamente, por uma calandra tubular, a qual serve como aparelho de intercâmbio de temperatura. O vapor de aquecimento envolve os tubos externamente e o caldo a ser evaporado percorre o interior dos tubos.

Quando dois fluídos com temperaturas diferentes estão de cada lado de uma parede, a quantidade de calor transmitida de um ao outro tem a seguinte expressão:

$$
\mathrm{Q}=\mathrm{U} \cdot \mathrm{S} \cdot \Delta \mathrm{t}
$$

Onde:

$\mathrm{Q}=$ quantidade de calor transmitido (kcal);

$\mathrm{U}=$ coeficiente total de transmissão de calor $\left(\mathrm{kcal} / \mathrm{m}^{2} / \mathrm{h} / \stackrel{\circ}{\circ}\right)$;

$\mathrm{S}=$ superfície de troca de calor (superfície interna para os tubos em $\mathrm{m}^{2}$ );

$\Delta \mathrm{t}=$ diferença de temperatura entre os fluídos (vapor e caldo)

O coeficiente total de transmissão de calor (U) é calculado pela expressão:

$$
U=\frac{1}{\frac{1}{h_{0}}+\frac{e}{c}+\frac{1}{h_{1}}}
$$

Onde:

$\mathrm{h}_{\mathrm{o}}=$ coeficiente de transmissão de calor de película do fluído quente à parede $\left(\mathrm{kcal} / \mathrm{m}^{2} / \mathrm{h} / \stackrel{\circ}{ } \mathrm{C}\right)$;

$\mathrm{h}_{1}=$ coeficiente de transmissão de calor de película do fluído da parede ao fluído frio ( $\left.\mathrm{kcal} / \mathrm{m} / \mathrm{h} /{ }^{\circ} \mathrm{C}\right)$;

$\mathrm{e}=$ espessura da parede $(\mathrm{m})$;

$\mathrm{C}=$ condutividade térmica do material que compõe a parede $(\mathrm{kcal} / \mathrm{m} / \mathrm{h} / \stackrel{\circ}{ } \mathrm{C})$.

O coeficiente $U$ compreende as resistências térmicas das duas películas que se formam junto às paredes metálicas e das paredes sólidas banhadas pelos dois fluídos, responsáveis por essas películas.

Desta forma, comprova-se que o valor de $U$ depende da grandeza dos coeficientes $h_{0}, h_{1}, c$, e ou, na prática, do menor valor desses coeficientes. 
A Figura 8 mostra as contribuições relativas aproximadas desses parâmetros, conforme demonstrado por Lustenader, E. L., Staub, F. W. ${ }^{43}$

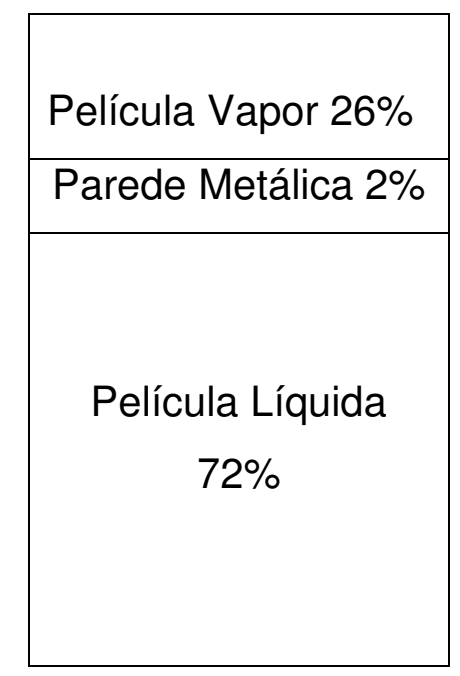

Figura 8 - Fatores que afetam a transferência de calor na evaporação de líquidos Fonte: Adaptado de LUSTENADER, E. L., STAUB, F. W. ${ }^{43}$

Nesse sentido, o tipo de material que compõe a parede do tubo contribui pouco na eficiência térmica do processo de troca de calor, conforme mostrado na Tabela 7, extraída da publicação Stainless Steel for Evaporators/ Concentrators ${ }^{44}$.

Tabela 7 - Efeito da Condutividade do Metal no Coeficiente Total de Transmissão de Calor "U”"

\begin{tabular}{|l|c|c|c|c|}
\hline \multicolumn{1}{|c|}{ Material } & $\begin{array}{c}\text { Coeficiente de transmissão } \\
\text { de Calor de Película } \\
\mathrm{BTU} / \mathrm{hr} / \mathrm{ft}^{2} / \stackrel{\circ}{ } \mathrm{F}\end{array}$ & $\begin{array}{c}\text { Condutividade } \\
\text { térmica } \\
\mathrm{BTU} / \mathrm{hr} / \mathrm{ft}^{2} /{ }^{\circ} \mathrm{K} / \mathrm{in}\end{array}$ & $\begin{array}{c}\mathrm{U}^{* *} \\
\mathrm{BTU} / \mathrm{hr} / \mathrm{ft}^{2} / \\
\text { of }\end{array}$ \\
\hline Cobre & $\begin{array}{c}\mathrm{h}_{\mathrm{o}} \\
300\end{array}$ & $\begin{array}{c}\mathrm{h}_{1} \\
1000\end{array}$ & 2680 & 229 \\
\hline Alumínio & 300 & 1000 & 1570 & 228 \\
\hline Aço-Carbono & 300 & 1000 & 460 & 223 \\
\hline Aço-Inoxidável $^{*}$ & 300 & 1000 & 105 & 198 \\
\hline
\end{tabular}

* Aço Inox série 300 (Austenítico)

* * Espessura da parede igual a 0,7874 in $(2,0 \mathrm{~mm})$

Fonte: Adaptado da Tabela 2, da publicação Stainless Steel for Evaporators and Concentrators ${ }^{44}$ 
A partir dos dados apresentados nesta tabela, pode-se observar que mesmo sendo a condutividade térmica do aço carbono $338 \%$ maior que a do aço inox, 0 coeficiente total de transferência de calor é apenas 13\% maior.

Utilizando os dados da Tabela 7, pode-se constatar também que um tubo de aço carbono com 2,65 mm de espessura apresenta um valor de coeficiente total de transmissão de calor "U" apenas 5\% maior que um tubo em inox com 1,20 mm de espessura.

Com relação ao coeficiente total da transferência de calor, cabe finalmente considerar a influência das incrustações que se formam nos tubos dos evaporadores. Estas incrustações, que podem se formar tanto externamente quanto internamente aos tubos, por terem baixíssima condutividade térmica, afetam negativamente a eficiência térmica de um evaporador. Tendo em vista a constante variação da sua natureza e espessura, torna-se difícil determinar exatamente a sua magnitude e influência. Daí a importância de se trabalhar com evaporadores perfeitamente desincrustados.

Na fórmula anterior para o cálculo de "U”, o valor atribuído ao coeficiente de transmissão de calor da incrustação é sempre a menor grandeza e precisa ser somado aos demais coeficientes, ou seja, a fórmula para o cálculo de "U" passa a ter a seguinte composição.

$$
U=\frac{1}{\frac{1}{h_{0}}+\frac{1}{h_{1}}+\frac{1}{h_{2}}+\frac{e}{c}}
$$

Onde $\mathrm{h}_{2}=$ Coeficiente de transmissão de calor devido à incrustação.

No múltiplo efeito, o coeficiente total de transmissão de calor diminui com o decréscimo da pressão, devido à queda da temperatura e o aumento da concentração dos caldos.

Este coeficiente, conforme citado por vários autores, ${ }^{38,39,40,41}$ para um evaporador quádruplo-efeito pode variar conforme o apresentado na Tabela 8: 
Tabela 8 - Faixas de variação do coeficiente total de transmissão de calor

\begin{tabular}{|l|c|}
\hline \multicolumn{1}{|c|}{ Efeito } & $\begin{array}{c}\text { Faixa de Variação de "U" } \\
\mathrm{Kcal} / \mathrm{m}^{2} / \mathrm{h} / \stackrel{\circ}{ } \mathrm{C}\end{array}$ \\
\hline Primeiro & 1800 e 2950 \\
\hline Segundo & 1750 e 2350 \\
\hline Terceiro & 1150 e 1760 \\
\hline Quarto & 550 e 880 \\
\hline
\end{tabular}

Fonte: Citação de vários autores ${ }^{38,39,40,41}$

\subsubsection{Construção de um Evaporador Múltiplo-Efeito}

A evaporação do caldo de cana na maioria das usinas de açúcar do Brasil é realizada em evaporadores com quatro efeitos. Atualmente, de forma a aumentar a capacidade de evaporação, tem-se instalado um quinto vaso, conhecido como préevaporador e que na prática funciona como uma primeira etapa da evaporação, o que faz com que esta operação seja realizada em um quíntuplo-efeito.

Tanto o pré-evaporador como os vasos de múltiplo-efeito obedecem à mesma linha de construção.

Em linhas gerais, a construção de um múltiplo-efeito compreende a utilização das seguintes partes:

\subsubsection{Corpo do Evaporador}

Atendendo a facilidade de construção, manutenção e reposição, os corpos de um evaporador novo são essencialmente iguais na forma, altura e capacidade, exceção ao pré, que é sempre maior. 
Conforme a Figura 9, cada efeito é construído em chapas de aço-carbono de espessura variável de 10,00 a 20,00 mm, soldadas eletricamente na forma de um cilindro vertical e com uma altura superior ao dobro do diâmetro.

Cada corpo de um evaporador é formado por duas partes: cilindro superior ou câmara de evaporação e a calandra tubular ou câmara de aquecimento. Nessas duas câmaras são construídas entradas para inspeção, situadas próximo do espelho superior da calandra e medem de 50 a 80 centímetros de diâmetro.

A câmara de evaporação é fechada pelo domo e pelo vaso de segurança ou separador. O vaso de segurança é provido de saída lateral para o vapor resultante da evaporação do caldo na calandra. Ela é também dotada de diversas lunetas de vidro, que permitem a observação do caldo em ebulição, dando uma idéia do nível do mesmo.

São também instalados nos diversos corpos dos evaporadores, manômetros, termômetros, indicadores de nível, etc. 


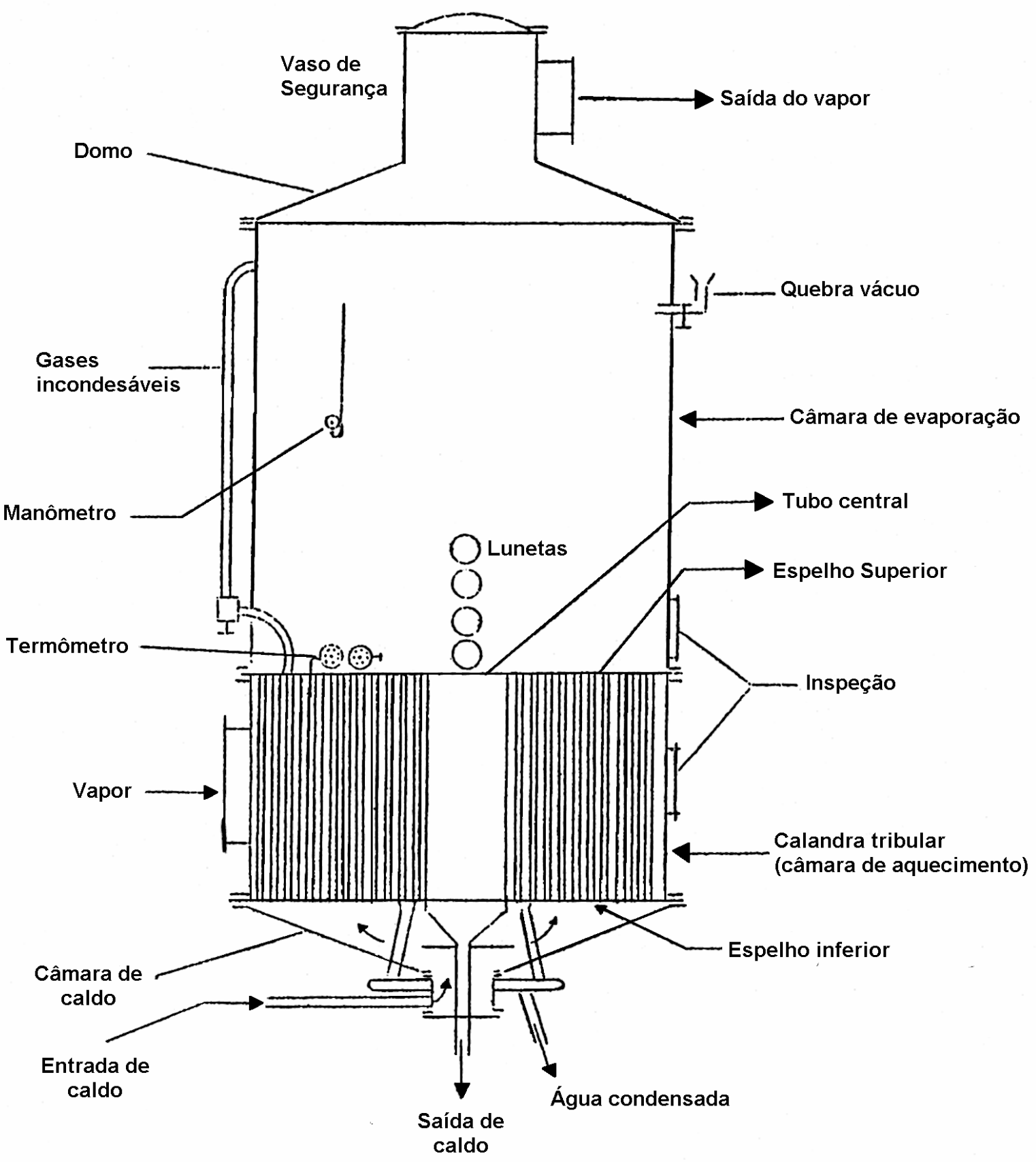

Figura 9 - Corpo de um vaso de um evaporador múltiplo-efeito

Fonte: Adaptado da Figura 137 de DELGADO, A. A., CESAR, M. A. A. ${ }^{39}$ 


\subsubsection{Câmara das evaporações}

A câmara das evaporações deve ser construída de forma a ficar com uma altura equivalente a 1,5 a 2,0 vezes a altura dos tubos.

Os vapores resultantes da ebulição do caldo na calandra ocupam todo o espaço dessa câmara, limitada superiormente pelo domo do vaso. Interiormente é limitada pelo espelho tubular da calandra.

O objetivo principal desta câmara é diminuir os riscos de arraste de gotículas de líquido em evaporação que se projetam junto com os vapores oriundos da ebulição do caldo.

O diâmetro do corpo também deve ser bem calculado, visto que poderá influir no arraste de gotículas.

De forma a evitar que as gotículas arrastadas cheguem à calandra do próximo efeito ou a seção de condensação dos vapores, utilizam-se os separadores de arraste, que serão citados adiante.

Os vapores desta câmara, alcançando o vaso de segurança central, saem por um tubo de grosso diâmetro que os conduzirá a calandra seguinte ou para o condensador, se for o caso do último corpo de um múltiplo-efeito.

\subsubsection{Calandra}

A calandra é formada basicamente por dois espelhos metálicos furados, os quais são interconectados por tubos metálicos, presos nos furos por mandrilamento, dentro de um corpo em aço carbono.

$\mathrm{Na}$ parte central dos dois espelhos, construídos geralmente de chapas com espessura de 31,63 mm, existe uma perfuração maior, interligada por um tubo de grosso diâmetro, denominado de tubo de circulação de caldo. O seu diâmetro corresponde, no geral, de $1 / 4$ a 1/8 do diâmetro interno da calandra.

Em alguns equipamentos este tubo central é substituído por passagens laterais, constituindo-se o que se conhece por calandra flutuante. Outros projetos 
têm incluído uma série de tubos de maior diâmetro, distribuído em toda a superfície da calandra.

Os tubos da calandra podem ser de aço carbono, de cobre, de latão ou, mais recentemente, de aço inoxidável.

Mais recentemente, de forma a obter equipamentos mais compactos, tem-se optado pelo uso de tubos mais longos, assim, tem sido construídos evaporadores com tubos de até 5 a $6 \mathrm{~m}$ de comprimento.

O comprimento dos tubos em um evaporador clássico varia de 1,5 a 3,0 m, recomendando-se dotá-los de 5 a $6 \mathrm{~mm}$ a mais em cada extremidade para efeito de um melhor mandrilamento.

A utilização de tubos mais longos no pré-evaporador e nos primeiros efeitos não causa nenhum inconveniente, pois, nesses vasos, o caldo é mais diluído, podendo ascender por eles com mais facilidade.

Nos últimos efeitos, onde o xarope torna-se mais viscoso, os tubos devem ser mais curtos. Com esta providência, a taxa de evaporação pode ser mantida a bom nível.

De modo geral, o diâmetro externo mais usual dos tubos de um múltiplo efeito é de 38,10 mm. Por vezes, é ainda utilizado o diâmetro externo igual a 31,75 mm.

A espessura da parede dos tubos varia em função do material de que são construídos.

A Tabela 9 apresenta as espessuras mais utilizadas para os diferentes materiais metálicos utilizados na fabricação de tubos.

Tabela 9 - Espessuras dos tubos de diferentes metais para uso em evaporadores

\begin{tabular}{|c|c|}
\hline Material & Espessura $\mathrm{mm}$ \\
\hline Aço carbono & 2,65 \\
\hline Aço inoxidável & 1,50 \\
& 1,20 \\
\hline \multirow{2}{*}{ Latão } & 2,00 \\
& 1,50 \\
\hline Cobre & 1,50 \\
\hline
\end{tabular}

Fonte: Dados extraídos de DELGADO, A. A., CESAR, M. A. A. ${ }^{39}$ 
Os tubos mandrilados nos espelhos da calandra obedecem a uma disposição enxadreizada. Segundo Hugot E. ${ }^{41}$, esta disposição permite a colocação de um maior número de tubos por unidade de superfície de espelho e uma mesma distância entre os tubos, conforme mostrado na Figura 9. Neste arranjo, os tubos ficam alinhados segundo três direções a $120^{\circ}$ uma da outra. As três perfurações definem um triângulo eqüilátero, cujos ângulos internos são de 60․

A distância de centro a centro entre dois tubos é conhecida por "passo", P. "P" pode ser calculado, conforme a equação:

$$
h=\sqrt{ } 3 / 2 . P
$$

Admitindo-se, por exemplo, $\mathrm{d}_{\mathrm{e}}=38,10 \mathrm{~mm}$, P será igual a 51,4 mm Nessas condições, a distância entre dois tubos será de 13,3 mm. 


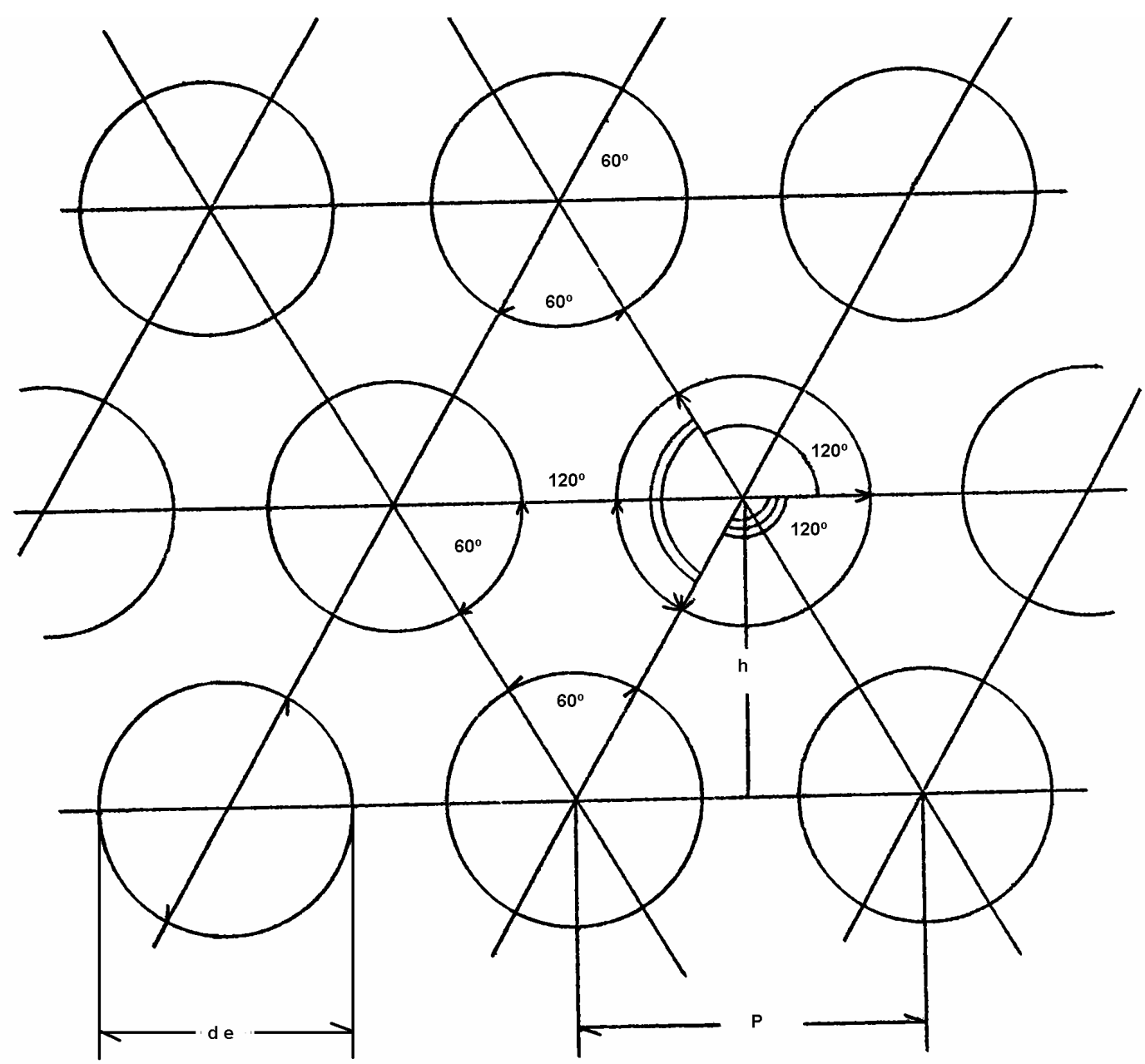

Figura 10 - Disposição dos tubos no espelho da calandra de um evaporador

Fonte: DELGADO, A. A.,CESAR, M. A. A. ${ }^{41}$

\subsubsection{Distribuição do Vapor de Aquecimento nas Calandras}

O vapor é admitido pela parte lateral da calandra. Em aparelhos de pequena capacidade, uma entrada de vapor é suficiente. Em aparelhos maiores, duas ou mais entradas permitem uma melhor e mais rápida distribuição do vapor de aquecimento por toda a calandra. Alguns construtores utilizam-se de placas metálicas, colocadas internamente na calandra com a finalidade de dar uma melhor distribuição do vapor, conforme mostrado esquematicamente na Figura 11, detalhe "a".

Estas placas são especialmente úteis no pré-evaporador, pois evitam o possível dobramento dos tubos situados logo à frente destas entradas. Esta prática 
é especialmente útil quando são usados tubos longos em aços inoxidáveis com $1,20 \mathrm{~mm}$ de espessura.

Pode-se também fazer a retirada de algumas linhas de tubos, de forma a facilitar a circulação do vapor pela calandra, vindo-se a formar o que se chama por "corredores de vapor", conforme mostrado na Figura 11, detalhe "b".

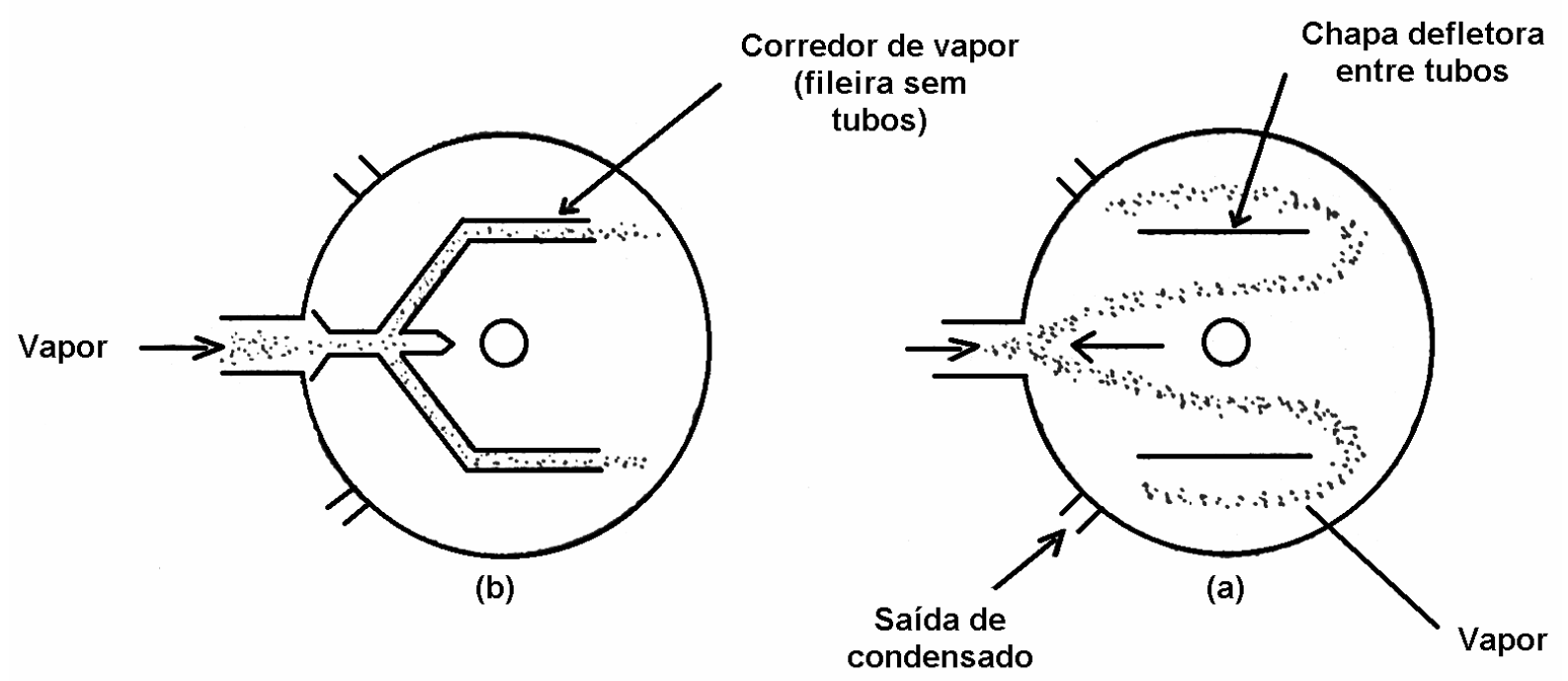

Figura 11 - Distribuição do vapor na calandra

Fonte: DELGADO, A. A., CESAR, M. A. A. ${ }^{39}$

\subsubsection{Circulação dos vapores em um múltiplo-efeito}

O vapor proveniente da caldeira alimenta a calandra do $1^{\circ}$ efeito fazendo com que o caldo presente nos tubos entre em ebulição.

O vapor proveniente desta ebulição é encaminhado à unidade de mesmo tipo do segundo efeito. O vapor, resultante da evaporação do caldo do segundo efeito é encaminhado, do mesmo modo, à calandra do terceiro efeito e, assim, sucessivamente, até que os vapores do último vaso cheguem ao condensador, conforme mostrado esquematicamente na Figura 12.

O vapor, saindo pela parte central e superior do corpo, passando pelo separador de arraste e pelo vaso de segurança, segue à calandra seguinte através 
de uma tubulação cujo diâmetro é calculado considerando quantidade, velocidade e pressão do vapor.

Como o vácuo cresce do segundo para os últimos vasos, a velocidade dos vapores do caldo em evaporação também aumenta e, nessas condições, o diâmetro da tubulação de condução desses valores também deve crescer progressivamente.

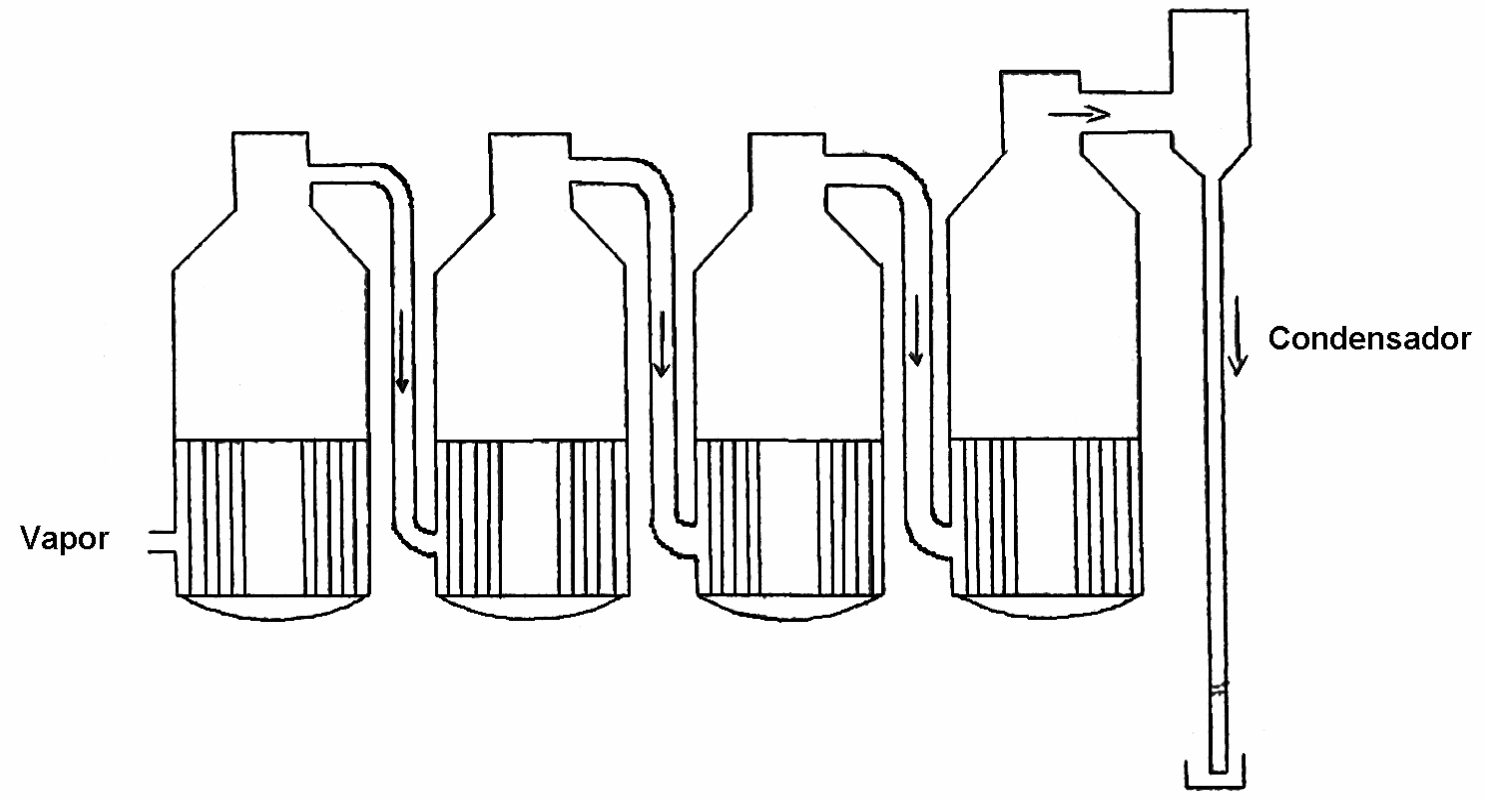

Figura 12 - Circulação do vapor num quádruplo-efeito

Fonte: DELGADO, A. A., CESAR, M. A. A. ${ }^{39}$

\subsubsection{Remoção de "Condensados"}

O vapor, cedendo o seu calor latente de vaporização ao caldo em circulação na calandra, condensa-se, mantendo-se, praticamente, na mesma temperatura do vapor original. Isto acontecendo, no final de certo tempo a quantidade de água vai aumentando, podendo chegar a obstruir o espaço de aquecimento. Desta maneira, há necessidade de se retirar continuamente esta água de condensação para o bom funcionamento do sistema de evaporação. 
A drenagem destes condensados pode ser feita de várias maneiras. As mais comuns são: purgadores, bomba de ar úmido, drenos baroméricos, sifões em "U" e vasos de expansão. Ver Figura 9, página 96.

Os "condensados" podem ser utilizados para aquecimento de caldo ou outras utilidades que precisem de calor.

\subsubsection{Remoção de gases incondensáveis}

As calandras dos evaporadores de um múltiplo-efeito estão sempre providas de tubos chamados "amoniacais", os quais têm por finalidade extrair os gases incondensáveis.

Esta operação é muito importante, pois esses gases diminuem grandemente a eficiência da evaporação, chegando em certos casos a danificá-las, conforme especificado no Terceiro Principio de Rillieux.

Esses "gases" contêm de ar, admitido pelas juntas entre as diversas peças e amoníaco, derivado da decomposição de substâncias nitrogenadas. A maioria dos gases incondensáveis é constituída por ar quente, que é mais pesado que o vapor, se acumula na parte inferior da calandra. $O$ amoníaco, mais leve que o ar, acumulase sob o espelho superior. A extração deste gás é necessária pois ele ataca as partes externas dos tubos, corroendo-os e furando-os.

A extração desses gases não é difícil, podendo ser feita de diferentes maneiras, conforme o efeito em questão. Ver Figura 9, página 96.

\subsubsection{Vaso de Segurança}

Todos os efeitos de um evaporador possuem na parte superior e central do domo uma peça denominada de vaso de segurança ou separador de arraste.

Esta peça, construída sob os mais diferentes modelos, tem por finalidade dar vazão ao vapor que procede da parte inferior da câmara de evaporação, devendo estar equipada para reter as gotículas de líquido de um vaso ao outro. As pequenas 
gotículas de caldo em ebulição, muito leves, são arrastadas pelo vapor para o vaso seguinte. Como a taxa de arrastamento é diretamente proporcional ao vácuo, devido a maior velocidade do vapor, verifica-se que este fenômeno mais intenso nos últimos vasos.

Entre os modelos de vasos de segurança mais usuais estão o tipo clássico (guarda-chuva) e o separador centrífugo. No modelo clássico, os vapores depois de tocarem a parte superior do vaso, retornam para a parte inferior, para depois saírem pela tubulação que os conduzirá à calandra do vaso seguinte. Evidentemente, algum vapor que se condense na chapa defletora retorna na forma líquida para a calandra.

No separador centrífugo, o vapor tem mais possibilidade de tocar nas suas chapas laterais, o que garante uma maior retenção das gotículas.

Em decorrência da maior condição de vácuo, os arrastes mais intensos são produzidos no ultimo vaso do múltiplo-efeito. Para impedir que cheguem ao condensador, se interpõem entre este e o corpo do evaporador, na tubulação de vácuo, um separador-recuperador, para o qual existem vários modelos, sendo que nenhum alcança uma retenção de $100 \%$.

\subsubsection{Câmara de Caldo e Circulação}

O caldo que entra no primeiro efeito de um evaporador pela sua parte inferior ocupa todo o seu espaço interno, o que compreende o fundo do vaso até o espelho superior da calandra, por intermédio do interior dos tubos.

As câmaras de caldo dos diferentes vasos estão ligadas entre si por meio de tubos de passagem. Eles são de pequeno diâmetro e dispostos de tal modo que permitem regular manual ou automaticamente, um nível constante de caldo nas calandras dos diversos efeitos.

De qualquer forma que se oriente a circulação do caldo de uma calandra a outra, o importante é determinar o nível ótimo de trabalho do caldo no evaporador. De modo geral, o nível ideal do caldo na calandra deve estar a 1/3 da altura dos tubos. 


\subsubsection{Condensadores}

O vapor introduzido no $1^{\circ}$ efeito de um sistema de evaporação de múltiplosefeitos se condensa dentro deste $1^{\circ}$ vaso. De forma semelhante, o vapor do caldo produzido em cada efeito se condensa no vaso subseqüente. Desta forma, o vapor produzido no último efeito deve condensar-se a fim de manter as diminuições escalonadas de pressão e temperatura, que acontecem ao longo do $1^{\circ}$ até 0 último efeito do evaporador.

O vapor no último efeito, normalmente a uma pressão de aproximadamente $13 \mathrm{~cm} \mathrm{Hg}\left(57^{\circ} \mathrm{C}\right)$, está muito frio para ser usado no processo e precisa ser condensado por contato direto com água a uma temperatura inferior, em um condensador barométrico.

Um condensador barométrico é, resumidamente, um recipiente fechado onde o vapor proveniente do último efeito é condensado com água a uma temperatura entre 2,5 a $6,0^{\circ} \mathrm{C}$. Neste equipamento também são separados os gases "não condensáveis", provenientes do vapor ou da água fria.

A moderna indústria de equipamentos oferece uma grande variedade de "condensadores" com diferentes tamanhos e eficiências, mas todos operando com o mesmo princípio. 


\subsection{FORMAÇÃO DE INCRUSTAÇÕES NOS TUBOS DOS EVAPORADORES}

Durante o funcionamento de um múltiplo-efeito, os tubos podem sujar-se de duas maneiras:

\subsubsection{Depósitos externos}

Os tubos de troca de calor podem sujar-se externamente no pré-evaporador ou no primeiro efeito com óleo arrastado pelo vapor de escape; bem como nos demais efeitos pelas gotículas de caldo que foram arrastadas pelo vapor e que não foram devidamente retidas nos aparelhos para retenção e remoção de arraste.

Estes tipos de depósitos externos não têm merecido a atenção devida, mas prejudicam a transmissão de calor pelos tubos.

O primeiro tipo de depósitos pode ser evitado pela instalação de um separador de óleo no trajeto do vapor ou pela imersão da calandra com solução de soda cáustica na entressafra. Esta técnica também é eficiente para dissolver todo o depósito devido às gotículas de açúcar arrastado.

\subsubsection{Depósitos internos ou incrustações}

Durante a operação de um múltiplo-efeito, substâncias orgânicas diferentes que a sacarose e sais que não foram retirados na etapa de clarificação podem depositar-se nas paredes internas dos tubos, incrustando-as. As incrustações atuam como um isolante térmico diminuindo, significativamente, o coeficiente total de transmissão de calor $(U)$. 


\subsubsection{Formação das incrustações}

A formação de incrustações nos evaporadores deve-se, principalmente, a uma crescente redução de água do caldo em concentração, redução esta que permite aos não-açúcares atingirem, nos últimos efeitos, a condição de supersaturação e precipitarem. Entretanto, somado ao efeito da concentração, a temperatura elevada pode provocar a precipitação de alguns sais, principalmente nos primeiros vasos do múltiplo-efeito.

A formação de incrustações, de modo geral, são influenciadas pelas seguintes condições:

a) a composição do caldo que depende, principalmente, de:

- variedade da cana,

- tipo de solo cultivado,

- sistema de colheita da cana,

- estado de limpeza da cana,

- sistema de lavagem da cana,

- grau de extração das moendas.

b) peneiramento do caldo,

c) qualidade da cal, do enxofre e dos aditivos de clarificação,

d) processo de clarificação,

e) nível de caldo nas calandras dos evaporadores,

f) velocidade de circulação de caldo nos diversos vasos,

g) condição de vácuo nos evaporadores,

h) operação do múltiplo efeito,

i) polimento interno dos tubos.

Da relação anterior, os fatores a, b, c e d são decisivos para a obtenção de um caldo clarificado de boas características industriais. Um caldo clarificado ideal seria aquele que fosse composto apenas de sacarose e água. Na prática, pelos processos atuais de purificação, o caldo clarificado mostra uma composição apenas ligeiramente diferente do caldo que Ihe deu origem, enriquecido pelo íon cálcio, que é um dos elementos de maior presença nas incrustações. 
Os fatores relacionados nos itens e, $f, g$, h e i são também importantes na formação das incrustações. Desses fatores, tem-se atribuído ao nível de caldo na calandra considerável influencia na formação das incrustações, já que para um nível baixo de caldo nos tubos, tem-se uma maior velocidade de circulação, uma maior transmissão de calor e, conseqüentemente, uma menor taxa de incrustação.

O efeito de material suspenso, (bagacilho, fuligem, palha, etc.) no caldo clarificado tem pouca influência na formação das incrustações. Depositam-se sempre nos primeiros efeitos, razão pela qual as incrustações nesses vasos são mais macias.

Segundo Honig ${ }^{40}$, o comportamento de alguns componentes das incrustações em função da concentração e de temperatura é o seguinte:

a) sulfato, oxalato e aconitato de cálcio: aparecem nas incrustações dos últimos vasos pelo efeito da maior concentração, embora o sulfato possa ocorrer também nos primeiros vasos;

b) fosfato de cálcio, magnésio e ferro : precipitam-se nos primeiros vasos devido a maior temperatura e, nos últimos, devido às concentrações maiores;

c) gomas, pectinas, matérias protéicas e lipídeos: aparecem como incrustação nos primeiros vasos, onde são coagulados e precipitados devido às altas temperaturas;

d) silica $\left(\mathrm{SiO}_{2}\right)$ : sendo pouco solúvel a altas temperaturas, pode aparecer em pequena quantidade nas incrustações dos primeiros vasos. Entretanto, como também é menos solúvel nas soluções mais concentradas, a sílica aparece em maior porcentagem nas incrustações dos últimos vasos; e,

e) ferro: pode aparecer nos primeiros vasos, na forma de óxidos e de fosfatos. Nos últimos vasos, a sua presença tem sido constatada na forma de silicatos.

Independente de todos os fatores citados anteriormente, a formação das incrustações depende do polimento interno dos tubos, ou seja, quanto maior o polimento menor a formação de incrustação. Isto acontece porque em uma superfície polida os cristais em fase de formação não encontram porosidades e irregularidades superficiais para se aderirem. 
Isto explica porque tubos em aços inoxidáveis retém apenas 50\%, aproximadamente, das incrustações presentes em tubos de aço-carbono, quando forem mantidas idênticas as demais condições de evaporação.

\subsubsection{Limpeza das incrustações}

De modo geral, as incrustações dos primeiros efeitos de evaporação, sendo mais ricas em matérias orgânicas, são mais escuras e macias, enquanto que as dos últimos vasos, sendo mais ricas em material de natureza inorgânica, são mais claras e compactas, apresentando-se, por isso, mais duras e refratárias.

Os métodos empregados na limpeza podem ser de natureza mecânica ou química, podendo ser aplicados em conjunto ou isoladamente.

\subsubsection{Limpeza Mecânica}

O processo mecânico de remoção das incrustações é ainda muito usado pelas usinas de açúcar no Brasil. Ele utiliza raspadores, que podem ser de dois modelos: tipo "rasquete" e tipo "chicote flexível" ou "vibratório".

O tipo rasquete, de uso menos freqüente, consta de um varão metálico em cuja ponta é acoplado um elemento de aço, de construção especial, que age com certa pressão quando é passado pelo tubo. Essa peça se gasta com facilidade, sendo necessário trocá-la com frequência. Ela deve ajustar-se muito bem ao tubo. De modo geral ela entra com mais facilidade no tubo do que quando sai. Em substituição a esta peça pode ser usada uma escova de aço.

O tipo vibratório é composto por um motor elétrico que proporciona um movimento muito rápido a um cabo flexível de vários metros de comprimento, em cuja extremidade é acoplado um raspador mecânico. Esse raspador é constituído por três conjuntos de "rosetas", sendo cada conjunto composto de rosetas paralelas e uma cônica (extremidade), as quais pelo movimento centrífugo adquirido pela vibração do cabo se projetam contra as paredes do tubo, limpando-as. A remoção 
das incrustações com o chicote flexível ou vibratório pode ser feita a seco ou combinada com água. A água serve para diluir e facilitar o arraste das partículas sólidas para fora do tubo.

As desvantagens da limpeza mecânica são as seguintes:

a) processo demorado e desagradável à mão de obra; e,

b) ocasiona maior desgaste dos tubos.

- A limpeza por hidrojateamento pode ser classificada como limpeza mecânica. Esta sistemática de limpeza tem ganhado adeptos no Brasil, independente dos riscos físicos aos operadores e ao elevado consumo de água tratada.

Nela são usadas bombas de alta pressão, mangueiras flexíveis e lanças. A pressão da água é de $700 \mathrm{~kg}$, suficiente para desagregar todos os tipos de incrustações.

\subsubsection{Limpeza Química}

Os produtos químicos mais empregados são a soda cáustica $(\mathrm{NaOH})$ e o ácido muriático ( $\mathrm{HCl}$ grau técnico).

As concentrações desses reagentes e o tempo de imersão dos tubos são muito variados, sendo dependentes da natureza e intensidade das incrustações. Segundo Hugot, E. ${ }^{41}$, a soda dissolve principalmente os oxalatos, os sulfatos e os silicatos. O ácido clorídrico $(\mathrm{HCl})$ dissolve os carbonatos, os sulfitos e os fosfatos.

A solução de soda é usada a 6-8\%. Admite-se o agente de limpeza nos diversos efeitos até a altura do espelho superior e abre-se o vapor para a solução ferver a pressão atmosférica. A duração do tratamento é de 4 a 8 horas, dependendo da natureza da incrustação. A solução de soda é descarregada e estocada para uso futuro, após a correção da concentração.

A limpeza com ácido muriático tem sido evitada, pois desgasta os tubos e os gases clorídricos corroem todo o evaporador. 
2.7.4.3 Associação das limpezas mecânica e química

No caso de incrustações muito intensas ou muito resistentes, recomenda-se usar inicialmente uma limpeza mecânica, para em seguida fazer o tratamento químico com a solução de soda. Esta combinação é particularmente interessante no final da safra, pois se dispõe de bastante tempo para os dois tratamentos.

Após o término do tratamento a solução é descarregada para um depósito para novas aplicações ou descartada. Em seguida, lavam-se os tubos com água fria para acelerar o resfriamento das caixas.

Em função do critério da usina, uma nova fervura, agora com ácido muriático a 0,5 a $3 \%$ pode ser feita, demorando-se neste tratamento de duas a três horas.

Segundo observações de autores que se dedicaram ao assunto, ${ }^{38,41}$ o tratamento com soda nos últimos vasos nem sempre é suficiente para eliminar completamente as incrustações. A razão dessa pouca eficiência está no fato de que essas incrustações são mais duras e cristalinas e o teor de matéria orgânica é mais baixo.

Quando a solução de soda é reutilizada, deve-se adicionar $\mathrm{NaOH}$ até repor a concentração inicial. Quando essa solução apresenta-se muito impura, o que indica a presença de muita sílica, carbonatos, lipídios, etc., responsáveis por excessiva formação de espuma, recomenda-se descartá-la de forma ambientalmente correta e preparar uma nova solução, para atender a uma outra série de limpezas.

No Brasil é comum dissolver a soda diretamente nas caixas, após estas terem recebido água até a altura do espelho superior. Procede-se, em seguida, a fervura por quatro a oito horas.

O ácido muriático, independente dos inconvenientes já citados, segundo alguns observadores tem uma ação mais efetiva na limpeza dos evaporadores que a soda $^{42,44}$. Ele dissolve sulfitos, sulfatos, carbonatos, fosfatos, etc.

Alguns fabricantes de desincrustantes, visando atenuar ou impedir a ação corrosiva do $\mathrm{HCl}$, preparam soluções com inibidores, o que atenua bastante a ação corrosiva deste produto.

Além do $\mathrm{NaOH}$ e do $\mathrm{HCl}$, podem ser usados na limpeza das incrustações dos evaporadores o ácido sulfâmico, o etilenodiaminotetracetato de sódio (EDTA), o fluoreto de sódio, entre outros. 


\subsection{PRODUÇÃO DE TUBOS PARA EVAPORADORES}

A moderna indústria de tubos fabrica-os em aço-carbono e aços inoxidáveis para as mais diferentes aplicações e atendendo às especificações das normas internacionais ASTM, DIN, API e NBR. Em função dos seus usos, os tubos podem ser agrupados em:

- Para troca térmica (caldeiras, evaporadores, trocadores de calor, condensadores, etc);

- Para condução (condução de água, gás, vapor, óleo, ar comprimido e fluídos não corrosivos);

- Tubos mecânicos (para fins industriais, onde se requer precisão, como indústria automotiva, de motocicleta, de bicicleta, móveis, eletrodomésticos, etc);

- Tubos petrolíferos (condução de fluídos em plataformas marítimas para exploração de petróleo e gás); e,

- Tubos estruturais (construção civil, máquinas agrícolas, serralherias, etc).

Para troca térmica, é usado aço carbono com especificação SAE 1.008/12. Os aços inoxidáveis usados com este mesmo fim são os 304, 444, 439, 304 L, 316 e 316 L. Neste trabalho serão considerados apenas os três primeiros.

A Figura 13 mostra um fluxograma simplificado de uma fábrica de tubos. 


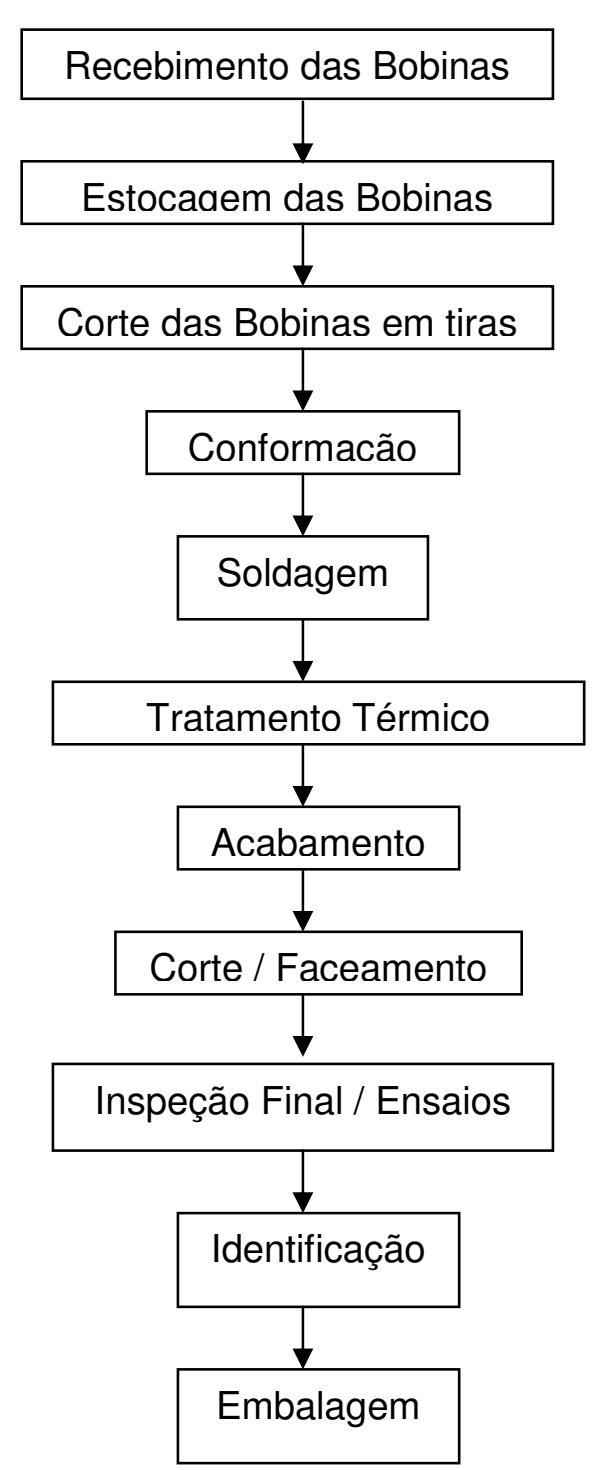

Figura 13 - Fluxograma de fabricação de tubos

Fonte: Catálogos sobre Fabricação e Produtos da PERSICO PIZZAMIGLIO S. A. ${ }^{45}$

Em uma descrição sucinta destas etapas tem-se:

- Recebimento das bobinas: A matéria-prima utilizada na fabricação dos tubos de aço-carbono e dos aços inoxidáveis é procedente das usinas siderúrgicas brasileiras sob forma de laminados planos em bobinas. As bobinas podem apresentar diferentes larguras e massas, em função das características dimensionais das lâminas e aplicações dos tubos. Excepcionalmente as lâminas podem passar por um processo de laminação de redução, de forma a atender a espessuras especiais.

- Estocagem das bobinas: As bobinas são estocadas por tipo de aço, aplicações e fornecedores, em galpão coberto. 
- Corte das Bobinas em Tiras: As bobinas são cortadas em tiras, em tesoura rotativa. A largura das tiras é aproximadamente igual ao diâmetro externo do tubo multiplicado por $\pi(3,1416)$. Esta aproximação depende da espessura da lâmina, do diâmetro do tubo, da conformação e da soldagem.

- Conformação: As tiras são conformadas mecanicamente em um sistema de roletes que dá origem ao "tubo" desejado.

- Soldagem: Os tubos em aços austeníticos e aços carbono são soldados pelo processo conhecido como Tungsten Inert Gás (TIG), sem adição de metal. Para os aços ferríticos, em função das suas características metalúrgicas, é utilizada a técnica de soldagem conhecida como Eletric Resistence Welding (ERW). O aço carbono também pode ser soldado via ERW. Para ambos processos de soldagem, o "cordão" de solda pode ser removido ou não. A Norma ASTM A 249 que é a mais utilizada, exige a remoção, enquanto que a ASTM A 269, não.

- Tratamento Térmico: A soldagem dos aços provoca a sensitização na região do cordão de solda. Este efeito é suprimido pelo aquecimento do tubo a $1040^{\circ} \mathrm{C}$ para os aços austeníticos, a $800^{\circ} \mathrm{C}$ para os aços ferríticos e os tubos em aço carbono a $900^{\circ} \mathrm{C}$, seguido por resfriamento brusco em água.

- Acabamento: Nesta etapa do processo, o tubo passa por roletes com o objetivo de endireitá-lo e eliminar possíveis ovalizações, calibrando-o a forma circular e reta. Nesta etapa também são eliminadas possíveis rebarbas e carepas. Os tubos em aços inoxidáveis podem também ser decapados em solução de ácido nítrico, de forma a melhorar a sua apresentação. Se solicitado, os tubos podem ser polidos.

- Corte / Faceamento: Nesta etapa o tubo é cortado no comprimento desejado e as suas extremidades faceadas, de forma a eliminar resíduos ainda presentes do corte, tornando-as seguras ao manuseio.

- Inspeção Final: Os tubos são amostrados e submetidos a testes não destrutivos (teste hidrostrático e teste eletromagnético) e a testes destrutivos (ensaio de tração, de achatamento do semi-tubo, de dobramento reverso, de flangeamento e de dureza).

- Identificação: Em todos os tubos é feita marcação, indicando tipo de aço, diâmetro externo, comprimento e norma que atende. 
- Embalagem: Os tubos podem ser embalados em pacotes amarrados com cinta em aço ou em caixas de madeira. Acompanha etiqueta com as características e destino da embalagem.

Os tubos em aço carbono para trocadores de calor e evaporadores são fabricados de forma a atender as Normas ASTM A 178 ou DIN 2458/1626, principalmente. Os tubos em aços inoxidáveis para estas mesmas aplicações devem atender às Normas ASTM A 249 ou A 269 (informações pessoais) ${ }^{1}$.

\footnotetext{
${ }^{1}$ Informações pessoais da Gerência de Produtos de um fabricante de tubos na Grande São Paulo
} 


\subsection{EVAPORADORES PARA USINAS DE AÇÚCAR CONSTRUÍDOS COM TUBOS EM AÇO-CARBONO E AÇOS INOXIDÁVEIS}

Até o final do século XIX a evaporação do caldo de cana era feita em tachos abertos e com fogo direto. Posteriormente, estes tachos passaram a trabalhar fechados, aquecidos com vapor e, em alguns casos, com pequeno vácuo.

O grande salto tecnológico na produção de açúcar se deu por volta de 1830, na Louisiana, EUA, por Norbert Rillieux. Ele, preocupado com o grande consumo de vapor, pensou: "já que se aquece o caldo com vapor, por que não utilizar o vapor fornecido pelo próprio caldo em aquecimento, para aquecer outra parte do caldo ou para terminar a evaporação iniciada com o vapor proveniente da caldeira?" A idéia de Rillieux era muito boa, porém surgiu uma dificuldade. Por exemplo, com vapor a $110^{\circ} \mathrm{C}$ é possível evaporar o caldo a pressão atmosférica. $\mathrm{O}$ vapor gerado neste processo, a $100^{\circ} \mathrm{C}$, entretanto, não consegue ferver o caldo a esta mesma temperatura, pois, termodinamicamente, é necessário uma diferença de temperatura entre o fluído aquecedor e o caldo a ser aquecido, ou usar vácuo. Esta foi à opção utilizada por Rillieux. Como a água ferve a $88^{\circ} \mathrm{C}$ com um vácuo de $25 \mathrm{~cm}$ de $\mathrm{Hg}$, a $80^{\circ} \mathrm{C}$ com um vácuo de $40 \mathrm{~cm}$, a $72^{\circ} \mathrm{C}$ com vácuo de $50 \mathrm{~cm}$, etc, é possível criar uma diferença de temperatura entre os fluídos e, desta forma, utilizar o vapor fornecido pelo primeiro efeito, para aquecer o caldo em um segundo efeito e, assim, sucessivamente. Acabava de nascer o evaporador múltiplo efeito.

$\mathrm{Na}$ fabricação de açúcar são utilizados vários tipos de evaporadores de múltiplos efeitos. No Brasil, em geral são usados evaporadores modelo clássico, com três a cinco efeitos conectados em série, com tubos verticais, por onde o caldo percorre-os no sentido ascendente (filme ascendente). Os tubos são em geral em aço-carbono e tem sido observada uma tendência de repô-los por tubos de aço inoxidável. Em algumas usinas ainda são encontrados tubos de cobre e, menos freqüentemente, de latão.

Hoje, com as exigências do mundo moderno, algumas características são recomendadas para os tubos a serem usados em aquecedores, evaporadores e cozedores de caldo de cana: ${ }^{46,47,48,49}$ 
- Resistência à corrosão;

- Coeficiente de expansão térmica similar ao do corpo do evaporador;

- Superfície interna dos tubos com alto polimento;

- Boa condutividade térmica;

- Características higiênico-sanitárias adequadas a um alimento;

- Relação benefício/custo altamente satisfatória;

- Ambientalmente sustentável; e,

- Seguro do ponto de vista alimentar.

Estas características podem ser mais ou menos atendidas pelos materiais:

- aços inoxidáveis;

- aço carbono; e,

- cobre.

\subsubsection{Projeto de um sistema de evaporação}

Para o sistema de evaporação objeto deste estudo, foi concebido um evaporador com um pré-evaporador e mais quatro efeitos. Este modelo vem a constituir um evaporador de uma usina de médio porte, muito comum em todo o Brasil. Para a confecção dos tubos deste sistema de evaporação foram considerados o aço-carbono (SAE 1.008/12) e três tipos de aços inoxidáveis, a saber: ${ }^{47,48,49,50}$

- 304 - É o aço inoxidável mais usado nas indústrias de alimentos e bebidas em todo o mundo, e com o qual se tem a maior experiência de uso em evaporadores para usinas de açúcar. Cabe salientar a Usina Pumaty S. A., localizada no município de Joaquim Nabuco, em Pernambuco, que o utiliza desde a safra de 1974;

- 444 - É um aço inoxidável desenvolvido mais recentemente, que apresenta resistência às corrosões químicas, por pites, frestas e sob tensão, bem como soldabilidade muito boas, que está sendo utilizado nas usinas de açúcar com resultados excelentes; 
- 439 - É um aço inoxidável de baixo custo, com boa soldabilidade e com uma resistência aos diferentes tipos de corrosão inferior aos aços 444 e 304. Este aço é pouco usado no Brasil, mas apresenta um grande potencial para uso em evaporadores para usinas de açúcar, principalmente porque o caldo de cana clarificado e com a acidez corrigida ( $\mathrm{pH}$ próximo a neutralidade) é pouco agressivo quimicamente. Este aço tem sido utilizado em usinas de açúcar na África do Sul há mais de uma década, com resultados muito promissores. ${ }^{47,48,49}$ A composição química destes materiais é apresentada na Tabela 10:44,51,52,53

Tabela 10 - Composição química aços usados na produção de tubos para evaporadores (\%)

\begin{tabular}{|c|c|c|c|c|c|c|c|c|c|c|}
\hline $\begin{array}{c}\text { Tipos de } \\
\text { Aços }\end{array}$ & $\mathbf{C}$ & $\mathbf{P}$ & $\mathbf{S}$ & $\mathbf{S i}$ & $\mathbf{M n}$ & $\mathbf{M o}$ & $\mathbf{C r}$ & $\mathbf{N i}$ & Outros & $\mathbf{N}$ \\
\hline Aço-C & 0,20 & 0,025 & 0,025 & 1,00 & 1,00 & - & - & - & - & - \\
\hline 304 & 0,08 & 0,045 & 0,030 & 0,75 & 2,00 & - & $18,0-20,0$ & $8,0-10,5$ & - & 0,10 \\
\hline 444 & 0,025 & 0,040 & 0,030 & 1,00 & 1,00 & $1,75-2,50$ & $17,5-19,5$ & 1,00 & $\mathrm{Ti}+\mathrm{Nb} \leq 0,8$ & 0,035 \\
\hline 439 & 0,070 & 0,040 & 0,030 & 1,00 & 1,00 & - & $17,0-19,0$ & 0,50 & $\mathrm{Ti}+\mathrm{Nb} \leq 0,75$ & 0,030 \\
\hline
\end{tabular}

Nota: Valores máximos, salvo onde faixa ou mínimo for indicado. 


\section{REALIZAÇÃO DOS ESTUDOS DE ACV DE EVAPORADORES PARA USINAS DE AÇÚCAR}

Neste capítulo são apresentados os estudos de Análise de Ciclo de Vida de evaporadores para usinas de açúcar, construídos com tubos em aço carbono e com os aços inoxidáveis 304, 444 e 439.

$\mathrm{Na}$ elaboração deste estudo foram utilizados os procedimentos estabelecidos pelas Normas ABNT NBR ISO $14040^{21}$, ABNT NBR ISO 14041 22 , ABNT NBR ISO $14042^{23}$ e ABNT NBR ISO $14043^{24}$, a seguir detalhados:

\subsection{DEFINIÇÃO DE OBJETIVO E ESCOPO}

De forma a bem caracterizar este estudo, deu-se início ao mesmo pelas definições do objetivo para o qual foi desenvolvido e do escopo de aplicação da ACV, para cada um dos materiais em avaliação.

\subsubsection{Objetivo do estudo}

O objetivo deste estudo de ACV consiste na avaliação do desempenho ambiental de um sistema de evaporação com cinco efeitos, para usinas de açúcar, cujos tubos são fabricados com aço carbono e, comparativamente, com os aços inoxidáveis 304, 444 e 439, desde a fabricação das chapas de aço, fabricação dos tubos, transporte, instalação, uso e substituição, por um período de trinta anos.

Justificaram este estudo os seguintes pontos:

- a pequena durabilidade dos tubos em aço carbono, o que obriga os usineiros a trocá-los parcialmente e partir do segundo ano de uso;

- a avaliação ambiental ainda não fazer parte do processo de decisão do empresário do setor de açúcar quanto a novos investimentos ou remodelamento dos evaporadores; 
- o setor fabricante de aço inoxidável e seus produtos ainda não ter plena consciência dos benefícios ambientais da substituição do aço carbono pelos diferentes tipos de aços inoxidáveis disponíveis; e,

- não existir estudos comparativos de ACV de equipamentos para usinas de açúcar construídos com diferentes tipos de aços. Este trabalho é inédito.

O público alvo deste trabalho são os empresários, profissionais, pesquisadores e acadêmicos do setor açucareiro e os empresários do setor de aço inoxidável.

\subsubsection{Escopo do estudo}

$\mathrm{Na}$ definição do escopo deste trabalho foram formuladas as premissas que estabeleceram as dimensões desta ACV, ou seja:

- a extensão - onde iniciar e parar o estudo;

- a largura - subsistemas que serão envolvidos; e,

- a profundidade - nível de detalhamento do estudo, tendo em vista o alcanse do objetivo e o seu público alvo.

Para tanto, foram considerados os seguintes elementos:

3.1.2.1 Função do sistema de produto

Para este estudo de ACV, a função do sistema em análise é evaporar parte da água presente no caldo de cana clarificado. 
3.1.2.2 Unidade funcional e fluxo de referência

Como unidade funcional capaz de atender à função do sistema de produto, foi escolhida a massa de água a ser evaporada pelo sistema de evaporação em estudo, igual a $20.10^{6} \mathrm{t}$.

Estabelecida a unidade funcional, foram calculados os fluxos de referência, ou seja, as quantidades mássicas dos diferentes tipos de tubos utilizados nos evaporadores, de forma que eles durem um período de trinta anos. O detalhamento dos cálculos utilizados será apresentado no próximo item 3.1.2.3, onde serão analisados os sistemas de produto que compõem este estudo.

\subsubsection{Sistemas de produto}

As usinas de açúcar no Brasil usam equipamentos fabricados na sua grande maioria em aço carbono. A pouca durabilidade deste material acarreta uma série de dificuldades ao longo da safra de cana, em função de paradas não previstas para manutenções ou troca de equipamentos. Na entressafra, a usina transforma-se em um canteiro de obras, com um grande número de serralheiros, soldadores e ajudantes, consertando ou substituindo equipamentos em aço carbono.

O sistema de evaporação de uma usina, também conhecido como evaporador, é uma das unidades de processo de maior importância quanto à qualidade do açúcar produzido, custo e rendimento da usina.

A durabilidade dos tubos em aço carbono utilizados nos evaporadores é relativamente pequena. Em geral estes tubos começam a serem substituídos devido à corrosão a partir do segundo ano de uso. Para alcançar o objetivo deste trabalho foi adotado como vida útil "média" destes tubos, seis anos. Este valor considerou as características técnicas de diferentes usinas e o desgaste mais acelerado dos tubos dos últimos efeitos e foi resultado de intensas discussões com as equipes técnicas de seis usinas de médio a grande porte visitadas no período de 2004 a 2006; bem como os inúmeros contatos com Professores e Pesquisadores do setor de açúcar. 
Para os tubos construídos com os aços inoxidáveis em avaliação, foi adotada uma vida útil média de 30 anos. Este valor foi utilizado tendo em vista a experiência da Usina Pumaty S.A., em Pernambuco, que pioneiramente utiliza tubos em aço 304 há 33 safras no seu sistema de evaporação. Estes tubos apresentam-se íntegros e com pequeno desgaste aparente apenas na sua superfície interna, tendo em vista a limpeza mecânica usada nos mesmos. A mesma durabilidade foi adotada para os tubos fabricados com os aços 444 e 439.

Subentende-se, portanto, que os tubos de aço carbono serão substituídos, em média, a cada seis anos, o que representa que em trinta anos os feixes de tubos dos diferentes efeitos serão trocados, em média, cinco vezes.

Como uma pequena fração dos tubos em aço inoxidável poderão vir a serem substituídos devido às falhas no mandrilamento, admitiu-se uma troca de $1 \%$ destes tubos a cada seis anos.

Para o cálculo da superfície de troca térmica de um sistema de evaporação capaz de atender à unidade funcional estabelecida para este estudo de ACV, foram adotadas as seguintes considerações:

- Taxa de evaporação de um quíntuplo efeito igual a $30 \mathrm{~kg} / \mathrm{h} / \mathrm{m}^{2}$;

Esta taxa de evaporação foi extraída do Quadro 33.18 de Hugot, E. - Manual da Engenharia Açucareira, $(1977)^{54}$, considerado livro texto sobre o assunto em todo o mundo.

- Período anual efetivo das safras de açúcar igual a 210 dias;

Em média, uma safra de açúcar estende-se por 250 dias, o período efetivo é calculado pela divisão do número total de horas trabalhadas por 24(horas/dia).

- Período de tempo do estudo igual à trinta anos.

Com estes dados, foi calculada a superfície de troca térmica:

Taxa de evaporação $=\quad$ Massa de água evaporada

Tempo de evaporação x Superfície de troca térmica

Onde: Taxa de evaporação $=30\left[\mathrm{~kg} / \mathrm{h} \mathrm{x} \mathrm{m}^{2}\right]$

Massa de água evaporada $=20 \times 10^{9}[\mathrm{~kg}]$

Tempo de evaporação $=30$ [anos] $\times 210$ [dias/ano] $\times 24$ [h/dia] $=151.200$ horas 
Lançando estes dados na equação acima, obteve-se o valor da Superfície de troca térmica.

SUPERFÍCIE DE TROCA TÉRMICA $=20 \times 10^{9} / 151200 \times 30=4.400 \mathrm{~m}^{2}$

Como superfície de troca térmica estende-se a superfície interna dos tubos. ${ }^{38,39,40,54,55}$

Para o sistema de evaporação com esta superfície de troca térmica adotou-se um pré-evaporador com $2.000 \mathrm{~m}^{2}$ e quatro efeitos com $600 \mathrm{~m}^{2}$ cada um.

Essa escolha deveu-se ao fato que sistemas de evaporação deste porte e com esta distribuição de superfícies de troca entre os efeitos é comum em usinas de pequena à média capacidade de esmagamento de cana, as quais são maioria das usinas em operação no Brasil. ${ }^{39}$

Como os tubos em aço carbono e nos diferentes tipos de aços inoxidáveis são fabricados com diferentes espessuras, este estudo de ACV levantou dados relativos a seis sistemas de produtos, a saber:

- Sistema de Produto Tubos em Aço-Carbono com 2,65 mm;

- Sistema de Produto Tubos em Aço Inoxidável 304 com 1,20 mm;

- Sistema de Produto Tubos em Aço Inoxidável 304 com 1,50 mm;

- Sistema de Produto Tubos em Aço Inoxidável 444 com 1,20 mm;

- Sistema de Produto Tubos em Aço Inoxidável 444 com 1,50 mm;

- Sistema de Produto Tubos em Aço Inoxidável 439 com 1,50 mm.

Para o cálculo das quantidades de tubos do sistema de evaporação, foram usados tubos com $38,10 \mathrm{~mm}$ de diâmetro externo. No pré-evaporador foram usados tubos com $4.000 \mathrm{~mm}$ de comprimento total e nos demais efeitos tubos com 3.000 $\mathrm{mm}$. Foram considerados também espelhos com $31,75 \mathrm{~mm}$ de espessura e uma altura de mandrilamento igual a $10 \mathrm{~mm}$. Desta forma, os tubos passaram a ter um comprimento útil para troca térmica igual a 3.916,5 e 2.916,5 mm, respectivamente. Estes parâmetros são comuns para sistemas de evaporação deste tamanho.

A Tabela 11 apresenta as principais características dos tubos usados nos diferentes sistemas de produto, as quais foram utilizadas nos cálculos das quantidades de tubos por efeito e as massas dos mesmos. 
O cálculo do número de tubos por efeito bem como a massa destes tubos será exemplificada para o primeiro efeito do sistema de produtos Aço-C:

- Superfície interna por tubo $=0,1030 \mathrm{~m}^{2} / \mathrm{m} \times 3,9165 \mathrm{~m}=0,4034 \mathrm{~m}^{2} / \mathrm{tubo}$

- Número de tubos do $1^{\circ}$ efeito $=2.000 \mathrm{~m}^{2} / 0,4034 \mathrm{~m}^{2} /$ tubo $=4.958$ tubos

- Massa dos tubos do $1^{\circ}$ efeito $=4.958$ tubos $\times 4 \mathrm{~m} / \mathrm{tubo} \times 2,32 \mathrm{~kg} / \mathrm{m}=46.010 \mathrm{~kg}=$ $46,0 \mathrm{t}$

Tabela 11 - Parâmetros básicos relacionados aos sistemas de produto

\begin{tabular}{|c|c|c|c|c|c|c|c|}
\hline \multirow{3}{*}{\multicolumn{2}{|c|}{\begin{tabular}{|r|} 
PARÂMETROS \\
Espessura da Parede $(\mathrm{mm})$ \\
\end{tabular}}} & \multicolumn{6}{|c|}{ SISTEMAS DE PRODUTO } \\
\hline & & \multirow{2}{*}{$\frac{\text { Aço-C }}{2,65}$} & \multicolumn{2}{|c|}{304} & \multicolumn{2}{|c|}{444} & \multirow{2}{*}{$\begin{array}{l}439 \\
1,50\end{array}$} \\
\hline & & & 1,20 & 1,50 & 1,20 & 1,50 & \\
\hline \multicolumn{2}{|c|}{$\begin{array}{l}\text { Superfície Interna para Troca Térmica } \\
\left(\mathrm{m}^{2} / \mathrm{m}\right)\end{array}$} & 0,1030 & 0,1122 & 0,1103 & 0,1122 & 0,1103 & 0,1103 \\
\hline \multicolumn{2}{|c|}{ Massa por Metro Linear $(\mathrm{kg} / \mathrm{m})$} & 2,32 & 1,11 & 1,37 & 1,09 & 1,35 & 1,32 \\
\hline \multicolumn{2}{|c|}{ Densidade $\left(\mathrm{g} / \mathrm{cm}^{3}\right)$} & 7,8 & \multicolumn{2}{|c|}{8,1} & \multicolumn{2}{|c|}{7,8} & 7,7 \\
\hline \multirow[t]{2}{*}{$1^{\circ}$ Efeito } & № Tubos & 4.958 & 4.551 & 4.630 & 4.551 & 4.630 & 4.630 \\
\hline & Massa do Efeito (t) & 46,0 & 20,2 & 25,4 & 19,8 & 24,8 & 24,5 \\
\hline \multirow{2}{*}{$\begin{array}{l}20-50 \\
\text { Efeitos }\end{array}$} & № Tubos & 7.989 & 7.334 & 7.461 & 7.334 & 7.461 & 7.461 \\
\hline & Massa dos 4 Efeitos (t) & 55,6 & 24,4 & 30,7 & 24,0 & 30,2 & 29,6 \\
\hline \multicolumn{2}{|c|}{ Número total de Tubos } & 12.947 & 11.885 & 12.091 & 11.885 & 12.091 & 12.091 \\
\hline \multicolumn{2}{|c|}{ Massa Total do Sistema (t) } & 101,6 & 44,6 & 56,1 & 43,8 & 55,0 & 54,1 \\
\hline \multicolumn{2}{|c|}{ Fluxo de Referência (t) } & 508,0 & 46,8 & 58,9 & 46,0 & 57,8 & 56,8 \\
\hline
\end{tabular}

Para o cálculo dos fluxos de referências para os seis sistemas de produto que compõem este estudo de ACV foram consideradas as durabilidades dos tubos e a troca dos tubos em aços inoxidáveis devido às falhas no mandrilamento. 
3.1.2.3.1 Sistema de produto tubos em aço carbono

O Sistema de produto tubos em aço carbono será o primeiro a ser detalhado, pois esta é a opção para sistemas de evaporação mais em uso até o momento. A Figura 14 apresenta um fluxograma representativo para este sistema de produto.

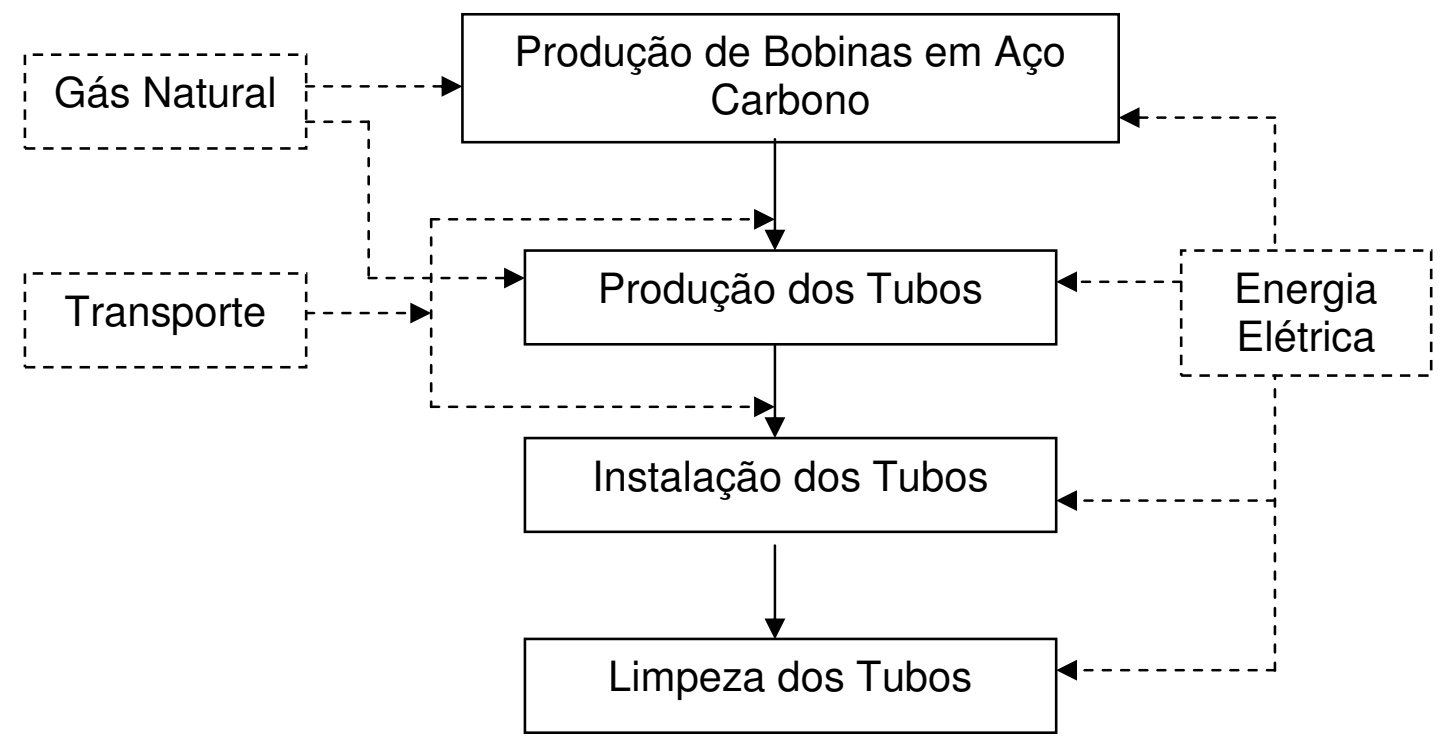

Figura 14 - Fluxograma do sistema de produto tubos em aço carbono

Constata-se que este sistema de produto conforme ele foi concebido, é constituído pelos seguintes subsistemas:

- produção de bobinas em aço carbono;

- produção dos tubos;

- instalação dos tubos;

- limpeza dos tubos;

- gás natural;

- energia elétrica;

- transporte.

Ao analisar-se a Figura 14, depara-se com subsistemas assinalados por linhas cheias, que se referem ao fluxo principal deste sistema de produto e os subsistemas gás natural, energia elétrica e transporte, mostrados em linhas tracejadas, que representam subsistemas auxiliares. 
$\mathrm{Na}$ prática outros subsistemas fazem parte deste sistema de produtos, dos quais podem ser citados:

- a movimentação das bobinas no depósito da usina siderúrgica;

- a movimentação dos tubos na usina de açúcar;

- a soldagem (fechamento) dos tubos furados ao longo da safra;

- a perda de eficiência térmica dos evaporadores durante o período de operação devido a formação de incrustações e o fechamento dos tubos;

- a estocagem e destinação final das sucatas dos tubos, etc.

Estes subsistemas não foram considerados devido a falta de daods consolidados.

O fluxograma representativo para tubos fabricados em aço carbono é iniciado pelo subsistema produção de bobinas em aço carbono. Considerou-se que este material foi produzido, lingotado, laminado e embobinado por uma usina integrada localizada a $250 \mathrm{~km}$ da grande São Paulo. Esta distância vem a ser a média ponderada entre as distâncias e as contribuições de fornecimento de bobinas das três usinas que atendem os fabricantes de tubos da grande São Paulo.

As bobinas foram transportadas até as fábricas de tubos instaladas na grande São Paulo via transporte rodoviário.

O subsistema produção dos tubos é formado pelas operações de recebimento, estocagem e corte das bobinas; conformação; soldagem; tratamento térmico; decapagem; acabamento, corte e faceamento; seguido pela inspeção final, identificação, embalagem e colocação na rampa de embarque.

Os tubos foram transportados até uma usina de açúcar de grande porte localizada na Região da Alta Mogiana, distante $430 \mathrm{~km}$ da grande São Paulo. Independente de terem sido visitadas várias usinas de açúcar para a realização deste trabalho, optou-se pelo uso das informações de uma única usina. Justificaram esta decisão os seguintes fatores:

- a dificuldade em se conseguir informações completas em algumas usinas;

- esta usina começou a usar um aço inox na safra de 2000. Como não existia na região uma experiência consolidada, começou testando o aço inoxidável 316 e, posteriormente, os aços 444 e 439. A partir daquela safra, ela vem substituindo paulatinamente os tubos em aço carbono, tendo agora optado pelo uso de tubos 
em aço 439 nos primeiro, segundo e terceiro efeitos, e 444 no quarto e quinto efeitos.

- a impossibilidade de se estabelecer valores "médios" com relação aos tempos para instalação, substituição e limpeza dos tubos dos evaporadores, bem como o uso das utilidades. Em suma, cada usina apresenta um comportamento distinto.

Em várias oportunidades foram usados dados reais e informações desta empresa que passará a ser apresentada como "usina parceira".

O subsistema instalação dos tubos englobou a instalação dos tubos propriamente dita, bem como a etapa de retirada dos mesmos para substituição. Esta etapa também foi considerada, pois consome energia elétrica.

O subsistema limpeza dos tubos foi relacionado à remoção das incrustações que se formaram nas paredes internas dos tubos durante a evaporação. Na limpeza dos tubos foram consumidos energia elétrica, água e, ou, produtos químicos, razão pela qual a sua inclusão neste estudo. Neste trabalho foi considerado o sistema de limpeza mecânica.

O subsistema gás natural foi considerado devido a sua participação na fabricação dos aços e dos tubos. Não foram englobadas as etapas relacionadas à sua geração (extração, produção, purificação e transporte).

O subsistema energia elétrica foi considerado por participar dos quatro subsistemas principais e baseou-se no consumo de energia elétrica nestes subsistemas.

Com relação ao subsistema transporte, foi considerado apenas o consumo de óleo diesel utilizado no transporte das bobinas e dos tubos.

\subsection{Sistemas de produto tubos em aços inoxidáveis}

Este item engloba, na realidade, cinco sistemas de produto para tubos fabricados com os aços inoxidáveis 304, 444 e 439, sendo que para os dois primeiros, foram usadas espessuras de parede iguais a 1,20 e 1,50 mm, respectivamente; e para o 439, 1,50 $\mathrm{mm}$ de espessura. 
A Figura 15 apresenta o fluxograma representativo para estes sistemas de produto.

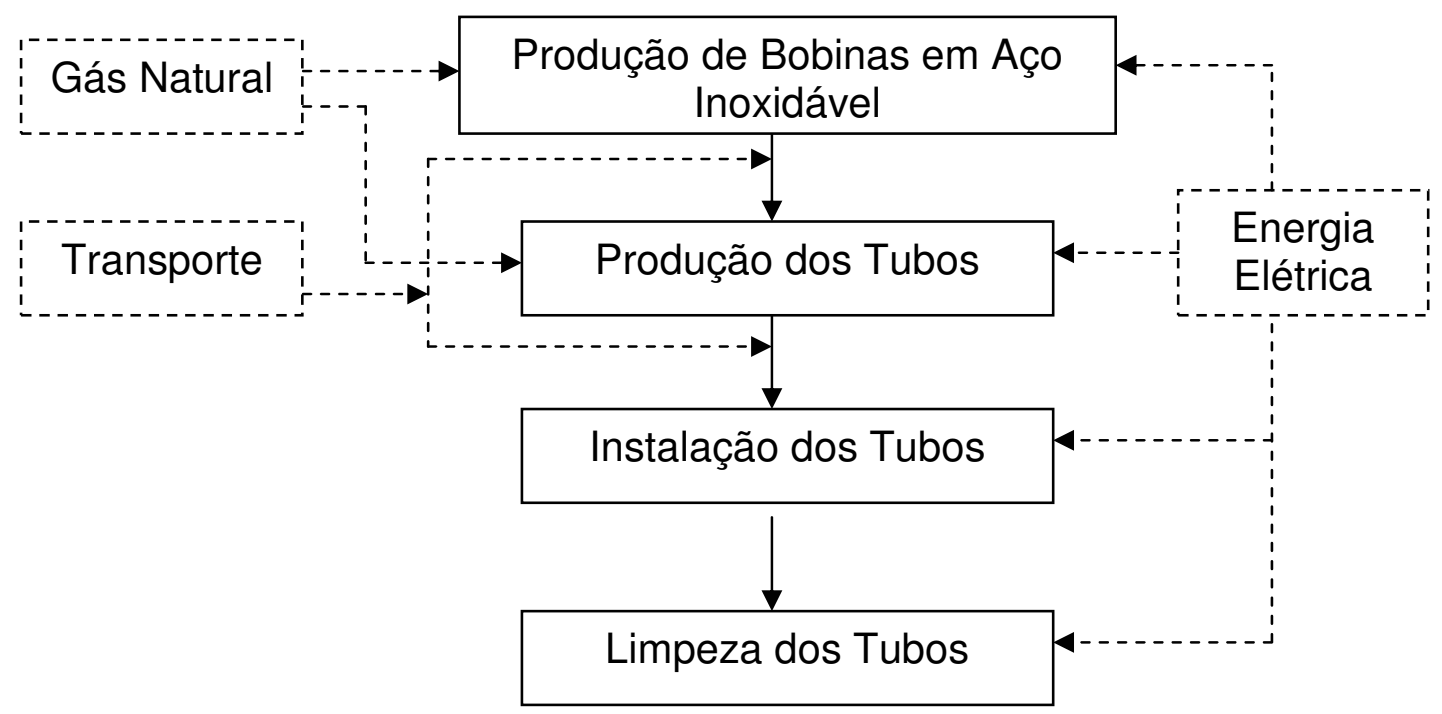

Figura 15 - Fluxograma representativo dos sistemas de produto para os tubos fabricados com aços inoxidáveis 304, 444 e 439

As Figuras 14 e 15 são semelhantes. Isto acontece porque os subsistemas principais e auxiliares envolvidos na produção dos tubos em aço carbono e nos aços inoxidáveis são semelhantes na sua estrutura. Eles diferem, entretanto, no consumo de matérias-primas e energia, nas suas emissões aéreas e líquidas bem como na produção de resíduos sólidos. Ou seja, diferem nas suas cargas ambientais.

Foi considerada a via forno elétrico a arco (FEA) para a produção dos aços inoxidáveis.

Foi considerada a produção das bobinas em uma usina integrada instalada na região ferrífera de Minas Gerais, distante 770 km de São Paulo.

\subsubsection{Fronteiras dos sistemas de produto}

As fronteiras do sistema de produto são as bases para a delimitação das dimensões do estudo de ACV. Do ponto de vista prático, a definição das fronteiras do sistema de produto em estudo indicará que subsistemas foram incluídos e 
aqueles que não farão parte do estudo de ACV. A seguir são apresentados os subsistemas que foram desconsiderados, bem como as razões que fundamentaram estas decisões.

Como mostrado no item 3.1.2.3.2, página 127, os seis sistemas de produto em avaliação apresentam estruturas semelhantes, o que justificou uma abordagem em conjunto das fronteiras adotadas para os subsistemas:

- No subsistema produção dos tubos foi excluído o subsistema laminação. Esta etapa acontece raramente, já que as lâminas para estes tipos de tubos são recebidas nas suas espessuras definitivas. Justificou-se esta decisão a sua baixa freqüência.

- No subsistema limpeza dos tubos foi considerada a limpeza mecânica, já que é o tipo de limpeza ainda mais utilizado para tubos em aço carbono.

- No subsistema energia elétrica foi utilizado apenas o valor de consumo, sem considerar as formas de geração, bem como aspectos relacionados à construção de usinas, operação e transporte de energia, por não fazerem parte do objetivo do estudo. O subsistema co-geração de energia elétrica nas usinas não foi considerado por estar em operação em um número reduzido de usinas.

- No subsistema transporte foram excluídos os subsistemas relacionados à produção dos veículos e a construção das estradas de rodagem. Justificou-se esta decisão por estes subsistemas não fazerem parte dos objetivos deste estudo.

Como fronteira temporal, os dados relativos à durabilidade dos tubos de aço carbono foram coletados entre 2004 e 2006, período em que o setor açucareiro cresceu e se desenvolveu tecnicamente. Ou seja, em anos anteriores, o nível técnico das usinas era menor, o que ocasionava, entre outras dificuldades, uma menor durabilidade dos tubos dos evaporadores.

A questão da durabilidade dos tubos de aço carbono merece atenção especial. No escopo deste trabalho adotou-se como durabilidade média para estes tubos uma vida útil de seis anos. Como citado anteriormente, não existem registros ou estudos sobre este valor. Ele foi obtido a partir de discussões com as áreas técnicas de usinas de médio à grande porte. Para usinas de pequeno porte, esta durabilidade poderá ser ainda menor.

Com relação às fronteiras dos sistemas, cabe ainda salientar que, independentemente dos dados terem sido coletados na sua maioria no Estado de 
São Paulo, as conclusões deste estudo poderão ser utilizadas em todo o território nacional, já que os processos tecnológicos para a produção dos aços, dos tubos e do açúcar são semelhantes.

\subsubsection{Procedimentos de alocação}

Nos subsistemas produção das bobinas de aço carbono e dos aços inoxidáveis as fronteiras dos mesmos foram ampliadas de forma a incluir as funções adicionais aos co-produtos, levando em consideração os requisitos do item 5.3.2, da ABNT NBR ISO 14041:2004 22,56,57

Para os demais subsistemas, devido a falta de dados representativos, foi considerado que eles não geraram co-produtos ou cargas ambientais para serem alocadas.

\subsubsection{Requisitos de qualidade dos dados}

De forma a atender os requisitos estabelecidos pelas Normas NBR ISO 14040:2001 ${ }^{21}$ e ABNT NBR ISO 14041:200422 o período de tempo e a área geográfica cobertos por este trabalho foram tratados nas fronteiras dos sistemas de produto em estudo.

Quanto às tecnologias envolvidas, os subsistemas de produção das bobinas de aço carbono e dos aços inoxidáveis são os que merecem maior atenção. Estes subsistemas são também os que ocasionam os maiores impactos ambientais e tem merecido inúmeros estudos de ACV em todo o mundo moderno. A elaboração de um ICV para a produção de bobinas de aço carbono no Brasil, por exemplo, exigiria um extenso levantamento de dados relativos às entradas (matérias-primas e fontes de energia de diferentes origens) e às saídas (produto final, co-produto(s) e emissões); bem como aos balanços de massa e energia ao longo das diferentes etapas de fabricação. Estes dados seriam coletados em diferentes setores de várias empresas e, além da dificuldade física do seu recolhimento, esbarrariam em patentes e, ou, 
dados confidenciais. Em função disto e de forma a não regionalizar ou explicitar uma única empresa em questões ambientais tão relevantes, foram adotados os dados publicados pelas instituições International Iron and Steel Institute - $\left.I S\right|^{56}$ e pelo International Stainless Steel Forum - ISSF ${ }^{57}$, que são hoje utilizados como valores "médios" mundiais.

\subsubsection{Análise crítica}

No presente estudo de ACV, objeto de uma tese de doutorado, foram utilizados os procedimentos estabelecidos pelas Normas NBR ISO 14040:2001 ${ }^{21}$, ABNT NBR ISO 14041:200122, ABNT NBR ISO 14042:2004 ${ }^{23}$ e ABNT NBR ISO 14043:2005 ${ }^{24}$. Entretanto, tendo em vista o caráter acadêmico desta fase do trabalho, optou-se pela não realização de uma análise crítica.

3.1.2.8 Tipo e formato de relatório

Este trabalho de ACV foi realizado de forma a atender aos preceitos acadêmicos exigidos para tal; bem como às Normas NBR ISO relativas aos trabalhos de ACV. Desta forma, como este documento satisfaz aos requisitos de fidelidade, clareza, completeza, precisão e exatidão exigidas pela Norma NBR ISO 14040:2001 ${ }^{21}$, o mesmo substituirá o relatório final previsto na referida Norma. 


\subsection{ANÁLISE DE INVENTÁRIO}

A análise de inventário do ciclo de vida - ICV é a segunda fase de uma ACV. Esta fase é subdividida em três conjuntos de procedimentos; a saber:

- Preparação para a coleta de dados;

- Coleta de dados;

- Tratamento dos dados.

Estes procedimentos são executados com o objetivo de quantificar as entradas e saídas de um dado sistema de produto, considerando as diferentes categorias de impacto, as fronteiras e relacionando estes dados à unidade funcional estabelecida no escopo da ACV.

\subsubsection{Preparação para coleta de dados}

Como apresentado no item anterior, os sistemas em estudo apresentam uma estrutura semelhante, composta por quatro subsistemas principais e três subsistemas auxiliares. Desta forma, a coleta de dados será feita por subsistema, para todos os sistemas de produto em estudo.

\subsubsection{Coleta de dados}

3.2.2.1 Subsistema produção de bobinas em aço carbono

O Apêndice A, apresenta o ICV para lâminas de aço carbono fabricadas via rota de alto forno, por $1000 \mathrm{~kg}$ de produto. Os dados apresentados nesta planilha foram extraídos do Appendix 7A, B: System Expansion vs. No Allocation, BF Route for HRC (Hot Rolled Coil) and HDG, que faz parte da publicação "World Steel Life 
Cycle Inventory", do International Iron and Steel Institute - IISI, Appendix 5 Application of the IISI LCI data to Recyclings Scenarios ${ }^{56}$, publicada em outubro de 2002. Os dados para a elaboração do referido trabalho foram coletados no período 1999 - 2000, em trinta e quatro usinas integradas, treze usinas equipadas com forno elétrico e três usinas que fazem a redução direta de minério de ferro. Vinte e oito destas usinas estão localizadas em países europeus, doze do extremo leste asiático e dez da América do Norte, África e Europa Oriental.

Estas possíveis diferenças precisam ser avaliadas e analisadas quanto a sua aceitação. Caso aceitas, devem ser informadas para que não prejudiquem as conclusões do trabalho e possíveis recomendações.

Nos ICVs elaborados por estas usinas foram considerados os aspectos ambientais relacionados desde a extração das matérias-primas, até a confecção dos produtos acabados (ciclo de vida).

Participaram também quatorze empresas transformadoras de aço carbono dos setores automotivos, de embalagem e construção civil. Neste estudo foram preparados ICV's relativos a quatorze produtos fabricados nestas empresas, dos quais um deles são bobinas utilizadas na manufatura de produtos diversos, tais como tubos para trocadores de calor, por exemplo. Os resultados deste estudo passaram por análise de sensibilidade e por um painel externo independente para análise crítica. Estes resultados têm sido utilizados em todo o mundo como resultados "médios" mundiais (global average), para avaliar a performance de produtos de aço no contexto do desenvolvimento sustentável, reciclagem e melhorias de processo.

O uso de dados coletados na literatura publicada, mesmo que cubra lacunas na informação, muitas vezes impossíveis de serem preenchidas em anos ou décadas, merece especial atenção, tendo em vista aos diferentes aspectos ambientais relacionados ao sistema de produto em avaliação. Os mais comuns são: matérias-primas renováveis ou não; matriz energética; tipo de transporte; uso, reuso e reciclagem.

$\mathrm{Na}$ elaboração deste inventário do ciclo de vida, algumas matérias-primas entram no processo como componentes de massa (carvão, coque, óleos, etc.) e constituem componentes de energia também, para o qual foram calculados em função do seu poder calorífero. 
Os indicadores de energia utilizados nos ICVs deste estudo, são os diferentes tipos de energia que participam dos processos e são subdivididos em: ${ }^{56}$

- Energia primária total: representa a soma de todas as fontes extraídas diretamente da natureza, tais como gás natural, petróleo, carvão, biomassa ou energia hidrelétrica. A energia primária total compreende outras formas de energia denominadas como renovável, não renovável, combustível e energia de estoque, que serão descritas em seguida.

- Energia não renovável: inclui todas as fontes minerais e fósseis, tais como gás natural, petróleo, carvão e energia nuclear.

- Energia renovável: inclui todas as outras fontes primárias de energia, tais como as hidrelétricas e biomassa.

- Energia combustível: cobre toda a energia gasta para que o processo aconteça, tais como para produzir calor, energia mecânica ou permitir que reações endotérmicas se realizem.

- Energia de "estoque": é a parte da energia primária que não é consumida ou disponibilizada como energia combustível para uso fora das fronteiras do sistema. $\mathrm{Na}$ fabricação de aço, corresponde ao valor calorífero dos produtos fabricados (aços e escória), bem como as perdas de combustível.

3.2.2.2 Subsistemas produção de bobinas dos aços inoxidáveis 304 2B, 444 e 439

O Apêndice B apresenta o ICV para os aços inoxidáveis 304 2B, 444 e 439, fabricados via forno elétrico a arco, por $1000 \mathrm{~kg}$ de produto. Para o aço inoxidável 304 2B foram utilizados os dados apresentados na Tabela "Inventory: Stainless_Steel_World_304_2B for 1000 kg Product", que faz parte do estudo LCI / LCA of stainless steel: ISSF HLE Project 2003/2004, elaborado pelo International Stainless Steel Forum - ISSF ${ }^{57}$. Este estudo elaborou ICVs para mais sete aços inoxidáveis, a saber:

- $304 \mathrm{BA}$;

- 304 WHR;

- $3162 \mathrm{~B}$; 
- $4092 \mathrm{~B}$

$-4302 \mathrm{~B}$;

- $430 \mathrm{BA}$;

- $22052 \mathrm{~B}$.

Obs.: BA, WHR e 2B referem-se aos tipos de polimento usados.

Os dados de ICV relativos aos aços inoxidáveis 444 e 439 foram calculados a partir dos valores apresentados na tabela Inventory: Stainless_Steel_World_430_2B for $1000 \mathrm{~kg}$ Product ${ }^{57}$, que faz parte do mesmo estudo citado anteriormente, com os acertos de composição necessários e, consequentemente, ajustes das entradas e saídas para alguns aspectos ambientais, tomando como base informações disponíveis na publicação KIRK OTHMER Encyclopedia of Chemical Technology. ${ }^{55,58,59,60,61,62,63,64}$

Estes cálculos são possíveis porque os aços inoxidáveis 430, 439 e 444 apresentam estrutura e composições químicas semelhantes, como apresentado na Tabela 12.

Nas usinas, os aços inoxidáveis 439 e 444 são, muitas vezes, fabricados a partir do aço $430 .^{65}$

Esta aproximação também é aceita pela ABNT NBR ISO 14041:2004²2.

É importante salientar que na elaboração dos ICVs dos aços inoxidáveis 304 $2 \mathrm{~B}$ e 430 foram considerados todos os aspectos ambientais relacionados às sucatas de aço carbono utilizadas na fabricação dos mesmos.

Tabela 12 - Composição química dos aços inoxidáveis 430, 444 e 439

\begin{tabular}{|c|c|c|c|c|c|c|c|c|c|c|c|}
\hline \multirow{2}{*}{$\begin{array}{c}\text { Aço } \\
\text { Inoxidável }\end{array}$} & \multicolumn{10}{|c|}{ Parâmetros (\%) } \\
\cline { 2 - 37 } & $\mathrm{C}$ & $\mathrm{P}$ & $\mathrm{S}$ & $\mathrm{Si}$ & $\mathrm{Mn}$ & $\mathrm{Cr}$ & $\mathrm{Ni}$ & $\mathrm{Mo}$ & $\mathrm{Ti}+\mathrm{Nb}$ & $\mathrm{N}$ & $\mathrm{Fe}$ \\
\hline 430 & 0,12 & 0,04 & 0,03 & 0,03 & 1,00 & 17,0 & - & - & - & - & 81,8 \\
\hline 444 & 0,025 & 0,04 & 0,03 & 0,03 & 1,00 & 18,0 & 1,0 & 2,0 & 0,80 & 0,035 & 77,5 \\
\hline 439 & 0,03 & 0,04 & 0,03 & 0,03 & 1,00 & 18,5 & 0,5 & - & 0,75 & 0,03 & 78,6 \\
\hline
\end{tabular}

Observações:

1) Para Cr e Mo foram usados valores médios;

2) As porcentagens do elemento Fe foram calculadas por diferença;

3) Para os demais elementos foram considerados os valores máximos. 
O ISSF faz parte da estrutura do IISI. Este último trabalho do ISSF veio dar continuidade aos estudos inicialmente conduzidos pelo IISI para o aço carbono ${ }^{79}$. Ele foi realizado no período 2003/2004 e foram coletadas informações em doze usinas fabricantes de aços inoxidáveis via FEA instaladas em vários continentes. Os dados deste trabalho têm sido utilizados em todo o mundo para subsidiar estudos relativos a produção de aços inoxidáveis a partir de sucatas ${ }^{66}$ e melhorias de processo, em especial visando a redução da emissão de $\mathrm{CO}_{2}, \mathrm{SO}_{\mathrm{x}}, \mathrm{NO}_{\mathrm{x}}$ e consumo de energia. ${ }^{67}$

\subsection{Considerações}

$\mathrm{Na}$ elaboração dos ICVs dos aços inoxidáveis 444 e 439 apresentados no Apêndice $B$, os valores para alguns parâmetros foram calculados, tomando como base as seguintes considerações:

a) Composição química dos aços inoxidáveis 430, 444 e 439.

A Tabela 12 apresenta a composição química dos aços inoxidáveis 430, 444 e 439.

b) Composição química principal dos minérios utilizados.

A Tabela 13 apresenta as porcentagens de ferro $(\mathrm{Fe})$, carbono (C) e enxofre (S) nos minérios utilizados na fabricação dos aços inoxidáveis 444 e 439 .

Tabela 13 - Teores de Fe, C e S nos minérios usados na fabricação dos aços inoxidáveis 444 e 439

\begin{tabular}{|l|c|c|c|}
\hline \multirow{2}{*}{\multicolumn{1}{|c|}{ Minerais }} & \multicolumn{3}{c|}{ Parâmetros (\%) } \\
\cline { 2 - 4 } & $\mathrm{Fe}$ & $\mathrm{C}$ & $\mathrm{S}$ \\
\hline Hematita & 68 & - & - \\
\hline Carvão Mineral $^{*}$ & - & 69 & 0,50 \\
\hline
\end{tabular}

* Poder Calorífero Inferior do Carvão igual a $4.700 \mathrm{Kcal} / \mathrm{kg}$. 
c) Fornecimento dos metais cromo (Cr), níquel (Ni), molibdênio (Mo), titânio (Ti) e nióbio $(\mathrm{Nb})$.

Os teores dos elementos de liga $\mathrm{Cr}$, $\mathrm{Ni}$, Mo, $\mathrm{Ti}$ e $\mathrm{Nb}$ nas ferro-ligas utilizadas na fabricação dos inox 444 e 439 são apresentadas na Tabela 14.

Os aumentos dos teores de $\mathrm{Cr}$ nos inox 444 e 439 refletiram, nas mesmas proporções, nas emissões dos compostos deste elemento.

Tabela 14 - Teores dos elementos de liga nas ferro-ligas utilizadas na produção dos aços inoxidáveis 444 e 439

\begin{tabular}{|l|c|c|c|c|c|c|}
\hline \multirow{2}{*}{\multicolumn{1}{|c|}{ Ferro-liga }} & \multicolumn{6}{|c|}{ Parâmetros (\%) } \\
\cline { 2 - 7 } & $\mathrm{Cr}$ & $\mathrm{Ni}$ & $\mathrm{Mo}$ & $\mathrm{Ti}$ & $\mathrm{Nb}$ & $\mathrm{Fe}$ \\
\hline Cromo & 54,3 & - & - & - & - & 45,1 \\
\hline Níquel & - & 40,0 & - & - & - & 59,1 \\
\hline Molibdênio & - & - & 59,0 & - & - & 40,2 \\
\hline Titânio & - & - & - & 37,5 & - & 60,9 \\
\hline Nióbio & - & - & - & - & 66.2 & 33.7 \\
\hline
\end{tabular}

d) Correções nas quantidades de carvão e calcita utilizadas na fabricação dos aços inoxidáveis 444 e 439.

As quantidades de carvão e calcita utilizadas na fabricação dos aços inoxidáveis 444 e 439 foram recalculadas a partir dos dados de inventário do aço inox 430, em função das novas quantidades de minério de ferro necessárias para a produção destes aços. As novas quantidades de carvão mineral utilizadas refletiram nas emissões de dióxido de carbono, dióxido de enxofre e nos indicadores de energia, já que a queima completa de $1 \mathrm{~kg}$ de carvão libera 2,53E+03 g de $\mathrm{CO}_{2}$, $6,90 \mathrm{E}+00 \mathrm{~g}$ de $\mathrm{SO}_{2}$ e $4700 \mathrm{kcal}$ de energia não renovável (19,7 MJ).

\subsubsection{Subsistema produção dos tubos}


$\mathrm{Na}$ fabricação de tubos com 38,10 mm de diâmetro externo em aço carbono e nos aços inoxidáveis são usadas lâminas com 1250 e 1200 mm de largura, respectivamente.

Dados levantados em empresas deste setor industrial localizadas na grande São Paulo mostram que para a fabricação de $1000 \mathrm{~kg}$ destes tubos são usadas as seguintes quantidades de lâminas:

- aço carbono (média): $1.180 \mathrm{~kg}$; e,

- aços inoxidáveis (média): 1.064 kg.

Estes aproveitamentos diferentes estão associados às larguras e espessuras diferentes, corte, refilo, remoção de solda, faceamento, decapagem e acabamento final.

Para a produção de $1000 \mathrm{~kg}$ destes tubos são consumidos $91,4 \mathrm{kWh}$ de energia elétrica, ou seja, 329,0 MJ (1 kWh igual a 3,6 MJ); bem como 24,0 kg de gás natural, em média, na etapa de tratamento térmico. Estes dados foram obtidos em uma única empresa localizada na Grande São Paulo, que produz tubos destes diferentes tipos de aços. Justificou-se o uso da coleta de dados em uma única empresa o fato dela fabricar tubos de todos estes tipos de aços e espessuras. Como o consumo de energia elétrica e gás natural são medidos em função da produção total da empresa, não foi possível conseguir estes dados por tipo de aço utilizado.

Nesta linha de produção também são consumidos nitrogênio líquido na etapa de tratamento térmico (para gerar uma atmosfera isenta de oxigênio), água de resfriamento, graxas e outros produtos em menor escala. Estas substâncias não foram consideradas neste estudo devido à falta de dados representativos.

Em função do aproveitamento das lâminas para a produção dos tubos, os fluxos de referência apresentados na Tabela 11, página 124, deverão ser corrigidos.

A Tabela 15 apresenta as quantidades dos diferentes tipos de aços que deverão ser utilizadas no inventário do ciclo de vida dos diferentes sistemas de produto. 
Tabela 15 - Quantidades dos diferentes tipos de aços em bobinas para elaboração dos ICVs

\begin{tabular}{|l|c|c|c|c|c|c|}
\hline \multirow{2}{*}{\multicolumn{1}{|c|}{ PARÂMETROS }} & \multicolumn{6}{c|}{ SISTEMAS DE PRODUTO } \\
\cline { 2 - 7 } & Aço-C & \multicolumn{2}{c|}{$\mathbf{3 0 4}$} & \multicolumn{2}{c|}{$\mathbf{4 4 4}$} & $\mathbf{4 3 9}$ \\
\hline Espessura da Parede (mm) & 2,65 & 1,20 & 1,50 & 1,20 & 1,50 & 1,50 \\
\hline Fluxo de Referência (t de tubos) & 508,0 & 46,8 & 58,9 & 46,0 & 57,8 & 56,8 \\
\hline Fator de Multiplicação & 1,18 & \multicolumn{5}{|c|}{1,064} \\
\hline $\begin{array}{l}\text { Quantidades dos Aços em Bobinas para } \\
\text { Elaboração do ICV (t) }\end{array}$ & 599,4 & 49,8 & 62,7 & 48,9 & 61,5 & 60,4 \\
\hline
\end{tabular}

3.2.2.4 Subsistema instalação dos tubos

A instalação (fixação) dos tubos nos espelhos superior e inferior da calandra é realizada manualmente, com o auxilio de um mandril. O mandril é um equipamento movido a ar comprimido ou eletricidade. Dispõe de três ou cinco roletes, que deformam as extremidades dos tubos junto aos espelhos, fixando-os. Na fixação dos tubos com um mandril movido a energia elétrica, o consumo energético, aproximado, é:

- Para 1000 tubos em aço carbono: $7.950 \mathrm{MJ}$; e,

- Para 1000 tubos em aço inox: 6.912 MJ.

O maior consumo de energia elétrica com os tubos fabricados em aço carbono deve-se a sua maior espessura, o que ocasiona uma maior resistência mecânica à deformação.

As quantidades de tubos para os diferentes sistemas de produtos são apresentadas na Tabela 11, página 124.

A retirada dos tubos, quando da sua substituição, não requer 0 uso de energia elétrica, apenas a força física dos operários e equipamentos manuais específicos para esta operação. 


\subsubsection{Subsistema limpeza dos tubos}

Como citado anteriormente, foi considerada neste estudo a limpeza mecânica para a retirada das incrustações. Para um sistema de evaporação constituído por um pré-evaporador com nove mil tubos e mais quatro efeitos, com dois mil trezentos e setenta e sete tubos são necessários:

- 22 funcionários, trabalhando 4 horas;

- consumo de energia elétrica igual a $155 \mathrm{~kW} . \mathrm{h}$;

- consumo de água igual a 120.000 litros;

- tempo total para limpeza igual a 7 horas.

A formação das incrustações depende de inúmeros fatores, inclusive do polimento interno dos tubos. A experiência recente mostra que os tubos em aços inoxidáveis incrustam-se $50 \%$ menos que os tubos em aço carbono. Na prática isto representa que um evaporador com tubos em inox pode ser operado em condições adequadas de troca térmica por um tempo, em dias, até 50\% maior. Considerando que um evaporador com tubos em aço carbono trabalha, em média, dez dias entre as paradas para limpeza; em idênticas condições, para os diferentes tipos de aços inoxidáveis este tempo de operação seria de quinze dias. Considerando também um período anual efetivo de 210 dias e o período de avaliação de 30 anos, podem-se calcular os aspectos ambientais relativos a este subsistema, para os diferentes sistemas de produto em estudo.

A Tabela 16 apresenta estes dados.

Tabela 16 - Aspectos ambientais relativos ao subsistema limpeza dos tubos, para os diferentes sistemas de produtos

\begin{tabular}{|l|c|c|c|}
\hline \multirow{2}{*}{\multicolumn{2}{c|}{ PARÂMETROS }} & \multicolumn{2}{c|}{ SISTEMAS DE PRODUTO } \\
\cline { 2 - 4 } & Aço-C & \multicolumn{2}{c|}{ Aços Inoxidáveis } \\
\hline Espessura de Parede $(\mathrm{mm})$ & 2,65 & 1,20 & 1,50 \\
\hline Quantidade de Tubos & 12.947 & 11.885 & 12.091 \\
\hline Consumo de Água (L) & $5,29 \mathrm{E}+07$ & $3,24 \mathrm{E}+07$ & $3,29 \mathrm{E}+07$ \\
\hline Consumo de Energia Elétrica (MJ) & $2,46 \mathrm{E}+05$ & $1,51 \mathrm{E}+05$ & $1,53 \mathrm{E}+05$ \\
\hline
\end{tabular}




\subsubsection{Subsistema gás natural}

Como citado em 3.1.2.3.1, página 125, o subsistema gás natural participou na produção dos diferentes tipos de aço como redutor químico e como fonte de energia. $\mathrm{Na}$ produção dos tubos ele participou apenas como combustível, na geração de calor para a etapa de tratamento térmico. ${ }^{68,69}$

Como também foi informado em 3.2.2.3, página 137, para cada 1000 tubos fabricados são consumidos, em média, $24,0 \mathrm{~kg}$ de gás natural.

O gás natural distribuído para consumidores industriais no Brasil é uma mistura de alcanos, dos quais o metano é o que se encontra em maior porcentagem. O poder calorífico encontra-se na faixa de 35.000 a $42.000 \mathrm{~kJ} / \mathrm{m}^{3}$. Neste trabalho será adotado o valor de $38.000 \mathrm{~kJ} / \mathrm{m}^{3}\left(38 \mathrm{MJ} / \mathrm{m}^{3}\right)$.

A massa específica representativa para o gás natural é $0,66 \mathrm{~kg} / \mathrm{m}^{3}$. A partir destes dados pode-se calcular o poder calorífico do gás natural expresso por quilo, igual a $57,6 \mathrm{MJ} / \mathrm{kg}$. Complementam as especificações do gás natural comercializado no Brasil um teor de nitrogênio igual a $2 \%$ em volume e um teor máximo de enxofre igual a $70 \mathrm{mg} / \mathrm{m}^{3}$.

A combustão completa de um gás natural com esta composição pode ser representada pelas seguintes reações químicas:

$$
\begin{array}{ccc}
\mathrm{C}_{\mathrm{n}} \mathrm{H}_{2 \mathrm{n}+2}+3 / 2(\mathrm{n}+1) \mathrm{O}_{2} & \longrightarrow & \mathrm{nCO}_{2}+(\mathrm{n}+1) \mathrm{H}_{2} \mathrm{O}(\mathrm{v}) \\
\mathrm{N}+\mathrm{O}_{2} & \longrightarrow & \mathrm{NO}_{2} \\
\mathrm{~S}+\mathrm{O}_{2} & \longrightarrow & \mathrm{SO}_{2}
\end{array}
$$

A Tabela 17 relaciona os fluxos de referência para os diferentes sistemas de produto. A partir destes valores foi calculado o consumo de gás natural por sistema de produto; bem como as quantidades de calor, $\mathrm{CO}_{2}, \mathrm{NO}_{2}$ e $\mathrm{SO}_{2}$ emitidas na combustão total. 
Tabela 17 - Subsistema gás natural - contribuição aos ICVs dos diferentes sistemas de produtos

\begin{tabular}{|l|c|c|c|c|c|c|}
\hline \multirow{2}{*}{\multicolumn{1}{|c|}{ PARÂMETROS }} & \multicolumn{7}{c|}{ SISTEMAS DE PRODUTO } \\
\cline { 2 - 7 } & Aço-C & \multicolumn{2}{c|}{304} & \multicolumn{2}{c|}{$\mathbf{4 4 4}$} \\
\hline Espessura de Parede $(\mathrm{mm})$ & 2,65 & 1,20 & 1,50 & 1,20 & 1,50 & 1,50 \\
\hline Fluxos de referência $(\mathrm{t})$ & 508,0 & 46,8 & 58,9 & 46,0 & 57,8 & 56,8 \\
\hline Gás natural consumido $(\mathrm{kg})$ & $12.192,0$ & $1.212,3$ & $1.413,6$ & $1.104,0$ & $1.387,2$ & $1.363,2$ \\
\hline Energia de combustível $(\mathrm{MJ})$ & $7,02 \mathrm{E}+05$ & $6,47 \mathrm{E}+04$ & $8,14 \mathrm{E}+04$ & $6,36 \mathrm{E}+04$ & $8,00 \mathrm{E}+04$ & $7,85 \mathrm{E}+04$ \\
\hline Dióxido de Carbono Produzido $(\mathrm{g})$ & $3,29 \mathrm{E}+07$ & $3,03 \mathrm{E}+06$ & $3,81 \mathrm{E}+06$ & $2,98 \mathrm{E}+06$ & $3,74 \mathrm{E}+06$ & $3,67 \mathrm{E}+06$ \\
\hline Dióxido de Nitrogênio $(\mathrm{g})$ & $8,01 \mathrm{E}+05$ & $7,40 \mathrm{E}+04$ & $9,30 \mathrm{E}+04$ & $7,26 \mathrm{E}+04$ & $9,10 \mathrm{E}+04$ & $8,97 \mathrm{E}+04$ \\
\hline Dióxido de Enxofre $(\mathrm{g})$ & $1,13 \mathrm{E}+03$ & $1,04 \mathrm{E}+02$ & $1,31 \mathrm{E}+02$ & $1,02 \mathrm{E}+02$ & $1,28 \mathrm{E}+02$ & $1,26 \mathrm{E}+02$ \\
\hline
\end{tabular}

\subsubsection{Subsistema energia elétrica}

O subsistema energia elétrica, de importante participação nos quatro subsistemas principais, teve a sua avaliação prejudicada, por duas razões principais:

- No ICV para aço carbono ${ }^{56}$ este parâmetro não foi informado. Devido a isto, foi estimado valor 0,00E +00 , procedimento aceito pela Norma NBR ISO $14041 ; 22$ e,

- No ICV para os aços inoxidáveis, não se teve como calcular os valores de consumo de energia elétrica para a fabricação das bobinas dos aços inoxidáveis 444 e 439. Devido a isto, foi utilizado o valor informado para o aço 430 2B.

Independente destas limitações, dentre os indicadores de energia, o valor da energia primária total é mais significativo, pois representa o somatório de todos os tipos de energia utilizados.

Os consumos de energia elétrica nos subsistemas produção de tubos, instalação e limpeza de tubos foram estudados nestes subsistemas. 


\subsubsection{Subsistema transporte}

Como foi citado anteriormente, o transporte, um subsistema secundário, foi considerado em todos os sistemas de produto, na transferência das bobinas dos diferentes aços desde os centros produtores até as fábricas de tubos e destas até às usinas de açúcar, respectivamente.

O tipo de transporte considerado neste estudo foi o rodoviário, pois é o mais utilizado no Brasil para este tipo de carga. Para a coleta de dados para este subsistema, para o transporte de bobinas foi considerado o uso de carretas monoeixo, movidas a óleo diesel, com capacidade para 30 t. Entretanto, a carga máxima permitida pelo Departamento Nacional de Estradas e Rodagens (DNER) para este veículo é de 27,5 t. Uma carreta transportando $25 \mathrm{t}$, em vias pavimentadas percorre, em média, $2,0 \mathrm{~km} / \mathrm{L}$.

As bobinas de aço carbono são provenientes de uma usina distante $250 \mathrm{~km}$ da Grande São Paulo, conforme citado em 3.1.2.3.1, página 125.

A Empresa fabricante das bobinas dos diferentes tipos de aços inoxidáveis, encontra-se instalada na região ferrífera de Minas Gerais, distante $770 \mathrm{~km}$ de São Paulo.

As bobinas de aços inoxidáveis pesam $6 \mathrm{t}$ cada uma, enquanto que as de aço carbono, 12 t, em média.

Para a estimativa de consumo de óleo diesel no transporte dos tubos, foi considerado o envio dos mesmos a uma usina de açúcar localizada na Região da Alta Mogiana, distante 430 km de São Paulo. Foram usados caminhões "truck", com capacidade para $14 \mathrm{t}$. Este tipo de veículo carregado percorre, em média, 3,2 km/L.

Tendo em vista a ausência de dados precisos e confiáveis de um ICV que pudesse retratar todos os aspectos ambientais associados ao transporte rodoviário no Brasil, optou-se por considerar apenas os aspectos ambientais relacionados à combustão do óleo diesel pelas carretas e caminhões "truck".

A composição química típica de um óleo diesel ${ }^{2}$ é:

C: $87 \% ; H: 12,6 \%$; O: $0,04 \% ; \mathrm{N}: 0,006 \%$ e S: $0,22 \%$. 
A combustão completa do óleo diesel acarreta, esquematicamente, as seguintes reações:

$$
\begin{gathered}
\mathrm{C}+\mathrm{O}_{2} \\
2 \mathrm{H}+{ }^{1 / 2} \mathrm{O}_{2} \\
\mathrm{~N}+\mathrm{O}_{2} \\
\mathrm{~S}+\mathrm{O}_{2}
\end{gathered}
$$

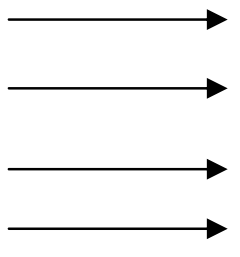

$\mathrm{CO}_{2}$

$\mathrm{H}_{2} \mathrm{O}$

$\mathrm{NO}_{2}$

$\mathrm{SO}_{2}$

O poder calorífico inferior para um óleo diesel com esta composição é, tipicamente, $10.950 \mathrm{kcal} / \mathrm{kg}$. A densidade deste combustível é $0,85 \mathrm{~kg} / \mathrm{L}$, aproximadamente.

A compilação de todos os dados apresentados neste subsistema é mostrada

\begin{tabular}{|c|c|c|c|c|c|c|}
\hline \multirow{3}{*}{$\begin{array}{l}\text { PARÂMETROS } \\
\text { Espessura de Parede }(\mathrm{mm})\end{array}$} & \multicolumn{6}{|c|}{ SISTEMAS DE PRODUTO } \\
\hline & Aço-C & \multicolumn{2}{|c|}{304} & \multicolumn{2}{|c|}{444} & \multirow{2}{*}{$\begin{array}{c}439 \\
1,50\end{array}$} \\
\hline & 2,65 & 1,20 & 1,50 & 1,20 & 1,50 & \\
\hline $\begin{array}{l}\text { Distâncias Usinas Siderúrgicas - } \\
\text { Fábricas de Tubos }(\mathrm{km})\end{array}$ & 250 & \multicolumn{5}{|c|}{770} \\
\hline $\begin{array}{l}\text { Quantidades de bobinas de aço } \\
\text { transportadas (t) }\end{array}$ & 599,4 & 49,8 & 62,7 & 48,9 & 61,5 & 60,4 \\
\hline Consumo óleo diesel (L) & $3.121,9$ & 798,9 & $1.005,8$ & 784,4 & 986,6 & 968,9 \\
\hline $\begin{array}{l}\text { Distância Fábrica Tubos - Usina de } \\
\text { Açúcar }(\mathrm{km})\end{array}$ & \multicolumn{6}{|c|}{430} \\
\hline Quantidades de tubos transportados (t) & 508,0 & 46,8 & 58,9 & 46,0 & 57,8 & 56,8 \\
\hline Consumo óleo diesel (L) & $5.688,5$ & 524,1 & 659,6 & 515,1 & 647,2 & 636,0 \\
\hline Consumo total óleo diesel (L) & $8.810,4$ & $1.323,0$ & $1.665,4$ & $1.299,5$ & $1.633,8$ & 1.605 \\
\hline Energia de Combustível (MJ) & $3,43 E+05$ & $5,16 \mathrm{E}+04$ & $6,50 \mathrm{E}+04$ & $507 \mathrm{E}+04$ & $6,38 \mathrm{E}+04$ & $6,26 \mathrm{E}+04$ \\
\hline Dióxido de Carbono produzido (g) & $2,39 \mathrm{E}+07$ & $3,59 \mathrm{E}+06$ & $4,52 \mathrm{E}+06$ & $3,52 \mathrm{E}+06$ & $4,43 E+06$ & $4,35 \mathrm{E}+06$ \\
\hline Dióxido de Enxofre produzido (g) & $3,30 \mathrm{E}+04$ & $4,95 \mathrm{E}+03$ & $6,23 \mathrm{E}+03$ & $4,88 \mathrm{E}+03$ & $6,11 \mathrm{E}+03$ & $6,00 \mathrm{E}+03$ \\
\hline Dióxido de nitrogênio produzido (g) & $1,48 \mathrm{E}+03$ & $2,22 \mathrm{E}+02$ & $2,79 \mathrm{E}+02$ & $2,18 \mathrm{E}+02$ & $2,27 \mathrm{E}+02$ & $2,69 \mathrm{E}+02$ \\
\hline
\end{tabular}
na Tabela 18. Estas informações serão utilizadas nos ICVs para todos os sistemas de produto em estudo.

Tabela 18 - Subsistema transporte - contribuição aos ICVs dos diferentes sistemas de produto

${ }^{2}$ CRC/ANP. Composição química do óleo diesel: resposta № 158951. [mensagem pessoal]. Mensagem recebida por: linojose@uol.com.br em 06 de mar. 2007. 
Concluída a fase de Inventário do Ciclo de Vida para o presente estudo, foram geradas planilhas de aspectos ambientais, individualizadas para cada sistema de produto, como recomendam as Normas ABNT NBR ISO 14.040:200124 e ABNT NBR ISO 14.041:2004 ${ }^{22}$. Os dados apresentados nestas planilhas consideraram todos os subsistemas e foram normalizados com relação à unidade funcional e aos fluxos de referência (ver Tabela 11, página 124), bem como às perdas dos aços que acontecem na fabricação dos tubos (ver Tabela 15, página 139).

Estas planilhas são apresentadas nos Apêndices C, D, E, F, G e H, respectivamente.

Nestas planilhas os subsistemas energia elétrica e gás natural não foram apresentados separadamente, pois os aspectos ambientais a eles relacionados foram considerados nos subsistemas produção de tubos, instalação de tubos e limpeza de tubos.

O Apêndice I reúne os dados consolidados dos inventários de ciclo de vida para todos os sistemas de produtos em estudo. 


\subsection{AVALIAÇÃO DO IMPACTO DO CICLO DE VIDA}

Nos estudos desenvolvidos pelo International Iron Steel Institute sobre AICV para aço carbono, que levaram a publicação do "World Steel Life Cycle Inventory" "66, referência mundial sobre o assunto, foram computados quarenta e dois aspectos ambientais, conforme apresentado no Apêndice A. No trabalho do $\|\left. S\right|^{56}$, tendo em vista a importância relativa dos aspectos ambientais analisados, as etapas referentes à correlação dos dados de inventário por categorias de impacto (classificação), a modelagem destes dados dentro das categorias de impacto (caracterização); bem como uma possível agregação destes resultados (ponderação) foram substituídas pela seleção de sete aspectos ambientais. Os aspectos ambientais selecionados foram:

- Dióxido de Carbono $\left(\mathrm{CO}_{2}\right)$;

- Óxidos de nitrogênio $\left(\mathrm{NO}_{\mathrm{x}}\right)$;

- Materiais particulados;

- Óxidos de enxofre $\left(\mathrm{SO}_{\mathrm{x}}\right)$;

- Materiais suspensos;

- Resíduos totais; e,

- Energia primária total.

Esta abordagem objetivou concentrar as atenções dos estudos de ACV envolvendo os processos siderúrgicos e seus produtos nos aspectos ambientais que, potencialmente, ocasionam os maiores impactos ambientais e que merecem, portanto, atenção especial dos interessados pelo assunto.

De forma semelhante ao trabalho desenvolvido pelo $\|\left.\mathrm{IS|}\right|^{56}$, foi usada nesta tese de doutorado uma avaliação de desempenho ambiental para os diferentes sistemas de produto de tubos de aço em análise, considerando os mesmos aspectos ambientais citados anteriormente. Esta escolha é justificada, pois os subsistemas produção das bobinas de aço carbono e das bobinas dos aços inoxidáveis contribuem quali e quantitativamente com $90 \%$ dos aspectos ambientais avaliados, aproximadamente. 
A estes sete aspectos ambientais foram acrescidos mais dois, a saber:

- somatório dos recursos naturais não renováveis consumidos; e;

- consumo total de água.

As justificativas para a seleção destes nove aspectos ambientais foram: ${ }^{56}$

- Dióxido de carbono $\left(\mathrm{CO}_{2}\right)$ - o aquecimento global é uma das categorias de impacto ambiental que tem merecido a maior atenção em todo o mundo e a emissão deste gás é a que mais tem contribuído para esta categoria de impacto ambiental. Na usina siderúrgica, o alto forno e o processo de sintetização são os maiores geradores de $\mathrm{CO}_{2}$. Fora da usina, a geração da termoeletricidade, a coqueificação, a calcinação dos calcários e os diferentes tipos de transporte utilizados são os principais emissores deste gás.

- Óxidos de nitrogênio $\left(\mathrm{NO}_{\mathrm{x}}\right)$ - estes gases estão associados ao aquecimento global e contribuem também para outras categorias de impacto ambiental, tais como a acidificação, a eutrofização, a formação de oxidantes fotoquímicos e a toxicidade humana. Transporte domina a emissão destes gases, em especial o marítimo. A produção do coque, a sinterização e a produção da termoeletricidade são os demais geradores de $\mathrm{NO}_{\mathrm{x}}$.

- Materiais particulados - este aspecto ambiental tem merecido atenção crescente das usinas tendo em vista a sua ação altamente poluidora. A peletização do minério de ferro, a sinterização e a produção de aço via FEA são os maiores emissores. Fora do ambiente da usina siderúrgica, a produção da termoeletricidade e de minério de ferro são os processos que mais contribuem nesta emissão.

- Óxidos de enxofre $\left(\mathrm{SO}_{\mathrm{x}}\right)$ - a produção de eletricidade via termoelétricas domina a geração destes gases, seguido pela produção de sinter e o transporte marítimo. A produção dos aços inoxidáveis via FEA consome muita eletricidade. Os países que participam do estudo de ICV para os aços inoxidáveis ${ }^{57}$ (USA, Europa e Ásia) tem em sua matriz energética uma maior participação da termoeletricidade. Este não é o caso brasileiro, já que o maior fabricante de aços inoxidáveis no Brasil, responsável pela fabricação de $90 \%$ destes aços, é uma usina integrada localizada na região ferrífera de Minas Gerais, que utiliza carvão vegetal proveniente de reflorestamento. As outras duas usinas que produzem aços 
inoxidáveis no Brasil, localizadas nos Estado de São Paulo e Rio Grande do Sul, utilizam sucatas e ferro-ligas como matéria-prima e consomem energia elétrica proveniente de uma matriz energética com 84\% correspondente à hidroelétricas. Isto posto, os dados referentes à emissão de $\mathrm{SO}_{\mathrm{x}}$ na produção dos aços inoxidáveis utilizados nesta tese de doutorado estão super valorizados frente a realidade brasileira ${ }^{3}$.

- Materiais suspensos - as operações de laminação a quente são os maiores emissores aquosos de materiais suspensos e óleo, seguido do processo de sinterização.

- Resíduos totais - as operações de mineração de carvão, minério de ferro e calcários contribuem com aproximadamente $90 \%$ dos resíduos totais, tanto na forma de resíduos rochosos e lagoas de decantação. Na usina siderúrgica, o altoforno e as etapas de refino do gusa fundido e forno elétrico a arco produzem escórias sólidas que são aproveitadas pela indústria cimenteira.

- Energia primária total - a produção das lâminas dos diferentes tipos de aços considerados neste estudo consumiu mais que $87 \%$ de toda a energia primária total utilizada ao longo do ciclo de vida dos diferentes tipos de tubos de aço. A energia usada na fabricação das lâminas de aço foi gerada, em boa parte, pela queima do carvão, quer seja nos alto-fornos ou na geração da termoeletricidade, (ver “energia combustível”, item 3.2.2.1, página 132).

${ }^{3}$ O Sistema Elétrico Nacional e a Necessidade Nuclear. Autor: Othon Luiz Pinheiro da Silva - Diretor Presidente da Eletrobrás Termonuclear S. A. (ELETRONUCLEAR) Energy Summit 2006 - The Brasilian Energy Meeting Place.

Dados para final de 2005, relativos a geração de energia elétrica

\begin{tabular}{|l|c|c|}
\hline \multicolumn{1}{|c|}{ Fontes de Eletricidade } & Mundo & Brasil \\
\hline Hídrica & 20,0 & 84,4 \\
\hline Carvão & 40,0 & 1,5 \\
\hline Gás Natural + Derivados de Petróleo & 20,0 & 6,8 \\
\hline
\end{tabular}

Fonte: www.energysummit.com.br/noticias/noticias 003.asp-59k- 
- Somatório dos recursos naturais consumidos - fazem parte deste item todos os recursos naturais utilizados pelas usinas que participaram dos estudos do $\left.I I S\right|^{56} \mathrm{e}$ do ISSF $^{57}$, listados no Apêndice I, a saber:

- Carvão mineral (metalúrgico);

- Lignita (carvão fóssil sub betuminoso);

- Minérios de ferro, cromo, níquel, molibdênio e manganês;

- Calcita/dolomita;

- Óleo bruto;

- Gás natural.

Desta relação cabe salientar a escassez crescente dos carvões metalúrgicos de qualidade, o que tem levado ao uso de carvões com teores mais elevados de enxofre (fonte de $\mathrm{SO}_{\mathrm{x}}$ ) e que exigem sofisticadas etapas de beneficiamento, com impactos ambientais significativos (emissão de materiais particulados e materiais suspensos, grande consumo de água tratada e de energia). Além disso, é preocupante a escassez dos minérios de níquel e molibdênio.

- Consumo total de água - este recurso natural considerado por muitos como "renovável", deverá ser o primeiro a faltar em boa parte do mundo. Ainda predomina a emissão da água contaminada, sem nenhum tratamento ou com tratamento insuficiente para torná-la adequada ao consumo humano, o que tem levado a crescente poluição dos rios, lagos e oceanos. É importante lembrar que, mesmo quando a água é tratada, isto se faz em grandes áreas, com consumo de produtos químicos e energia, e gera resíduos e emissões que precisam receber destinações adequadas. 


\subsection{RESULTADOS}

Os dados apresentados nos Apêndices C, D, E, F, G e H, relativos aos seis sistemas de produto em estudo mostram que os subsistemas relativos a produção das lâminas de aço carbono e aços inoxidáveis são responsáveis por mais que 87\% das emissões sólidas, líquidas e gasosas; bem como pelo consumo dos recursos naturais não renováveis e energia primária total.

A Tabela 19 apresenta os valores numéricos relativos aos sistemas de produto em estudo, para os nove aspectos ambientais selecionados, extraídos do Apêndice I. Complementam os dados extraídos do Apêndice I os fluxos de referência para os sistemas de produto, que informam as quantidades de tubos utilizados durante o ciclo de vida do estudo e as quantidades de bobinas de aços utilizadas na fabricação destes tubos de aço.

Estes dados permitem formular uma avaliação ambiental objetiva, de fácil execução, que dispensa o uso de "softwares" ou programas específicos para tal, nem sempre disponíveis ou de fácil utilização.

Tabela 19 - Avaliação ambiental dos sistemas de produto tubos em aço carbono e tubos em aços inoxidáveis 304, 444 e 439

\begin{tabular}{|c|c|c|c|c|c|c|c|}
\hline \multirow{3}{*}{ Aspecto Ambiental } & \multirow{3}{*}{$\begin{array}{l}\text { Unidade } \\
\text { (mm) }\end{array}$} & \multicolumn{6}{|c|}{ Sistemas de Produto } \\
\hline & & \multirow{2}{*}{$\begin{array}{c}\text { Aço-C } \\
2,65\end{array}$} & \multicolumn{2}{|c|}{304} & \multicolumn{2}{|c|}{444} & \multirow{2}{*}{$\begin{array}{l}439 \\
1,50\end{array}$} \\
\hline & & & 1,20 & 1,50 & 1,20 & 1,50 & \\
\hline Dióxido de Carbono $\left(\mathrm{CO}_{2}\right)$ & g & $1,37 \mathrm{E}+09$ & $3,11 E+08$ & $3,90 \mathrm{E}+08$ & $2,65 \mathrm{E}+08$ & $3,37 \mathrm{E}+08$ & $3,38 \mathrm{E}+08$ \\
\hline Óxidos de Nitrogênio $\left(\mathrm{NO}_{\mathrm{x}}\right)$ & g & $2,38 \mathrm{E}+06$ & $7,82 \mathrm{E}+05$ & $9,84 \mathrm{E}+05$ & $7,05 \mathrm{E}+05$ & $8,86 \mathrm{E}+05$ & $8,72 \mathrm{E}+05$ \\
\hline Materiais Particulados & g & $1,07 \mathrm{E}+06$ & $3,45 E+05$ & $4,35 \mathrm{E}+05$ & $2,79 \mathrm{E}+05$ & $3,51 E+05$ & $3,45 \mathrm{E}+05$ \\
\hline Óxidos de Enxofre $\left(\mathrm{SO}_{\mathrm{x}}\right)$ & g & $1,45 \mathrm{E}+06$ & $2,31 E+06$ & $2,93 \mathrm{E}+06$ & $1,11 \mathrm{E}+06$ & $1,40 \mathrm{E}+06$ & $1,40 \mathrm{E}+06$ \\
\hline Materiais Suspensos & g & $1,08 \mathrm{E}+05$ & $1,95 \mathrm{E}+03$ & $2,46 \mathrm{E}+03$ & $6,61 \mathrm{E}+03$ & $8,31 \mathrm{E}+03$ & $8,16 \mathrm{E}+03$ \\
\hline Resíduos Totais & $\mathrm{kg}$ & $9,56 \mathrm{E}+05$ & $1,67 E+05$ & $2,10 \mathrm{E}+05$ & $6,83 \mathrm{E}+04$ & $8,59 \mathrm{E}+04$ & $8,44 \mathrm{E}+04$ \\
\hline Energia Primária Total & MJ & $1,64 \mathrm{E}+07$ & $3,06 \mathrm{E}+06$ & $3,79 \mathrm{E}+06$ & $2,59 \mathrm{E}+06$ & $3,20 \mathrm{E}+06$ & $3,32 E+06$ \\
\hline $\begin{array}{l}\text { Recursos Naturais não } \\
\text { Renováveis Consumidos }\end{array}$ & $\mathrm{kg}$ & $1,55 \mathrm{E}+06$ & $1,24 \mathrm{E}+05$ & $1,57 \mathrm{E}+05$ & $1,17 \mathrm{E}+05$ & $1,40 \mathrm{E}+05$ & $1,42 E+05$ \\
\hline Água Usada Total & $\mathrm{L}$ & $6,29 \mathrm{E}+07$ & $3,33 \mathrm{E}+07$ & $3,40 \mathrm{E}+07$ & $3,34 \mathrm{E}+07$ & $3,42 \mathrm{E}+07$ & $3,41 \mathrm{E}+07$ \\
\hline Fluxo de Referência & $\mathrm{t}$ & 508,0 & 46,8 & 58,9 & 46,0 & 57,8 & 56,8 \\
\hline $\begin{array}{l}\text { Massas dos Aços em } \\
\text { Bobinas - Elaboração ICVs }\end{array}$ & $\mathrm{t}$ & 599,4 & 49,8 & 62,7 & 48,9 & 61,5 & 60,4 \\
\hline
\end{tabular}




\subsection{DISCUSSÃO}

Ao se analisar os dados da Tabela 19, constata-se que para os aspectos ambientais "dióxido de carbono", "óxidos de nitrogênio", "materiais particulados", "energia primária total", "recursos naturais não renováveis consumidos" e "água total" os valores numéricos relativos aos sistemas de produtos tubos em aços inoxidáveis encontram-se em uma mesma faixa de grandeza. Nestes casos, foram usados os valores "médios" para estes sistemas de produtos, quando comparados aos sistemas de produto tubos em aço carbono com 2,65 mm de espessura. Para os aspectos ambientais "materiais suspensos" e "resíduos totais", como os valores numéricos variam significativamente para os sistemas de produtos tubos em aços inoxidáveis, foram usados os valores máximos, correspondentes ao sistema de produto tubos em aços inoxidável $444 \mathrm{com} 1,50 \mathrm{~mm}$ de espessura. $O$ aspecto ambiental "óxidos de enxofre" recebeu, uma análise em separado. Desta forma, temos que o sistema de produto tubos em aço carbono com 2,65 mm de espessura, quando comparado com os sistemas de produtos tubos em aços inoxidável $304 \mathrm{e}$ $444 \mathrm{com} \mathrm{1,20} \mathrm{mm} \mathrm{e} \mathrm{1,50} \mathrm{mm} \mathrm{de} \mathrm{espessura,} \mathrm{respectivamente,} \mathrm{e} \mathrm{com} \mathrm{o} \mathrm{sistema} \mathrm{de}$ produto tubos em aços inoxidável $439 \mathrm{com} 1,50 \mathrm{~mm}$ de espessura emite mais que:

- 4,2 vezes a quantidade de dióxido de carbono;

- 2,8 vezes a quantidade de óxidos de nitrogênio;

- 3,1 vezes a quantidade de materiais particulados;

- 13,0 vezes a quantidade de materiais suspensos; e,

- 4,5 vezes a quantidade de resíduos totais.

De forma semelhante, o sistema de produtos tubos em aço carbono com 2,65 $\mathrm{mm}$ de espessura, quando comparado com a média dos valores relativos aos sistemas de produtos tubos em aço inoxidáveis consome mais que:

- 11 vezes a quantidade de recursos naturais não renováveis;

- 1,8 vezes a quantidade total de água utilizada; $\mathrm{e}$,

- 5 vezes a quantidade de energia primária total.

Com relação ao aspecto ambiental "óxidos de enxofre", o sistema de produtos tubos em aço carbono emitiu quantidades semelhantes destes gases quando 
comparado aos sistemas de produtos tubos em aços inoxidável 444 e 439 e emitiu a metade, aproximadamente, quando comparado aos sistemas de produto tubos em aços inoxidável 304.

Cabe aqui ressaltar que as emissões de "óxidos de enxofre" dos sistemas de produto tubos em aços inoxidáveis informadas neste estudo estão superestimadas, tendo em vista a matriz energética dos países em que os dados de ICV foram coletadas ter uma predominância da termoeletricidade. 


\section{CUSTEIO DO CICLO DE VIDA}

O objetivo do CCV é oferecer ao engenheiro, ao empresário moderno e ao homem público uma ferramenta gerencial para a seleção de produtos ou serviços, que contabiliza os custos totais do sistema em análise, desde a sua concepção, até o fim de sua vida útil, ou seja, ao longo do seu ciclo de vida. Nesta abordagem são considerados os custos relativos ao projeto, aquisição, produção, transporte, instalação, operação, manutenções, desativação, reposição, reúso ou reciclagem dos materiais residuais, valores obtidos pela venda destes materiais, bem como o que se deixou de ganhar em termos financeiros ou dano ao público usuário pelas horas não trabalhadas. O somatório de todos estes custos permitirá selecionar a alternativa mais adequada econômica e financeiramente. Como o ciclo de vida de um sistema pode durar décadas, todos os custos incorridos neste período precisam ser tratados dentro do conceito do custo do dinheiro no tempo.

Para a elaboração deste estudo de CCV foram utilizados os procedimentos informados em 2.4, página 72, que resumiu as orientações presentes na bibliografia consultada, ${ }^{3,33,34,35,36}$ a seguir detalhadas: 


\subsection{DEFINIÇÃO DA UNIDADE E SISTEMA EM ESTUDO}

ACV e CCV são ferramentas gerenciais que se complementam. A primeira trata da avaliação ambiental de produtos ou serviços, enquanto que a segunda, a avaliação econômico-financeira destes mesmos itens. Elas têm em comum a avaliação destes parâmetros ao longo do ciclo de vida destes itens, avaliação esta realizada através da confecção de inventários detalhados que objetivam cobrir todas as etapas que compõem o ciclo de vida em estudo. Independente destas semelhanças, alguns termos, mesmo que semelhantes, apresentam significados e aplicações diferentes. Cabe citar as conceituações de sistema e unidade:

Para os estudos de CCV, sistema é conjunto de unidades do processo, com objetivos e características definidas, inter-relacionadas fisicamente, que se complementam no sentido de se alcançar um propósito definido. Neste capítulo, como unidade tem-se os tubos metálicos usados em um evaporador para usinas de açúcar, enquanto que sistema é todo o evaporador. No caso específico, o sistema evaporador para usina de açúcar é composto de várias outras unidades, tais como espelhos superior e inferior, carcaça, visores e lunetas, separador de arraste, entre outros. O propósito principal deste sistema é evaporar parte da água presente no caldo de cana. 


\subsection{ESTIMATIVA DO CICLO DE VIDA}

A segunda etapa de um estudo de CCV consiste em estimar a vida econômica da unidade objeto do estudo e da totalidade do sistema onde ela se insere.

A Tabela 20 apresenta a vida econômica média de tubos em aço carbono com 2,65 mm de espessura e, comparativamente, dos tubos fabricados com os aços inoxidáveis 304, 444 e 439, nas espessuras de 1,20 e 1,50 mm, respectivamente.

Tabela 20 - Estimativa da vida útil do sistema e da unidade em estudo dos tubos de aço usados nos evaporadores para usinas de açúcar

\begin{tabular}{|c|c|c|c|}
\hline \multicolumn{4}{|c|}{ ESTIMATIVA DO CICLO DE VIDA } \\
\hline SISTEMA & VIDA ÚTIL & UNIDADE & VIDA ÚTIL \\
\hline \multirow{4}{*}{$\begin{array}{l}\text { Evaporador } \\
\text { Usina de Açúcar }\end{array}$} & \multirow{4}{*}{60 anos } & $\begin{array}{c}\text { Tubo aço carbono com } \\
2,65 \mathrm{~mm}\end{array}$ & 6 anos \\
\hline & & $\begin{array}{c}\text { Tubo em inox } 304 \mathrm{com} \\
1,20 \text { e } 1,50 \mathrm{~mm}\end{array}$ & \multirow{3}{*}{30 anos } \\
\hline & & $\begin{array}{c}\text { Tubo em inox } 444 \mathrm{com} \\
1,20 \text { e } 1,50 \mathrm{~mm}\end{array}$ & \\
\hline & & $\begin{array}{c}\text { Tubo em inox } 439 \mathrm{com} \\
1,50 \mathrm{~mm}\end{array}$ & \\
\hline
\end{tabular}

As justificativas para as estimativas dos ciclos de vida das unidades apresentadas nesta tabela, foram analisadas anteriormente no item 3.1.2.3, página 121.

A vida útil estimada para o sistema evaporador usina de açúcar baseou-se na grande durabilidade da sua carcaça, unidade deste sistema que mais o caracteriza.

A carcaça em aço carbono, resiste ao ambiente em que se encontra devido, principalmente, a grande espessura da sua parede, que pode chegar a mais de $20 \mathrm{~mm}$.

A Tabela 21 apresenta algumas especificações dos tubos de aço que compõem as unidades deste estudo; bem como o número de tubos e a massa dos mesmos que compõe os evaporadores para usinas de açúcar. 
Tabela 21 - Especificações dos tubos de aço utilizados neste estudo e os números e massas dos mesmos usados, nos evaporadores para usinas de açúcar

\begin{tabular}{|c|c|c|c|c|c|c|c|}
\hline \multirow{2}{*}{\multicolumn{2}{|c|}{ PARÂMETROS }} & \multicolumn{6}{|c|}{ UNIDADES - Tubos em: } \\
\hline & & \multirow{2}{*}{$\frac{\text { Aço-C }}{2,65}$} & \multicolumn{2}{|c|}{304} & \multicolumn{2}{|c|}{444} & 439 \\
\hline \multicolumn{2}{|c|}{ Espessura de parede $(\mathrm{mm})$} & & 1,20 & 1,50 & 1,20 & 1,50 & 1,50 \\
\hline \multicolumn{2}{|c|}{$\begin{array}{l}\text { Superfície Interna para Troca } \\
\text { Térmica }\left(\mathrm{m}^{2} / \mathrm{m}\right)\end{array}$} & 0,1030 & 0,1122 & 0,1103 & 0,1122 & 0,1103 & 0,1103 \\
\hline \multicolumn{2}{|c|}{ Massa por Metro Linear $(\mathrm{kg} / \mathrm{m})$} & 2,32 & 1,11 & 1,37 & 1,09 & 1,35 & 1,32 \\
\hline \multicolumn{2}{|c|}{ Densidade $\left(\mathrm{g} / \mathrm{cm}^{3}\right)$} & 7,8 & \multicolumn{2}{|c|}{8,1} & \multicolumn{2}{|c|}{7,8} & 7,7 \\
\hline \multirow{2}{*}{$\begin{array}{l}1^{0} \\
\text { Efeito }\end{array}$} & №. Tubos & 4.958 & 4.551 & 4.630 & 4.551 & 4.630 & 4.630 \\
\hline & Massa do Efeito (t) & 46,0 & 20,2 & 25,4 & 19,8 & 24,8 & 24,5 \\
\hline \multirow{2}{*}{$\begin{array}{l}2^{0}-5^{0} \\
\text { Efeito }\end{array}$} & №. Tubos & 7.989 & 7.334 & 7.461 & 7.334 & 7.461 & 7.461 \\
\hline & Massa dos 4 Efeitos (t) & 55,6 & 24,4 & 30,7 & 24,0 & 30,2 & 29,6 \\
\hline \multicolumn{2}{|c|}{ Massa Total da Unidade (t) } & 101,6 & 44,6 & 56,1 & 43,8 & 55,0 & 54,1 \\
\hline \multicolumn{2}{|c|}{ №. total de tubos na Unidade } & 12.947 & 11.885 & 12.091 & 11.885 & 12.091 & 12.091 \\
\hline
\end{tabular}

A Tabela acima, originária da Tabela 11, página 124, revela os parâmetros que serão usados no CCV em andamento. Destes, a espessura de parede dos tubos que constituem as unidades deste estudo ocasiona duas importantes características que merecem ser analisadas.

\subsubsection{Massa por metro linear dos tubos}

A maior espessura de parede dos tubos, em especial os de aço carbono, ocasiona um aumento significativo na relação "massa por metro linear", sendo que a massa da unidade "tubos em aço carbono com 2,65 mm de espessura" chega a ser $232 \%$ maior que a massa da unidade "tubos em aço inox 444 com 1,20 mm". Esta grande diferença, associada à maior freqüência de troca destes tubos, ocasionou, uma maior despesa com a compra e o transporte destes tubos, além de inúmeros outros custos e despesas de mais difícil mensuração, das quais se pode citar: 
- redução na espessura de parede da carcaça dos evaporadores, em especial se a carcaça for em chapa de aço inox, já que a estrutura do evaporador poderá ser menor;

- estrutura para fixação e sustentação do evaporador mais simples e de menor resistência mecânica (e menor custo);

- redução na massa de material a ser movimentada no período de manutenção destes equipamentos;

- redução na área de estocagem destes materiais.

\subsubsection{Superfície interna para troca térmica}

A maior espessura de parede dos tubos de aço carbono reduz o diâmetro interno dos mesmos e, conseqüentemente, reduz a superfície interna para troca térmica. Em função disto, para tubos com $38,10 \mathrm{~mm}$ de diâmetro externo, os tubos em aços inoxidáveis com 1,50 e 1,20 mm de espessura possuem superfícies internas para troca térmica 7,1 e $8,9 \%$ maiores, respectivamente, que os tubos em aço carbono com 2,65 $\mathrm{mm}$ de espessura.

Esta importante característica dos tubos em aços inoxidáveis ocasionará outras vantagens aos evaporadores montados com eles. As principais são:

- redução no número de tubos para uma mesma superfície de troca;

- redução nos custos de instalação e substituição;

- redução nos custos e tempos gastos para as limpezas;

- redução no tamanho dos evaporadores;

- mantido o mesmo número de tubos ou o mesmo comprimento total dos tubos, aumento na capacidade de evaporação, bastando para isto aumentar a entrada de vapor. 


\subsection{ELABORAÇÃO DO INVENTÁRIO}

$\mathrm{Na}$ elaboração deste inventário foram adotadas várias premissas, algumas delas já explicadas e justificadas no item 3.1.2.3, página 121. Em resumo elas são:

- superfície total de troca térmica do sistema evaporador igual a $4.400 \mathrm{~m}^{2}$, sendo um pré-evaporador com $2.000 \mathrm{~m}^{2}$ e quatro efeitos com $600 \mathrm{~m}^{2}$ cada um;

- os tubos do pré-evaporador e dos efeitos possuem comprimento útil para troca térmica igual a $3.916,5$ e $2.916,5 \mathrm{~mm}$, respectivamente;

- vida útil média dos tubos em aço carbono igual a seis anos;

- vida útil média dos tubos em aço inox igual a 30 anos;

- período de tempo do estudo de CCV para as unidades igual a 30 anos;

- período anual efetivo de operação das usinas de açúcar igual a 210 dias;

- todos os custos foram levantados em março de 2007.

Independente de terem sido visitadas várias usinas de açúcar, para o cálculo dos custos e despesas relativas à instalação, substituição e limpeza dos tubos foram usados os dados originários de uma usina de grande porte localizada na região da Alta Mogiana, distante $430 \mathrm{~km}$ da cidade de São Paulo. Justificaram esta prática os seguintes fatores, principalmente:

- a dificuldade em se conseguir informações completas em algumas usinas;

- esta usina começou a usar aço inox na safra de 2000. Como não existia na região uma experiência consolidada, começou testando o aço inoxidável 316 e, posteriormente, os inox 444 e 439. A partir daquela safra, esta usina vem substituindo os tubos em aço carbono, tendo agora optado pelo uso de tubos em inox 439 nos primeiro, segundo e terceiro efeitos, e inox 444 no quarto efeito.

- a impossibilidade de se estabelecer valores "médios" com relação aos tempos para instalação, substituição e limpeza dos tubos dos evaporadores, bem como aproveitamento e custo da mão de obra e utilidades. Em suma, cada usina apresenta um comportamento distinto.

A partir destas premissas, o inventário foi elaborado. 


\subsubsection{Preços dos tubos para evaporadores}

Em março de 2007 foi solicitado orçamento à nove fabricantes de tubos para evaporadores de usinas de açúcar nos aços inoxidáveis 304 e 444, com espessuras de parede iguais a 1,20 e 1,50 mm, bem como no inox 439, com 1,50 mm de espessura. Foi especificado também que os tubos deveriam ser com costura, ter $38.10 \mathrm{~mm}$ de diâmetro externo e que a temperatura de uso variava de 55 a $135^{\circ} \mathrm{C}$. Na mesma época, foram solicitados orçamentos para quatro fabricantes de tubos em aço carbono para o mesmo fim, com espessura de parede igual a 2,65 $\mathrm{mm}$ e demais especificações idênticas às dos tubos em inox..

Os valores orçados deveriam incluir todos os impostos, serem "fob" São Paulo e serem apresentados por quilo e por metro linear de tubo.

A Tabela 22 apresenta os valores orçados por oito fabricantes de tubos em aços inoxidáveis. Destes, um deles é uma empresa integrada, que fabrica desde o aço a partir do minério de ferro até os tubos. Os demais fabricam os tubos a partir das lâminas compradas no Brasil ou no exterior. Todos estes fabricantes informaram atender às Normas ASTM A 249 ou ASTM A 269. O nome destes fabricantes foi preservado, tendo sido substituído por letras. 
Tabela 22 - Preços dos diferentes tubos de aços inoxidáveis 439, 444 e 304 com diferentes espessuras, para uso em evaporadores de usinas de açúcar

\begin{tabular}{|c|c|c|c|c|c|c|c|c|c|c|}
\hline \multirow{4}{*}{$\begin{array}{c}\text { Tipo de Aço } \\
\begin{array}{c}\text { Espessura } \\
(\mathrm{mm})\end{array} \\
\text { FORNECEDOR }\end{array}$} & \multicolumn{10}{|c|}{ CUSTO UNITÁRIO (R\$) } \\
\hline & \multirow{2}{*}{\multicolumn{2}{|c|}{$\begin{array}{c}439 \\
1,50\end{array}$}} & \multicolumn{4}{|c|}{444} & \multicolumn{4}{|c|}{304} \\
\hline & & & \multicolumn{2}{|c|}{1,20} & \multicolumn{2}{|c|}{1,50} & \multicolumn{2}{|c|}{1,20} & \multicolumn{2}{|c|}{1,50} \\
\hline & kg & $\mathbf{m}$ & kg & $\mathbf{m}$ & kg & $\mathbf{m}$ & kg & $\mathbf{m}$ & kg & $\mathbf{m}$ \\
\hline$A$ & 14,52 & 19,17 & 19,16 & 20,88 & 18,82 & 25,41 & - & - & - & - \\
\hline B & - & - & - & - & - & - & 25,35 & 28,14 & 25,37 & 34,76 \\
\hline $\mathrm{C}$ & 15,96 & 21,07 & 19,64 & 21,40 & 19,64 & 26,51 & 25,73 & 28,56 & 25,73 & 35,24 \\
\hline$D$ & - & - & - & - & - & - & 25,35 & 28,14 & 25,45 & 34,86 \\
\hline$E$ & - & - & - & - & - & - & 27,09 & 30,02 & - & - \\
\hline$F$ & 13,28 & 18,26 & 19,35 & 21,44 & 19,03 & 26,15 & 25,49 & 28,25 & 25,33 & 34,80 \\
\hline G & - & - & - & - & - & - & 31,44 & 34,90 & 31,15 & 42,68 \\
\hline $\mathrm{H}$ & - & - & - & - & - & - & 26,48 & 29,39 & 26,81 & 36,73 \\
\hline $\begin{array}{c}\text { Custo Médio } \\
(\mathrm{R} \$ /-)\end{array}$ & 14,58 & 19,50 & 19,38 & 21,24 & 19,16 & 26,02 & 26,70 & 29,63 & 26,64 & 36,51 \\
\hline
\end{tabular}

Observações: 1) Preços válidos para o mês de março / 2007;
2) Pagamento com 28 ou 30 DDL;
3) Preços FOB Grande São Paulo;
4) Inclusos PIS, COFINS, ICMS e IPI;
5) Atendem às Normas ASTM A 249 ou ASTM A 269. 
A Tabela 23 apresenta os valores orçados por quatro fabricantes de tubos em aço carbono. Todos estes fabricantes utilizam lâminas de aço carbono fabricadas por usinas brasileiras. Todos os fabricantes informaram atender à Norma DIN 2458 /1626. Foi preservado também o nome dos fabricantes. Cabe salientar que os valores orçados pelo "fornecedor" representado pela letra "J", o foram feitos diretamente para a usina de açúcar parceira deste trabalho.

Tabela 23 - Preços para tubos em aço carbono com $2,65 \mathrm{~mm}$ de espessura para uso em evaporadores de usina de açúcar

\begin{tabular}{|c|c|c|}
\hline \multirow{2}{*}{ Fornecedor } & \multicolumn{2}{|c|}{ Custo Unitário } \\
\cline { 2 - 3 } & $\mathbf{R} \mathbf{\text { kg }}$ & $\mathbf{R} \mathbf{\$} / \mathbf{m}$ \\
\hline I & 2,92 & 6,75 \\
\hline E & 2,65 & 6,13 \\
\hline F & 3,90 & 9,05 \\
\hline J & 3,00 & 6,97 \\
\hline Preço Médio & $\mathbf{3 , 1 2}$ & $\mathbf{7 , 2 3}$ \\
\hline
\end{tabular}

Observações: 1) Preços válidos para o mês de março / 2007;

2) Pagamento com 28 ou 30 DDL;

3) Preços FOB Grande São Paulo;

4) Inclusos PIS, COFINS, ICMS e IPI;

5) Atendem à Norma DIN 2458 / 1626;

6) Aço carbono tipo SAE $1.008 / 12$.

A Tabela 24 reúne os preços médios para os diferentes tubos usados neste estudo, as suas quantidades e os custos de aquisição dos mesmos para a primeira compra, realizada em março de 2007. 
Tabela 24 - Valores pagos pela compra dos diferentes tipos de tubos para evaporadores de usinas de açúcar

\begin{tabular}{|c|c|c|c|}
\hline UNIDADES & $\begin{array}{c}\text { Quantidade } \\
\text { (t) }\end{array}$ & $\begin{array}{c}\text { Preço Médio } \\
(\mathrm{R} \$ / \mathrm{t})\end{array}$ & $\begin{array}{l}\text { Custo } \\
(\mathbf{R} \$)\end{array}$ \\
\hline Tubos Aço Carbono 2,65 mm & 101,6 & $3.120,00$ & $316.992,00$ \\
\hline Tubos Aço Inox 439, 1,50 mm & 54,1 & $14.580,00$ & $788.778,00$ \\
\hline Tubos Aço Inox 444, 1,20 mm & 43,8 & $19.380,00$ & $848.844,00$ \\
\hline Tubos Aço Inox 444, 1,50 mm & 55,0 & $19.160,00$ & $1.053 .800,00$ \\
\hline Tubos Aço Inox 304, 1,20 mm & 44,6 & $26.700,00$ & $1.190 .820,00$ \\
\hline Tubos Aço Inox 304, 1,50 mm & 56,1 & $26.640,00$ & $1.494 .504,00$ \\
\hline
\end{tabular}

Observação: Preços válidos para o mês de março/2007.

É importante realçar que devido a vida útil média dos tubos em aço carbono, após 6, 12, 18 e 24 anos serão compradas as mesmas quantidades de tubos, com os preços corrigidos pela inflação. Para as unidades compostas pelos tubos de aços inoxidáveis, tendo em vista a vida útil estimada de trinta anos, isto não acontecerá. A cada seis anos será considerado apenas a compra de $1 \%$ das suas respectivas quantidades, devido a falhas no madrilamento dos tubos.

\subsubsection{Transporte dos Tubos}

Para o transporte dos tubos foram utilizados os valores orçados pela empresa de transporte que atende a usina de açúcar parceira deste trabalho. A composição do custo do transporte para uma distância de 430 km em caminhão tipo "truck" com 14 t é a seguinte:

- Taxa de frete $R \$ 21,50$

- Taxa de coleta $R \$ 15,00$

- Despacho $R \$ 2,00$

- Taxa de frete por tonelada $R \$ 70,00$

- "Ad Valorem" $\mathrm{R} \$ 5,00$ por cada $\mathrm{R} \$ 1.000,00$ do valor da mercadoria (cobre o seguro da carga). 
Para exemplificar, será apresentado a seguir o cálculo do valor do frete por tonelada para os tubos de aço carbono.

- Taxa de frete. $R \$ 21,50$

- Taxa de coleta $R \$ 15,00$

- Despacho $R \$ 2,00$

- Taxa de frete por tonelada $R \$ 70,00 \times 14(t)=R \$ 980,00$

- Ad Valorem. $R \$ 5,00 \times R \$ 3.120,00 \times 14(t) / R \$ 1.000,00=$ $R \$ 218,40$

- $\quad$ Valor Total $(14 \mathrm{t})=\mathrm{R} \$ 1.236,90$

- $\quad$ Valor por tonelada $=\mathrm{R} \$ 88,35$

A Tabela 25 informa as quantidades dos diferentes tipos de tubos, os custos de frete e os valores totais para o transporte destes materiais em março de 2007.

Tabela 25 - Valores pagos pelo transporte dos diferentes tipos de tubos para evaporadores de usina de açúcar

\begin{tabular}{|c|c|c|c|}
\hline UNIDADES & $\begin{array}{c}\text { Quantidade } \\
\text { (t) }\end{array}$ & $\begin{array}{c}\text { Custo Frete } \\
\text { (R\$/t) }\end{array}$ & Transporte (R\$) \\
\hline Tubos Aço Carbono 2,65 mm & 101,6 & 88,35 & $8.976,00$ \\
\hline Tubos Aço Inox 439, 1,50 mm & 54,1 & 145,65 & $7.880,00$ \\
\hline Tubos Aço Inox 444, 1,20 mm & 43,8 & 169,55 & $7.426,00$ \\
\hline Tubos Aço Inox 444, 1,50 mm & 55,0 & 168,55 & $9.270,00$ \\
\hline Tubos Aço Inox 304, 1,20 mm & 44,6 & 206,25 & $9.199,00$ \\
\hline Tubos Aço Inox 304, 1,50 mm & 56,1 & 205,95 & $11.554,00$ \\
\hline
\end{tabular}

Observação: Preços válidos para o mês de março/2007.

Os custos dos fretes por tonelada para os tubos em aço inoxidável são maiores que para os tubos em aço carbono devido ao "ad valoren" pago pelo seguro da carga.

As despesas com transporte dos tubos acompanham a mesma periodicidade das compras dos mesmos, apresentadas no item 4.3.1, página 159. 


\subsubsection{Instalação e substituição dos tubos nos evaporadores}

A instalação dos tubos nos espelhos inferior e superior de um evaporador é composta por duas etapas, a colocação dos tubos nos furos correspondentes e o mandrilamento, enquanto que na substituição dos mesmos, deve ser acrescida a etapa de retirada dos tubos ou o que restou deles.

Para esta etapa partiu-se da uma experiência real da usina parceira. Para a substituição de nove mil seiscentos e cinqüenta e quatro tubos, vinte e sete funcionários gastaram quinze dias para a retirada, cinco para colocá-los e dez dias para mandrilá-los, trabalhando oito horas por dia, ao preço de $\mathrm{R} \$ 17,84$ a hora. Este custo total corresponde ao valor pago aos funcionários, mais alimentação e despesas trabalhistas, em março de 2007.

A partir destas informações e considerando as quantidades de tubos utilizadas pelas diferentes unidades em estudo, foram calculados os custos para a instalação e a substituição destes tubos. Estas informações são apresentadas na Tabela 26.

Tabela 26 - Custo da instalação e da substituição de tubos em um evaporador de usina de açúcar

\begin{tabular}{|l|c|c|c|}
\hline \multicolumn{1}{|c|}{ UNIDADES } & Quantidade Tubos & Instalação (R\$) & $\begin{array}{c}\text { Substituição } \\
\text { (R\$) }\end{array}$ \\
\hline Tubos Aço Carbono 2,65 mm & 12.947 & $77.518,00$ & $155.036,00$ \\
\hline Tubos Aço Inox 1,50 mm & 12.091 & $72.393,00$ & $144.785,00$ \\
\hline Tubos Aço Inox 1,20 mm & 11.885 & $71.159,00$ & $142.319,00$ \\
\hline
\end{tabular}

Observação: Preços válidos para o mês de março/2007.

Os gastos com a substituição dos tubos se repetem com a mesma freqüência com que eles são comprados. 


\subsubsection{Limpeza dos tubos}

De forma semelhante ao item 4.3.3, para a execução desta etapa foram utilizados dados reais da usina parceira. Para a limpeza mecânica de um sistema de evaporação constituído por um pré-evaporador com nove mil tubos e mais quatro efeitos com dois mil trezentos e setenta e sete tubos cada, são utilizados vinte e dois funcionários trabalhando quatro horas, consumindo cento e vinte mil litros de água e um total de $155 \mathrm{kWh}$ de energia elétrica. O tempo total gasto para esta operação, da parada do sistema de evaporação até o retorno a operação é de sete horas. O custo da mão-de-obra é o mesmo informado no item anterior, $R \$ 17,84$ /hora e os preços de cada mil litros de água e da energia elétrica são $R \$ 0,13$ e $R \$ 0,25$, respectivamente.

Como analisado no item 2.7, página 106, os tubos em aços inoxidáveis incrustam-se menos devido ao seu maior polimento. Tem-se observado em usinas que possuem evaporadores construídos com tubos em aço inoxidável e aço carbono, que estes incrustam-se 50\% a mais, aproximadamente. Ou seja, se um evaporador com tubos em aço carbono precisa ser limpo a cada dez dias, em aço inoxidável esta parada poderia acontecer, em média, a cada quinze dias.

Como o período anual efetivo de safra foi estimado em duzentos e dez dias, tem-se então vinte e uma paradas para os evaporadores com tubos em aço carbono e quatorze paradas quando os tubos são em aço inoxidável.

Com os dados apresentados, o custo da limpeza mecânica na usina parceira por parada, é:

- Número de tubos: $9.000+4 \times 2.377=18.508$ tubos;

- Mão de obra: 22 funcionários $x 4$ horas $x \mathrm{R} \$ 17,84 /$ hora $=R \$ 1.570,00$

- Água: $120.000 \mathrm{~L} \times \mathrm{R} \$ 0,13 / 1.000 \mathrm{~L}=\mathrm{R} \$ 15,60$

- Energia elétrica: $155 \mathrm{kWh} \times 4 \mathrm{~h} \times \mathrm{R} \$ 0,25 / \mathrm{kWh}=\mathrm{R} \$ 155,00$

- Custo total por parada: $\mathrm{R} \$ 1.740,60$ (para a limpeza de 18.508 tubos).

Para este estudo de CCV, em função do tipo de aço e espessura de parede dos tubos, tem-se diferentes números de tubos (ver Tabela 11, página 124). Desta forma, o custo por parada, em março de 2007 era: 
- Tubos aço carbono 2,65 mm: $12.947 / 18.508 \times \mathrm{R} \$ 1.740,60=\mathrm{R} \$ 1.218,00$;

- Tubos aço inoxidável 1,50 mm: 12.091/18.508 x R $\$ 1.740,60=R \$ 1.137,00$;

- Tubos aço inoxidável 1,20 mm: 11.845/18.508 x R $\$ 1.740,60=R \$ 1.114,00$.

O custo de limpeza será considerado por safra, durante trinta anos consecutivos.

\subsubsection{Venda da Sucata}

Em um estudo de CCV, além do levantamento de todas as despesas ocorridas no período do trabalho, é necessário considerar também os possíveis créditos obtidos pela venda dos materiais utilizados, após a sua vida útil. Desta forma, como neste trabalho foi considerada a substituição total dos tubos em aço carbono a cada seis anos, após 6, 12, 18, 24 e 30 anos, far-se-á a venda desta sucata. Devido à falta de dados representativos serão consideradas, a cada substituição, as mesmas 101,6 t.

Para os tubos em aços inoxidáveis, como foi considerada uma vida útil de 30 anos, a venda da sucata acontecerá após este período de tempo. A cada seis anos acontecerá a venda de apenas $1 \%$ da quantidade utilizada, tendo em vista a pequena reposição.

Para os preços das sucatas, foram utilizados os praticados pela empresa Cake Work Aço Inoxidável Ltda, instalada em Indaiatuba/SP. Os valores pagos pela Cake Work em março de 2007 eram:

- Sucata ferrosa: $R \$ 0,30-0,40 / \mathrm{kg}$ (o preço é variável em função do estado em que esta sucata se apresenta). Foi usado o valor $R \$ 0,35 / \mathrm{kg}$;

- Sucata aços ferríticos/martensíticos (410, 420, 430, 439, etc.): $R \$ 0,80 / \mathrm{kg}$;

- Sucata aços austeníticos (304, 316, etc.): $R \$ 7,10 / \mathrm{kg}$

O preço da sucata de aço 444 , mesmo contendo $2 \%$ de molibdênio, é prejudicado pela sua pequena disponibilidade e é pago como ferrítico comum, representado na sua maioria pelos aços 410 e 430 (informações pessoais) ${ }^{4}$. 
A sucata austenítica está muito valorizada devido ao alto valor do níquel, sendo hoje uma "commodity", cotada no mercado internacional. No dia 08.05.2007 ela era comprada por $\mathrm{R} \$ 7,80 / \mathrm{kg}$.

\footnotetext{
${ }^{4}$ Informações pessoais da Gerência da Cake Work Aço Inoxidável Ltda, em 16.03.2007.
} 


\subsection{ATUALIZAÇÃO FINANCEIRA E COMPOSIÇÃO DOS CUSTOS TOTAIS}

Como os custos informados em 4.3, página 158, acontecem ao longo de trinta anos, eles precisam ser corrigidos pela inflação. Estas análises devem comparar cenários homogêneos e, sendo assim, é necessário trazer todos os gastos ao valor presente. Isto é feito utilizando-se a taxa nominal de juros, ao invés da inflação, porque neste caso, assume-se que um montante não gasto num determinado momento, poderia ser aplicado no mercado financeiro.

Em março de 2007, o Instituto de Pesquisa Econômica Aplicada (Ipea) revisou a previsão de inflação para 2007, medida pelo Índice de Preços ao Consumidor Amplo (IPCA). Em seu boletim conjuntural de março, a estimativa de variação deste índice, utilizado para balizar as metas de inflação do governo, passou de $4,3 \%$ para $3,8 \%$.

A taxa nominal de juros, a Selic, estabelecida pelo Comitê de Política Monetária (Copom), do Banco Central, também foi alterada para baixo, de 12\% para $11,5 \%$ anuais, na média do último trimestre de $2007 .{ }^{5}$

A Tabela 27 apresenta os "Fatores de Juros do Valor Futuro - FJVF" calculados através da expressão $F J V F_{i, n}=(1+i)^{n}$, onde "i" é a inflação, igual a 3,8\% e "n" o número de anos considerado; e os "Fatores de Juros do Valor Presente FJVP", calculados através da fórmula $F J V P_{i, n}=1 /(1+i)^{n}$, onde "i", neste caso, é a taxa nominal de juros, igual a $11,5 \%$ e "n" o número de anos considerado.

\footnotetext{
${ }^{5}$ Ipea projeta IPCA e taxa Selic menores em 2007 - 07/03/2007 - Valor Online. Disponível em: http://noticias.uol.com.br/economia/ultnot/valor/2007/03/07/ult1913u65684.jhtm?action
} 
Tabela 27 - Valores calculados para os "Fatores de Juros do Valor Futuro - FJVF" e "Fatores e Juros do Valor Presente - FJVP"

\begin{tabular}{|c|c|c|}
\hline$n$ & FJVF & FJVP \\
\hline 1 & 1,038 & 0,897 \\
\hline 2 & 1,077 & 0,804 \\
\hline 3 & 1,118 & 0,721 \\
\hline 4 & 1,161 & 0,647 \\
\hline 5 & 1,205 & 0,580 \\
\hline 6 & 1,251 & 0,520 \\
\hline 7 & 1,298 & 0,467 \\
\hline 8 & 1,348 & 0,419 \\
\hline 9 & 1,399 & 0,375 \\
\hline 10 & 1,452 & 0,337 \\
\hline 11 & 1,507 & 0,302 \\
\hline 12 & 1,565 & 0,271 \\
\hline 13 & 1,624 & 0,243 \\
\hline 14 & 1,686 & 0,218 \\
\hline 15 & 1,750 & 0,195 \\
\hline 16 & 1,816 & 0,175 \\
\hline 17 & 1,885 & 0,157 \\
\hline 18 & 1,957 & 0,141 \\
\hline 19 & 2,031 & 0,126 \\
\hline 20 & 2,108 & 0,113 \\
\hline 21 & 2,189 & 0,102 \\
\hline 22 & 2,272 & 0,091 \\
\hline 23 & 2,358 & 0,082 \\
\hline 24 & 2,448 & 0,073 \\
\hline 25 & 2,541 & 0,065 \\
\hline 26 & 2,637 & 0,059 \\
\hline 27 & 2,737 & 0,053 \\
\hline 28 & 2,841 & 0,048 \\
\hline 29 & 2,949 & 0,043 \\
\hline 30 & 3,061 & 0,038 \\
\hline
\end{tabular}

Observações: $\mathrm{n}=$ ano do estudo;

$\mathrm{i}$ = inflação medida pelo IPCA, igual a 3,8 \% ao ano;

Taxa nominal de juros - Selic, igual a $11,5 \%$ ao ano;

FJVF: Fator de Juro do Valor futuro $=(1+0,038)^{\text {n }}$

FJVP: Fator de Juro do Valor Presente $=1 /(1+0,115)^{\mathrm{n}}$

Os "FJVF" e "FJVP" podem também ser obtidos em tabelas ${ }^{37}$, por intermédio de calculadoras financeiras ou planilhas Excell.

De posse destes "fatores de juros", todos os componentes de custo deste trabalho foram corrigidos financeiramente e, posteriormente, foram trazidos ao valor presente, de acordo com as taxas de oportunidade explicadas anteriormente, de 
forma a poder avaliar qual ou quais unidades em estudo são mais vantajosas financeiramente.

\subsubsection{Compra dos Tubos}

A Tabela 28 apresenta os dados relativos às compras dos diferentes tubos que compõem as unidades deste estudo de CCV. Ela utiliza os preços médios para cada tipo de tubo informados na Tabela 24, página 162, que passam a ser os preços pagos no tempo "zero" deste estudo. Para as compras a serem efetuadas nos anos $6,12,18$ e 24 anos do ciclo de vida deste trabalho, estes preços foram corrigidos pelos FJVFs correspondentes, apresentados na Tabela 27, página 169. O somatório destes valores pagos compôs o custo contábil relativo ao componente de custo em análise. O cálculo do valor presente seguiu raciocínio semelhante, usando os respectivos FJVPs, também apresentados na Tabela 27, página 169.

Como pode ser observado, mesmo com o baixo custo inicial do tubo em aço carbono, no final do período de estudo, 30 anos, o valor desta unidade foi $60 \%$ maior que o custo contábil da unidade tubo em aço inoxidável 304 com 1,50 mm de espessura, a segunda unidade em valor neste componente de custo. Contribuíram para isso a alta freqüência de reposição e a inflação de 3,8\%.

Independente deste quadro, quando se considera o custo do dinheiro no tempo, deve-se calcular o valor presente (VP) para o momento de desembolso, já que este é o valor financeiro que realmente norteia a decisão por um dado investimento. Neste caso, apenas a unidade tubos em aço 439 apresenta um valor semelhante à unidade tubos em aço carbono. Para todas as demais unidades constituídas por tubos em aços inoxidáveis, os VP são maiores que o correspondente aos tubos em aço carbono. 
Tabela 28 - Custos contábeis e valores presentes relativos à compra dos tubos para evaporadores de usinas de açúcar

\begin{tabular}{|c|c|c|c|c|c|c|c|}
\hline \multirow{2}{*}{$\begin{array}{c}\text { VALOR } \\
\text { PRESENTE } \\
\text { (R\$) }\end{array}$} & \multicolumn{6}{|c|}{ ANO DO CICLO DE VIDA } & \multirow{2}{*}{$\begin{array}{c}\text { CUSTOS } \\
\text { CONTÁBEIS } \\
\text { (R\$) }\end{array}$} \\
\hline & 0 & 6 & 12 & 18 & 24 & 30 & \\
\hline \multicolumn{8}{|c|}{ AÇO CARBONO COM 2,65 mm ESPESSURA / QUANTIDADES (t) / CUSTO (R\$) } \\
\hline- & 101,6 & 101,6 & 101,6 & 101,6 & 101,6 & - & - \\
\hline- & $316.992,00$ & $396.557,00$ & $496.093,00$ & $620.353,00$ & $775.996,00$ & - & $2.605 .991,00$ \\
\hline $801.761,00$ & $316.992,00$ & $206.210,00$ & $134.441,00$ & $87.470,00$ & $56.648,00$ & - & - \\
\hline \multicolumn{8}{|c|}{ AÇO INOX 439 COM 1,50 mm ESPESSURA / QUANTIDADES (t) / CUSTO (R\$) } \\
\hline- & 54,1 & 0,541 & 0,541 & 0,541 & 0,541 & - & - \\
\hline- & $788.778,00$ & $9.868,00$ & $12.344,00$ & $15.436,00$ & $19.309,00$ & - & $845.735,00$ \\
\hline $800.841,00$ & $788.778,00$ & $5.131,00$ & $3.345,00$ & $2.177,00$ & $1.410,00$ & - & - \\
\hline \multicolumn{8}{|c|}{ AÇO INOX 444 COM 1,20 mm ESPESSURA / QUANTIDADES (t) / CUSTO (R\$) } \\
\hline- & 43,8 & 0,438 & 0,438 & 0,438 & 0,438 & - & - \\
\hline- & $848.844,00$ & $10.619,00$ & $13.284,00$ & $16.619,00$ & $20.790,00$ & - & $910.156,00$ \\
\hline $861.827,00$ & $848.844,00$ & $5.522,00$ & $3.600,00$ & $2.348,00$ & $1.518,00$ & - & - \\
\hline \multicolumn{8}{|c|}{ AÇO INOX 444 COM 1,50 mm ESPESSURA / QUANTIDADES (t) / CUSTO (R\$) } \\
\hline- & 55,0 & 0,55 & 0,55 & 0,55 & 0,55 & - & - \\
\hline- & $1.053 .800,00$ & $13.183,00$ & $16.492,00$ & $20.623,00$ & $25.797,00$ & - & $1.129 .895,00$ \\
\hline 1.069.915,00 & $1.053 .800,00$ & $6.855,00$ & $4.469,00$ & $2.908,00$ & $1.883,00$ & - & - \\
\hline \multicolumn{8}{|c|}{ AÇO INOX 304 COM 1,20 mm ESPESSURA / QUANTIDADES (t) / CUSTO (R\$) } \\
\hline- & 44,6 & 0,446 & 0,446 & 0,446 & 0,446 & - & - \\
\hline- & $1.190 .820,00$ & $14.897,00$ & $18.636,00$ & $23.304,00$ & $29.151,00$ & - & $1.276 .808,00$ \\
\hline $1.209 .032,00$ & $1.190 .820,00$ & $7.747,00$ & $5.051,00$ & $3.286,00$ & $2.128,00$ & - & - \\
\hline \multicolumn{8}{|c|}{ AÇO INOX 304 COM 1,50 mm ESPESSURA / QUANTIDADES (t) / CUSTO (R\$) } \\
\hline- & 56,1 & 0,561 & 0,561 & 0,561 & 0,561 & - & - \\
\hline- & $1.494 .504,00$ & $18.696,00$ & $23.389,00$ & $29.247,00$ & $36.586,00$ & - & $1.602 .422,00$ \\
\hline $1.517 .359,00$ & $1.494 .504,00$ & $9.722,00$ & $6.338,00$ & $4.124,00$ & $2.671,00$ & - & - \\
\hline
\end{tabular}

Observações: Inflação medida pelo IPCA e igual a 3,8\% ao ano.

Taxa nominal de juros - Selic, igual a $11,5 \%$ ao ano.

FJVF e FJVP extraídos da Tabela 27, página 169. 


\subsubsection{Transporte dos tubos}

O componente de custo transporte dos tubos será o segundo a ser estudado, por estar diretamente ligado à compra dos tubos, tanto em termos de freqüência de desembolsos quanto a sua periodicidade.

A Tabela 29 apresenta os dados relativos a esta etapa deste inventário.

Para este componente de custo já se observa a influência negativa que uma alta freqüência de substituições pode ocasionar, tanto contábil quanto financeiramente, a um sistema em uma avaliação de longo prazo, ou seja, a unidade tubos em aço carbono termina os trinta anos de avaliação em desvantagem com relação a todas unidades relativas aos tubos em aços inoxidáveis. 
Tabela 29 - Custos contábeis e valores presentes relativos ao transporte dos tubos para evaporadores de usinas de açúcar

\begin{tabular}{|c|c|c|c|c|c|c|c|}
\hline \multirow{2}{*}{$\begin{array}{c}\text { VALOR } \\
\text { PRESENTE } \\
\text { (R\$) }\end{array}$} & \multicolumn{6}{|c|}{ ANO DO CICLO DE VIDA } & \multirow{2}{*}{$\begin{array}{c}\text { CUSTOS } \\
\text { CONTÁBEIS } \\
(\mathrm{R} \$)\end{array}$} \\
\hline & 0 & 6 & 12 & 18 & 24 & 30 & \\
\hline \multicolumn{8}{|c|}{ AÇO CARBONO COM 2,65 mm ESPESSURA / QUANTIDADES (t) CUSTO (R\$) } \\
\hline- & 101,6 & 101,6 & 101,6 & 101,6 & 101,6 & - & - \\
\hline- & $8.976,00$ & $11.229,00$ & $14.048,00$ & $17.566,00$ & $21.973,00$ & - & $73.792,00$ \\
\hline $22.703,00$ & $8.976,00$ & $5.839,00$ & $3.807,00$ & $2.477,00$ & $1.604,00$ & - & - \\
\hline \multicolumn{8}{|c|}{ AÇO INOX 439 COM 1,50 mm ESPESSURA / QUANTIDADES (t) CUSTO (R\$) } \\
\hline- & 54,1 & 0,541 & 0,541 & 0,541 & 0,541 & - & - \\
\hline- & $7.880,00$ & 99,00 & 123,00 & 154,00 & 193,00 & - & $8.449,00$ \\
\hline $8.000,00$ & $7.880,00$ & 51,00 & 33,00 & 22,00 & 14,00 & - & - \\
\hline \multicolumn{8}{|c|}{ AÇO INOX 444 COM 1,20 mm ESPESSURA / QUANTIDADES (t) CUSTO (R\$) } \\
\hline- & 43,8 & 0,438 & 0,438 & 0,438 & 0,438 & - & - \\
\hline- & $7.426,00$ & 93,00 & 116,00 & 145,00 & 182,00 & - & $7.962,00$ \\
\hline $7.540,00$ & $7.426,00$ & 48,00 & 32,00 & 21,00 & 13,00 & - & - \\
\hline \multicolumn{8}{|c|}{ AÇO INOX 444 COM 1,50 mm ESPESSURA I QUANTIDADES (t) CUSTO (R\$) } \\
\hline- & 55,0 & 0,55 & 0,55 & 0,55 & 0,55 & - & - \\
\hline- & $9.270,00$ & 116,00 & 145,00 & 181,00 & 227,00 & - & $9.939,00$ \\
\hline $9.412,00$ & $9.270,00$ & 60,00 & 39,00 & 26,00 & 17,00 & - & - \\
\hline \multicolumn{8}{|c|}{ AÇO INOX 304 COM 1,20 mm ESPESSURA / QUANTIDADES (t) CUSTO (R\$) } \\
\hline- & 44,6 & 0,446 & 0,446 & 0,446 & 0,446 & - & - \\
\hline- & $9.199,00$ & 115,00 & 144,00 & 180,00 & 225,00 & - & $9.863,00$ \\
\hline $9.339,00$ & $9.199,00$ & 60,00 & 39,00 & 25,00 & 16,00 & - & - \\
\hline \multicolumn{8}{|c|}{ AÇO INOX 304 COM 1,50 mm ESPESSURA / QUANTIDADES (t) CUSTO (R\$) } \\
\hline- & 56,1 & 0,561 & 0,561 & 0,561 & 0,561 & - & - \\
\hline- & $11.554,00$ & 145,00 & 181,00 & 226,00 & 283,00 & - & $12.389,00$ \\
\hline $11.731,00$ & $11.554,00$ & 75,00 & 49,00 & 32,00 & 21,00 & - & - \\
\hline
\end{tabular}

Observações: Inflação medida pelo IPCA e igual a 3,8\% ao ano.

Taxa nominal de juros - Selic, igual a $11,5 \%$ ao ano

FJVF e FJVP extraídos da Tabela 27, página 169. 


\subsubsection{Instalação e reposição dos tubos}

A Tabela 26, página 164, apresentou os custos para instalação e reposição dos tubos no tempo zero deste estudo, para as três espessuras de tubos em avaliação.

A Tabela 30 apresentou os dados econômicos e financeiros relativos a este importante componente de custo. A alta freqüência de substituição dos tubos em aço carbono levou a uma despesa total quase cinco vezes maior que a que acontece com os tubos em aços inoxidáveis, sendo que o VP relativo aos tubos em aço carbono é quatro vezes maior que os demais. 
Tabela 30 - Custos contábeis e valores presentes relativos à instalação e substituição dos tubos para evaporadores de usinas de açúcar

\begin{tabular}{|c|c|c|c|c|c|c|c|}
\hline \multirow{2}{*}{$\begin{array}{c}\text { VALOR } \\
\text { PRESENTE } \\
\text { (R\$) }\end{array}$} & \multicolumn{6}{|c|}{ ANO DO CICLO DE VIDA } & \multirow{2}{*}{$\begin{array}{c}\text { CUSTOS } \\
\text { CONTÁBEIS } \\
(\mathrm{R} \$)\end{array}$} \\
\hline & 0 & 6 & 12 & 18 & 24 & 30 & \\
\hline- & 12.947 & 12.947 & 12.947 & 12.947 & 12.947 & 12.947 & - \\
\hline- & $77.518,00$ & $193.950,00$ & $242.631,00$ & $303.406,00$ & $379.528,00$ & $237.283,00$ & $1.434 .316,00$ \\
\hline $323.628,00$ & $77.518,00$ & $100.854,00$ & $65.753,00$ & $42.780,00$ & $27.706,00$ & $9.017,00$ & - \\
\hline \multicolumn{8}{|c|}{ AÇO INOXIDÁVEL COM 1,50 mm ESPESSURA / QUANTIDADES (tubos) CUSTO (R\$) } \\
\hline- & 12.091 & 121 & 121 & 121 & 121 & 12.091 & - \\
\hline- & $72.393,00$ & $1.812,00$ & $2.266,00$ & $2.834,00$ & $3.545,00$ & $221.595,00$ & $304.445,00$ \\
\hline $83.029,00$ & $72.393,00$ & 942,00 & 614,00 & 400,00 & 259,00 & $8.421,00$ & - \\
\hline \multicolumn{8}{|c|}{ AÇO INOXIDÁVEL COM 1,20 mm ESPESSURA / QUANTIDADES (tubos) CUSTO (R\$) } \\
\hline- & 11.885 & 119 & 119 & 119 & 119 & 119 & - \\
\hline $81.613,00$ & $71.159,00$ & 926,00 & 604,00 & 393,00 & 254,00 & $8.277,00$ & - \\
\hline
\end{tabular}

Observações: Inflação medida pelo IPCA e igual a 3,8\% ao ano.

Taxa nominal de juros - Selic, igual a $11,5 \%$ ao ano

FJVF e FJVP extraídos da Tabela 27, página 169 


\subsubsection{Limpeza dos tubos}

A Tabela 31 relaciona as despesas com limpeza mecânica dos tubos. São apresentadas colunas com os preços corrigidos pela inflação de $3,8 \%$ ao ano e os valores presentes respectivos, para os quais foi usada a taxa de juros de $11,5 \%$ ao ano, para os aços com 2,65, 1,50 e 1,20 mm de espessuras. Nesta Tabela o ano "n" igual a zero corresponde ao valor para este componente de custo em março de 2007. Os valores de FJVF e FJVP foram extraídos da Tabela 27, página 169.

Tabela 31 - Despesas com a Limpeza dos Tubos ao longo do estudo de CCV

\begin{tabular}{|c|c|c|c|c|c|c|}
\hline \multicolumn{7}{|c|}{ DESPESAS COM A LIMPEZA MECÂNICA DOS TUBOS - R\$ } \\
\hline \multirow[b]{2}{*}{$\mathbf{n}$} & \multicolumn{2}{|c|}{ Tubos Aço Carbono 2,65mm } & \multicolumn{2}{|c|}{ Tubos Aço Inoxidável $1,50 \mathrm{~mm}$} & \multicolumn{2}{|c|}{ Tubos Aço Inoxidável $1,20 \mathrm{~mm}$} \\
\hline & $\begin{array}{c}\text { Custo } \\
\text { Contábil }\end{array}$ & $\begin{array}{c}\text { Valor } \\
\text { Presente } \\
\end{array}$ & Custo Contábil & $\begin{array}{c}\text { Valor } \\
\text { Presente } \\
\end{array}$ & Custo Contábil & $\begin{array}{c}\text { Valor } \\
\text { Presente } \\
\end{array}$ \\
\hline 0 & $25.578,00$ & $25.578,00$ & $15.918,00$ & $15.918,00$ & $15.596,00$ & $15.596,00$ \\
\hline 1 & $26.550,00$ & $23.815,00$ & $16.523,00$ & $14.821,00$ & $16.187,00$ & $14.521,00$ \\
\hline 2 & $27.548,00$ & $22.148,00$ & $17.144,00$ & $13.784,00$ & $16.797,00$ & $13.505,00$ \\
\hline 3 & $28.596,00$ & $20.618,00$ & $17.796,00$ & $12.831,00$ & $17.436,00$ & $12.572,00$ \\
\hline 4 & $29.696,00$ & $19.213,00$ & $18.481,00$ & $11.957,00$ & $18.107,00$ & $11.715,00$ \\
\hline 5 & $30.822,00$ & $17.877,00$ & $19.181,00$ & $11.125,00$ & $18.793,00$ & $10.900,00$ \\
\hline 6 & $31.998,00$ & $16.639,00$ & $19.913,00$ & $10.355,00$ & $19.511,00$ & $10.146,00$ \\
\hline 7 & $33.200,00$ & $15.505,00$ & $20.662,00$ & $9.649,00$ & $20.244,00$ & $9.454,00$ \\
\hline 8 & $34.479,00$ & $14.447,00$ & $21.458,00$ & $8.991,00$ & $21.023,00$ & $8.809,00$ \\
\hline 9 & $35.784,00$ & $13.419,00$ & $22.269,00$ & $8.351,00$ & $21.819,00$ & $8.182,00$ \\
\hline 10 & $37.139,00$ & $12.516,00$ & $23.113,00$ & $7.789,00$ & $22.645,00$ & $7.632,00$ \\
\hline 11 & $38.546,00$ & $11.641,00$ & $23.988,00$ & $7.245,00$ & $23.503,00$ & $7.098,00$ \\
\hline 12 & $40.030,00$ & $10.848,00$ & $24.912,00$ & $6.751,00$ & $24.408,00$ & $6.615,00$ \\
\hline 13 & $41.539,00$ & $10.094,00$ & $25.851,00$ & $6.282,00$ & $25.328,00$ & $6.155,00$ \\
\hline 14 & $43.125,00$ & $9.218,00$ & $26.838,00$ & $5.851,00$ & $26.295,00$ & $5.732,00$ \\
\hline 15 & $44.762,00$ & $8.729,00$ & $27.857,00$ & $5.432,00$ & $27.293,00$ & $5.322,00$ \\
\hline 16 & $46.450,00$ & $8.129,00$ & $28.907,00$ & $5.059,00$ & $28.322,00$ & $4.957,00$ \\
\hline 17 & $48.215,00$ & $7.570,00$ & $30.005,00$ & $4.711,00$ & $29.399,00$ & $4.616,00$ \\
\hline 18 & $50.056,00$ & $7.058,00$ & $31.152,00$ & $4.392,00$ & $30.521,00$ & $4.304,00$ \\
\hline 19 & $51.949,00$ & $6.546,00$ & $32.330,00$ & $4.074,00$ & $31.676,00$ & $3.991,00$ \\
\hline 20 & $53.918,00$ & $6.093,00$ & $33.555,00$ & $3.792,00$ & $32.876,00$ & $3.715,00$ \\
\hline 21 & $55.990,00$ & $5.711,00$ & $34.845,00$ & $3.554,00$ & $34.140,00$ & $3.482,00$ \\
\hline 22 & $58.113,00$ & $5.288,00$ & $36.166,00$ & $3.291,00$ & $35.434,00$ & $3.225,00$ \\
\hline 23 & $60.313,00$ & $4.946,00$ & $37.535,00$ & $3.078,00$ & $36.775,00$ & $3.016,00$ \\
\hline 24 & $62.615,00$ & $4.571,00$ & $38.967,00$ & $2.845,00$ & $38.179,00$ & $2.787,00$ \\
\hline 25 & $64.994,00$ & $4.225,00$ & $40.448,00$ & $2.629,00$ & $39.629,00$ & $2.576,00$ \\
\hline 26 & $67.449,00$ & $3.980,00$ & $41.976,00$ & $2.477,00$ & $41.127,00$ & $2.427,00$ \\
\hline 27 & $70.007,00$ & $3.710,00$ & $43.568,00$ & $2.309,00$ & $42.686,00$ & $2.262,00$ \\
\hline 28 & $72.667,00$ & $3.488,00$ & $45.223,00$ & $2.171,00$ & $44.308,00$ & $2.127,00$ \\
\hline 29 & $75.430,00$ & $3.244,00$ & $46.942,00$ & $2.019,00$ & $45.993,00$ & $1.978,00$ \\
\hline 30 & $78.284,00$ & $2.975,00$ & $48.725,00$ & $1.852,00$ & $47.739,00$ & $1.814,00$ \\
\hline$\Sigma$ & $1.465 .842,00$ & $329.839,00$ & $912.248,00$ & $205.385,00$ & $893.789,00$ & $201.231,00$ \\
\hline
\end{tabular}


Na última linha da Tabela 31 são informados os somatórios para os custos contábeis e valores presentes de cada coluna.

A Tabela 31 mostra que os custos contábeis relativos à limpeza dos tubos em aço carbono e os respectivos valores presentes são mais que $60 \%$ que os valores correspondentes às unidades tubos em aços inoxidáveis.

\subsubsection{Venda da sucata}

A Tabela 32 mostra a atualização financeira para este componente de custo. Nele, as sucatas dos diferentes aços começam a ser vendidas a partir do sexto ano, até o trigésimo ano, com intervalos de seis em seis.

Como a venda das sucatas dos diferentes aços inoxidáveis está concentrada no trigésimo ano, em função da sua alta durabilidade, quando se traz as receitas auferidas para o valor presente, os resultados benéficos deste crédito são pequenos, mesmo para a sucata do aço 304, uma sucata com alto valor de venda agregado.

Como a venda de sucata gera crédito para as diferentes unidades em estudo, os seus respectivos valores serão somados quando for feito o fluxo de caixa para as diferentes unidades. 
Tabela 32 - Custos contábeis e valores presentes relativos à venda das sucatas dos tubos para evaporadores de usinas de açúcar

\begin{tabular}{|c|c|c|c|c|c|c|c|}
\hline \multirow{2}{*}{$\begin{array}{c}\text { VALOR } \\
\text { PRESENTE } \\
\text { (R\$) }\end{array}$} & \multicolumn{6}{|c|}{ ANO DO CICLO DE VIDA } & \multirow{2}{*}{$\begin{array}{c}\text { CUSTOS } \\
\text { CONTÁBEIS } \\
(\mathrm{R} \$)\end{array}$} \\
\hline & 0 & 6 & 12 & 18 & 24 & 30 & \\
\hline \multicolumn{8}{|c|}{ AÇO CARBONO COM 2,65 mm ESPESSURA I QUANTIDADES (t) CUSTO (R\$) } \\
\hline- & - & 101,6 & 101,6 & 101,6 & 101,6 & 101,6 & - \\
\hline- & - & $44.486,00$ & $55.651,00$ & $69.591,00$ & $87.051,00$ & $108.849,00$ & $365.628,00$ \\
\hline $58.518,00$ & - & $23.133,00$ & $15.082,00$ & $9.812,00$ & $6.355,00$ & $4.136,00$ & - \\
\hline \multicolumn{8}{|c|}{ AÇO INOX 439 COM 1,50 mm ESPESSURA / QUANTIDADES (t) CUSTO (R\$) } \\
\hline- & - & 0,541 & 0,541 & 0,541 & 0,541 & 54,1 & - \\
\hline- & - & 541,00 & 677,00 & 847,00 & $1.060,00$ & $132.480,00$ & $135.605,00$ \\
\hline $5.696,00$ & - & 282,00 & 184,00 & 119,00 & 77,00 & $5.034,00$ & - \\
\hline \multicolumn{8}{|c|}{ AÇO INOX 444 COM 1,20 mm ESPESSURA / QUANTIDADES (t) CUSTO (R\$) } \\
\hline- & - & 0,438 & 0,438 & 0,438 & 0,438 & 43,8 & - \\
\hline- & - & 438,00 & 548,00 & 686,00 & 858,00 & $107.257,00$ & $109.787,00$ \\
\hline $4.613,00$ & - & 228,00 & 149,00 & 97,00 & 63,00 & $4.076,00$ & - \\
\hline \multicolumn{8}{|c|}{ AÇO INOX 444 COM 1,50 mm ESPESSURA / QUANTIDADES (t) CUSTO (R\$) } \\
\hline- & - & 550,00 & 687,00 & 861,00 & 1077,00 & $134.684,00$ & $137.859,00$ \\
\hline $5.791,00$ & - & 286,00 & 187,00 & 121,00 & 79,00 & $5.118,00$ & - \\
\hline \multicolumn{8}{|c|}{ AÇO INOX 304 COM 1,20 mm ESPESSURA / QUANTIDADES (t) CUSTO (R\$) } \\
\hline- & - & 0,446 & 0,446 & 0,446 & 0,446 & 44,6 & - \\
\hline- & - & $3.961,00$ & $4.956,00$ & $6.197,00$ & $7.752,00$ & $969.296,00$ & $992.162,00$ \\
\hline $41.676,00$ & - & $2.060,00$ & $1.343,00$ & 874,00 & 566,00 & $36.833,00$ & - \\
\hline \multicolumn{8}{|c|}{ AÇO INOX 304 COM 1,50 mm ESPESSURA / QUANTIDADES (t) CUSTO (R\$) } \\
\hline- & - & 0,561 & 0,561 & 0,561 & 0,561 & 56,1 & - \\
\hline- & - & $4.983,00$ & $6.234,00$ & $7.795,00$ & $9.751,00$ & $1.219 .227,00$ & $1.247 .990,00$ \\
\hline $52.422,00$ & - & $2.595,00$ & $1.689,00$ & $1.099,00$ & 712,00 & $46.331,00$ & - \\
\hline
\end{tabular}

Observações: Inflação medida pelo IPCA e igual a 3,8\% ao ano.

Taxa nominal de juros - Selic, igual a $11,5 \%$ ao ano.

FJVF e FJVP extraídos da Tabela 27, página 169 


\subsection{DISCUSSÃO}

\subsubsection{Custos Contábeis}

A Tabela 33 relaciona os custos contábeis para os diferentes componentes de custo relativos às unidades ao longo deste estudo de CCV. Ou seja, estão relacionados o que um usineiro desembolsaria por cada um dos tipos de tubos em avaliação, na compra, transporte, instalação/substituição, limpeza e receberia pela venda da sucata, durante o ciclo de vida deste estudo, trinta anos. Esta Tabela adota o conceito de fluxo de caixa, ou seja, os desembolsos representam um valor negativo, e devido a isto, estão entre parênteses. As receitas, como as auferidas com a venda das sucatas, correspondem a crédito, ou seja, valores com sinal positivo.

Os dados apresentados nesta Tabela podem causar espanto aos profissionais e empresários que não estão acostumados a utilizar o CCV como ferramenta gerencial nas suas empresas; bem como discordância em outros pelos valores apresentados. Para aqueles que fazem parte deste segundo grupo, é útil salientar que os preços de compra dos tubos, transporte e venda de sucata foram os de mercado e os valores apresentados nas colunas Instalação/Substituição e Limpeza dos Tubos foram obtidos da rotina de usina de açúcar de grande porte, que apresenta um nível técnico e tecnológico muito bom. As principais constatações foram:

- Na compra dos tubos em aço carbono, um produto tido como de baixo custo, devido a sua alta freqüência de reposição, gastou-se mais que $160 \%$ do valor gasto na compra dos tubos em aço inoxidável 304 com 1,50 mm de espessura, os de valor mais elevado. Quando esta comparação é feita com tubos em aço inox 439, esta diferença é maior que 300\%;

- O componente de custo transporte tem uma contribuição pequena nos custos contábeis totais deste estudo. Independente disso, pôde-se constatar a influência danosa da alta freqüência de substituição dos tubos em aço carbono. O custo do transporte destes tubos é 600 a 900\% maior que os dos tubos em aços inoxidáveis. 
- Com relação ao componente de custo instalação/substituição dos tubos, o maior número de tubos por evaporador e a alta frequêencia de substituição dos tubos em aço carbono faz com que este custo contábil seja $470 \%$ maior que os custos correspondentes às unidades que utilizam os diferentes tipos de aços inoxidáveis. Este custo, independente do seu alto valor, como acontece durante todo o ano e não com as freqüências determinadas, como as usadas neste trabalho, em muitas usinas ele é absorvido pelos "custos de manutenção" da empresa, não merecendo a devida atenção em separado.

- O componente de custo limpeza dos tubos quando avaliado a longo prazo pode causar impacto, tendo em vista os altos valores que pode alcançar para todos os tipos de tubos. Independente disso, cabe salientar que o custo contábil da limpeza dos tubos em aço carbono é ainda $60 \%$ maior, que o custo correspondente aos tubos em inox.

- A venda das sucatas dos tubos fabricados com os aços 439 e 444 gera pequenas receitas contábeis, devido ao baixo preço destas sucatas. Mesmo para o aço 444 que contém molibdênio, um metal caro, a sua sucata é comprada como sucata ferrítica, sem nenhuma distinção. Neste parâmetro fica evidente o alto valor agregado da sucata dos tubos em aço 304.

- A comparação dos custos contábeis totais das diferentes unidades em estudo causa, sem dúvida, algumas surpresas, ou seja:

- O custo contábil total para a unidade tubos em aço carbono é $235 \%$ maior que o custo contábil para a unidade tubos em aço inoxidável 444 com $1,50 \mathrm{~mm}$ de espessura, que é a unidade em aço inoxidável de maior custo contábil total;

- Os custos contábeis totais para as unidades tubos em aço inoxidável 304 com 1,20 e 1,50 mm de espessura são menores do que os custos contábeis totais para todas as demais unidades, em função dos altos valores recebidos pela venda das sucatas.

A comparação dos custos contábeis totais num primeiro momento, colocaria por terra a "crença" do baixo custo do aço carbono, fruto de uma visão de curto prazo para um investimento que, na realidade, é de longo prazo. Entretanto, a visão 
contábil é inadequada para avaliação de decisões de investimento, porque não considera o custo do dinheiro no tempo.

\subsubsection{Valor Presente Líquido - VPL}

O custo contábil total de uma unidade, por exemplo, tubos em aço carbono com 2,65 mm de espessura, representou o somatório dos valores futuros de investimentos e despesas realizados durante o tempo de estudo. De forma semelhante, o valor presente líquido $\left(\mathrm{VP}_{\mathrm{L}}\right)$ das unidades em estudo, igual ao somatório dos VP dos vários componentes de custo, é o valor atual de um montante futuro, que poderia ser investido hoje, a uma dada taxa de juros, durante o período de trinta anos, para se igualar ao montante futuro. Ou seja, o $\mathrm{VP}_{\mathrm{L}}$ mede a "oportunidade" de um investimento em um dado período de tempo. Desta forma, usando o conceito de fluxo de caixa, quanto maior for $O V P_{L}$ de uma unidade, mais atraente ela é para investimento.

A Tabela 34 relaciona os VP para as unidades que compõe este estudo, discriminados pelos componentes de custo utilizados. A última coluna a direita, $\mathrm{VP}_{\mathrm{L}}$, apresenta o somatório destas atualizações financeiras ao tempo zero do estudo, para cada unidade. Estes valores representam a oportunidade relativa para cada tipo de tubo, ou seja, a unidade que apresentar o maior $V P_{L}$ é a melhor opção de escolha, do ponto de vista financeiro. Como nesta Tabela foi usado o conceito de fluxo de caixa, onde os desembolsos são apresentados entre parênteses (valor negativo) e as receitas correspondem a crédito (valor positivo), como todos os $\mathrm{VP}_{\mathrm{L}}$ estão entre parênteses, a melhor opção de investimento é aquela que corresponde ao menor valor numérico entre parênteses, ou seja gastou-se menos naquele investimento.

Para facilitar a presente avaliação, será analisado o VP para cada componente de custo:

- O VP para a compra dos tubos é semelhante para as unidades relativas aos tubos em aço carbono e aço inoxidável 439. Todas as demais unidades relativas aos aços inoxidáveis apresentam VP menores que o do aço carbono, já que para aqueles, o maior gasto acontece exatamente no tempo zero do estudo. 
- Para o componente de custo transporte dos tubos, o VP da unidade tubos em aço carbono é menor que os valores relativos às diferentes unidades referentes aos tubos em aços inoxidáveis devido, principalmente, a sua alta freqüência de compras ao longo de todo o ciclo de vida.

- A instalação e a substituição dos tubos são etapas de custo elevado na manutenção de evaporadores. O maior número de tubos e a alta freqüência de substituição fazem com que a unidade tubos em aço carbono fique em uma situação muito desvantajosa com relação às unidades tubos em aços inoxidáveis, quando se considera o custo do dinheiro no tempo.

- Situação semelhante acontece com o componente de custo limpeza dos tubos, mais um item da manutenção que vem favorecer financeiramente as unidades constituídas pelos diferentes tipos de tubos dos aços inoxidáveis. Contribuíram para estes resultados desfavoráveis ao aço carbono o maior número de tubos a serem limpos e, principalmente, a maior freqüência de limpeza.

- Para o componente de custo venda das sucatas, o VP para as unidades relativas aos aços inoxidáveis redundou em um pequeno significado financeiro para estes materiais. Isto aconteceu porque a quase totalidade destas sucatas foram vendidas no final do ciclo de vida do estudo e quando estes valores monetários são trazidos ao VP, com uma alta taxa de juros, perdem a quase totalidade do seu valor financeiro. Devido a isso, o VP para a unidade tubos em aço carbono ainda foi o de maior contribuição, já que os créditos relativos às vendas, mesmo que pequenos, aconteceram ao longo de todo o ciclo de vida.

- A última coluna a direita, $\mathrm{VP}_{\mathrm{L}}$, apresenta o somatório dos VP de todos os componentes de custo para as unidades que compõem o estudo. Como comentado anteriormente, a unidade que apresentar o maior $\mathrm{VP}_{\mathrm{L}}$, é a que oferece a maior oportunidade financeira de investimento. Assim sendo, a unidade tubos em aço inoxidável 439 é a mais interessante, seguida pelas unidades tubos em aço inoxidável $444 \mathrm{com} \mathrm{1,20} \mathrm{e} \mathrm{1,50} \mathrm{mm} \mathrm{de} \mathrm{espessura.} \mathrm{As} \mathrm{unidades} \mathrm{tubos} \mathrm{em}$ aço carbono e tubos em aço inoxidável $304 \mathrm{com} 1,20 \mathrm{~mm}$ de espessura são iguais, considerando o nível de incerteza natural de um estudo deste tipo. Desta forma, apenas o $\mathrm{VP}_{\mathrm{L}}$ relativo aos tubos em aço inoxidável $304 \mathrm{com} 1,50 \mathrm{~mm}$ de espessura é menos interessante financeiramente que a unidade tubos em aço carbono. 
Tabela 33 - Custos contábeis relativos aos diferentes tipos de tubos de aço analisados

\begin{tabular}{|l|c|c|c|c|c|c|}
\hline \multirow{2}{*}{ UNIDADES } & \multicolumn{5}{|c|}{ VALORES (R\$) } \\
\cline { 2 - 6 } & $\begin{array}{c}\text { Compra dos } \\
\text { Tubos }\end{array}$ & $\begin{array}{c}\text { Transporte dos } \\
\text { Tubos }\end{array}$ & $\begin{array}{c}\text { Instalação / } \\
\text { Substiçacão } \\
\text { dos Tubos }\end{array}$ & $\begin{array}{c}\text { Limpeza dos } \\
\text { Tubos }\end{array}$ & $\begin{array}{c}\text { Venda Sucata } \\
\text { Custo Contábil } \\
\text { Total }\end{array}$ \\
\hline Tubos Aço Carbono, 2,65 mm & $(2.605 .991,00)$ & $(73.792,00)$ & $(1.434 .316,00)$ & $(1.387 .555,00)$ & $365.628,00$ & $(5.136 .026,00)$ \\
\hline Tubos Inox 439, 1,50 mm & $(845.735,00)$ & $(8.449,00)$ & $(304.445,00)$ & $(863.520,00)$ & $135.605,00$ & $(1.886 .544,00)$ \\
\hline Tubos Inox 444, 1,20 mm & $(910.156,00)$ & $(7.962,00)$ & $(299.253,00)$ & $(846.052,00)$ & $109.787,00$ & $(1.953 .636,00)$ \\
\hline Tubos Inox 444, 1,50 mm & $(1.129 .895,00)$ & $(9.939,00)$ & $(304.445,00)$ & $(863.520,00)$ & $137.859,00$ & $(2.169 .940,00)$ \\
\hline Tubos Inox 304, 1,20 mm & $(1.276 .808,00)$ & $(9.863,00)$ & $(299.253,00)$ & $(846.052,00)$ & $992.162,00$ & $(1.439 .814,00)$ \\
\hline Tubos Inox 304, 1,50 mm & $(1.602 .422,00)$ & $(12.389,00)$ & $(304.445,00)$ & $(863.520,00)$ & $1.247 .990,00$ & $(1.534 .786,00)$ \\
\hline
\end{tabular}

Observações: Foi utilizado nesta Tabela o conceito de fluxo de caixa. Os desembolsos são apresentados entre parênteses (valor negativo). As receitas correspondem a crédito (valor positivo)

Dados extraídos das Tabelas 28, 29, 30, 31 e 32. 
Tabela 34 - Valores presentes relativos aos diferentes tipos de tubos de aço analisados

\begin{tabular}{|c|c|c|c|c|c|c|}
\hline \multirow{2}{*}{ UNIDADES } & \multicolumn{6}{|c|}{ VALOR PRESENTE (R\$) } \\
\hline & $\begin{array}{c}\text { Compra dos } \\
\text { Tubos }\end{array}$ & $\begin{array}{c}\text { Transporte dos } \\
\text { Tubos }\end{array}$ & $\begin{array}{c}\text { Instalação / } \\
\text { Substituição } \\
\text { dos Tubos }\end{array}$ & $\begin{array}{c}\text { Limpeza dos } \\
\text { Tubos }\end{array}$ & Venda Sucata & $\begin{array}{l}\text { Valor Presente } \\
\text { Líquido }\left(\mathrm{VP}_{\mathrm{L}}\right)\end{array}$ \\
\hline Tubos Aço Carbono, 2,65 mm & $(801.761,00)$ & $(22.703,00)$ & $(323.628,00)$ & $(453.242,00)$ & $58.518,00$ & $(1.542 .816,00)$ \\
\hline Tubos Inox 439, 1,50 mm & $(800.841,00)$ & $(8.000,00)$ & $(83.029,00)$ & $(282.067,00)$ & $5.696,00$ & $(1.168 .241,00)$ \\
\hline Tubos Inox 444, 1,20 mm & $(861.827,00)$ & $(7.540,00)$ & $(81.613,00)$ & $(276.361,00)$ & $4.613,00$ & $(1.222 .728,00)$ \\
\hline Tubos Inox 444, 1,50 mm & $(1.069 .915,00)$ & $(9.412,00)$ & $(83.029,00)$ & $(282.067,00)$ & $5.791,00$ & $(1.438 .783,00)$ \\
\hline Tubos Inox 304, 1,20 mm & $(1.209 .032,00)$ & $(9.339,00)$ & $(81.613,00)$ & $(276.361,00)$ & $41.676,00$ & $(1.534 .669,00)$ \\
\hline Tubos Inox 304, 1,50 mm & $(1.517 .359,00)$ & $(11.731,00)$ & $(83.029,00)$ & $(282.067,00)$ & $52.422,00$ & $(1.841 .764,00)$ \\
\hline
\end{tabular}

Observações: Foi utilizado nesta Tabela o conceito de fluxo de caixa. Os desembolsos são apresentados entre parênteses (valor negativo). As receitas correspondem a crédito (valor positivo).

Dados extraídos das Tabelas 28, 29, 30, 31 e 32. 


\section{CONCLUSÕES}

O presente trabalho de tese de doutorado teve como objetivos as comparações de desempenho ambiental e financeiro de um sistema de evaporação para usinas de açúcar, cujos tubos de troca térmica são construídos em aço carbono com 2,65 mm de espessura e, comparativamente, com os aços inoxidáveis 304, 444 e 439. Para os dois primeiros foram usados tubos com 1,20 mm e 1,50 mm de espessura, respectivamente. Para o aço 439 foram usados tubos com $1,50 \mathrm{~mm}$. 0 período de tempo desta análise foi de trinta anos.

Para a avaliação ambiental foi utilizada a metodologia de Avaliação do Ciclo de Vida (ACV). Com base no objetivo e no escopo deste estudo de ACV, concluiu-se que:

1) o sistema de produto tubos em aço carbono com $2,65 \mathrm{~mm}$ de espessura apresentou um desempenho ambiental inferior aos sistemas de produto tubos em aços inoxidáveis 304, 444 e 439, nas espessuras de 1,20 e 1,50 mm, pois emitiu mais que:

$>4,2$ vezes a quantidade de dióxido de carbono;

$>2,8$ vezes a quantidade de óxidos de nitrogênio;

> 3,1 vezes a quantidade de materiais particulados;

> 13 vezes a quantidade de materiais suspensos;

$>4,5$ vezes a quantidade de resíduos totais.

2) de forma semelhante, o sistema de produtos tubos em aço carbono consumiu mais que:

> 11 vezes o total de recursos naturais não renováveis (carvão metalúrgico; lignita; calcita; dolomita; óleo bruto; gás natural e minérios de ferro, cromo, níquel, molibdênio e manganês);

> 1,8 vezes a quantidade de água utilizada; $\mathrm{e}$,

$>5$ vezes a quantidade de energia primária total.

3) o sistema de produto tubos em aço carbono é menos impactante ao meio ambiente quando comparado com os sistemas de produtos tubos em aço 
inoxidável 304 quanto à emissão de óxidos de enxofre, já que emitiu a metade, aproximadamente, deste aspecto ambiental.

4) os sistemas de produtos tubos em aço carbono e tubos em aços inoxidáveis 444 e 439 emitiram quantidades semelhantes de óxidos de enxofre.

5) as emissões de óxidos de enxofre dos sistemas de produtos tubos em aços inoxidáveis informadas neste estudo estão superestimadas, tendo em vista a matriz energética dos países em que os dados de ICV foram coletados ter uma predominância da termoeletricidade.

Para a avaliação financeira foi utilizada a técnica de Custeio do Ciclo de Vida (CCV). Para os fatores de custos estudados e tendo em vista as condições econômicas e financeiras atuais concluiu-se que:

6) os tubos fabricados com os aços inoxidáveis 439 e 444 apresentaram-se como opções de investimento mais interessantes que os tubos fabricados em aço carbono, já que apresentaram custos trazidos ao valor presente $\left(\mathrm{VP}_{\mathrm{L}}\right)$ menores, nas seguintes proporções:

> Tubos em aço $439 \mathrm{com} \mathrm{1,50} \mathrm{mm} \mathrm{igual} \mathrm{a} \mathrm{0,76;}$

$>$ Tubos em aço $444 \mathrm{com} 1,20 \mathrm{~mm}$ igual a 0,79; e,

> Tubos em aço $444 \mathrm{com} \mathrm{1,50} \mathrm{mm} \mathrm{igual} \mathrm{a} \mathrm{0,93.}$

7) Os tubos fabricados com aço carbono e os tubos fabricados com aço inoxidável 304 com $1,20 \mathrm{~mm}$ de espessura mostraram-se opções de investimento semelhantes.

8) Os tubos fabricados com aço inoxidável 304 com $1,50 \mathrm{~mm}$ de espessura são opções de investimento menos atraentes que os tubos em aço carbono com 2,65 mm de espessura, já que apresentaram custos trazidos ao valor presente $\left(\mathrm{VP}_{\mathrm{L}}\right) 1,19$ vezes maior.

9) As metodologias de ACV e CCV devem ser usadas em conjunto, pois mostram que produtos mais seguros ambientalmente podem vir a ser opções de investimento também mais interessantes, quando avaliadas ao longo do ciclo de vida do produto. 


\section{SUGESTÕES PARA TRABALHOS FUTUROS}

As conclusões deste trabalho de tese de doutorado mostraram a oportunidade para dois trabalhos, pelo menos. Eles são:

1- Avaliação do desempenho ambiental e financeiro de equipamentos, tubulações, tanques, chapas e barras usados nas usinas de açúcar, fabricados em aço carbono e, comparativamente, com diferentes tipos de aços inoxidáveis.

2- Desenvolvimento de estudos de avaliação do ciclo de vida para a produção de aço carbono e diferentes aços inoxidáveis no Brasil. 


\section{REFERÊNCIAS}

1) RORIZ, J. As novas fronteiras da cana. Revista Dinheiro Rural, São Paulo, v. 3, n. 17, p 24-26, mar. 2006.

2) CHEHEBE, J. R. B. Análise do ciclo de vida de produtos: ferramenta gerencial da ISO 14.000. Rio de Janeiro: Qualitymark, 1998.

3) MATERN, S. Life cycle cost LCC: a new approach to materials selection: engineering and economy. Avesta Sheffield, Information 9763. Disponível em: <www.avestasheffield.com>. Acesso em: 13 maio 2002.

4) MOURA, L. A. A. Qualidade e gestão ambiental. 2.ed. São Paulo: Juarez de Oliveira, 2000.

5) CASTRO, N. (Coord.). A questão ambiental e as empresas. Brasília: Sebrae, 1998.

6) MOURAD, A. L.; GARCIA, E. E. C.; VILHENA, A. Avaliação do ciclo de vida: princípios e aplicações. Campinas: CETEA/ITAL, 2002.

7) INTERNATIONAL ORGANIZATION FOR STANDARDIZATION. ISO 14040: environmental management: life cycle assessment: princicles and framework. Bruxells, 1997.

8) _. ISO 14041: environmental management: life cycle assessment: goal and scope definition and inventory analysis. Bruxells, 1998.

9) _ ISO 14042: environmental management: life cycle assessment: life cycle impact assessment. Bruxells, 2000.

10) _. ISO 14043: environmental management ILife cycle assessment: life cycle interpretation. Bruxells, 2000.

11) Bruxells, 2001.

ISO TR 14047: illustratives examples on how to apply ISO 14042. 
12) LCA data documentation format. Bruxells. 2002.

13) ISO TR 14049: environmental management: life cycle assessment: examples for the application of ISO 14041 to goal scope definition and inventory analysis. Bruxells, 2000.

14) FAVA, J. A. (Ed.). A technical framework for life cycle assessment. Washington: SETAC, 1991. $134 \mathrm{p}$.

15) ECOBILAN. Neuilly-sur-Seine. Life cycle assessment history. Disponível em: <www.ecobalance.com $>$. Acesso em: 15 nov. 2006.

16) BLOUET, A.; RIVOIRE, E. L'écobilan: les produits et leurs imputs sur I' environnement. Paris: DUNOD, 1995.

17) CRHRISTIANSEN, K. Life cycle assessment in a historical perspective: In: . Environmental assessment of products: a textbook on life cycle assessment. $2^{\text {th }}$ ed. Helsinki: UETP/EEE, 1993.

18) SOCIETY OF ENVIRONMENTAL TOXICOLOGY AND CHEMISTRY. A conceptual framework for life cycle impact assessment. Pensacola: SETAC, 1993.

19) LEVY, M. Applications of LCA impact assessment. Canadá, 1995. Documento técnico apresentado para o ISO / TC 207 / SC 5 / WG-01: life cycle impact assessment.

20) ALMEIDA, S. M. G. Estudo da técnica de análise do ciclo de vida e sua aplicação como ferramenta de gestão ambiental nas empresas. 1998. 232p. Dissertação (Mestrado) - COPPE, Universidade Federal do Rio de Janeiro, Rio de Janeiro, 1998.

21) ASSOCIAÇÃO BRASILEIRA DE NORMAS TÉCNICAS. NBR ISO 14040: gestão ambiental: avaliação do ciclo de vida - princípios e estrutura. Rio de Janeiro, 2001.

22) _. NBR ISO 14041: gestão ambiental: avaliação do ciclo de vida: definição de objetivo e escopo e análise de inventário. Rio de Janeiro, 2004. 
23)__ NBR ISO 14042: gestão ambiental: avaliação do ciclo de vida: avaliação do impacto do ciclo de vida. Rio de Janeiro, 2004.

24) __ NBR ISO 14043: gestão ambiental: avaliação do ciclo de vida: interpretação do ciclo de vida. Rio de Janeiro, 2005.

25)__ NBR ISO 14050: gestão ambiental: vocabulário. Rio de Janeiro, 2004.

26) PAOLA, J. C. C. Análise ambiental de aços forjados. 2004. 163p. Tese (Doutorado) - Escola Politécnica, Universidade de São Paulo, São Paulo, 2004.

27) RIBEIRO, P. H. Modelagem de sistemas de produto em estudos de Avaliação do Ciclo de Vida - ACV. 135p. Dissertação (Mestrado) - Escola Politécnica, Universidade de São Paulo, São Paulo, 2004.

28) CURRAN, M. A. Environmental life-cycle assessment: inventory guidelines and principles. New York: Mc Graw-Hill, 1996. 144p.

29) WENZEL, H.; HAUSCHILD, M.; ALTING, L. Environmental assessment of products. London: Chapman \& Hall, 2000. v.1,543 p.

30) KULAY, L. A. Uso da análise do ciclo de vida para a comparação do desempenho ambiental das rotas úmida e térmica de produção de fertilizantes fosfatados. 314p. Tese (Doutorado) - Escola Politécnica, Universidade de São Paulo, São Paulo, 2004.

31)CARVALHO, C. E. A análise do ciclo de vida e os custos completos no planejamento energético. 228p. Dissertação (Mestrado) - Escola Politécnica, Universidade de São Paulo, São Paulo, 2000.

32)JENSEN, A. A. et al. Life cycle assessment (LCA): a guide to approaches, experiences and information sources. London: EEA, 1997. (Environmental issues series, n.6).

33) SPECIALTY STEEL INDUSTRY OF NORTH AMERICA. Introduction to life cycle costing for stainless steel. Washington: SSINA. Disponível em: $<$ www.ssina.com $>$. Acesso em: 11 jul. 2002. 
34) NÚCLEO DE DESENVOLVIMENTO TÉCNICO MERCADOLÓGICO DO AÇO INOXIDÁVEL. Manual de aplicação da metodologia LCC: life cycle costing. São Paulo: Núcleo Inox, 1999. 12p.

35) THE INTERNATIONAL CHROMIUM DEVELOPMENT ASSOCIATION (ICDA), EURO INOX ; THE EUROPEAN STAINLESS STEEL DEVELOPMENT ASSOCIATION (SASSDA). Life Cycle Costing (LLC) Help Texts. Disponível em: <www.chromium-asoc.com>. Acesso em: 11 maio 2002.

36) THE INTERNATIONAL CHROMIUM DEVELOPMENT ASSOCIATION (ICDA), EURO INOX ; THE EUROPEAN STAINLESS STEEL DEVELOPMENT ASSOCIATION (SASSDA). The life cycle costing of stainless steel. Disponível em: <www.chromium-asoc.com>. Acesso em: 11 maio 2002.

37) GITMAN, L. J. Princípios de administração financeira. 7. ed. São Paulo: Harbra, 1997. 841p.

38)CHEN, J. C. P. Manual del azúcar de cana. New York: John Wiley, 1996. 1090p.

39)DELGADO, A. A., CÉSAR, M. A. A. Elementos de tecnologia e engenharia do açúcar de cana. Piracicaba: ESALQ, 1992. 1061p. (Publicação, n. 54354).

40)HONIG, P. Princípios de tecnologia açucareira. S.I.: Continental, 1969. v.3.

41)HUGOT, E., 1970. La sucrerie de cannes. 2.ed. Paris: Dunod, 1970. 989p.

42)PERRY's chemical engineers' handbook. $5^{\text {th }}$ ed. New York: McGraw-Hill, 1973.

43)LUSTENADER, E. L; STAUB, F. W. Development contribution to compact condenser design. In: INTERNATIONAL NICKEL COMPANY POWER CONFERENCE, Brussels, 1964. Proceedings... Brussels: NCP, 1964.

44)AMERICAN IRON AND STEEL INSTITUTE. Committee of Stainless Steel Producers. Jamshedpur. Stainless steels for evaporators and concentrators. Disponível em: <www.steelworld.com>. Acesso em: 15 mar. 2006. 
45)PERSICO PIZZAMIGLIO S.A. Catálogos sobre fabricação e produtos. Disponível em: http://www.pipesystem.com.br/ArtigosTecnicos/TubosAco/bodytubosaco.html. Acesso em: 15 out. 2006.

46)THOMAS, W. B. Calefacción y evaporación. In: CHEN, J. C. P. Manual del azúcar de caña. S.I: Limusa Noriega, 1996. cap. 9.

47)SUGAR ENGINEERS' LIBRARY. Sugar factory tubes for heating, evaporating and crystallising. Disponível em:<www.sugartech.co.za $>$. Acesso em: 20 maio 2006.

48)___ Specification for vacuum pan, evaporators and juice heater tubes more than three metres long. Disponível em: <www.sugartech.co.za $>$. Acesso em: 20 maio 2006.

49)_. Specification for vacuum pan, evaporators and juice heater tubes less than three metres long. Disponível em: <www.sugartech.co.za $>$. Acesso em: 20 maio 2006.

50) ACESITA S. A. O aço inoxidável na indústria de açúcar. São Paulo, SP, [200-]

51) CARBÓ, H. M. Núcleo de desenvolvimento técnico mercadológico do aço inoxidável. In: AÇO inoxidável: aplicações e especificações. São Paulo: Núcleo Inox, 2001. Disponível em:

http://www.nucleoinox.com.br/new/downloads/Acesita Aplica Especifica.pdf Acesso em: 04 fev. 2007.

51)NICKEL DEVELOPMENT INSTITUTE. Design guidelines for the selection and use of stainless steel. Toronto: NDI, 1987. (The designer's handbook series).

52) ACESITA S. A. São Paulo. Manual técnico de aços inoxidáveis: características básicas e cuidados. São Paulo, SP, [s.d.].

53)HUGOT, E. Manual da engenharia açucareira. São Paulo: Mestre Jou, 1977.

54)TUTHILL, A. H. The right metal for heat exchanger tubes. Toronto, Ontário, 1990. (Nickel Development Institute technical Series № 10040). 
55) INTERNATIONAL IRON AND STEEL INSTITUTE. Application of the IISI data to recycling scenarios: appendix 5. Brussels: IISI. 2002. (Life cycle inventory methodology repor).

56) INTERNATIONAL STAINLESS STEEL FORUM. Brussels. 2005. LCI and LCA data to stainless steel production. Disponível em: $<$ www.extranet.worldstainless.org/worldstainless/portal/categories/lci lca/>. Acesso em: 11 jul. 2006.

57)SINGLETON, R. W. Steel. In: KIRK-OTHMER encyclopedia of chemical technology. New York: Wiley.Interscience,1991. v. 22, p. $802-835$ p.

58)WESTBROOK, J. H. Chromium and chromium alloys. In: KIRK-OTHMER encyclopedia of chemical technology. New York: Wiley Interscience, 1991. v. 6 , p. $228-263$ p.

59)TUNDERMANN, J. H.; TIEN, J. K.; HOWSON, T. E. Nickel and nickel alloys. In: KIRK-OTHMER encyclopedia of chemical technology. New York: Wiley.Interscience, 1991. v. 17, p. 1-17p.

60) SCHELEWITZ, J. H. Niobium and niobium compounds. In: KIRK-OTHMER encyclopedia of chemical technology. New York: Wiley.Interscience, 1991. v. 17 , p. $43-64$ p.

61) MATRICARDI, L. R.; DOWNING, J. Titanium and titanium alloys. In: KIRKOTHMER encyclopedia of chemical technology. New York: Wiley.Interscience, 1991. v. 24, p.186-209p.

62) BOMBERGER, H. B. Manganese and manganese alloys. In: KIRK-OTHMER encyclopedia of chemical technology. New York: Wiley.Interscience, 1991. v.15, p. 964-990p.

63) DOANE, V. D.; TIMMONS, G. A.; HALLADA, C. J. Molybdenum and molybdenum alloys. In: KIRK-OTHMER encyclopedia of chemical technology. New York: Wiley.Interscience, 1991. v.16, p.925-939p.

64) FONTANA, M. G.; GREENE, N. D. Corrosion Engineering. 2. ed. Auckland: MC Graw-Hill, 1982. 465p. 
65) NAGAIWA, T. Recycling methodology for stainless steel. In: INTERNATIONAL STAINLESS STEEL FORUM. Brussels. 2004. Disponível em: <www.worldstainless.org $>$. Acesso em: 12 maio 2006.

66) AMATO, A.; BRIMACOMBRE, L.; HOWARD, N. (1996) Development of quantitative methodology for assessing embodied energy of recyclabe and reusable materials/products. Ironmaking and Seelmaking, London, v. 23, n. 3, p. 325-241.

67) WHITE MARTINS. Rio de Janeiro. Gás natural. Disponível em: http://www.whitemartins.com.br/sites/produtosserviços/industriaiswn035725.jsp. Acesso em: 17 fev. 2007.

68) BRASIL. Agência Nacional do Petróleo, Gás Natural e Bio-Combustíveis. Condições padrões de medição $-20^{\circ} \mathrm{C}, 101,325 \mathrm{kPa}$. Portaria ANP № 104, de 08.07.2002. Diário Oficial [da] República Federativa do Brasil, Poder Executivo, Brasília, DF, 09 jul. 2002. 


\section{GLOSSÁRIO}

No sentido de familiarizar o público alvo deste trabalho com o vocabulário técnico característico da $\mathrm{ACV}$, providenciou-se este glossário de termos técnicos, por ordem alfabética, inerente ao assunto ${ }^{25}$ :

- alocação: Repartição dos fluxos de entrada ou de saída de uma unidade de processo no sistema de produto sob estudo.

- análise se incerteza: Procedimento sistemático para verificar e quantificar a incerteza introduzida nos resultados de uma análise de inventário do ciclo de vida pelos efeitos cumulativos das incertezas das entradas e da variabilidade dos dados.

Nota: São utilizados faixas ou distribuições de probabilidade para determinar a incerteza dos resultados.

- análise de sensibilidade: Procedimento sistemático para estimar os efeitos dos métodos e dados selecionados nos resultados de um estudo.

- análise do inventário do ciclo de vida (ICV): Fase da avaliação do ciclo de vida envolvendo a compilação e a quantificação de entradas e saídas, para um determinado sistema de produto ao longo do seu ciclo de vida.

- aspecto ambiental: Elemento das atividades, produtos ou serviços de uma organização, que pode interagir com o meio ambiente.

- avaliação de desempenho ambiental (ADA): Processo utilizado para facilitar as decisões gerenciais relativas ao desempenho ambiental de uma organização e que compreende a seleção de indicadores, a coleta e análise de dados, a avaliação da informação em comparação com os critérios de desempenho ambiental, os relatórios e os informes, as análises críticas periódicas e as melhorias deste processo.

- avaliação do ciclo de vida (ACV): Compilação e avaliação das entradas, das saídas e dos impactos ambientais potenciais de um sistema de produto ao longo do seu ciclo de vida.

- avaliação do impacto do ciclo de vida (AICV): Fase da avaliação do ciclo de vida dirigida a compreensão e à avaliação da magnitude e significância dos impactos ambientais potenciais de um sistema de produto.

- característica funcional do produto: Atributo ou característica no desempenho e no uso de um produto. 
- carga ambiental: Parâmetro que representa a somatória de aspectos ambientais associados a uma corrente material ou energética.

- categoria de impacto: Classe que representa as questões ambientais de interesse na qual os resultados do ICV podem ser determinados.

- certificação: Procedimento pelo qual uma terceira parte dá garantia escrita de que um produto, processo ou serviço está em conformidade com os requisitos especificados.

- ciclo de vida: Estágios sucessivos e encadeados de um sistema de produto, desde a aquisição da matéria-prima ou geração de recursos naturais à disposição final.

- co-produto: Qualquer de dois ou mais produtos do mesmo processo elementar.

- correntes (ou fluxos): Quantidades de matéria ou energia que transpassam uma fronteira.

- correntes (ou fluxos) elementares: Material ou energia que entra no sistema sob estudo, que foi retirado do meio ambiente sem transformação prévia ou que sai do sistema em estudo sem transformação humana subseqüente.

- critérios ambientais de produto: requisitos ambientais aos quais o produto deve atender para que conquiste um rótulo ambiental.

- dados primários: Dados coletados diretamente junto às unidades de processo que compõem o sistema de produto onde se realiza a ACV.

- dados secundários: Dados obtidos em literaturas técnicas especializadas, geradas a partir de cálculos de engenharia ou de estimativas de projeto, ou ainda coletados junto a bancos de dados de ACV já elaborados.

- desempenho ambiental: Resultados da gestão de uma organização sobre seus aspectos ambientais.

Nota: No contexto dos sistemas de gestão ambiental, resultados podem ser medidos em relação à política ambiental de uma organização, aos objetivos ambientais e às metas ambientais.

- energia de processo: energia requerida por um processo elementar para operar o processo ou equipamento dentro do processo, excluindo entradas de energia para a produção e distribuição desta energia.

- entrada: Material ou energia que entra em uma unidade de processo. Nota: Materiais podem incluir matérias-primas e produtos. 
- fator de caracterização: Fator derivado de um modelo que é aplicado para converter resultados de ICV em uma unidade comum do indicador de categoria de impacto de ciclo de vida.

- fluxo de energia: entrada ou saída de um processo elementar ou sistema de produto, quantificada em unidades de energia.

- fluxo de referência: Medida das saídas necessárias de processos em um determinado sistema de produto, requeridas para realizar a função expressa pela unidade funcional.

- fluxo elementar: (1) Material ou energia que entra no sistema sob estudo, que foi retirado do meio ambiente sem transformação humana prévia. (2) Material ou energia que deixa o sistema sob estudo, que é descartado no meio ambiente sem transformação humana subseqüente.

- fronteira do sistema: Interfase entre um sistema de produto e o meio ambiente e outros sistemas de produto.

- impacto ambiental: Qualquer modificação do meio ambiente, adversa ou benéfica, que resulte, no todo ou em parte, das atividades, produtos ou serviços de uma organização.

- impacto final por categoria: Atributo ou aspecto no ambiente natural, na saúde humana ou nos recursos, que identifica uma questão ambiental de interesse.

- indicador de categoria de impacto do ciclo de vida: Representação quantificável da categoria de impacto.

- interpretação do ciclo de vida: Fase da avaliação do ciclo de vida na qual as constatações da análise de inventário ou da avaliação de impacto, ou de ambas, são combinadas consistentemente com o objetivo e o escopo definidos para obter conclusões e recomendações.

- meio ambiente: Circunvizinhança em que uma organização opera, incluindo ar, água, solo, recursos naturais, flora, fauna, seres humanos e suas inter-relações.

Nota: Neste contexto, circunvizinhança estende-se do interior das instalações para o sistema global.

- processo elementar: Menor porção de um sistema de produto para a qual são coletados dados quando é realizada uma avaliação do ciclo de vida.

- produto: quaisquer bens ou serviços. 
- resultado do inventário do ciclo de vida - resultado do ICV: Resultado da análise do inventário do ciclo de vida que inclui os fluxos que atravessam a fronteira do sistema e que fornece o ponto de partida para a avaliação do impacto do ciclo de vida.

- saída: Material ou energia que deixa um processo elementar.

Nota: Materiais podem incluir matérias-primas, produtos intermediários, produtos, emissões e resíduos.

- sistema de gestão ambiental (SGA): Parte do sistema de gestão global que inclui estrutura organizacional, atividades de planejamento, responsabilidades, práticas, procedimentos, processos e recursos para desenvolver, implementar, atingir, analisar criticamente e manter a política ambiental.

- sistema de produto: Conjunto de processos elementares, conectados material e energeticamente, que realiza uma ou mais funções definidas.

Nota 1: Para o propósito de avaliação do ciclo de vida, o termo "produto" usado isoladamente não inclui somente sistemas de produtos, mas podem também incluir sistemas de serviços.

Nota 2: Adaptada da ABNT NBR ISO $14040^{21}$.

- subproduto: Quantidade de matéria ou energia gerada por sistema cujo ciclo de vida ainda não foi concluído, podendo encontrar utilização em outros sistemas; difere do produto por não ser o objetivo de estudo da ACV.

- terceira parte: Pessoa ou organismo reconhecido como independente das partes envolvidas, no que se refere aos assuntos em questão.

Nota 1: "Partes envolvidas" representam geralmente os interesses do fornecedor ("primeira parte") e do comprador ("segunda parte").

Nota 2: "Terceira parte" não implica necessariamente o envolvimento de um organismo de certificação.

- transparência: Apresentação de informação de forma aberta, abrangente e compreensível.

- unidade funcional: Desempenho quantificado de um sistema de produto para uso como uma unidade de referência num estudo de avaliação de ciclo de vida.

- verificação de consistência: Processo para verificar se as hipóteses, os métodos e as informações são aplicadas consistentemente ao longo do estudo e se estão de acordo com a definição do objetivo e do escopo. 
Nota: Convém que seja realizada a verificação de consistência antes de se obterem as conclusões.

- verificação de integridade: Processo para verificar se as informações das fases precedentes de uma avaliação de ciclo de vida ou análise do inventário de ciclo de vida são suficientes para obter conclusões de acordo com a definição do objetivo e do escopo.

- verificação de sensibilidade: Processo para verificar se a informação obtida pela análise de sensibilidade é pertinente para obter as conclusões e dar recomendações. 
APÊNDICE A - Inventário do Ciclo de Vida para $1000 \mathrm{~kg}$ de Aço Carbono em Bobina

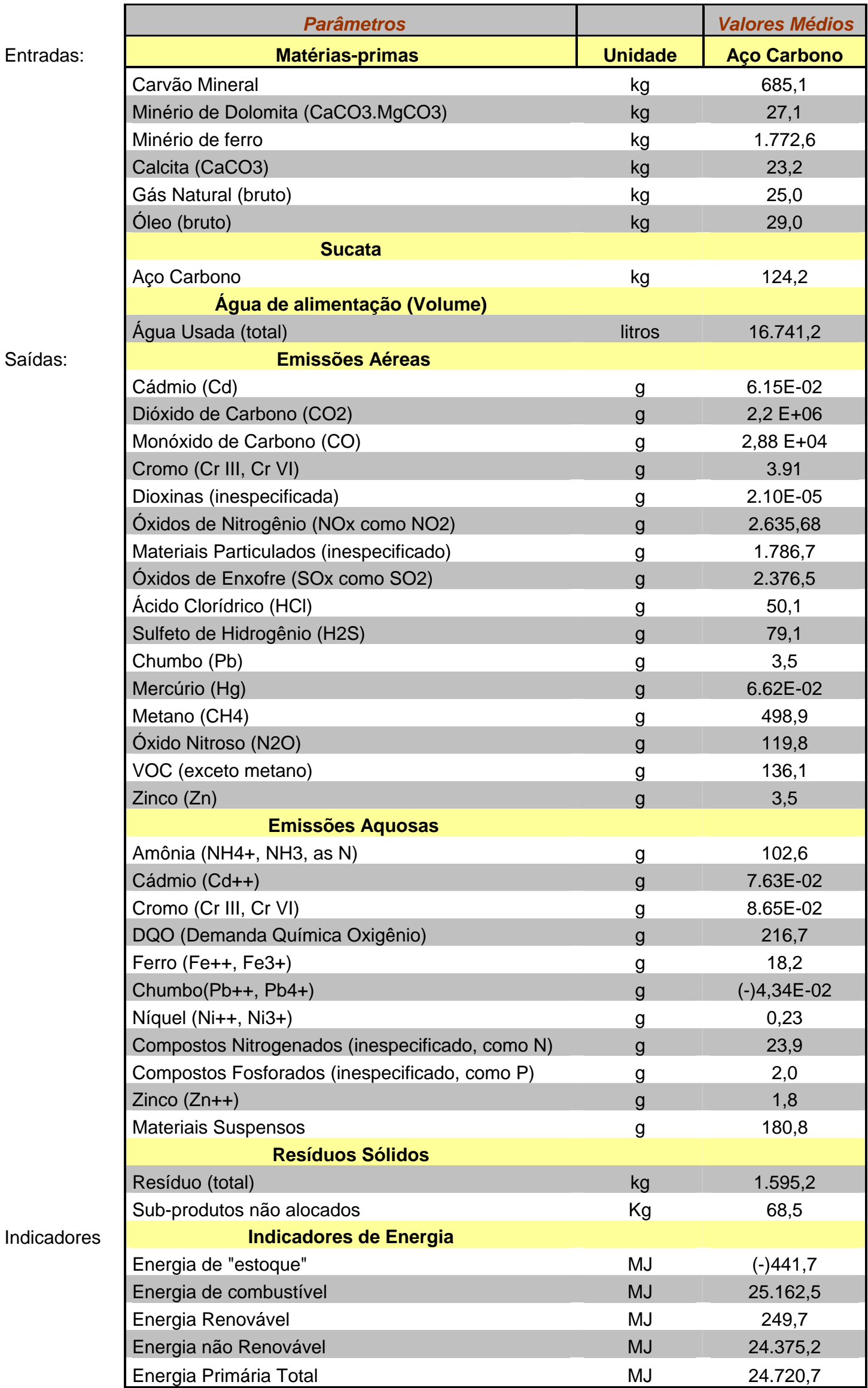

Fonte: Adaptado do World Steel Life Cycle Inventory - IISI ${ }^{56}$ 
APÊNDICE B - Inventário do Ciclo de Vida para 1000 kg dos Aços Inoxidáveis 304, 444 e 439 em Bobinas

Entradas:

\begin{tabular}{|l|l|}
\hline \multicolumn{1}{|c|}{ Marâmetros } & \\
\hline \multicolumn{1}{|c|}{ Matéria-prima } & Unida \\
\hline Minério de Cromo & \\
Carvão Mineral & \\
Dolomita (CaCO3.MgCO3) & \\
Minério de Ferro & \\
Lignita & \\
Calcita (CaCO3) & \\
Minério de Manganês & \\
Minério de Molibdênio & \\
Gás Natural (bruto) & \\
Minério de Níquel & \\
Óleo (bruto) Ferro-ligas & \\
Fe-Cr & \\
Fe-Ni & Fe-Ti \\
Fe-Nb Fe-Mo & \\
Fen
\end{tabular}

\begin{tabular}{|c|c|c|} 
& \multicolumn{3}{|c}{ Valores Médios } \\
\hline
\end{tabular}

\begin{tabular}{lcc|c}
$\mathrm{kg}$ & $\mathbf{3 0 4} \mathbf{2 B}$ & $\mathbf{4 4 4}$ & $\mathbf{4 3 9}$ \\
$\mathrm{kg}$ & 175,2 & 255,9 & 255,9 \\
$\mathrm{~kg}$ & 1129,6 & 1213,0 & 1258,2
\end{tabular}

$\begin{array}{ccc}1129,6 & 1213,0 & 1258,2\end{array}$

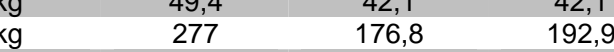

$\begin{array}{llll} & 58,7 & 46,3 & 46,3\end{array}$

$\begin{array}{llll}\mathrm{kg} & 210,7 & 175,6 & 182,1\end{array}$

$\begin{array}{lrrr}\text { kg } & 19,1 & 5,1 & 5,1\end{array}$

$\begin{array}{llll}\mathrm{kg} & 1,1 & 0,2 & 0,2\end{array}$

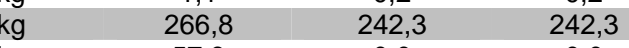

$\begin{array}{llll}\mathrm{kg} & 57,9 & 0,0 & 0,0\end{array}$

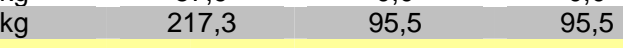

$\begin{array}{llll}\mathrm{kg} & 0,0 & 18,4 & 27,6\end{array}$

$\begin{array}{llll}\mathrm{kg} & 0,0 & 18,4 & 27,6 \\ \mathrm{~kg} & 0,0 & 12,5\end{array}$

$\begin{array}{llll}\mathrm{kg} & 0,0 & 10,7 & 10,7\end{array}$

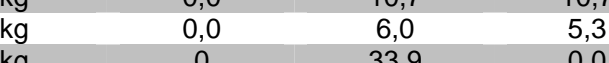

$\begin{array}{llll}\mathrm{kg} & 0 & 33,9 & 0,0\end{array}$

304 (fonte externa)

316

409

430

Outros Aços

Sucatas

$\begin{array}{llll}\mathrm{kg} & 458,9 & 0,5 & 0,5\end{array}$

$\begin{array}{ccc}25,4 & 0,0 & 0,0\end{array}$

$\begin{array}{cccc}\mathrm{kg} & 15,3 & 124,7 & 124,7 \\ \mathrm{~kg} & 19,2 & 97,2 & 97,2\end{array}$

$\begin{array}{llll}\mathrm{kg} & 37,5 & 29,3 & 29,3\end{array}$

\begin{tabular}{llccc} 
Aço Carbono & $\mathrm{kg}$ & 37,5 & 29,3 & 29,3 \\
\hline
\end{tabular}

Água de alimentação (Volume)

Água de Processo (resfriamento, total)

Água Usada (total)

Saídas:

Dióxido de Carbono (CO2)

Monóxido de Carbono (CO)

Cromo (Cr III, Cr VI)

Cromo ( $\mathrm{Cr} \mathrm{VI})$

Dioxinas (inespecificada)

Molibdênio (Mo, minério)

Níquel

Óxidos de Nitrogênio (NOx como NO2)

Materiais Particulados (inespecificado)

Óxidos de Enxofre (SOx como SO2)

Ácidos $(\mathrm{H}+)$ Emissões Aquosas

Alumínio (Al3+)

Amônia (NH4+, $\mathrm{NH} 3$, as $\mathrm{N}$ )

Cádmio $(\mathrm{Cd}++)$

Cloretos ( $\mathrm{Cl}-)$

Cromo (Cr III, Cr VI)

Cromo ( $\mathrm{Cr} \mathrm{VI})$

DQO (Demanda Química Oxigênio)

Hidrocarbonetos (inespecificados)

Ferro (Fe++, $\mathrm{Fe} 3+)$

Chumbo(Pb++, $\mathrm{Pb} 4+)$

Manganês (Mn II, IV, VII)

Molibdênio (Mo II, III, IV, V, VI)

Níquel $(\mathrm{Ni++}, \mathrm{Ni3}+)$

Nitrato (NO3-)

Compostos Nitrogenados (como N)

Compostos Fosforados (como P)

Dióxido de Silício (SiO2)

Compostos Sulfurados (como S)

Zinco $(\mathrm{Zn++})$

Materiais Suspensos

\section{Resíduos Sólidos}

Indicadores:

Resíduo (total)

Resíduo: proveniente produção de aço (total) Indicadores de Energia

\section{Energia de "estoque"}

Energia de combustível

Energia Renovável

Energia não Renováve

Energia Primária Total

Energia Elétrica

$\mathrm{MJ}$

litros $\quad 62.846,6 \quad 21.447,4 \quad 21.447,4$

\begin{tabular}{l|l|l|l|} 
litros & $17.700,7$ & $21.447,4$ & $21.447,4$ \\
\hline
\end{tabular}

\begin{tabular}{|c|c|c|c|}
\hline g & $6,10 \mathrm{E}+06$ & $5,35 E+06$ & $5,47 \mathrm{E}+06$ \\
\hline g & $10.047,6$ & $8.075,0$ & $8.075,0$ \\
\hline $\mathrm{g}$ & 91,9 & 129,7 & 133,3 \\
\hline g & 0,1 & 0,21 & 0,22 \\
\hline g & 9,00E-06 & $3,30 \mathrm{E}-07$ & 3,30E-07 \\
\hline g & 5,4 & 6,2 & 6,2 \\
\hline g & 77,9 & 30,9 & 30,9 \\
\hline g & $14.209,10$ & $12.931,8$ & $12.931,8$ \\
\hline g & $6.936,50$ & $5.708,8$ & $5.708,8$ \\
\hline g & $46.415,10$ & $22.793,4$ & $23.102,4$ \\
\hline g & 83,5 & 85,4 & 85,4 \\
\hline g & 22,7 & 25,5 & 25,5 \\
\hline $\mathrm{g}$ & 104,0 & 103,7 & 103,7 \\
\hline g & 0,2 & 0,2 & 0,2 \\
\hline g & $6.884,4$ & $6.650,1$ & $6.650,1$ \\
\hline $\mathrm{g}$ & 11,2 & 12,4 & 12,7 \\
\hline g & 8,1 & 8,5 & 8,7 \\
\hline $\mathrm{g}$ & $1.756,8$ & $1.768,6$ & $1.768,6$ \\
\hline g & 65,5 & 84,6 & 84,6 \\
\hline $\mathrm{g}$ & 147,0 & 130,1 & 132,7 \\
\hline $\mathrm{g}$ & 1,9 & 1,2 & 1,2 \\
\hline $\mathrm{g}$ & 6,7 & 8,2 & 8,2 \\
\hline $\mathrm{g}$ & 2,5 & 3 & 3 \\
\hline $\mathrm{g}$ & 8,5 & 11,2 & 11,2 \\
\hline $\mathrm{g}$ & 3261,4 & 3985,1 & 3985,1 \\
\hline $\mathrm{g}$ & 3984,9 & 292,8 & 292,8 \\
\hline $\mathrm{g}$ & 4,7 & 4,8 & 4,8 \\
\hline g & 362,5 & 453,1 & 453,1 \\
\hline $\mathrm{g}$ & 1498,2 & 1929,1 & 1929,1 \\
\hline $\mathrm{g}$ & 3,5 & 4,1 & 4,1 \\
\hline$g$ & 39,2 & 135,1 & 135,1 \\
\hline $\mathrm{kg}$ & $3.356,40$ & $1.396,1$ & $1.396,1$ \\
\hline $\mathrm{kg}$ & 169,1 & 151,8 & 151,8 \\
\hline MJ & $4.082,0$ & $2.948,5$ & $2.948,5$ \\
\hline MJ & $49.892,8$ & $45.665,4$ & $46.555,0$ \\
\hline MJ & $2.520,2$ & $2.086,7$ & $2.086,7$ \\
\hline MJ & $51.483,6$ & $43.500,0$ & $46.189,1$ \\
\hline MJ & $54.038,6$ & $45.585,0$ & $48.274,5$ \\
\hline $\mathrm{MJ}$ & $9.459,4$ & $9.368,2$ & $9.368,2$ \\
\hline
\end{tabular}

Fonte: Adaptado do World Stainless Steel LCI - ISSF ${ }^{57}$ 
Apêndice C - Inventário do Ciclo de Vida do Sistema de Produto de Tubos em Aço Carbono, com 2,65 mm de espessura

\begin{tabular}{|c|c|c|c|c|c|c|c|c|}
\hline \multirow{4}{*}{ Entradas: } & \multirow{2}{*}{\multicolumn{2}{|c|}{ Aspectos Ambientais }} & \multicolumn{6}{|c|}{ SUB-SISTEMAS } \\
\hline & & & \multirow{2}{*}{$\begin{array}{c}\text { Produção } \\
\text { Aço Carbono }\end{array}$} & \multirow{2}{*}{$\begin{array}{c}\text { Produção } \\
\text { Tubos } \\
\end{array}$} & \multirow{2}{*}{$\begin{array}{c}\text { Instalação } \\
\text { Tubos }\end{array}$} & \multirow{2}{*}{$\begin{array}{c}\text { Limpeza } \\
\text { Tubos } \\
\end{array}$} & \multirow{2}{*}{$\begin{array}{c}\text { Transporte } \\
\text { Tubos }\end{array}$} & \multirow{2}{*}{$\begin{array}{c}\text { Total } \\
\text { Consolidado } \\
\end{array}$} \\
\hline & Matérias-primas & Unidade & & & & & & \\
\hline & Carvão Mineral & $\mathrm{kg}$ & $4,110 \mathrm{E}+05$ & $0,00 E+00$ & $0,00 E+00$ & $0,00 E+00$ & $0,00 E+00$ & $4,11 E+05$ \\
\hline & Dolomita & $\mathrm{kg}$ & $1,62 E+04$ & $0,00 E+00$ & $0,00 E+00$ & $0,00 \mathrm{E}+00$ & $0,00 E+00$ & $1,62 E+04$ \\
\hline & Minério de Ferro & $\mathrm{kg}$ & $1,06 \mathrm{E}+06$ & $0,00 E+00$ & $0,00 E+00$ & $0,00 E+00$ & $0,00 E+00$ & $1,06 \mathrm{E}+06$ \\
\hline & Calcita & $\mathrm{kg}$ & $1,39 E+04$ & $0,00 E+00$ & $0,00 E+00$ & $0,00 E+00$ & $0,00 E+00$ & $1,39 E+04$ \\
\hline & Gás Natural & $\mathrm{kg}$ & $1,50 \mathrm{E}+04$ & $1,22 E+04$ & $0,00 E+00$ & $0,00 E+00$ & $0,00 \mathrm{E}+00$ & $2,57 \mathrm{E}+04$ \\
\hline & Óleo (bruto) & $\mathrm{kg}$ & $1,74 \mathrm{E}+04$ & $0,00 E+00$ & $0,00 E+00$ & $0,00 E+00$ & $0,00 E+00$ & $1,72 E+04$ \\
\hline & Óleo Diesel & $\mathrm{kg}$ & $0,00 E+00$ & $0,00 E+00$ & $0,00 E+00$ & $0,00 E+00$ & $1,70 \mathrm{E}+03$ & $8,81 E+03$ \\
\hline & Sucata & & & & & & & \\
\hline & Aço Carbono & $\mathrm{kg}$ & $7,45 E+04$ & $0,00 E+00$ & $0,00 E+00$ & $0,00 E+00$ & $0,00 E+00$ & $7,45 E+04$ \\
\hline & Água de alimentação (Volume) & & & & & & & \\
\hline & Água Usada (total) & litros & $1,00 \mathrm{E}+07$ & $0,00 E+00$ & $0,00 E+00$ & $5,29 E+07$ & $0,00 E+00$ & $6,29 \mathrm{E}+07$ \\
\hline \multirow[t]{13}{*}{ Saídas: } & Emissões Aéreas & & & & & & & \\
\hline & Cádmio (Cd) & $g$ & $3,69 E+01$ & $0,00 E+00$ & $0,00 E+00$ & $0,00 E+00$ & $0,00 E+00$ & $3,69 E+01$ \\
\hline & Dióxido de Carbono (CO2) & $g$ & $1,32 E+09$ & $3,29 E+07$ & $0,00 E+00$ & $0,00 E+00$ & $2,39 E+07$ & $1,38 E+09$ \\
\hline & Monóxido de Carbono (CO) & $g$ & $1,73 E+07$ & $0,00 E+00$ & $0,00 E+00$ & $0,00 E+00$ & $0,00 E+00$ & $1,73 E+07$ \\
\hline & Cromo (total) & $g$ & $2,34 E+03$ & $0,00 E+00$ & $0,00 E+00$ & $0,00 E+00$ & $0,00 E+00$ & $2,34 \mathrm{E}+03$ \\
\hline & Dioxinas (inespecificada) & $\mathrm{g}$ & $1,26 \mathrm{E}-02$ & $0,00 E+00$ & $0,00 E+00$ & $0,00 \mathrm{E}+00$ & $0,00 E+00$ & $1,26 \mathrm{E}-02$ \\
\hline & Óxidos de Nitrogênio (NOx como NO2) & g & $1,58 \mathrm{E}+06$ & $8,01 E+05$ & $0,00 E+00$ & $0,00 E+00$ & $0,00 E+00$ & $2,38 \mathrm{E}+06$ \\
\hline & Materiais Particulados (inespecificado) & $g$ & $1,07 E+06$ & $0,00 E+00$ & $0,00 E+00$ & $0,00 E+00$ & $0,00 E+00$ & $1,07 E+06$ \\
\hline & Óxidos de Enxofre (SOx como SO2) & g & $1,42 E+06$ & $1,13 E+03$ & $0,00 E+00$ & $0,00 \mathrm{E}+00$ & $0,00 \mathrm{E}+00$ & $1,45 E+06$ \\
\hline & Ácido Clorídrico $(\mathrm{HCl})$ & $g$ & $3,00 E+04$ & $0,00 E+00$ & $0,00 E+00$ & $0,00 E+00$ & $0,00 E+00$ & $3,00 E+04$ \\
\hline & Sulfeto de Hidrogênio (H2S) & $g$ & $4,74 E+04$ & $0,00 E+00$ & $0,00 E+00$ & $0,00 E+00$ & $0,00 E+00$ & $4,74 E+04$ \\
\hline & Chumbo (Pb) & $g$ & $2,10 E+03$ & $0,00 E+00$ & $0,00 E+00$ & $0,00 E+00$ & $0,00 E+00$ & $2,10 E+03$ \\
\hline & Mercúrio (Hg) & $g$ & $3,97 E+01$ & $0,00 E+00$ & $0,00 E+00$ & $0,00 E+00$ & $0,00 E+00$ & $3,97 E+01$ \\
\hline
\end{tabular}




\begin{tabular}{|c|c|c|c|c|c|c|c|c|}
\hline & & Unidade & $\begin{array}{c}\text { Produção Aço } \\
\text { Carbono }\end{array}$ & $\begin{array}{l}\text { Produção } \\
\text { Tubos }\end{array}$ & $\begin{array}{c}\text { Instalação } \\
\text { Tubos }\end{array}$ & $\begin{array}{c}\text { Limpeza } \\
\text { Tubos }\end{array}$ & $\begin{array}{l}\text { Transporte } \\
\text { Tubos }\end{array}$ & $\begin{array}{c}\text { Total } \\
\text { Consolidado }\end{array}$ \\
\hline & \multicolumn{8}{|l|}{ Emissões Aéreas } \\
\hline & Metano $(\mathrm{CH} 4)$ & g & $3,00 E+05$ & $0,00 E+00$ & $0,00 E+00$ & $0,00 E+00$ & $0,00 E+00$ & $3,00 E+05$ \\
\hline & Óxido Nitroso (N2O) & g & $7,18 \mathrm{E}+04$ & $0,00 E+00$ & $0,00 E+00$ & $0,00 E+00$ & $0,00 E+00$ & $7,18 \mathrm{E}+04$ \\
\hline & VOC (exceto metano) & g & $8,16 \mathrm{E}+04$ & $0,00 E+00$ & $0,00 E+00$ & $0,00 E+00$ & $0,00 E+00$ & $8,16 E+04$ \\
\hline & Zinco (Zn) & g & $2,10 E+03$ & $0,00 E+00$ & $0,00 E+00$ & $0,00 \mathrm{E}+00$ & $0,00 E+00$ & $2,10 E+03$ \\
\hline & \multicolumn{8}{|l|}{ Emissões Aquosas } \\
\hline & Amônia (NH4+, NH3, as N) & g & $6,15 E+04$ & $0,00 E+00$ & $0,00 E+00$ & $0,00 \mathrm{E}+00$ & $0,00 E+00$ & $6,15 E+04$ \\
\hline & Cádmio $(\mathrm{Cd}++)$ & g & $4,57 E+01$ & $0,00 E+00$ & $0,00 E+00$ & $0,00 \mathrm{E}+00$ & $0,00 E+00$ & $4,57 E+01$ \\
\hline & Cromo (Cr III, Cr VI) & g & $5,19 E+01$ & $0,00 E+00$ & $0,00 E+00$ & $0,00 E+00$ & $0,00 E+00$ & $5,19 E+01$ \\
\hline & DQO (Demanda Química Oxigênio) & g & $1,30 E+02$ & $0,00 E+00$ & $0,00 E+00$ & $0,00 E+00$ & $0,00 E+00$ & $1,30 E+05$ \\
\hline & Ferro $(\mathrm{Fe}++, \mathrm{Fe} 3+)$ & g & $1,09 E+04$ & $0,00 E+00$ & $0,00 E+00$ & $0,00 E+00$ & $0,00 E+00$ & $1,09 E+04$ \\
\hline & Chumbo(Pb++, $\mathrm{Pb} 4+)$ & g & $-2,60 \mathrm{E}-01$ & $0,00 E+00$ & $0,00 E+00$ & $0,00 \mathrm{E}+00$ & $0,00 E+00$ & '-2,60E - 02 \\
\hline & Níquel (Ni++, Ni3+) & g & $1,79 E+02$ & $0,00 E+00$ & $0,00 E+00$ & $0,00 E+00$ & $0,00 E+00$ & $1,79 E+02$ \\
\hline & Compostos Nitrogenados (como N) & g & $1,43 E+04$ & $0,00 E+00$ & $0,00 E+00$ & $0,00 \mathrm{E}+00$ & $0,00 \mathrm{E}+00$ & $1,43 E+04$ \\
\hline & Compostos Fosforados (como P) & g & $1,20 \mathrm{E}+03$ & $0,00 E+00$ & $0,00 E+00$ & $0,00 E+00$ & $0,00 \mathrm{E}+00$ & $1,20 \mathrm{E}+03$ \\
\hline & Zinco $(Z n++)$ & g & $1,08 \mathrm{E}+03$ & $0,00 E+00$ & $0,00 E+00$ & $0,00 E+00$ & $0,00 E+00$ & $1,08 E+03$ \\
\hline & Materiais Suspensos & g & $1,08 \mathrm{E}+05$ & $0,00 E+00$ & $0,00 E+00$ & $0,00 E+00$ & $0,00 E+00$ & $1,08 \mathrm{E}+05$ \\
\hline \multicolumn{9}{|c|}{ Resíduos Sólidos } \\
\hline & Resíduo (total) & $\mathrm{kg}$ & $9,56 \mathrm{E}+05$ & $0,00 E+00$ & $0,00 E+00$ & $0,00 \mathrm{E}+00$ & $0,00 E+00$ & $9,56 \mathrm{E}+05$ \\
\hline & Sub-produtos não alocados & $\mathrm{Kg}$ & $4,10 E+04$ & $0,00 E+00$ & $0,00 E+00$ & $0,00 \mathrm{E}+00$ & $0,00 E+00$ & $4.10 E+04$ \\
\hline \multirow[t]{7}{*}{ Indicadores } & Indicadores de Energia & & & & & & & \\
\hline & Energia de "estoque" & MJ & $-2,65 E+05$ & $0,00 E+00$ & $0,00 E+00$ & $0,00 E+00$ & $0,00 E+00$ & $-2,65 E+05$ \\
\hline & Energia de combustível & MJ & $1,51 E+07$ & $7,03 E+05$ & $0,00 E+00$ & $0,00 E+00$ & $3,43 E+05$ & $1,62 E+07$ \\
\hline & Energia Renovável & MJ & $1,50 E+05$ & $1,67 E+05$ & $1,03 E+05$ & $2,46 \mathrm{E}+05$ & $0,00 E+00$ & $6,66 \mathrm{E}+05$ \\
\hline & Energia não Renovável & MJ & $1,46 \mathrm{E}+07$ & $7,03 E+05$ & $0,00 E+00$ & $0,00 E+00$ & $3,43 E+05$ & $1,64 E+07$ \\
\hline & Energia Elétrica & MJ & $0,00 E+00$ & $1,67 \mathrm{E}+05$ & $1,03 E+05$ & $2,46 \mathrm{E}+05$ & $0,00 E+00$ & $5,16 \mathrm{E}+05$ \\
\hline & Energia Primária Total & $\mathrm{MJ}$ & $1,48 \mathrm{E}+07$ & $8,70 \mathrm{E}+05$ & $1,03 E+05$ & $2,46 \mathrm{E}+05$ & $3,43 E+05$ & $1,64 \mathrm{E}+07$ \\
\hline
\end{tabular}


Apêndice D - Inventário do Ciclo de Vida do Sistema de Produto de Tubos em Aço Inoxidável 304, com 1,20 mm de espessura

\begin{tabular}{|c|c|c|c|c|c|c|c|c|}
\hline & & & & & SUB-SI & MAS & & \\
\hline & Aspectos Ambientai & & Produção & Produção & Instalação & Limpeza & Transporte & Total \\
\hline Entradas: & Matérias-primas & Unidade & Aço 304 & Tubos & Tubos & Tubos & Tubos & Consolidado \\
\hline & Minério de Cromo & $\mathrm{kg}$ & $8,73 E+03$ & $0,00 E+00$ & $0,00 E+00$ & $0,00 E+00$ & $0,00 E+00$ & $8,73 E+03$ \\
\hline & Carvão Mineral & $\mathrm{kg}$ & $5,63 E+04$ & $0,00 E+00$ & $0,00 E+00$ & $0,00 E+00$ & $0,00 E+00$ & $5,63 E+04$ \\
\hline & Dolomita & $\mathrm{kg}$ & $2,46 E+03$ & $0,00 E+00$ & $0,00 E+00$ & $0,00 E+00$ & $0,00 E+00$ & $2,46 \mathrm{E}+03$ \\
\hline & Minério de Ferro & $\mathrm{kg}$ & $1,38 \mathrm{E}+04$ & $0,00 E+00$ & $0,00 E+00$ & $0,00 E+00$ & $0,00 \mathrm{E}+00$ & $1,38 \mathrm{E}+04$ \\
\hline & Lignita & $\mathrm{kg}$ & $2,92 E+03$ & $0,00 E+00$ & $0,00 E+00$ & $0,00 E+00$ & $0,00 E+00$ & $2,92 E+03$ \\
\hline & Calcita & $\mathrm{kg}$ & $1,05 E+04$ & $0,00 E+00$ & $0,00 E+00$ & $0,00 E+00$ & $0,00 E+00$ & $1,05 E+04$ \\
\hline & Minério de Manganês & $\mathrm{kg}$ & $9,51 E+02$ & $0,00 E+00$ & $0,00 E+00$ & $0,00 E+00$ & $0,00 E+00$ & $9,51 E+02$ \\
\hline & Minério de Molibdênio & $\mathrm{kg}$ & $5,48 \mathrm{E}+01$ & $0,00 E+00$ & $0,00 E+00$ & $0,00 E+00$ & $0,00 \mathrm{E}+00$ & $5,48 \mathrm{E}+01$ \\
\hline & Gás Natural & $\mathrm{kg}$ & $1,33 E+04$ & $1,12 E+03$ & $0,00 E+00$ & $0,00 E+00$ & $0,00 E+00$ & $1,44 E+04$ \\
\hline & Óleo (bruto) & $\mathrm{kg}$ & $1,08 E+04$ & $0,00 E+00$ & $0,00 E+00$ & $0,00 E+00$ & $0,00 E+00$ & $1,08 E+04$ \\
\hline & Óleo Diesel & $\mathrm{kg}$ & $0,00 E+00$ & $0,00 E+00$ & $0,00 E+00$ & $0,00 E+00$ & $1,32 E+03$ & $1,32 E+03$ \\
\hline & Ferro-ligas & & & & & & & \\
\hline & $\mathrm{Fe}-\mathrm{Cr}$ & $\mathrm{kg}$ & $0,00 E+00$ & $0,00 E+00$ & $0,00 E+00$ & $0,00 E+00$ & $0,00 E+00$ & $0,00 E+00$ \\
\hline & $\mathrm{Fe}-\mathrm{Ni}$ & $\mathrm{kg}$ & $0,00 E+00$ & $0,00 E+00$ & $0,00 E+00$ & $0,00 E+00$ & $0,00 E+00$ & $0,00 E+00$ \\
\hline & Fe-Ti & $\mathrm{kg}$ & $0,00 E+00$ & $0,00 E+00$ & $0,00 E+00$ & $0,00 E+00$ & $0,00 E+00$ & $0,00 E+00$ \\
\hline & Fe-Nb & $\mathrm{kg}$ & $0,00 E+00$ & $0,00 E+00$ & $0,00 E+00$ & $0,00 E+00$ & $0,00 E+00$ & $0,00 E+00$ \\
\hline & Fe-Mo & $\mathrm{kg}$ & $0,00 E+00$ & $0,00 E+00$ & $0,00 E+00$ & $0,00 E+00$ & $0,00 E+00$ & $0,00 E+00$ \\
\hline & Sucatas & & & & & & & \\
\hline & 304 & $\mathrm{~kg}$ & $2,29 E+04$ & $0,00 E+00$ & $0,00 E+00$ & $0,00 E+00$ & $0,00 E+00$ & $2,29 E+04$ \\
\hline & 316 & $\mathrm{~kg}$ & $1,27 E+03$ & $0,00 E+00$ & $0,00 E+00$ & $0,00 E+00$ & $0,00 E+00$ & $1,27 E+03$ \\
\hline & 409 & $\mathrm{~kg}$ & $7,62 E+02$ & $0,00 E+00$ & $0,00 E+00$ & $0,00 E+00$ & $0,00 E+00$ & $7,62 E+02$ \\
\hline & 430 & $\mathrm{~kg}$ & $9,56 E+02$ & $0,00 E+00$ & $0,00 E+00$ & $0,00 E+00$ & $0,00 E+00$ & $\begin{array}{r}9,56 \mathrm{E}+02 \\
\text { Continua }\end{array}$ \\
\hline
\end{tabular}




\begin{tabular}{|c|c|c|c|c|c|c|c|}
\hline Matérias-primas & Unidade & \begin{tabular}{|c}
$\begin{array}{c}\text { Produção Aço } \\
304\end{array}$ \\
\end{tabular} & $\begin{array}{c}\text { Produção } \\
\text { Tubos }\end{array}$ & $\begin{array}{c}\text { Instalação } \\
\text { Tubos }\end{array}$ & $\begin{array}{c}\text { Limpeza } \\
\text { Tubos }\end{array}$ & $\begin{array}{c}\text { Transporte } \\
\text { Tubos }\end{array}$ & $\begin{array}{c}\text { Total } \\
\text { Consolidado } \\
\end{array}$ \\
\hline \multicolumn{8}{|l|}{ Sucatas } \\
\hline Outros Aços & $\mathrm{kg}$ & $1,87 E+03$ & $0,00 E+00$ & $0,00 E+00$ & $0,00 E+00$ & $0,00 E+00$ & $1,87 E+03$ \\
\hline Aço Carbono & $\mathrm{kg}$ & $1,08 \mathrm{E}+04$ & $0,00 E+00$ & $0,00 \mathrm{E}+00$ & $0,00 E+00$ & $0,00 E+00$ & $1,08 \mathrm{E}+04$ \\
\hline \multicolumn{8}{|c|}{ Água de alimentação (Volume) } \\
\hline Água de Processo (resfriamento, total) & litros & $3,13 E+06$ & $0,00 E+00$ & $0,00 E+00$ & $0,00 E+00$ & $0,00 E+00$ & $3,13 E+06$ \\
\hline Água Usada (total) & litros & $8,81 E+05$ & $0,00 E+00$ & $0,00 \mathrm{E}+00$ & $3,24 \mathrm{E}+07$ & $0,00 E+00$ & $3,33 \mathrm{E}+07$ \\
\hline \multicolumn{8}{|l|}{ Emissões Aéreas } \\
\hline Dióxido de Carbono (CO2) & $g$ & $3,04 \mathrm{E}+08$ & $3,03 E+06$ & $0,00 \mathrm{E}+00$ & $0,00 E+00$ & $3,59 E+06$ & $3,11 E+08$ \\
\hline Monóxido de Carbono (CO) & $g$ & $5,00 E+05$ & $0,00 E+00$ & $0,00 E+00$ & $0,00 E+00$ & $0,00 E+00$ & $5,00 E+05$ \\
\hline Cromo (Cr III, Cr VI) & g & $4,58 E+03$ & $0,00 E+00$ & $0,00 E+00$ & $0,00 E+00$ & $0,00 E+00$ & $4,58 \mathrm{E}+03$ \\
\hline Cromo (Cr. VI) & $g$ & $4,98 \mathrm{E}+00$ & $0,00 E+00$ & $0,00 \mathrm{E}+00$ & $0,00 E+00$ & $0,00 E+00$ & $4,98 \mathrm{E}+00$ \\
\hline Dioxinas (inespecificada) & $g$ & $4,48 \mathrm{E}-04$ & $0,00 E+00$ & $0,00 E+00$ & $0,00 E+00$ & $0,00 E+00$ & $4,48 \mathrm{E}-04$ \\
\hline Molibdênio (Mo, minério) & $g$ & $2,69 E+02$ & $0,00 E+00$ & $0,00 \mathrm{E}+00$ & $0,00 E+00$ & $0,00 E+00$ & $2,69 E+02$ \\
\hline Níquel & g & $3,88 E+03$ & $0,00 E+00$ & $0,00 E+00$ & $0,00 E+00$ & $0,00 E+00$ & $3,88 \mathrm{E}+03$ \\
\hline Óxidos de Nitrogênio (NOx como NO2) & g & $7,08 \mathrm{E}+05$ & $7,40 E+04$ & $0,00 E+00$ & $0,00 E+00$ & $2,22 E+02$ & $7,82 E+05$ \\
\hline Materiais Particulados (inespecificado) & $g$ & $3,45 E+05$ & $0,00 E+00$ & $0,00 E+00$ & $0,00 E+00$ & $0,00 E+00$ & $3,45 E+05$ \\
\hline Óxidos de Enxofre (SOx como SO2) & g & $2,31 E+06$ & $1,04 \mathrm{E}+02$ & $0,00 \mathrm{E}+00$ & $0,00 E+00$ & $4,95 E+03$ & $2,31 E+06$ \\
\hline \multicolumn{8}{|l|}{ Emissões Aquosas } \\
\hline Ácidos $(\mathrm{H}+)$ & $g$ & $4,16 \mathrm{E}+03$ & $0,00 E+00$ & $0,00 E+00$ & $0,00 E+00$ & $0,00 E+00$ & $4,16 \mathrm{E}+03$ \\
\hline Alumínio (Al3+) & $g$ & $1,13 E+03$ & $0,00 E+00$ & $0,00 E+00$ & $0,00 E+00$ & $0,00 E+00$ & $1,13 E+03$ \\
\hline Amônia (NH4+, NH3, as N) & $g$ & $5,18 \mathrm{E}+03$ & $0,00 E+00$ & $0,00 E+00$ & $0,00 E+00$ & $0,00 E+00$ & $5,18 E+03$ \\
\hline Cádmio $(\mathrm{Cd}++)$ & g & $9,96 \mathrm{E}+00$ & $0,00 E+00$ & $0,00 E+00$ & $0,00 E+00$ & $0,00 E+00$ & $9,96 \mathrm{E}+00$ \\
\hline Cloretos (Cl-) & g & $3,43 E+05$ & $0,00 E+00$ & $0,00 E+00$ & $0,00 E+00$ & $0,00 E+00$ & $3,43 E+05$ \\
\hline Cromo (Cr III, Cr VI) & $g$ & $5,58 E+02$ & $0,00 E+00$ & $0,00 E+00$ & $0,00 E+00$ & $0,00 E+00$ & $5,58 E+02$ \\
\hline Cromo (Cr VI) & g & $4,03 E+02$ & $0,00 E+00$ & $0,00 E+00$ & $0,00 E+00$ & $0,00 E+00$ & $4,03 E+02$ \\
\hline DQO (Demanda Química Oxigenio) & $g$ & $8,75 E+04$ & $0,00 E+00$ & $0,00 \mathrm{E}+00$ & $0,00 E+00$ & $0,00 E+00$ & $8,75 E+04$ \\
\hline Cobre $(\mathrm{Cu}+, \mathrm{Cu}++)$ & g & $2,99 E+01$ & $0,00 E+00$ & $0,00 E+00$ & $0,00 E+00$ & $0,00 E+00$ & $2,99 E+01$ \\
\hline
\end{tabular}




\begin{tabular}{|c|c|c|c|c|c|c|c|c|}
\hline & & Unidade & $\begin{array}{c}\text { Produção Aço } \\
304\end{array}$ & $\begin{array}{c}\text { Produção } \\
\text { Tubos } \\
\end{array}$ & $\begin{array}{c}\text { Instalação } \\
\text { Tubos } \\
\end{array}$ & $\begin{array}{c}\text { Limpeza } \\
\text { Tubos } \\
\end{array}$ & $\begin{array}{c}\text { Transporte } \\
\text { Tubos }\end{array}$ & $\begin{array}{c}\text { Total } \\
\text { Consolidado } \\
\end{array}$ \\
\hline & \multicolumn{8}{|l|}{ Emissões Aquosas } \\
\hline & Fluoretos (F-) & $g$ & $6,26 \mathrm{E}+03$ & $0,00 E+00$ & $0,00 E+00$ & $0,00 E+00$ & $0,00 E+00$ & $6,26 \mathrm{E}+03$ \\
\hline & Hidrocarbonetos (inespecificados) & g & $3,26 \mathrm{E}+03$ & $0,00 E+00$ & $0,00 E+00$ & $0,00 E+00$ & $0,00 E+00$ & $3,26 \mathrm{E}+03$ \\
\hline & Ferro $(\mathrm{Fe}++, \mathrm{Fe} 3+)$ & g & $7,32 \mathrm{E}+03$ & $0,00 E+00$ & $0,00 E+00$ & $0,00 E+00$ & $0,00 E+00$ & $7,32 E+03$ \\
\hline & Chumbo(Pb++, $\mathrm{Pb} 4+)$ & $\mathrm{g}$ & $9,46 \mathrm{E}+01$ & $0,00 E+00$ & $0,00 E+00$ & $0,00 E+00$ & $0,00 E+00$ & $9,46 \mathrm{E}+01$ \\
\hline & Manganês (Mn II, Mn IV, Mn VII) & g & $3,34 \mathrm{E}+02$ & $0,00 \mathrm{E}+00$ & $0,00 E+00$ & $0,00 E+00$ & $0,00 E+00$ & $3,34 \mathrm{E}+02$ \\
\hline & Molibdênio (Mo II, Mo III, Mo IV, Mo V, Mo VI) & g & $1,25 E+02$ & $0,00 E+00$ & $0,00 E+00$ & $0,00 E+00$ & $0,00 E+00$ & $1,25 E+02$ \\
\hline & Níquel (Ni++, $\mathrm{Ni3+}$ ) & g & $4,23 E+02$ & $0,00 E+00$ & $0,00 E+00$ & $0,00 E+00$ & $0,00 E+00$ & $4,23 E+02$ \\
\hline & Nitrato (NO3-) & g & $1,62 \mathrm{E}+05$ & $0,00 E+00$ & $0,00 E+00$ & $0,00 E+00$ & $0,00 E+00$ & $1,62 E+05$ \\
\hline & Compostos Nitrogenados (como N) & g & $1,99 E+05$ & $0,00 E+00$ & $0,00 E+00$ & $0,00 E+00$ & $0,00 E+00$ & $1,99 E+05$ \\
\hline & Compostos Fosforados (como P) & $\mathrm{g}$ & $2,34 \mathrm{E}+02$ & $0,00 E+00$ & $0,00 E+00$ & $0,00 E+00$ & $0,00 E+00$ & $2,34 \mathrm{E}+02$ \\
\hline & Dióxido de Silício (SiO2) & g & $1,81 E+04$ & $0,00 E+00$ & $0,00 E+00$ & $0,00 E+00$ & $0,00 E+00$ & $1,81 E+04$ \\
\hline & Compostos Sulfurados (como S) & g & $7,46 \mathrm{E}+04$ & $0,00 E+00$ & $0,00 E+00$ & $0,00 E+00$ & $0,00 E+00$ & $7,46 \mathrm{E}+04$ \\
\hline & Estanho $(\mathrm{Sn++}, \mathrm{Sn} 4+)$ & g & $1,49 E+01$ & $0,00 E+00$ & $0,00 E+00$ & $0,00 E+00$ & $0,00 E+00$ & $1,49 E+01$ \\
\hline & Zinco $(Z n++)$ & $g$ & $1,74 \mathrm{E}+02$ & $0,00 E+00$ & $0,00 E+00$ & $0,00 E+00$ & $0,00 E+00$ & $1,74 \mathrm{E}+02$ \\
\hline & Materiais Suspensos & G & $1,95 E+03$ & $0,00 E+00$ & $0,00 E+00$ & $0,00 E+00$ & $0,00 E+00$ & $1,95 E+03$ \\
\hline & \multicolumn{8}{|l|}{ Resíduos Sólidos } \\
\hline & Resíduo (total) & $\mathrm{kg}$ & $1,67 E+05$ & $0,00 E+00$ & $0,00 E+00$ & $0,00 E+00$ & $0,00 E+00$ & $1,67 E+05$ \\
\hline & Resíduo proveniente da produção de aço (total) & $\mathrm{Kg}$ & $8,42 E+03$ & $0,00 E+00$ & $0,00 E+00$ & $0,00 E+00$ & $0,00 E+00$ & $8,42 E+03$ \\
\hline \multirow[t]{7}{*}{ Indicadores } & Indicadores de Energia & & & & & & & \\
\hline & Energia de "estoque" & MJ & $2,03 E+05$ & $0,00 E+00$ & $0,00 E+00$ & $0,00 E+00$ & $0,00 E+00$ & $2,03 E+05$ \\
\hline & Energia de combustível & MJ & $2,49 E+06$ & $6,47 E+04$ & $0,00 E+00$ & $0,00 E+00$ & $5,16 \mathrm{E}+04$ & $2,60 \mathrm{E}+06$ \\
\hline & Energia Renovável & MJ & $1,26 \mathrm{E}+05$ & $1,54 \mathrm{E}+04$ & $8,22 E+04$ & $1,51 E+05$ & $0,00 E+00$ & $3,75 E+05$ \\
\hline & Energia não Renovável & MJ & $2,56 \mathrm{E}+06$ & $6,47 E+04$ & $0,00 \mathrm{E}+00$ & $0,00 E+00$ & $5,16 \mathrm{E}+04$ & $2,68 \mathrm{E}+06$ \\
\hline & Energia Elétrica & MJ & $4,71 E+05$ & $1,54 \mathrm{E}+04$ & $8,22 E+04$ & $1,51 E+05$ & $0,00+00$ & $7,20 \mathrm{E}+05$ \\
\hline & Energia Primária Total & $\mathrm{MJ}$ & $2,69 \mathrm{E}+06$ & $8,01 \mathrm{E}+04$ & $8,22 \mathrm{E}+04$ & $1,51 \mathrm{E}+05$ & $5,16 \mathrm{E}+04$ & $3,06 \mathrm{E}+06$ \\
\hline
\end{tabular}


Apêndice E - Inventário do Ciclo de Vida do Sistema de Produto de Tubos em Aço Inoxidável 304, com 1,50 mm de espessura

\begin{tabular}{|c|c|c|c|c|c|c|c|c|}
\hline \multirow{4}{*}{ Entradas: } & \multirow{2}{*}{\multicolumn{2}{|c|}{ Aspectos Ambientais }} & \multicolumn{6}{|c|}{ SUB-SISTEMAS } \\
\hline & & & \multirow{2}{*}{$\begin{array}{c}\text { Produção } \\
\text { Aço } 304\end{array}$} & \multirow{2}{*}{$\begin{array}{c}\text { Produção } \\
\text { Tubos } \\
\end{array}$} & \multirow{2}{*}{$\begin{array}{c}\text { Instalação } \\
\text { Tubos } \\
\end{array}$} & \multirow{2}{*}{$\begin{array}{c}\text { Limpeza } \\
\text { Tubos } \\
\end{array}$} & \multirow{2}{*}{$\begin{array}{c}\text { Transporte } \\
\text { Tubos } \\
\end{array}$} & \multirow{2}{*}{$\begin{array}{c}\text { Total } \\
\text { Consolidado } \\
\end{array}$} \\
\hline & Matérias-primas & Unidade & & & & & & \\
\hline & Minério de Cromo & $\mathrm{kg}$ & $1,10 E+04$ & $0,00 E+00$ & $0,00 E+00$ & $0,00 E+00$ & $0,00 E+00$ & $1,10 E+04$ \\
\hline & Carvão Mineral & $\mathrm{kg}$ & $7,08 \mathrm{E}+04$ & $0,00 E+00$ & $0,00 E+00$ & $0,00 E+00$ & $0,00 E+00$ & $7,08 E+04$ \\
\hline & Dolomita & $\mathrm{kg}$ & $3,10 E+03$ & $0,00 E+00$ & $0,00 E+00$ & $0,00 E+00$ & $0,00 E+00$ & $3,10 E+03$ \\
\hline & Minério de Ferro & $\mathrm{kg}$ & $1,74 \mathrm{E}+04$ & $0,00 E+00$ & $0,00 E+00$ & $0,00 E+00$ & $0,00 E+00$ & $1,74 E+04$ \\
\hline & Lignita & $\mathrm{kg}$ & $3,68 E+03$ & $0,00 E+00$ & $0,00 E+00$ & $0,00 E+00$ & $0,00 E+00$ & $3,68 E+03$ \\
\hline & Calcita & $\mathrm{kg}$ & $1,32 E+04$ & $0,00 E+00$ & $0,00 E+00$ & $0,00 E+00$ & $0,00 E+00$ & $1,32 E+04$ \\
\hline & Minério de Manganês & $\mathrm{kg}$ & $1,98 E+03$ & $0,00 E+00$ & $0,00 E+00$ & $0,00 E+00$ & $0,00 E+00$ & $1,98 \mathrm{E}+03$ \\
\hline & Minério de Molibdênio & $\mathrm{kg}$ & $6,90 E+01$ & $0,00 E+00$ & $0,00 E+00$ & $0,00 E+00$ & $0,00 E+00$ & $6,90 E+01$ \\
\hline & Gás Natural & $\mathrm{kg}$ & $1,67 E+04$ & $1,41 E+03$ & $0,00 E+00$ & $0,00 E+00$ & $0,00 E+00$ & $1,81 E+04$ \\
\hline & Minério de Níquel & $\mathrm{kg}$ & $3,63 E+03$ & $0,00 E+00$ & $0,00 E+00$ & $0,00 E+00$ & $0,00 E+00$ & $3,63 E+03$ \\
\hline & Óleo (bruto) & $\mathrm{kg}$ & $1,36 \mathrm{E}+04$ & $0,00 E+00$ & $0,00 E+00$ & $0,00 E+00$ & $0,00 E+00$ & $1,36 \mathrm{E}+04$ \\
\hline & Óleo Diesel & $\mathrm{kg}$ & $0,00 E+00$ & $0,00 E+00$ & $0,00 E+00$ & $0,00 E+00$ & $1,67 E+03$ & $1,67 E+03$ \\
\hline \multicolumn{9}{|c|}{ Ferro-ligas } \\
\hline & $\mathrm{Fe}-\mathrm{Cr}$ & $\mathrm{kg}$ & $0,00 E+00$ & $0,00 E+00$ & $0,00 E+00$ & $0,00 E+00$ & $0,00 E+00$ & $0,00 E+00$ \\
\hline & $\mathrm{Fe}-\mathrm{Ni}$ & $\mathrm{kg}$ & $0,00 E+00$ & $0,00 E+00$ & $0,00 E+00$ & $0,00 E+00$ & $0,00 E+00$ & $0,00 E+00$ \\
\hline & Fe-Tí & $\mathrm{kg}$ & $0,00 E+00$ & $0,00 E+00$ & $0,00 E+00$ & $0,00 E+00$ & $0,00 E+00$ & $0,00 E+00$ \\
\hline & $\mathrm{Fe}-\mathrm{Nb}$ & $\mathrm{kg}$ & $0,00 E+00$ & $0,00 E+00$ & $0,00 E+00$ & $0,00 E+00$ & $0,00 E+00$ & $0,00 E+00$ \\
\hline & Fe-Mo & $\mathrm{kg}$ & $0,00 E+00$ & $0,00 E+00$ & $0,00 E+00$ & $0,00 E+00$ & $0,00 E+00$ & $0,00 E+00$ \\
\hline \multicolumn{9}{|c|}{ Sucatas } \\
\hline & 304 & $\mathrm{~kg}$ & $2,88 E+04$ & $0,00 E+00$ & $0,00 \mathrm{E}+00$ & $0,00 E+00$ & $0,00 E+00$ & $2,88 \mathrm{E}+04$ \\
\hline & 316 & $\mathrm{~kg}$ & $1,59 E+03$ & $0,00 E+00$ & $0,00 E+00$ & $0,00 E+00$ & $0,00 E+00$ & $1,59 E+03$ \\
\hline & 409 & $\mathrm{~kg}$ & $9,59 E+02$ & $0,00 E+00$ & $0,00 E+00$ & $0,00 E+00$ & $0,00 E+00$ & $9,59 E+02$ \\
\hline & 430 & $\mathrm{~kg}$ & $1,20 \mathrm{E}+03$ & $0,00 E+00$ & $0,00 E+00$ & $0,00 E+00$ & $0,00 E+00$ & $\begin{array}{c}1,20 E+03 \\
\text { Continua }\end{array}$ \\
\hline
\end{tabular}




\begin{tabular}{|c|c|c|c|c|c|c|c|}
\hline Matérias-primas & Unidade & $\begin{array}{c}\text { Produção Aço } \\
304 \\
\end{array}$ & $\begin{array}{c}\text { Produção } \\
\text { Tubos }\end{array}$ & $\begin{array}{c}\text { Instalação } \\
\text { Tubos }\end{array}$ & $\begin{array}{c}\text { Limpeza } \\
\text { Tubos }\end{array}$ & $\begin{array}{c}\text { Transporte } \\
\text { Tubos }\end{array}$ & $\begin{array}{c}\text { Total } \\
\text { Consolidado } \\
\end{array}$ \\
\hline \multicolumn{8}{|l|}{ Sucatas } \\
\hline Outros Aços & $\mathrm{kg}$ & $2,35 E+03$ & $0,00 E+00$ & $0,00 E+00$ & $0,00 E+00$ & $0,00 E+00$ & $2,35 E+03$ \\
\hline Aço Carbono & $\mathrm{kg}$ & $1,37 E+04$ & $0,00 E+00$ & $0,00 E+00$ & $0,00 E+00$ & $0,00 E+00$ & $1,37 E+04$ \\
\hline \multicolumn{8}{|l|}{ Água de alimentação (Volume) } \\
\hline Água de Processo (resfriamento, total) & litros & $3,94 \mathrm{E}+06$ & $0,00 E+00$ & $0,00 E+00$ & $0,00 E+00$ & $0,00 \mathrm{E}+00$ & $3,94 \mathrm{E}+06$ \\
\hline Água Usada (total) & litros & $1,11 E+06$ & $0,00 E+00$ & $0,00 E+00$ & $3,29 E+07$ & $0,00 E+00$ & $3,40 E+07$ \\
\hline \multicolumn{8}{|l|}{ Emissões Aéreas } \\
\hline Dióxido de Carbono (CO2) & g & $3,82 E+08$ & $3,81 E+06$ & $0,00 E+00$ & $0,00 E+00$ & $4,52 E+06$ & $3,90 E+08$ \\
\hline Monóxido de Carbono (CO) & g & $6,30 E+05$ & $0,00 E+00$ & $0,00 E+00$ & $0,00 E+00$ & $0,00 E+00$ & $6,30 \mathrm{E}+05$ \\
\hline Cromo (Cr III, Cr VI) & g & $5,76 \mathrm{E}+03$ & $0,00 E+00$ & $0,00 E+00$ & $0,00 E+00$ & $0,00 \mathrm{E}+00$ & $5,76 \mathrm{E}+03$ \\
\hline Cromo (Cr. VI) & g & $6,27 E+00$ & $0,00 E+00$ & $0,00 E+00$ & $0,00 E+00$ & $0,00 E+00$ & $6,27 E+00$ \\
\hline Dioxinas (inespecificada) & g & $5,64 \mathrm{E}-04$ & $0,00 E+00$ & $0,00 E+00$ & $0,00 E+00$ & $0,00 E+00$ & $5,64 \mathrm{E}-0$ \\
\hline Molibdênio (Mo, minério) & g & $3,39 E+02$ & $0,00 E+00$ & $0,00 E+00$ & $0,00 E+00$ & $0,00 E+00$ & $3,39 E+02$ \\
\hline Níquel & g & $4,88 E+03$ & $0,00 E+00$ & $0,00 E+00$ & $0,00 E+00$ & $0,00 E+00$ & $4,88 \mathrm{E}+03$ \\
\hline Óxidos de Nitrogênio (NOx como NO2) & g & $8,91 E+05$ & $9,30 E+04$ & $0,00 E+00$ & $0,00 E+00$ & $2,79 \mathrm{E}+02$ & $9,84 E+05$ \\
\hline Materiais Particulados (inespecificado) & g & $4,35 E+05$ & $0,00 E+00$ & $0,00 E+00$ & $0,00 E+00$ & $0,00 E+00$ & $4,35 E+05$ \\
\hline Óxidos de Enxofre (SOx como SO2) & g & $2,91 E+06$ & $1,31 E+04$ & $0,00 E+00$ & $0,00 E+00$ & $6,23 E+03$ & $2,93 E+06$ \\
\hline \multicolumn{8}{|l|}{ Emissões Aquosas } \\
\hline Ácidos $(\mathrm{H}+)$ & g & $5,24 \mathrm{E}+03$ & $0,00 E+00$ & $0,00 E+00$ & $0,00 E+00$ & $0,00 E+00$ & $5,24 E+03$ \\
\hline Alumínio (Al3+) & $g$ & $1,42 E+03$ & $0,00 E+00$ & $0,00 E+00$ & $0,00 E+00$ & $0,00 E+00$ & $1,42 E+03$ \\
\hline Amônia $(\mathrm{NH} 4+, \mathrm{NH} 3$, as $\mathrm{N})$ & g & $6,52 E+03$ & $0,00 E+00$ & $0,00 E+00$ & $0,00 E+00$ & $0,00 \mathrm{E}+00$ & $6,52 E+03$ \\
\hline Cádmio $(\mathrm{Cd}++)$ & $g$ & $1,25 E+01$ & $0,00 E+00$ & $0,00 E+00$ & $0,00 E+00$ & $0,00 E+00$ & $1,25 E+01$ \\
\hline Cloretos (Cl-) & g & $4,32 E+05$ & $0,00 E+00$ & $0,00 E+00$ & $0,00 E+00$ & $0,00 \mathrm{E}+00$ & $4,32 E+05$ \\
\hline Cromo (Cr III, Cr VI) & g & $7,02 E+02$ & $0,00 E+00$ & $0,00 E+00$ & $0,00 E+00$ & $0,00 E+00$ & $7,02 E+02$ \\
\hline Cromo (Cr VI) & g & $5,08 \mathrm{E}+02$ & $0,00 E+00$ & $0,00 E+00$ & $0,00 E+00$ & $0,00 E+00$ & $5,08 \mathrm{E}+02$ \\
\hline DQO (Demanda Química Oxigênio) & g & $1,10 E+05$ & $0,00 E+00$ & $0,00 E+00$ & $0,00 E+00$ & $0,00 E+00$ & $1,10 E+05$ \\
\hline Cobre $(\mathrm{Cu}+, \mathrm{Cu}++)$ & g & $3,76 E+01$ & $0,00 E+00$ & $0,00 E+00$ & $0,00 E+00$ & $0,00 E+00$ & $3,76 \mathrm{E}+01$ \\
\hline
\end{tabular}




\begin{tabular}{|c|c|c|c|c|c|c|c|c|}
\hline & & Unidade & $\begin{array}{c}\text { Produção Aço } \\
304\end{array}$ & $\begin{array}{l}\text { Produção } \\
\text { Tubos }\end{array}$ & $\begin{array}{l}\text { Instalação } \\
\text { Tubos }\end{array}$ & $\begin{array}{c}\text { Limpeza } \\
\text { Tubos }\end{array}$ & $\begin{array}{c}\text { Transporte } \\
\text { Tubos }\end{array}$ & $\begin{array}{c}\text { Total } \\
\text { Consolidado } \\
\end{array}$ \\
\hline & \multicolumn{8}{|l|}{ Emissões Aquosas } \\
\hline & Fluoretos (F-) & g & $7,88 \mathrm{E}+03$ & $0,00 E+00$ & $0,00 E+00$ & $0,00 E+00$ & $0,00 E+00$ & $7,88 \mathrm{E}+03$ \\
\hline & Hidrocarbonetos (inespecificados) & g & $4,11 E+03$ & $0,00 E+00$ & $0,00 E+00$ & $0,00 E+00$ & $0,00 E+00$ & $4,11 E+03$ \\
\hline & Ferro $(\mathrm{Fe}++, \mathrm{Fe} 3+)$ & $g$ & $9,21 E+03$ & $0,00 E+00$ & $0,00 E+00$ & $0,00 E+00$ & $0,00 E+00$ & $9,21 E+03$ \\
\hline & Chumbo(Pb++, $\mathrm{Pb} 4+)$ & g & $9,21 E+03$ & $0,00 E+00$ & $0,00 \mathrm{E}+00$ & $0,00 E+00$ & $0,00 E+00$ & $9,21 E+03$ \\
\hline & Manganês (Mn II, Mn IV, Mn VII) & g & $4,20 E+02$ & $0,00 E+00$ & $0,00 E+00$ & $0,00 E+00$ & $0,00 E+00$ & $4,20 E+02$ \\
\hline & Molibdênio (Mo II, Mo III, Mo IV, Mo V, Mo VI) & g & $1,57 E+02$ & $0,00 E+00$ & $0,00 E+00$ & $0,00 E+00$ & $0,00 E+00$ & $1,57 E+02$ \\
\hline & Níquel (Ni++, $\mathrm{Ni3+}$ ) & g & $5,33 E+02$ & $0,00 E+00$ & $0,00 E+00$ & $0,00 E+00$ & $0,00 E+00$ & $5,33 E+02$ \\
\hline & Nitrato (NO3-) & g & $2,05 E+05$ & $0,00 E+00$ & $0,00 E+00$ & $0,00 E+00$ & $0,00 E+00$ & $2,05 E+05$ \\
\hline & Compostos Nitrogenados (como N) & g & $2,50 E+05$ & $0,00 E+00$ & $0,00 \mathrm{E}+00$ & $0,00 E+00$ & $0,00 E+00$ & $2,50 E+05$ \\
\hline & Compostos Fosforados (como P) & g & $2,95 E+02$ & $0,00 E+00$ & $0,00 E+00$ & $0,00 E+00$ & $0,00 E+00$ & $2,95 E+02$ \\
\hline & Dióxido de Silício (SiO2) & g & $2,28 E+04$ & $0,00 E+00$ & $0,00 E+00$ & $0,00 E+00$ & $0,00 E+00$ & $2,28 E+04$ \\
\hline & Compostos Sulfurados (como S) & g & $9,39 E+04$ & $0,00 E+00$ & $0,00 E+00$ & $0,00 E+00$ & $0,00 E+00$ & $9,39 E+04$ \\
\hline & Estanho $(\mathrm{Sn++}, \mathrm{Sn} 4+)$ & g & $1,88 E+01$ & $0,00 E+00$ & $0,00 E+00$ & $0,00 E+00$ & $0,00 E+00$ & $1,88 \mathrm{E}+01$ \\
\hline & Zinco $(Z n++)$ & g & $2,20 E+02$ & $0,00 E+00$ & $0,00 E+00$ & $0,00 E+00$ & $0,00 E+00$ & $2,20 E+02$ \\
\hline & Materiais Suspensos & $g$ & $2,46 E+03$ & $0,00 E+00$ & $0,00 E+00$ & $0,00 E+00$ & $0,00 E+00$ & $2,46 E+03$ \\
\hline \multicolumn{9}{|c|}{ Resíduos Sólidos } \\
\hline & Resíduo (total) & $\mathrm{kg}$ & $2,10 E+05$ & $0,00 E+00$ & $0,00 \mathrm{E}+00$ & $0,00 E+00$ & $0,00 E+00$ & $2,10 E+05$ \\
\hline & Resíduo proveniente da produção de aço (total) & $\mathrm{Kg}$ & $1,06 \mathrm{E}+04$ & $0,00 E+00$ & $0,00 E+00$ & $0,00 E+00$ & $0,00 E+00$ & $1,06 \mathrm{E}+04$ \\
\hline \multirow[t]{7}{*}{ Indicadores } & Indicadores de Energia & & & & & & & \\
\hline & Energia de "estoque" & MJ & $2,56 \mathrm{E}+05$ & $0,00 E+00$ & $0,00 E+00$ & $0,00 E+00$ & $0,00 E+00$ & $2,56 \mathrm{E}+05$ \\
\hline & Energia de combustível & MJ & $3,13 E+06$ & $8,14 \mathrm{E}+04$ & $0,00 E+00$ & $0,00 E+00$ & $6,50 \mathrm{E}+04$ & $3,28 E+06$ \\
\hline & Energia Renovável & MJ & $1,58 \mathrm{E}+05$ & $0,00 E+00$ & $0,00 E+00$ & $1,53 E+05$ & $0,00 E+00$ & $3,11 E+05$ \\
\hline & Energia não Renovável & MJ & $3,23 E+06$ & $8,14 \mathrm{E}+04$ & $0,00 E+00$ & $0,00 E+00$ & $6,50 \mathrm{E}+04$ & $3,38 E+06$ \\
\hline & Energia Elétrica & MJ & $5,93 E+05$ & $1,94 \mathrm{E}+04$ & $8,36 \mathrm{E}+04$ & $1,53 E+05$ & $0,00 E+00$ & $8,49 E+05$ \\
\hline & Energia Primária Total & $\mathrm{MJ}$ & $3,39 E+06$ & $1,01 \mathrm{E}+05$ & $8,36 \mathrm{E}+04$ & $1,53 \mathrm{E}+05$ & $6,50 \mathrm{E}+04$ & $3,79 E+06$ \\
\hline
\end{tabular}


Apêndice F - Inventário do Ciclo de Vida do Sistema de Produto de Tubos em Aço Inoxidável 444, com 1,20 mm de espessura

\begin{tabular}{|c|c|c|c|c|c|c|c|c|}
\hline & & & & & & & & \\
\hline & & & & & SUB-S & EMAS & & \\
\hline & Aspectos Ambienta & & Produção & Produção & Instalação & Limpeza & Transporte & Total \\
\hline Entradas: & Matérias-primas & Unidade & Aço 444 & Tubos & Tubos & Tubos & Tubos & Consolidado \\
\hline & Minério de Cromo & $\mathrm{kg}$ & $1,25 E+04$ & $0,00 E+00$ & $0,00 E+00$ & $0,00 E+00$ & $0,00 E+00$ & $1,25 E+04$ \\
\hline & Carvão Mineral & $\mathrm{kg}$ & $5,93 E+04$ & $0,00 E+00$ & $0,00 E+00$ & $0,00 E+00$ & $0,00 E+00$ & $5,93 E+04$ \\
\hline & Dolomita & $\mathrm{kg}$ & $2,42 E+03$ & $0,00 E+00$ & $0,00 E+00$ & $0,00 E+00$ & $0,00 E+00$ & $2,42 E+03$ \\
\hline & Minério de Ferro & $\mathrm{kg}$ & $8,65 E+03$ & $0,00 E+00$ & $0,00 E+00$ & $0,00 E+00$ & $0,00 E+00$ & $8,65 E+03$ \\
\hline & Lignita & $\mathrm{kg}$ & $2,26 \mathrm{E}+03$ & $0,00 E+00$ & $0,00 E+00$ & $0,00 E+00$ & $0,00 \mathrm{E}+00$ & $2,26 \mathrm{E}+03$ \\
\hline & Calcita & $\mathrm{kg}$ & $8,59 E+03$ & $0,00 E+00$ & $0,00 E+00$ & $0,00 E+00$ & $0,00 E+00$ & $8,59 E+03$ \\
\hline & Minério de Manganês & $\mathrm{kg}$ & $2,49 E+02$ & $0,00 E+00$ & $0,00 E+00$ & $0,00 E+00$ & $0,00 E+00$ & $2,49 E+02$ \\
\hline & Minério de Molibdênio & $\mathrm{kg}$ & $9,78 E+00$ & $0,00 E+00$ & $0,00 E+00$ & $0,00 E+00$ & $0,00 E+00$ & $9,78 E+00$ \\
\hline & Gás Natural & $\mathrm{kg}$ & $1,19 E+04$ & $1,10 E+03$ & $0,00 \mathrm{E}+00$ & $0,00 E+00$ & $0,00 \mathrm{E}+00$ & $1,30 E+04$ \\
\hline & Minério de Níquel & $\mathrm{kg}$ & $0,00 E+00$ & $0,00 E+00$ & $0,00 E+00$ & $0,00 E+00$ & $0,00 E+00$ & $0,00 E+00$ \\
\hline & Óleo (bruto) & $\mathrm{kg}$ & $4,67 E+03$ & $0,00 E+00$ & $0,00 E+00$ & $0,00 E+00$ & $0,00 E+00$ & $4,67 E+03$ \\
\hline & Óleo Diesel & $\mathrm{kg}$ & $0,00 E+00$ & $0,00 E+00$ & $0,00 E+00$ & $0,00 E+00$ & $1,30 \mathrm{E}+03$ & $1,30 E+03$ \\
\hline & Ferro-ligas & & & & & & & \\
\hline & $\mathrm{Fe}-\mathrm{Cr}$ & $\mathrm{kg}$ & $9,00 E+02$ & $0,00 E+00$ & $0,00 E+00$ & $0,00 E+00$ & $0,00 E+00$ & $9,00 E+02$ \\
\hline & $\mathrm{Fe}-\mathrm{Ni}$ & $\mathrm{kg}$ & $1,22 \mathrm{E}+03$ & $0,00 E+00$ & $0,00 E+00$ & $0,00 E+00$ & $0,00 E+00$ & $1,22 E+03$ \\
\hline & $\mathrm{Fe}-\mathrm{Ti}$ & $\mathrm{kg}$ & $5,23 E+02$ & $0,00 E+00$ & $0,00 E+00$ & $0,00 E+00$ & $0,00 E+00$ & $5,23 E+02$ \\
\hline & Fe-Nb & $\mathrm{kg}$ & $2,93 E+02$ & $0,00 E+00$ & $0,00 E+00$ & $0,00 E+00$ & $0,00 \mathrm{E}+00$ & $2,93 E+02$ \\
\hline & Fe-Mo & $\mathrm{kg}$ & $1,66 \mathrm{E}+03$ & $0,00 E+00$ & $0,00 E+00$ & $0,00 E+00$ & $0,00 E+00$ & $1,66 E+03$ \\
\hline & Sucatas & & & & & & & \\
\hline & 304 & $\mathrm{~kg}$ & $2,45 E+01$ & $0,00 E+00$ & $0,00 E+00$ & $0,00 E+00$ & $0,00 \mathrm{E}+00$ & $2,45 E+01$ \\
\hline & 316 & $\mathrm{~kg}$ & $0,00 E+00$ & $0,00 E+00$ & $0,00 E+00$ & $0,00 E+00$ & $0,00 E+00$ & $0,00 E+00$ \\
\hline & 409 & $\mathrm{~kg}$ & $6,10 E+03$ & $0,00 E+00$ & $0,00 E+00$ & $0,00 E+00$ & $0,00 E+00$ & $6,10 E+03$ \\
\hline & 430 & $\mathrm{~kg}$ & $4,75 E+03$ & $0,00 E+00$ & $0,00 E+00$ & $0,00 E+00$ & $0,00 E+00$ & $\begin{array}{c}4,75 E+03 \\
\text { Continua }\end{array}$ \\
\hline
\end{tabular}




\begin{tabular}{|c|c|c|c|c|c|c|c|}
\hline Matérias-primas & Unidade & \begin{tabular}{|c} 
Produção Aço \\
444
\end{tabular} & $\begin{array}{c}\text { Produção } \\
\text { Tubos }\end{array}$ & $\begin{array}{c}\text { Instalação } \\
\text { Tubos }\end{array}$ & $\begin{array}{c}\text { Limpeza } \\
\text { Tubos }\end{array}$ & $\begin{array}{c}\text { Transporte } \\
\text { Tubos }\end{array}$ & $\begin{array}{c}\text { Total } \\
\text { Consolidado } \\
\end{array}$ \\
\hline \multicolumn{8}{|l|}{ Sucatas } \\
\hline Outros Aços & $\mathrm{kg}$ & $1,43 E+03$ & $0,00 E+00$ & $0,00 \mathrm{E}+00$ & $0,00 E+00$ & $0,00 E+00$ & $1,43 E+03$ \\
\hline Aço Carbono & $\mathrm{kg}$ & $3,67 E+04$ & $0,00 E+00$ & $0,00 \mathrm{E}+00$ & & $0,00 E+00$ & $3,67 E+04$ \\
\hline \multicolumn{8}{|l|}{ Água de alimentação (Volume) } \\
\hline Água de Processo (resfriamento, total) & litros & $1,05 E+06$ & $0,00 E+00$ & $0,00 E+00$ & $0,00 E+00$ & $0,00 E+00$ & $1,05 E+06$ \\
\hline Água Usada (total) & litros & $9,83 E+05$ & $0,00 E+00$ & $0,00 E+00$ & $3,24 \mathrm{E}+07$ & $0,00 E+00$ & $3,34 \mathrm{E}+07$ \\
\hline \multicolumn{8}{|l|}{ Emissões Aéreas } \\
\hline Dióxido de Carbono (CO2) & $g$ & $2,62 E+08$ & $2,98 \mathrm{E}+06$ & $0,00 E+00$ & $0,00 E+00$ & $3,52 E+06$ & $2,65 E+08$ \\
\hline Monóxido de Carbono (CO) & $g$ & $3,95 E+05$ & $0,00 E+00$ & $0,00 E+00$ & $0,00 E+00$ & $0,00 E+00$ & $3,95 E+05$ \\
\hline Cromo (Cr III, Cr VI) & $g$ & $3,34 \mathrm{E}+03$ & $0,00 E+00$ & $0,00 E+00$ & $0,00 E+00$ & $0,00 E+00$ & $6,34 \mathrm{E}+03$ \\
\hline Cromo (Cr. VI) & $g$ & $1,03 E+01$ & $0,00 E+00$ & $0,00 E+00$ & $0,00 E+00$ & $0,00 E+00$ & $1,03 E+01$ \\
\hline Dioxinas (inespecificada) & g & 1,61E - 05 & $0,00 E+00$ & $0,00 E+00$ & $0,00 E+00$ & $0,00 E+00$ & $1,61 E-05$ \\
\hline Molibdênio (Mo, minério) & $g$ & $3,03 E+02$ & $0,00 E+00$ & $0,00 E+00$ & $0,00 E+00$ & $0,00 E+00$ & $3,03 E+02$ \\
\hline Níquel & g & $1,51 E+03$ & $0,00 E+00$ & $0,00 E+00$ & $0,00 E+00$ & $0,00 E+00$ & $1,51 E+03$ \\
\hline Óxidos de Nitrogênio (NOx como NO2) & g & $6,32 E+05$ & $7,26 \mathrm{E}+04$ & $0,00 E+00$ & $0,00 E+00$ & $2,18 \mathrm{E}+02$ & $7,05 E+05$ \\
\hline Materiais Particulados (inespecificado) & g & $2,79 E+05$ & $0,00 E+00$ & $0,00 E+00$ & $0,00 E+00$ & $0,00 E+00$ & $2,79 E+05$ \\
\hline Óxidos de Enxofre (SOx como SO2) & g & $1,11 E+06$ & $1,02 E+02$ & $0,00 E+00$ & $0,00 E+00$ & $4,88 E+03$ & $1,11 E+06$ \\
\hline \multicolumn{8}{|l|}{ Emissões Aquosas } \\
\hline Ácidos $(\mathrm{H}+)$ & $g$ & $4,18 E+03$ & $0,00 E+00$ & $0,00 E+00$ & $0,00 E+00$ & $0,00 E+00$ & $4,18 E+03$ \\
\hline Alumínio (Al3+) & $g$ & $1,25 E+03$ & $0,00 E+00$ & $0,00 E+00$ & $0,00 E+00$ & $0,00 E+00$ & $1,25 E+03$ \\
\hline Amônia (NH4+, NH3, as N) & $g$ & $5,07 E+03$ & $0,00 E+00$ & $0,00 E+00$ & $0,00 E+00$ & $0,00 E+00$ & $5,07 E+03$ \\
\hline Cádmio (Cd++) & $g$ & $9,78 \mathrm{E}+00$ & $0,00 E+00$ & $0,00 E+00$ & $0,00 E+00$ & $0,00 E+00$ & $9,78 E+00$ \\
\hline Cloretos (Cl-) & $g$ & $3,25 E+05$ & $0,00 E+00$ & $0,00 E+00$ & $0,00 E+00$ & $0,00 E+00$ & $3,25 E+05$ \\
\hline Cromo (Cr III, Cr VI) & $g$ & $6,06 E+02$ & $0,00 E+00$ & $0,00 E+00$ & $0,00 E+00$ & $0,00 E+00$ & $6,06 \mathrm{E}+02$ \\
\hline Cromo (Cr VI) & $g$ & $4,16 E+02$ & $0,00 E+00$ & $0,00 E+00$ & $0,00 E+00$ & $0,00 E+00$ & $4,16 E+02$ \\
\hline DQO (Demanda Química Oxigênio) & $g$ & $8,65 E+04$ & $0,00 E+00$ & $0,00 E+00$ & $0,00 E+00$ & $0,00 \mathrm{E}+00$ & $8,65 E+04$ \\
\hline Cobre $(\mathrm{Cu}+, \mathrm{Cu}++)$ & $g$ & $1,96 E+01$ & $0,00 E+00$ & $0,00 E+00$ & $0,00 E+00$ & $0,00 E+00$ & $1,96 \mathrm{E}+01$ \\
\hline
\end{tabular}




\begin{tabular}{|c|c|c|c|c|c|c|c|c|}
\hline & & Unidade & \begin{tabular}{|c|} 
Produção Aço \\
444
\end{tabular} & $\begin{array}{l}\text { Produção } \\
\text { Tubos }\end{array}$ & $\begin{array}{c}\text { Instalação } \\
\text { Tubos }\end{array}$ & $\begin{array}{c}\text { Limpeza } \\
\text { Tubos } \\
\end{array}$ & $\begin{array}{c}\text { Transporte } \\
\text { Tubos }\end{array}$ & $\begin{array}{c}\text { Total } \\
\text { Consolidado }\end{array}$ \\
\hline & \multicolumn{8}{|l|}{ Emissões Aquosas } \\
\hline & Fluoretos (F-) & g & $7,72 E+03$ & $0,00 E+00$ & $0,00 E+00$ & $0,00 E+00$ & $0,00 E+00$ & $7,72 E+03$ \\
\hline & Hidrocarbonetos (inespecificados) & g & $4,14 E+03$ & $0,00 E+00$ & $0,00 E+00$ & $0,00 E+00$ & $0,00 E+00$ & $4,14 \mathrm{E}+03$ \\
\hline & Ferro $(\mathrm{Fe}++, \mathrm{Fe} 3+)$ & g & $6,36 \mathrm{E}+03$ & $0,00 E+00$ & $0,00 E+00$ & $0,00 E+00$ & $0,00 E+00$ & $6,36 \mathrm{E}+03$ \\
\hline & Chumbo(Pb++, $\mathrm{Pb} 4+)$ & g & $5,87 E+01$ & $0,00 E+00$ & $0,00 E+00$ & $0,00 E+00$ & $0,00 E+00$ & $5,87 E+01$ \\
\hline & Manganês (Mn II, Mn IV, Mn VII) & g & $4,01 E+02$ & $0,00 E+00$ & $0,00 E+00$ & $0,00 E+00$ & $0,00 E+00$ & $4,01 E+02$ \\
\hline & Molibdênio (Mo II, Mo III, Mo IV, Mo V, Mo VI) & g & $1,47 E+02$ & $0,00 E+00$ & $0,00 E+00$ & $0,00 E+00$ & $0,00 E+00$ & $1,47 E+02$ \\
\hline & Níquel $(\mathrm{Ni++}, \mathrm{Ni3+})$ & g & $5,48 E+02$ & $0,00 E+00$ & $0,00 E+00$ & $0,00 E+00$ & $0,00 E+00$ & $5,48 E+02$ \\
\hline & Nitrato (NO3-) & g & $1,95 E+05$ & $0,00 \mathrm{E}+00$ & $0,00 E+00$ & $0,00 E+00$ & $0,00 E+00$ & $1,95 E+05$ \\
\hline & Compostos Nitrogenados (como N) & g & $1,43 E+04$ & $0,00 E+00$ & $0,00 E+00$ & $0,00 E+00$ & $0,00 E+00$ & $1,43 E+04$ \\
\hline & Compostos Fosforados (como P) & g & $2,35 E+02$ & $0,00 E+00$ & $0,00 E+00$ & $0,00 E+00$ & $0,00 E+00$ & $2,35 E+02$ \\
\hline & Dióxido de Silício (SiO2) & g & $2,22 E+04$ & $0,00 E+00$ & $0,00 E+00$ & $0,00 E+00$ & $0,00 E+00$ & $2,22 E+04$ \\
\hline & Compostos Sulfurados (como S) & g & $9,44 E+04$ & $0,00 E+00$ & $0,00 E+00$ & $0,00 E+00$ & $0,00 \mathrm{E}+00$ & $9,44 \mathrm{E}+04$ \\
\hline & Estanho $(\mathrm{Sn}++, \mathrm{Sn} 4+)$ & g & $1,47 E+01$ & $0,00 E+00$ & $0,00 E+00$ & $0,00 E+00$ & $0,00 E+00$ & $1,47 E+01$ \\
\hline & Zinco $(Z n++)$ & g & $2,01 E+02$ & $0,00 E+00$ & $0,00 E+00$ & $0,00 E+00$ & $0,00 E+00$ & $2,01 E+02$ \\
\hline & Materiais Suspensos & g & $6,61 E+03$ & $0,00 \mathrm{E}+00$ & $0,00 E+00$ & $0,00 E+00$ & $0,00 E+00$ & $0,00 E+00$ \\
\hline \multicolumn{9}{|c|}{ Resíduos Sólidos } \\
\hline & Resíduo (total) & $\mathrm{kg}$ & $6,83 E+04$ & $0,00 E+00$ & $0,00 E+00$ & $0,00 E+00$ & $0,00 E+00$ & $6,83 E+04$ \\
\hline & Resíduo proveniente da produção de aço (total) & $\mathrm{kg}$ & $7,43 E+03$ & $0,00 E+00$ & $0,00 E+00$ & $0,00 E+00$ & $0,00 E+00$ & $7,43 E+03$ \\
\hline \multirow[t]{7}{*}{ Indicadores } & Indicadores de Energia & & & & & & & \\
\hline & Energia de "estoque" & MJ & $1,44 E+05$ & $0,00 E+00$ & $0,00 E+00$ & $0,00 E+00$ & $0,00 E+00$ & $1,44 \mathrm{E}+05$ \\
\hline & Energia de combustível & MJ & $2,23 E+06$ & $6,36 \mathrm{E}+04$ & $0,00 E+00$ & $0,00 E+00$ & $5,07 E+04$ & $2,34 E+06$ \\
\hline & Energia Renovável & MJ & $1,02 E+05$ & $0,00 \mathrm{E}+00$ & $0,00 E+00$ & $1,51 E+05$ & $0,00 E+00$ & $2,53 E+05$ \\
\hline & Energia não Renovável & MJ & $2,13 E+06$ & $6,36 \mathrm{E}+04$ & $0,00 E+00$ & $0,00 E+00$ & $5,07 E+04$ & $2,24 E+06$ \\
\hline & Energia Elétrica & MJ & $4,58 \mathrm{E}+05$ & $1,51 E+04$ & $8,22 E+04$ & $1,51 E+05$ & $0,00 E+00$ & $7,06 \mathrm{E}+05$ \\
\hline & Energia Primária Total & $\mathrm{MJ}$ & $2,23 E+06$ & $7,87 E+04$ & $8,22 E+04$ & $1,51 \mathrm{E}+05$ & $5,07 \mathrm{E}+04$ & $2,59 \mathrm{E}+06$ \\
\hline
\end{tabular}


Apêndice G - Inventário do Ciclo de Vida do Sistema de Produto de Tubos em Aço Inoxidável 444, com 1,50 mm de espessura

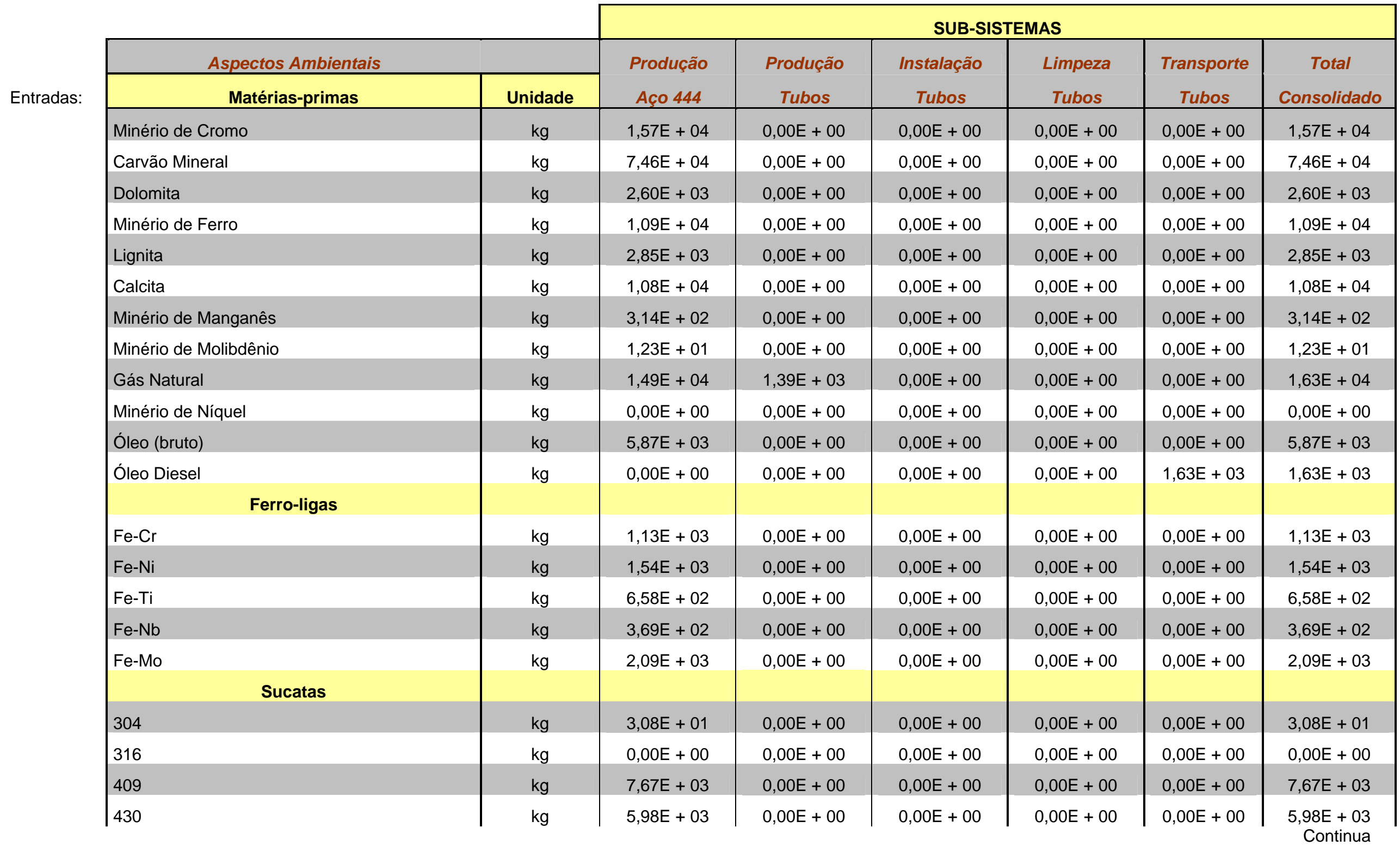




\begin{tabular}{|c|c|c|c|c|c|c|c|}
\hline Matérias-primas & Unidade & $\begin{array}{c}\text { Produção Aço } \\
444 \\
\end{array}$ & $\begin{array}{c}\text { Produção } \\
\text { Tubos }\end{array}$ & $\begin{array}{c}\text { Instalação } \\
\text { Tubos }\end{array}$ & $\begin{array}{c}\text { Limpeza } \\
\text { Tubos } \\
\end{array}$ & $\begin{array}{c}\text { Transporte } \\
\text { Tubos }\end{array}$ & $\begin{array}{c}\text { Total } \\
\text { Consolidado } \\
\end{array}$ \\
\hline \multicolumn{8}{|l|}{ Sucatas } \\
\hline Outros Aços & $\mathrm{kg}$ & $1,80 E+03$ & $0,00 E+00$ & $0,00 E+00$ & $0,00 E+00$ & $0,00 E+00$ & $1,80 E+03$ \\
\hline Aço Carbono & $\mathrm{kg}$ & $4,62 E+04$ & $0,00 E+00$ & $0,00 E+00$ & $0,00 E+00$ & $0,00 E+00$ & $4,62 E+04$ \\
\hline \multicolumn{8}{|l|}{ Água de alimentação (Volume) } \\
\hline Água ou Processo (resfriamento, total) & litros & $1,32 E+06$ & $0,00 E+00$ & $0,00 E+00$ & $0,00 E+00$ & $0,00 E+00$ & $1,32 E+06$ \\
\hline Água Usada (total) & litros & $1,26 \mathrm{E}+06$ & $0,00 E+00$ & $0,00 E+00$ & $3,29 E+07$ & $0,00 E+00$ & $3,42 \mathrm{E}+07$ \\
\hline \multicolumn{8}{|l|}{ Emissões Aéreas } \\
\hline Dióxido de Carbono (CO2) & $g$ & $3,29 \mathrm{E}+08$ & $3,74 \mathrm{E}+06$ & $0,00 E+00$ & $0,00 E+00$ & $4,43 E+06$ & $3,37 E+08$ \\
\hline Monóxido de Carbono (CO) & g & $4,97 E+05$ & $0,00 E+00$ & $0,00 E+00$ & $0,00 E+00$ & $0,00 E+00$ & $4,97 E+05$ \\
\hline Cromo (Cr III, Cr VI) & $g$ & $7,98 \mathrm{E}+03$ & $0,00 E+00$ & $0,00 E+00$ & $0,00 E+00$ & $0,00 E+00$ & $7,98 \mathrm{E}+03$ \\
\hline Cromo (Cr. VI) & $g$ & $1,29 E+01$ & $0,00 E+00$ & $0,00 E+00$ & $0,00 E+00$ & $0,00 E+00$ & $1,29 E+01$ \\
\hline Dioxinas (inespecificada) & $g$ & $2,03 E-05$ & $0,00 E+00$ & $0,00 E+00$ & $0,00 E+00$ & $0,00 E+00$ & $2,03 E-05$ \\
\hline Molibdênio (Mo, minério) & $g$ & $3,81 E+02$ & $0,00 E+00$ & $0,00 E+00$ & $0,00 E+00$ & $0,00 E+00$ & $3,81 E+02$ \\
\hline Níquel & $g$ & $1,90 \mathrm{E}+03$ & $0,00 E+00$ & $0,00 E+00$ & $0,00 E+00$ & $0,00 E+00$ & $1,90 E+03$ \\
\hline Óxidos de Nitrogênio (NOx como NO2) & $g$ & $7,95 E+05$ & $9,10 \mathrm{E}+04$ & $0,00 E+00$ & $0,00 E+00$ & $2,74 \mathrm{E}+02$ & $8,86 \mathrm{E}+05$ \\
\hline Materiais Particulados (inespecificado) & $g$ & $3,51 E+05$ & $0,00 E+00$ & $0,00 E+00$ & $0,00 E+00$ & $0,00 E+00$ & $3,51 E+05$ \\
\hline Óxidos de Enxofre (SOx como SO2) & $g$ & $1,40 E+06$ & $1,28 E+02$ & $0,00 E+00$ & $0,00 E+00$ & $6,11 E+03$ & $1,40 E+06$ \\
\hline \multicolumn{8}{|l|}{ Emissões Aquosas } \\
\hline Ácidos $(\mathrm{H}+)$ & $g$ & $5,25 E+03$ & $0,00 E+00$ & $0,00 E+00$ & $0,00 E+00$ & $0,00 E+00$ & $5,25 E+03$ \\
\hline Alumínio (Al3+) & $g$ & $1,57 E+03$ & $0,00 E+00$ & $0,00 E+00$ & $0,00 E+00$ & $0,00 E+00$ & $1,57 E+03$ \\
\hline Amônia (NH4+, NH3, as N) & g & $6,38 E+03$ & $0,00 E+00$ & $0,00 E+00$ & $0,00 E+00$ & $0,00 E+00$ & $6,38 \mathrm{E}+03$ \\
\hline Cádmio $(\mathrm{Cd}++)$ & $g$ & $1,23 E+01$ & $0,00 E+00$ & $0,00 E+00$ & $0,00 E+00$ & $0,00 E+00$ & $1,23 E+01$ \\
\hline Cloretos (Cl-) & $g$ & $4,09 E+05$ & $0,00 E+00$ & $0,00 E+00$ & $0,00 E+00$ & $0,00 E+00$ & $4,09 E+05$ \\
\hline Cromo (Cr III, Cr VI) & $g$ & $7,63 E+02$ & $0,00 E+00$ & $0,00 E+00$ & $0,00 E+00$ & $0,00 E+00$ & $7,63 E+02$ \\
\hline Cromo (Cr VI) & $g$ & $5,23 E+02$ & $0,00 E+00$ & $0,00 E+00$ & $0,00 E+00$ & $0,00 E+00$ & $5,23 E+02$ \\
\hline DQO (Demanda Química Oxigênio) & $g$ & $1,09 E+05$ & $0,00 E+00$ & $0,00 E+00$ & $0,00 E+00$ & $0,00 E+00$ & $1,09 E+05$ \\
\hline Cobre $(\mathrm{Cu}+, \mathrm{Cu}++)$ & $g$ & $2,46 E+01$ & $0,00 E+00$ & $0,00 E+00$ & $0,00 E+00$ & $0,00 E+00$ & $2,46 \mathrm{E}+01$ \\
\hline
\end{tabular}




\begin{tabular}{|c|c|c|c|c|c|c|c|c|}
\hline & & Unidade & $\begin{array}{c}\text { Produção Aço } \\
444\end{array}$ & $\begin{array}{c}\text { Produção } \\
\text { Tubos } \\
\end{array}$ & $\begin{array}{l}\text { Instalação } \\
\text { Tubos }\end{array}$ & $\begin{array}{c}\text { Limpeza } \\
\text { Tubos } \\
\end{array}$ & $\begin{array}{c}\text { Transporte } \\
\text { Tubos } \\
\end{array}$ & $\begin{array}{c}\text { Total } \\
\text { Consolidado } \\
\end{array}$ \\
\hline & \multicolumn{8}{|l|}{ Emissões Aquosas } \\
\hline & Fluoretos (F-) & g & $9,72 E+03$ & $0,00 E+00$ & $0,00 E+00$ & $0,00 E+00$ & $0,00 E+00$ & $9,72 E+03$ \\
\hline & Hidrocarbonetos (inespecificados) & g & $5,20 \mathrm{E}+03$ & $0,00 \mathrm{E}+00$ & $0,00 \mathrm{E}+00$ & $0,00 E+00$ & $0,00 \mathrm{E}+00$ & $5,20 \mathrm{E}+03$ \\
\hline & Ferro $(\mathrm{Fe}++, \mathrm{Fe} 3+)$ & g & $8,00 E+03$ & $0,00 E+00$ & $0,00 \mathrm{E}+00$ & $0,00 E+00$ & $0,00 E+00$ & $8,00 E+03$ \\
\hline & Chumbo(Pb++, $\mathrm{Pb} 4+)$ & g & $7,38 \mathrm{E}+01$ & $0,00 E+00$ & $0,00 E+00$ & $0,00 E+00$ & $0,00 E+00$ & $7,38 E+01$ \\
\hline & Manganês (Mn II, Mn IV, Mn VII) & g & $5,04 \mathrm{E}+02$ & $0,00 \mathrm{E}+00$ & $0,00 E+00$ & $0,00 E+00$ & $0,00 E+00$ & $5,04 \mathrm{E}+02$ \\
\hline & Molibdênio (Mo II, Mo III, Mo IV, Mo V, Mo VI) & g & $1,85 E+02$ & $0,00 E+00$ & $0,00 E+00$ & $0,00 E+00$ & $0,00 E+00$ & $1,85 \mathrm{E}+02$ \\
\hline & Níquel (Ni++, $\mathrm{Ni3+}$ ) & g & $6,89 E+02$ & $0,00 E+00$ & $0,00 E+00$ & $0,00 E+00$ & $0,00 E+00$ & $6,89 E+02$ \\
\hline & Nitrato (NO3-) & g & $2,45 E+05$ & $0,00 E+00$ & $0,00 E+00$ & $0,00 E+00$ & $0,00 E+00$ & $2,45 E+05$ \\
\hline & Compostos Nitrogenados (como N) & g & $1,80 \mathrm{E}+04$ & $0,00 E+00$ & $0,00 E+00$ & $0,00 E+00$ & $0,00 \mathrm{E}+00$ & $1,80 E+04$ \\
\hline & Compostos Fosforados (como P) & g & $2,95 E+02$ & $0,00 E+00$ & $0,00 E+00$ & $0,00 E+00$ & $0,00 E+00$ & $2,95 E+02$ \\
\hline & Dióxido de Silício (SiO2) & g & $2,79 E+04$ & $0,00 E+00$ & $0,00 E+00$ & $0,00 E+00$ & $0,00 E+00$ & $2,79 E+04$ \\
\hline & Compostos Sulfurados (como S) & g & $1,19 E+05$ & $0,00 E+00$ & $0,00 E+00$ & $0,00 E+00$ & $0,00 E+00$ & $1,19 E+05$ \\
\hline & Estanho $(\mathrm{Sn}++, \mathrm{Sn} 4+)$ & g & $1,85 E+01$ & $0,00 E+00$ & $0,00 E+00$ & $0,00 E+00$ & $0,00 \mathrm{E}+00$ & $1,85 E+01$ \\
\hline & Zinco $(Z n++)$ & g & $2,52 E+02$ & $0,00 E+00$ & $0,00 E+00$ & $0,00 E+00$ & $0,00 \mathrm{E}+00$ & $2,52 E+02$ \\
\hline & Materiais Suspensos & g & $8,31 E+03$ & $0,00 E+00$ & $0,00 E+00$ & $0,00 E+00$ & $0,00 \mathrm{E}+00$ & $8,31 E+03$ \\
\hline & \multicolumn{8}{|l|}{ Resíduos Sólidos } \\
\hline & Resíduo (total) & $\mathrm{kg}$ & $8,59 E+04$ & $0,00 E+00$ & $0,00 E+00$ & $0,00 E+00$ & $0,00 E+00$ & $8,59 E+04$ \\
\hline & $\begin{array}{l}\text { Resíduo proveniente da produção de aço } \\
\text { (total) }\end{array}$ & $\mathrm{Kg}$ & $9,34 E+03$ & $0,00 E+00$ & $0,00 E+00$ & $0,00 E+00$ & $0,00 E+00$ & $9,34 E+03$ \\
\hline \multirow[t]{7}{*}{ Indicadores } & \multicolumn{8}{|l|}{ Indicadores de Energia } \\
\hline & Energia de "estoque" & MJ & $1,81 E+05$ & $0,00 E+00$ & $0,00 E+00$ & $0,00 E+00$ & $0,00 \mathrm{E}+00$ & $1,81 E+05$ \\
\hline & Energia de combustível & MJ & $2,81 E+06$ & $8,00 E+04$ & $0,00 E+00$ & $0,00 E+00$ & $6,38 E+04$ & $2,87 E+06$ \\
\hline & Energia Renovável & MJ & $1,28 E+05$ & $0,00 E+00$ & $0,00 E+00$ & $1,53 E+05$ & $0,00 E+00$ & $2,81 E+06$ \\
\hline & Energia não Renovável & MJ & $2,80 E+06$ & $8,00 E+04$ & $0,00 E+00$ & $0,00 E+00$ & $6,38 E+04$ & $2,94 E+06$ \\
\hline & Energia Elétrica & MJ & $5,76 \mathrm{E}+05$ & $1,90 E+04$ & $8,36 \mathrm{E}+04$ & $1,53 E+05$ & $0,00 E+00$ & $8,32 E+05$ \\
\hline & Energia Primária Total & $\mathrm{MJ}$ & $2,80 E+06$ & $9,90 \mathrm{E}+04$ & $8,36 \mathrm{E}+04$ & $1,53 \mathrm{E}+05$ & $6,38 \mathrm{E}+04$ & $3,20 \mathrm{E}+06$ \\
\hline
\end{tabular}


Apêndice H - Inventário do Ciclo de Vida do Sistema de Produto de Tubos em Aço Inoxidável 439, com 1,50 mm de espessura

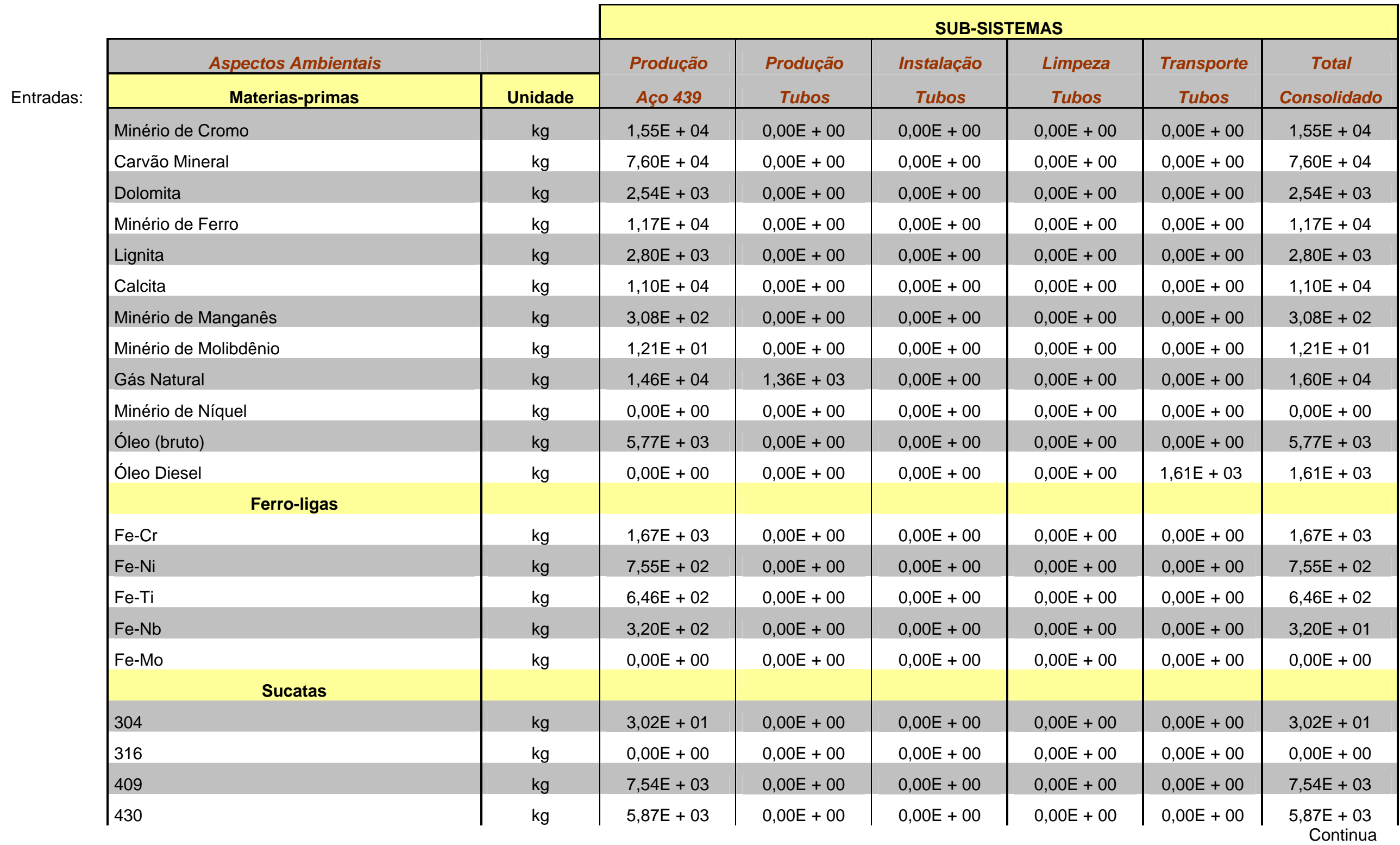




\begin{tabular}{|c|c|c|c|c|c|c|c|}
\hline Matérias-primas & Unidade & \begin{tabular}{|c} 
Produção Aço \\
439 \\
\end{tabular} & $\begin{array}{c}\text { Produção } \\
\text { Tubos }\end{array}$ & $\begin{array}{c}\text { Instalação } \\
\text { Tubos }\end{array}$ & $\begin{array}{c}\text { Limpeza } \\
\text { Tubos }\end{array}$ & $\begin{array}{c}\text { Transporte } \\
\text { Tubos }\end{array}$ & $\begin{array}{c}\text { Total } \\
\text { Consolidado } \\
\end{array}$ \\
\hline \multicolumn{8}{|l|}{ Sucatas } \\
\hline Outros Aços & $\mathrm{kg}$ & $1,77 E+03$ & $0,00 E+00$ & $0,00 E+00$ & $0,00 E+00$ & $0,00 E+00$ & $1,77 E+03$ \\
\hline Aço Carbono & $\mathrm{kg}$ & $4,54 \mathrm{E}+04$ & $0,00 \mathrm{E}+00$ & $0,00 \mathrm{E}+00$ & $0,00 E+00$ & $0,00 E+00$ & $4,54 \mathrm{E}+04$ \\
\hline \multicolumn{8}{|l|}{ Água de alimentação (Volume) } \\
\hline Água ou Processo (resfriamento, total) & litros & $1,30 E+06$ & $0,00 E+00$ & $0,00 E+00$ & $0,00 E+00$ & $0,00 E+00$ & $1,30 E+06$ \\
\hline Água Usada (total) & litros & $1,22 E+06$ & $0,00 E+00$ & $0,00 E+00$ & $3,29 E+07$ & $0,00 \mathrm{E}+00$ & $3,41 E+07$ \\
\hline \multicolumn{8}{|l|}{ Emissões Aéreas } \\
\hline Dióxido de Carbono (CO2) & g & $3,30 E+08$ & $3,67 E+06$ & $0,00 E+00$ & $0,00 E+00$ & $4,35 E+06$ & $3,38 \mathrm{E}+08$ \\
\hline Monóxido de Carbono (CO) & $g$ & $4,88 E+05$ & $0,00 E+00$ & $0,00 E+00$ & $0,00 \mathrm{E}+00$ & $0,00 \mathrm{E}+00$ & $4,88 \mathrm{E}+05$ \\
\hline Cromo (Cr III, Cr VI) & $g$ & $8,05 E+03$ & $0,00 E+00$ & $0,00 E+00$ & $0,00 E+00$ & $0,00 E+00$ & $8,05 E+03$ \\
\hline Cromo (Cr. VI) & g & $1,33 E+01$ & $0,00 E+00$ & $0,00 E+00$ & $0,00 E+00$ & $0,00 E+00$ & $1,33 E+01$ \\
\hline Dioxinas (inespecificada) & $g$ & $1,99 \mathrm{E}-05$ & $0,00 E+00$ & $0,00 E+00$ & $0,00 E+00$ & $0,00 E+00$ & $1,99 \mathrm{E}-05$ \\
\hline Molibdênio (Mo, minério) & $g$ & $3,75 E+02$ & $0,00 E+00$ & $0,00 E+00$ & $0,00 E+00$ & $0,00 E+00$ & $3,75 E+02$ \\
\hline Níquel & g & $1,87 \mathrm{E}+03$ & $0,00 E+00$ & $0,00 E+00$ & $0,00 E+00$ & $0,00 E+00$ & $1,87 E+03$ \\
\hline Óxidos de Nitrogênio (NOx como NO2) & g & $7,82 \mathrm{E}+05$ & $8,97 E+04$ & $0,00 E+00$ & $0,00 \mathrm{E}+00$ & $2,69 \mathrm{E}+02$ & $8,72 \mathrm{E}+05$ \\
\hline Materiais Particulados (inespecificado) & $g$ & $3,45 E+05$ & $0,00 E+00$ & $0,00 E+00$ & $0,00 E+00$ & $0,00 \mathrm{E}+00$ & $3,45 E+05$ \\
\hline Óxidos de Enxofre (SOx como SO2) & g & $1,40 E+06$ & $1,26 \mathrm{E}+02$ & $0,00 E+00$ & $0,00 E+00$ & $6,00 E+03$ & $1,40 E+06$ \\
\hline \multicolumn{8}{|l|}{ Emissões Aquosas } \\
\hline Ácidos $(\mathrm{H}+)$ & g & $5,16 E+03$ & $0,00 E+00$ & $0,00 \mathrm{E}+00$ & $0,00 \mathrm{E}+00$ & $0,00 E+00$ & $5,16 \mathrm{E}+03$ \\
\hline Alumínio (Al3+) & $g$ & $1,54 \mathrm{E}+03$ & $0,00 E+00$ & $0,00 E+00$ & $0,00 E+00$ & $0,00 E+00$ & $1,54 \mathrm{E}+03$ \\
\hline Amônia (NH4+, NH3, as N) & $g$ & $6,27 E+03$ & $0,00 E+00$ & $0,00 E+00$ & $0,00 E+00$ & $0,00 E+00$ & $6,27 E+03$ \\
\hline Cádmio $(\mathrm{Cd}++)$ & $g$ & $1,21 E+01$ & $0,00 E+00$ & $0,00 E+00$ & $0,00 E+00$ & $0,00 E+00$ & $1,21 E+01$ \\
\hline Cloretos (Cl-) & $g$ & $4,02 E+05$ & $0,00 E+00$ & $0,00 E+00$ & $0,00 E+00$ & $0,00 E+00$ & $4,02 E+05$ \\
\hline Cromo (Cr III, Cr VI) & $g$ & $7,67 E+02$ & $0,00 E+00$ & $0,00 E+00$ & $0,00 \mathrm{E}+00$ & $0,00 E+00$ & $7,67 E+02$ \\
\hline Cromo (Cr VI) & $g$ & $5,26 E+02$ & $0,00 E+00$ & $0,00 E+00$ & $0,00 E+00$ & $0,00 E+00$ & $5,26 \mathrm{E}+02$ \\
\hline DQO (Demanda Química Oxigenio) & $g$ & $1,07 E+05$ & $0,00 E+00$ & $0,00 E+00$ & $0,00 E+00$ & $0,00 E+00$ & $1,07 \mathrm{E}+05$ \\
\hline Cobre $(\mathrm{Cu}+, \mathrm{Cu}++)$ & $g$ & $2,42 \mathrm{E}+01$ & $0,00 \mathrm{E}+00$ & $0,00 E+00$ & $0,00 \mathrm{E}+00$ & $0,00 \mathrm{E}+00$ & 2,42 \\
\hline
\end{tabular}




\begin{tabular}{|c|c|c|c|c|c|c|c|c|}
\hline & & Unidade & $\begin{array}{c}\text { Produção Aço } \\
439\end{array}$ & $\begin{array}{c}\text { Produção } \\
\text { Tubos } \\
\end{array}$ & $\begin{array}{c}\text { Instalação } \\
\text { Tubos } \\
\end{array}$ & $\begin{array}{c}\text { Limpeza } \\
\text { Tubos } \\
\end{array}$ & $\begin{array}{c}\text { Transporte } \\
\text { Tubos } \\
\end{array}$ & $\begin{array}{c}\text { Total } \\
\text { Consolidado } \\
\end{array}$ \\
\hline & \multicolumn{8}{|l|}{ Emissões Aquosas } \\
\hline & Fluoretos (F-) & g & $9,53 E+03$ & $0,00 E+00$ & $0,00 E+00$ & $0,00 E+00$ & $0,00 E+00$ & $9,53 E+03$ \\
\hline & Hidrocarbonetos (inespecificados) & g & $5,11 E+03$ & $0,00 \mathrm{E}+00$ & $0,00 E+00$ & $0,00 E+00$ & $0,00 E+00$ & $5,11 E+03$ \\
\hline & Ferro $(\mathrm{Fe}++, \mathrm{Fe} 3+)$ & g & $8,02 E+03$ & $0,00 E+00$ & $0,00 E+00$ & $0,00 E+00$ & $0,00 \mathrm{E}+00$ & $8,02 E+03$ \\
\hline & Chumbo $(\mathrm{Pb}++, \mathrm{Pb} 4+)$ & g & $7,25 E+01$ & $0,00 E+00$ & $0,00 E+00$ & $0,00 E+00$ & $0,00 E+00$ & $7,25 E+01$ \\
\hline & Manganês (Mn II, Mn IV, Mn VII) & g & $4,96 \mathrm{E}+02$ & $0,00 E+00$ & $0,00 E+00$ & $0,00 E+00$ & $0,00 E+00$ & $4,96 \mathrm{E}+02$ \\
\hline & Molibdênio (Mo II, Mo III, Mo IV, Mo V, Mo VI) & g & $1,81 E+02$ & $0,00 E+00$ & $0,00 E+00$ & $0,00 E+00$ & $0,00 E+00$ & $1,81 E+02$ \\
\hline & Níquel (Ni++, $\mathrm{Ni3+}$ ) & g & $6,77 E+02$ & $0,00 E+00$ & $0,00 E+00$ & $0,00 E+00$ & $0,00 \mathrm{E}+00$ & $6,77 E+02$ \\
\hline & Nitrato (NO3-) & g & $2,41 E+05$ & $0,00 E+00$ & $0,00 E+00$ & $0,00 E+00$ & $0,00 E+00$ & $2,41 E+05$ \\
\hline & Compostos Nitrogenados (como N) & g & $1,77 E+04$ & $0,00 E+00$ & $0,00 E+00$ & $0,00 E+00$ & $0,00 E+00$ & $1,77 E+04$ \\
\hline & Compostos Fosforados (como P) & g & $2,90 E+02$ & $0,00 E+00$ & $0,00 E+00$ & $0,00 E+00$ & $0,00 E+00$ & $2,90 \mathrm{E}+02$ \\
\hline & Dióxido de Silício (SiO2) & g & $2,74 \mathrm{E}+04$ & $0,00 E+00$ & $0,00 E+00$ & $0,00 E+00$ & $0,00 \mathrm{E}+00$ & $2,74 \mathrm{E}+04$ \\
\hline & Compostos Sulfurados (como S) & g & $1,17 \mathrm{E}+05$ & $0,00 E+00$ & $0,00 E+00$ & $0,00 E+00$ & $0,00 E+00$ & $1,17 E+05$ \\
\hline & Estanho $(\mathrm{Sn}++, \mathrm{Sn} 4+)$ & g & $1,81 E+01$ & $0,00 E+00$ & $0,00 E+00$ & $0,00 E+00$ & $0,00 \mathrm{E}+00$ & $1,81 E+01$ \\
\hline & Zinco $(Z n++)$ & g & $2,48 \mathrm{E}+02$ & $0,00 E+00$ & $0,00 E+00$ & $0,00 E+00$ & $0,00 E+00$ & $2,48 \mathrm{E}+02$ \\
\hline & Materiais Suspensos & g & $8,16 E+03$ & $0,00 E+00$ & $0,00 E+00$ & $0,00 E+00$ & $0,00 E+00$ & $8,16 \mathrm{E}+03$ \\
\hline \multicolumn{9}{|c|}{ Resíduos Sólidos } \\
\hline & Resíduo (total) & $\mathrm{kg}$ & $8,44 \mathrm{E}+04$ & $0,00 E+00$ & $0,00 E+00$ & $0,00 E+00$ & $0,00 E+00$ & $8,44 \mathrm{E}+04$ \\
\hline & Resíduo proveniente da produção de aço (total) & $\mathrm{Kg}$ & $9,17 E+03$ & $0,00 E+00$ & $0,00 E+00$ & $0,00 E+00$ & $0,00 \mathrm{E}+00$ & $9,17 E+03$ \\
\hline \multirow[t]{7}{*}{ Indicadores } & Indicadores de Energia & & & & & & & \\
\hline & Energia de "estoque" & MJ & $1,78 \mathrm{E}+05$ & $0,00 E+00$ & $0,00 E+00$ & $0,00 E+00$ & $0,00 E+00$ & $1,78 \mathrm{E}+05$ \\
\hline & Energia de combustível & MJ & $2,81 E+06$ & $7,85 E+04$ & $0,00 E+00$ & $0,00 E+00$ & $6,26 \mathrm{E}+04$ & $2,95 E+06$ \\
\hline & Energia Renovável & MJ & $1,26 \mathrm{E}+05$ & $0,00 E+00$ & $0,00 E+00$ & $1,53 E+05$ & $0,00 E+00$ & $2,79 E+05$ \\
\hline & Energia não Renovável & MJ & $2,79 E+06$ & $7,85 E+04$ & $0,00 E+00$ & $0,00 E+00$ & $6,26 \mathrm{E}+04$ & $2,93 E+06$ \\
\hline & Energia Elétrica & MJ & $5,66 \mathrm{E}+05$ & $1,87 E+04$ & $8,36 \mathrm{E}+04$ & $1,53 E+05$ & $0,00 E+00$ & $8,21 E+05$ \\
\hline & Energia Primária Total & $\mathrm{MJ}$ & $2,92 E+06$ & $9,72 \mathrm{E}+04$ & $8,36 \mathrm{E}+04$ & $1,53 \mathrm{E}+05$ & $6,26 \mathrm{E}+04$ & $3,32 \mathrm{E}+06$ \\
\hline
\end{tabular}




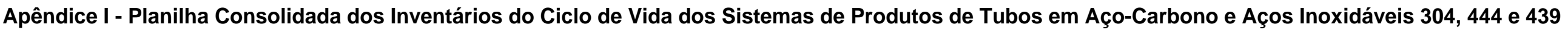

\begin{tabular}{|c|c|c|c|c|c|c|c|c|}
\hline \multirow[b]{3}{*}{ Entradas: } & \multicolumn{2}{|l|}{ Aspectos Ambientais } & \multicolumn{6}{|c|}{ SISTEMAS DE PRODUTOS } \\
\hline & \multirow{2}{*}{$\begin{array}{c}\text { Matérias-primas } \\
\text { Espessura de Parede } \mathrm{mm} \text { ) }\end{array}$} & \multirow[t]{2}{*}{ Unidade } & \multirow{2}{*}{$\frac{\text { Aço Carbono }}{2,65}$} & \multicolumn{2}{|c|}{ Aço 304} & \multicolumn{2}{|c|}{ Aço 444} & \multirow{2}{*}{ Aço 439} \\
\hline & & & & 1,20 & 1,50 & 1,20 & 1,50 & \\
\hline & Minério de Cromo & $\mathrm{kg}$ & $0,00 \mathrm{E}+00$ & $8,73 E+03$ & $1,10 \mathrm{E}+04$ & $1,25 E+04$ & $1,57 E+04$ & $1,55 E+04$ \\
\hline & Carvão Mineral & $\mathrm{kg}$ & $4,11 E+05$ & $5,63 E+04$ & $7,08 \mathrm{E}+04$ & $5,93 E+04$ & $7,46 E+04$ & $7,60 \mathrm{E}+04$ \\
\hline & Dolomita & $\mathrm{kg}$ & $1,62 E+04$ & $2,46 E+03$ & $3,10 E+03$ & $2,42 E+03$ & $2,60 \mathrm{E}+03$ & $2,54 \mathrm{E}+03$ \\
\hline & Minério de Ferro & $\mathrm{kg}$ & $1,06 \mathrm{E}+06$ & $1,38 \mathrm{E}+04$ & $1,74 \mathrm{E}+04$ & $8,65 E+03$ & $1,09 E+04$ & $1,17 E+04$ \\
\hline & Lignita & $\mathrm{kg}$ & $0,00 E+00$ & $2.92 E+03$ & $3,68 \mathrm{E}+03$ & $2,26 E+03$ & $2,85 E+03$ & $2,80 E+03$ \\
\hline & Calcita & $\mathrm{kg}$ & $1,39 E+04$ & $1,05 E+04$ & $1,32 E+04$ & $8,59 E+03$ & $1,08 \mathrm{E}+04$ & $1,10 E+04$ \\
\hline & Minério de Manganês & $\mathrm{kg}$ & $0,00 E+00$ & $9,51 E+02$ & $1,98 \mathrm{E}+03$ & $2.49 E+02$ & $3,14 \mathrm{E}+02$ & $3,08 E+02$ \\
\hline & Minério de Molibdênio & $\mathrm{kg}$ & $0,00 E+00$ & $5,48 E+01$ & $6,90 E+01$ & $9,78 E+00$ & $1,23 E+01$ & $1,21 E+01$ \\
\hline & Gás Natural & $\mathrm{kg}$ & $2,72 \mathrm{E}+04$ & $1,44 \mathrm{E}+04$ & $1,81 E+04$ & $1,30 E+04$ & $1,63 E+04$ & $1,60 \mathrm{E}+04$ \\
\hline & Minério de Níquel & $\mathrm{kg}$ & $0,00 E+00$ & $2,88 E+03$ & $3,63 E+03$ & $0,00 E+00$ & $0,00 E+00$ & $0,00 E+00$ \\
\hline & Óleo (bruto) & $\mathrm{kg}$ & $1,74 \mathrm{E}+04$ & $1,08 E+04$ & $1,36 \mathrm{E}+04$ & $4,67 E+03$ & $5,87 E+03$ & $5,77 E+03$ \\
\hline & Óleo Diesel & $\mathrm{kg}$ & $8,81 E+03$ & $1,32 E+03$ & $1,67 E+03$ & $1,30 E+03$ & $1,63 E+03$ & $1,61 E+03$ \\
\hline & Ferro-ligas & & & & & & & \\
\hline & $\mathrm{Fe}-\mathrm{Cr}$ & $\mathrm{kg}$ & $0,00 E+00$ & $0,00 E+00$ & $0,00 E+00$ & $9,00 E+02$ & $1,13 E+03$ & $1,67 E+03$ \\
\hline & $\mathrm{Fe}-\mathrm{Ni}$ & $\mathrm{kg}$ & $0,00 E+00$ & $0,00 E+00$ & $0,00 E+00$ & $1,22 E+03$ & $1,54 \mathrm{E}+03$ & $7,55 E+02$ \\
\hline & $\mathrm{Fe}-\mathrm{Ti}$ & $\mathrm{kg}$ & $0,00 E+00$ & $0,00 E+00$ & $0,00 E+00$ & $5,23 E+02$ & $6,58 \mathrm{E}+02$ & $6,46 \mathrm{E}+02$ \\
\hline & $\mathrm{Fe}-\mathrm{Nb}$ & $\mathrm{kg}$ & $0,00 E+00$ & $0,00 E+00$ & $0,00 E+00$ & $2,93 E+02$ & $3,69 E+02$ & $3,20 \mathrm{E}+01$ \\
\hline & Fe-Mo & $\mathrm{kg}$ & $0,00 E+00$ & $0,00 E+00$ & $0,00 E+00$ & $1,66 \mathrm{E}+03$ & $2,09 E+03$ & $0,00 E+00$ \\
\hline & Sucatas & & & & & & & \\
\hline & 304 & $\mathrm{~kg}$ & $0,00 E+00$ & $2,29 E+04$ & $2,88 E+04$ & $2,45 E+01$ & $3,08 E+01$ & $3,02 E+01$ \\
\hline & 316 & $\mathrm{~kg}$ & $0,00 E+00$ & $1,27 E+03$ & $1,59 E+03$ & $0,00 E+00$ & $0,00 E+00$ & $0,00 E+00$ \\
\hline & 409 & $\mathrm{~kg}$ & $0,00 E+00$ & $7,62 E+02$ & $9,59 E+02$ & $6,10 E+03$ & $7,67 E+03$ & $7,54 E+03$ \\
\hline & 430 & $\mathrm{~kg}$ & $0,00 E+00$ & $9,56 \mathrm{E}+02$ & $1,20 E+03$ & $4,75 E+03$ & $5,98 E+03$ & $5,87 E+03$ \\
\hline & Outros Aços & $\mathrm{kg}$ & $0,00 E+00$ & $1,87 E+03$ & $2,35 E+03$ & $1,43 E+03$ & $1,80 E+03$ & $1,77 E+03$ \\
\hline & Aço Carbono & $\mathrm{kg}$ & $7,45 E+04$ & $1,08 E+04$ & $1,37 E+04$ & $3,67 E+04$ & $4,62 E+04$ & $4,54 \mathrm{E}+04$ \\
\hline
\end{tabular}

Continua 


\begin{tabular}{|c|c|c|c|c|c|c|c|}
\hline $\begin{array}{c}\text { Matérias-primas } \\
\text { Espessura de Parede (mm) }\end{array}$ & Unidade & $\begin{array}{c}\text { Aço Carbono } \\
2,65 \\
\end{array}$ & $\begin{array}{l}304 \\
1,20 \\
\end{array}$ & $\begin{array}{l}304 \\
1,50 \\
\end{array}$ & $\begin{array}{l}444 \\
1,20 \\
\end{array}$ & $\begin{array}{l}444 \\
1,50 \\
\end{array}$ & $\begin{array}{l}439 \\
1,50 \\
\end{array}$ \\
\hline \multicolumn{8}{|l|}{ Água de alimentação (Volume) } \\
\hline Água de Processo (resfriamento, total) & litros & $0,00 E+00$ & $3,13 E+06$ & $3,94 \mathrm{E}+06$ & $1,05 E+06$ & $1,32 E+06$ & $1,30 \mathrm{E}+06$ \\
\hline Água Usada (total) & litros & $6,29 E+07$ & $3,33 E+07$ & $3,40 E+07$ & $3,34 \mathrm{E}+07$ & $3,42 E+07$ & $3,41 E+07$ \\
\hline \multicolumn{8}{|l|}{ Emissões Aéreas } \\
\hline Cádmio & g & $3,69 E+01$ & $0,00 E+00$ & $0,00 E+00$ & $0,00 E+00$ & $0,00 E+00$ & $0,00 E+00$ \\
\hline Dióxido de Carbono (CO2) & g & $1,37 \mathrm{E}+09$ & $3,11 E+08$ & $3,90 E+08$ & $2,65 E+08$ & $3,37 E+08$ & $3,38 \mathrm{E}+08$ \\
\hline Monóxido de Carbono (CO) & g & $1,73 E+07$ & $5,00 E+05$ & $6,30 E+05$ & $3,95 E+05$ & $4,97 \mathrm{E}+05$ & $4,88 \mathrm{E}+05$ \\
\hline Cromo (Cr III, Cr VI) & g & $2,34 \mathrm{E}+03$ & $4,58 \mathrm{E}+03$ & $5,76 \mathrm{E}+03$ & $6,34 \mathrm{E}+03$ & $7,98 \mathrm{E}+03$ & $8,05 E+03$ \\
\hline Cromo (Cr. VI) & g & $0,00 E+00$ & $4,98 \mathrm{E}+00$ & $6,27 E+00$ & $1,03 E+01$ & $1,29 E+01$ & $1,33 E+01$ \\
\hline Dioxinas (inespecificada) & g & $1,26 \mathrm{E}-02$ & $4,48 \mathrm{E}-04$ & $5,46 \mathrm{E}-04$ & $1,61 \mathrm{E}-05$ & 2,03E - 04 & 1,99E - 05 \\
\hline Molibdênio (Mo, minério) & g & $0,00 \mathrm{E}+00$ & $2,69 \mathrm{E}+02$ & $3,39 E+02$ & $3,03 E+02$ & $3,81 E+02$ & $3,75 E+02$ \\
\hline Níquel & g & $0,00 E+00$ & $3,88 \mathrm{E}+03$ & $4,88 \mathrm{E}+03$ & $1,51 E+03$ & $1,90 E+03$ & $1,87 E+03$ \\
\hline Óxidos de Nitrogênio (NOx como NO2) & g & $2,38 \mathrm{E}+06$ & $7,82 \mathrm{E}+05$ & $9,84 \mathrm{E}+05$ & $7,05 E+05$ & $8,86 \mathrm{E}+05$ & $8,72 \mathrm{E}+05$ \\
\hline Materiais Particulados (inespecificado) & g & $1,07 E+06$ & $3,45 E+05$ & $4,35 E+05$ & $2,79 E+05$ & $3,51 E+05$ & $3,45 \mathrm{E}+05$ \\
\hline Óxidos de Enxofre (SOx como SO2) & g & $1,45 E+06$ & $2,31 E+06$ & $2,93 E+06$ & $1,11 E+06$ & $1,40 E+06$ & $1,40 \mathrm{E}+06$ \\
\hline Ácido Clorídrico (HCl) & g & $3,00 E+04$ & $0,00 E+00$ & $0,00 \mathrm{E}+00$ & $0,00 E+00$ & $0,00 E+00$ & $0,00 E+00$ \\
\hline Sulfeto de Hidrogênio (H2S) & g & $4,34 \mathrm{E}+04$ & $0,00 E+00$ & $0,00 E+00$ & $0,00 E+00$ & $0,00 E+00$ & $0,00 E+00$ \\
\hline Chumbo $(\mathrm{Pb})$ & g & $2,10 E+03$ & $0,00 E+00$ & $0,00 E+00$ & $0,00 E+00$ & $0,00 E+00$ & $0,00 \mathrm{E}+00$ \\
\hline Mercúrio (Hg) & g & $3,97 E+01$ & $0,00 E+00$ & $0,00 E+00$ & $0,00 E+00$ & $0,00 E+00$ & $0,00 E+00$ \\
\hline Metano $(\mathrm{CH} 4)$ & g & $3,00 E+05$ & $0,00 E+00$ & $0,00 E+00$ & $0,00 E+00$ & $0,00 E+00$ & $0,00 E+00$ \\
\hline Óxido Nitroso (N2O) & g & $7,18 E+04$ & $0,00 E+00$ & $0,00 E+00$ & $0,00 E+00$ & $0,00 E+00$ & $0,00 E+00$ \\
\hline VOC (exceto metano) & g & $8,16 E+04$ & $0,00 E+00$ & $0,00 E+00$ & $0,00 E+00$ & $0,00 E+00$ & $0,00 E+00$ \\
\hline Zinco (Zn) & g & $2,10 E+03$ & $0,00 E+00$ & $0,00 E+00$ & $0,00 E+00$ & $0,00 E+00$ & $0,00 E+00$ \\
\hline \multicolumn{8}{|l|}{ Emissões Aquosas } \\
\hline Ácidos $(\mathrm{H}+)$ & g & $0,00 E+00$ & $4,16 E+03$ & $5,24 \mathrm{E}+03$ & $4,18 E+03$ & $5,25 E+03$ & $5,16 \mathrm{E}+03$ \\
\hline Alumínio (Al3+) & g & $0,00 E+00$ & $1,13 E+03$ & $1,42 E+03$ & $1,25 E+03$ & $1,57 E+03$ & $1,54 \mathrm{E}+03$ \\
\hline Amônia (NH4+, NH3, as N) & g & $6,15 E+04$ & $5,18 E+03$ & $6,52 E+00$ & $5,07 E+03$ & $6,38 E+03$ & $6,27 E+03$ \\
\hline Cádmio (Cd++) & g & $4,57 E+01$ & $9,96 \mathrm{E}+00$ & $1,25 E+01$ & $9,76 \mathrm{E}+00$ & $1,23 E+01$ & $1,21 E+01$ \\
\hline Cloretos (Cl-) & g & $0,00 E+00$ & $3,43 E+03$ & $4,31 E+05$ & $3,25 E+05$ & $4,09 E+05$ & $4,02 E+05$ \\
\hline
\end{tabular}




\begin{tabular}{|c|c|c|c|c|c|c|c|c|}
\hline & Espessura de Parede (mm) & Unidade & $\begin{array}{c}\text { Aço Carbono } \\
2,65\end{array}$ & $\begin{array}{l}304 \\
1,20 \\
\end{array}$ & $\begin{array}{l}304 \\
1,50 \\
\end{array}$ & $\begin{array}{l}444 \\
1,20 \\
\end{array}$ & $\begin{array}{l}444 \\
1,50 \\
\end{array}$ & $\begin{array}{l}439 \\
1,50 \\
\end{array}$ \\
\hline & \multicolumn{8}{|l|}{ Emissões Aquosas } \\
\hline & Cromo (Cr III, Cr VI) & g & $5,19 E+01$ & $5,58 \mathrm{E}+02$ & $7,02 E+02$ & $6,06 \mathrm{E}+02$ & $7,63 E+02$ & $7,67 \mathrm{E}+02$ \\
\hline & Cromo (Cr VI) & g & $0.00 E+00$ & $4,03 E+02$ & $5,08 E+02$ & $4,16 E+02$ & $5,23 E+02$ & $5,26 \mathrm{E}+02$ \\
\hline & DQO (Demanda Química Oxigênio) & g & $1,30 E+05$ & $8,75 E+04$ & $1,10 E+05$ & $8,65 E+04$ & $1,09 E+05$ & $1,07 \mathrm{E}+05$ \\
\hline & Fluoretos (F-) & g & $0,00 E+00$ & $6,26 \mathrm{E}+03$ & $7,88 \mathrm{E}+03$ & $7,72 E+03$ & $9,72 \mathrm{E}+03$ & $9,53 E+03$ \\
\hline & Hidrocarbonetos (inespecificados) & g & $0,00 \mathrm{E}+0$ & $3,26 E+03$ & $4,11 E+03$ & $4,14 \mathrm{E}+03$ & $5,20 E+03$ & $5,11 E+03$ \\
\hline & Ferro $(\mathrm{Fe}++, \mathrm{Fe} 3+)$ & $g$ & $1,09 E+04$ & $7,32 E+03$ & $9,21 E+03$ & $6,36 \mathrm{E}+03$ & $8,00 E+03$ & $8,02 E+03$ \\
\hline & Chumbo(Pb++, $\mathrm{Pb} 4+)$ & g & $-2,60 E+02$ & $9,46 \mathrm{E}+01$ & $9,21 E+03$ & $5,87 E+01$ & $7,38 \mathrm{E}+01$ & $7,25 E+01$ \\
\hline & Manganês (Mn II, Mn IV, Mn VII) & g & $0,00 E+00$ & $3,34 \mathrm{E}+02$ & $4,20 E+02$ & $4,01 E+02$ & $5,04 \mathrm{E}+02$ & $4,96 \mathrm{E}+02$ \\
\hline & Molibdênio (Mo II, III, IV, V, VI) & g & $0,00 E+00$ & $1,25 E+02$ & $1.57 \mathrm{E}+02$ & $1,47 E+02$ & $1,85 E+02$ & $1,81 E+02$ \\
\hline & Níquel (Ni++, $\mathrm{Ni3+})$ & g & $1,79 E+02$ & $4,23 E+02$ & $5,33 E+02$ & $5,48 \mathrm{E}+02$ & $6,89 E+02$ & $6,77 E+02$ \\
\hline & Nitrato (NO3-) & g & $0,00 E+00$ & $1,62 E+05$ & $2,05 E+05$ & $1,95 E+05$ & $2,45 E+05$ & $2,41 E+05$ \\
\hline & Compostos Nitrogenados (como N) & g & $1,43 E+04$ & $1,99 E+05$ & $2,50 E+05$ & $1,43 E+04$ & $1,80 \mathrm{E}+04$ & $1,77 \mathrm{E}+04$ \\
\hline & Compostos Fosforados (como P) & g & $1,20 \mathrm{E}+03$ & $2,34 \mathrm{E}+02$ & $2,95 E+02$ & $2,35 E+02$ & $2,95 E+02$ & $2,90 E+02$ \\
\hline & Dióxido de Silício (SiO2) & g & $0,00 E+00$ & $1,81 E+04$ & $2,28 E+04$ & $2,22 \mathrm{E}+04$ & $2,79 E+04$ & $2,74 \mathrm{E}+04$ \\
\hline & Compostos Sulfurados (como S) & g & $0,00 E+00$ & $7,46 \mathrm{E}+04$ & $9,39 E+04$ & $9,44 \mathrm{E}+04$ & $1,19 E+05$ & $1,17 \mathrm{E}+05$ \\
\hline & Zinco $(Z n++)$ & g & $1,08 E+03$ & $1,74 \mathrm{E}+02$ & $2,20 E+02$ & $2,01 E+02$ & $2,52 E+02$ & $2,48 E+02$ \\
\hline & Materiais Suspensos & g & $1,08 E+05$ & $1,95 E+03$ & $2,46 \mathrm{E}+03$ & $6,61 E+03$ & $8,31 E+03$ & $8,16 \mathrm{E}+03$ \\
\hline \multicolumn{9}{|c|}{ Resíduos Sólidos } \\
\hline & Resíduo (total) & $\mathrm{kg}$ & $9,56 \mathrm{E}+05$ & $1,67 E+05$ & $2,10 E+05$ & $6,83 E+04$ & $8,59 E+04$ & $8,44 \mathrm{E}+04$ \\
\hline & Resíduo proveniente da produção de aço & $\mathrm{kg}$ & $0,00 E+00$ & $8,42 E+03$ & $1,06 \mathrm{E}+04$ & $7,43 E+03$ & $9,34 \mathrm{E}+03$ & $9,17 E+03$ \\
\hline & Sub-produtos não Alocados & $\mathrm{kg}$ & $4,10 E+04$ & $0,00 E+00$ & $0,00 E+00$ & $0,00 E+00$ & $0,00 E+00$ & $0,00 E+00$ \\
\hline \multirow[t]{7}{*}{ Indicadores } & \multicolumn{8}{|l|}{ Indicadores de Energia } \\
\hline & Energia de "estoque" & $\mathrm{MJ}$ & $-2,65 E+05$ & $2,03 E+05$ & $2,56 E+05$ & $1,44 \mathrm{E}+05$ & $1,81 E+05$ & $1,78 \mathrm{E}+05$ \\
\hline & Energia de combustível & $\mathrm{MJ}$ & $1,62 E+07$ & $2,60 E+06$ & $3,28 \mathrm{E}+06$ & $2,34 E+06$ & $2,67 E+06$ & $2,95 E+06$ \\
\hline & Energia Renovável & $\mathrm{MJ}$ & $6,66 \mathrm{E}+05$ & $3,75 E+05$ & $3,11 E+05$ & $2,53 E+05$ & $2,81 E+06$ & $2,79 E+06$ \\
\hline & Energia não Renovável & MJ & $1,49 E+07$ & $2,68 \mathrm{E}+06$ & $3,38 E+06$ & $2,24 \mathrm{E}+06$ & $2,94 E+06$ & $2,93 E+06$ \\
\hline & Energia Elétrica & $\mathrm{MJ}$ & $5,16 E+05$ & $7,20 E+05$ & $8,49 E+05$ & $7,06 \mathrm{E}+05$ & $8,32 \mathrm{E}+05$ & $8,21 E+05$ \\
\hline & Energia Primária Total & $\mathrm{MJ}$ & $1,64 \mathrm{E}+07$ & $3,06 \mathrm{E}+06$ & $3,79 E+06$ & $2,59 \mathrm{E}+06$ & $3,20 E+06$ & $3,32 \mathrm{E}+06$ \\
\hline
\end{tabular}




\section{ANEXO A}

Este anexo apresenta os potenciais de alguns gases para as categorias de impactos mais utilizadas nos estudos de AICV.

Tabela 1 - Potencial de Aquecimento Global (PAG) dado em kgCO2-eq/kg-gas (Albritton et ali.,1996, apud Carvalho, C. E.)

\begin{tabular}{|c|c|c|c|}
\hline Substância & Fórmula & $\begin{array}{l}\text { PAG } \\
100\end{array}$ & $\begin{array}{c}\text { Tempo de Vida, } \\
\text { (anos) }\end{array}$ \\
\hline Carbon dioxide & $\mathrm{CO}_{2}$ & 1 & 150 \\
\hline Methane & $\mathrm{CH}_{4}$ & 25 & 10 \\
\hline Nitrogen dioxide & $\mathrm{NO}_{2}$ & 320 & 120 \\
\hline Tetrachloromethane & $\mathrm{CCl}_{4}$ & 1,400 & 42 \\
\hline Trichloromethane & $\mathrm{CHCl}_{3}$ & 5 & 0,55 \\
\hline Dichloromethane & $\mathrm{CH}_{2} \mathrm{Cl}_{2}$ & 9 & 0,41 \\
\hline Chloromethane & $\mathrm{CH}_{3} \mathrm{Cl}$ & 25 & 0,7 \\
\hline $1,1,1$ - trichloroethane & $\mathrm{CH}_{3} \mathrm{CCl}_{3}$ & 110 & 5,4 \\
\hline Tetrafluoromethane & $\mathrm{CF}_{4}$ & 6,300 & 50,000 \\
\hline Hexafluoroethane & $\mathrm{C}_{2} \mathrm{~F}_{6}$ & 12,500 & 10,000 \\
\hline CFC - 11 & $\mathrm{CFCl}_{3}$ & 4,000 & 50 \\
\hline CFC - 12 & $\mathrm{CF}_{2} \mathrm{Cl}_{2}$ & 8,500 & 102 \\
\hline CFC -13 & $\mathrm{CF}_{3} \mathrm{Cl}$ & 11,700 & 640 \\
\hline CFC - 113 & $\mathrm{CF}_{2} \mathrm{ClCFCl}_{2}$ & 5,000 & 85 \\
\hline CFC - 114 & $\mathrm{CF}_{2} \mathrm{ClCF}_{2} \mathrm{Cl}$ & 9,300 & 300 \\
\hline CFC - 115 & $\mathrm{CF}_{2} \mathrm{ClCF}_{3}$ & 9,300 & 1,700 \\
\hline HCFC - 22 & $\mathrm{CHF}_{2} \mathrm{Cl}$ & 1,700 & 13 \\
\hline HCFC - 123 & $\mathrm{CF}_{3} \mathrm{CHCl}_{2}$ & 93 & 1,4 \\
\hline HCFC - 124 & $\mathrm{CF}_{3} \mathrm{CHFCl}$ & 480 & 5,9 \\
\hline HCFC - 141b & $\mathrm{CFCl}_{2} \mathrm{CH}_{3}$ & 630 & 9,4 \\
\hline HCFC - 142b & $\mathrm{CF}_{2} \mathrm{ClCH}_{3}$ & 2,000 & 19,5 \\
\hline HCFC $-225 \mathrm{ca}$ & $\mathrm{C}_{3} \mathrm{~F}_{5} \mathrm{HCl}_{2}$ & 170 & 2,5 \\
\hline HCFC $-225 c b$ & $\mathrm{C}_{3} \mathrm{~F}_{5} \mathrm{HCl}_{2}$ & 530 & 6,6 \\
\hline $\mathrm{HFC}-23$ & $\mathrm{CHF}_{3}$ & 12,100 & 250 \\
\hline $\mathrm{HFC}-32$ & $\mathrm{CH}_{2} \mathrm{~F}_{2}$ & 580 & 6 \\
\hline $\mathrm{HFC}-43-10 \mathrm{me}$ & $\mathrm{C}_{5} \mathrm{H}_{2} \mathrm{~F}_{10}$ & 1,600 & 21 \\
\hline HFC - 125 & $\mathrm{CF}_{3} \mathrm{CHF}_{2}$ & 3,200 & 36 \\
\hline $\mathrm{HFC}-134$ & $\mathrm{CHF}_{2} \mathrm{CHF}_{2}$ & 1,200 & 12 \\
\hline$H F C-134 a$ & $\mathrm{CH}_{2} \mathrm{FCF}_{3}$ & 1,300 & 14 \\
\hline HFC - 143 & $\mathrm{CHF}_{2} \mathrm{CH}_{2} \mathrm{~F}$ & 290 & 3,5 \\
\hline HFC - 143 & $\mathrm{CF}_{3} \mathrm{CH}_{3}$ & 4,400 & 55 \\
\hline
\end{tabular}




\begin{tabular}{lccc}
\multicolumn{1}{r}{ Substância } & Fórmula & $\begin{array}{c}\text { PAG } \\
\mathbf{1 0 0}\end{array}$ & $\begin{array}{c}\text { Tempo de Vida, } \\
\text { (anos) }\end{array}$ \\
\hline $\mathrm{HFC}-152 \mathrm{a}$ & & 140 & 1,5 \\
$\mathrm{HFC}-227 \mathrm{ea}$ & $\mathrm{CHF}_{2} \mathrm{CH}_{3}$ & 3,300 & 41 \\
$\mathrm{HFC}-236 \mathrm{fa}$ & $\mathrm{C}_{3} \mathrm{HF}_{7}$ & 8,000 & 250 \\
$\mathrm{HFC}-245 \mathrm{ca}$ & $\mathrm{C}_{3} \mathrm{H}_{2} \mathrm{~F}_{6}$ & 610 & 7 \\
& $\mathrm{C}_{3} \mathrm{H}_{3} \mathrm{~F}_{5}$ & & \\
Halon 1301 & & 5,600 & 65 \\
Súlfur hexafluoride & $\mathrm{CF}_{3} \mathrm{Br}$ & 24,900 & 3,200 \\
Carbon monoxide & $\mathrm{SF}_{6}$ & - & Months \\
Non-Methane VOC & $\mathrm{CO}$ & - & Days-Months \\
Nitrogen oxides & - & - & Days \\
\hline & $\mathrm{NO}_{\mathbf{x}}$ & & Conclusão
\end{tabular}

Tabela 2 - Potencial de Depleção da Camada de Ozônio (PDCO) dado em kgCFC11-eq/kg-gas (Solomon \& Wuebbles, 1995, apud Carvalho, C. E.)

\begin{tabular}{|c|c|c|c|}
\hline Substância & Fórmula & $\begin{array}{c}\text { PDCO } \\
100 \text { anos }\end{array}$ & $\begin{array}{c}\text { Tempo de Vida, } \\
\text { (anos) }\end{array}$ \\
\hline CFC - 11 & $\mathrm{CFCl}_{3}$ & 1.00 & $50+/-5$ \\
\hline CFC - 12 & $\mathrm{CF}_{2} \mathrm{Cl}_{2}$ & - & 102 \\
\hline CFC - 113 & $\mathrm{CF}_{2} \mathrm{ClCFCl}_{2}$ & 0.78 & 85 \\
\hline CFC - 114 & $\mathrm{CF}_{2} \mathrm{ClCF}_{2} \mathrm{Cl}$ & - & 300 \\
\hline CFC - 115 & $\mathrm{CF}_{2} \mathrm{ClCF}_{3}$ & - & 1.700 \\
\hline Tetrachloromethane & $\mathrm{CCl}_{4}$ & 1.14 & 42 \\
\hline HCFC - 22 & $\mathrm{CHF}_{2} \mathrm{Cl}$ & 0.07 & 13.3 \\
\hline HCFC - 123 & $\mathrm{CF}_{3} \mathrm{CHCl}_{2}$ & 0.03 & 1.4 \\
\hline HCFC - 124 & $\mathrm{CF}_{3} \mathrm{CHFCl}$ & 0.03 & 5.9 \\
\hline HCFC - 141b & $\mathrm{CFCl}_{2} \mathrm{CH}_{3}$ & 0.13 & 9.4 \\
\hline HCFC - 142b & $\mathrm{CF}_{2} \mathrm{ClCH}_{3}$ & 0.08 & 19.5 \\
\hline HCFC $-225 \mathrm{ca}$ & $\mathrm{C}_{3} \mathrm{~F}_{5} \mathrm{HCl}_{2}$ & 0.03 & 2.5 \\
\hline HCFC $-225 c b$ & $\mathrm{C}_{3} \mathrm{~F}_{5} \mathrm{HCl}_{2}$ & 0.04 & 6.6 \\
\hline 1,1,1 - trichlorethan & $\mathrm{CH}_{3} \mathrm{CCl}_{3}$ & 0.15 & $5.4+/-0.4$ \\
\hline Halon1301 & $\mathrm{CF}_{3} \mathrm{Br}$ & 11.5 & 65 \\
\hline Halon 1211 & $\mathrm{CF}_{2} \mathrm{ClBr}$ & 4.9 & 20 \\
\hline Halon 1202 & $\mathrm{CF}_{2} \mathrm{Br}_{2}$ & 7.0 & - \\
\hline Halon 2402 & $\mathrm{CF}_{2} \mathrm{BrCF}_{2} \mathrm{Br}$ & - & 25 \\
\hline HBFC 1201 & $\mathrm{CF}_{2} \mathrm{HBr}$ & - & - \\
\hline HBFC 2401 & $\mathrm{CF}_{3} \mathrm{CHFBr}$ & - & - \\
\hline HBFC 2311 & $\mathrm{CF}_{3} \mathrm{CHClBr}$ & - & - \\
\hline Methylbromid & $\mathrm{CH}_{3} \mathrm{Br}$ & 0.69 & 1.3 \\
\hline
\end{tabular}


Tabela 3 - Potencial de Formação de Oxidantes Fotoquímicos (PFOF) dado em kgEteno-eq/kg-gas (Heijungs et ali., 1992, apud Carvalho, C. E.)

\begin{tabular}{|c|c|}
\hline Substância & $\begin{array}{c}\text { PFOF } \\
\text { (Média de } 3 \text { regiões da Europa) }\end{array}$ \\
\hline \multicolumn{2}{|l|}{ Alkanes } \\
\hline Methane & 0.007 \\
\hline Ethane & 0.082 \\
\hline Propane & 0.420 \\
\hline $\mathrm{N}$-Butane & 0.410 \\
\hline I-Butane & 0.315 \\
\hline $\mathrm{N}$ - Pentane & 0.408 \\
\hline I - Pentane & 0.296 \\
\hline $\mathrm{N}$ - Hexane & 0.421 \\
\hline 2 - Methylpentane & 0.524 \\
\hline 3-Methylpentane & 0.431 \\
\hline 2,2 - Dimethylbutane & 0.251 \\
\hline 2,3 - Dimethylbutane & 0.384 \\
\hline $\mathrm{N}$ - Heptane & 0.529 \\
\hline 2 - Methylhexane & 0.492 \\
\hline 3 - Methylhexane & 0.492 \\
\hline $\mathrm{N}$ - Octane & 0.493 \\
\hline 2 - Methylheptane & 0.469 \\
\hline $\mathrm{N}$ - Nonane & 0.469 \\
\hline 2 - Methyloctane & 0.505 \\
\hline $\mathrm{N}$ - Decane & 0.464 \\
\hline 2 - methylnonane & 0.448 \\
\hline $\mathrm{N}$ - Undecane & 0.436 \\
\hline $\mathrm{N}$ - Duodecane & 0.412 \\
\hline Average & 0.398 \\
\hline \multicolumn{2}{|l|}{ Halogenated hydrocarbons } \\
\hline Methylene chloride & 0.010 \\
\hline Chloroform $\left(\mathrm{CHCL}_{3}\right)$ & - \\
\hline Methylchloroform & 0.001 \\
\hline Trichloethylene & 0.066 \\
\hline Tetrachloroethylene & 0.005 \\
\hline Allyl chloride $\left(\mathrm{CH}_{2} \mathrm{CHCH}_{2} \mathrm{CL}\right)$ & - \\
\hline Average & 0.021 \\
\hline \multicolumn{2}{|l|}{ Alcohols } \\
\hline Methanol & 0.123 \\
\hline Ethanol & 0.268 \\
\hline I - Propanol & - \\
\hline Butanol & - \\
\hline I - Butanol & - \\
\hline Butane $-2-$ diol & - \\
\hline Average & 0.196 \\
\hline \multicolumn{2}{|l|}{ Aldehydes } \\
\hline Formaldehyde & 0.421 \\
\hline Acetaldehyde & 0.527 \\
\hline Propionaldehyde & 0.603 \\
\hline Butyraldehyde & 0.568 \\
\hline
\end{tabular}


Substância

PFOF

(Média de 3 regiões da Europa)

Aldehydes

I - Butyraldehyde

0.631

Valeraldehyde

0.686

Acroleine

Benzaldehyde

0.334

Average

0.443

\section{Ketones}

Acetone

0.178

Methyl ethyl Ketone

0.473

Methyl i - butyl Ketone

-

Average

0.326

\section{Esters}

Dimethylester

Methyl acrylate

Ethyl acetate

0.218

I - Propyl acetate

0.215

$\mathrm{N}$ - Butyl acetate

0.323

I - Butyl acetate

0.332

Average

0.223

\section{Olefins}

Ethene

1.000

Propene

1.030

1 - Butene

0.959

2 - Butene

0.992

1 - Pentene

1.059

2 - Pentene

0.930

2-Methyl - 1 - butene

0.777

2-Methyl-2-butene

0.779

3-Methyl-1-butene

0.895

Isobutene

0.634

Average

0.906

Acethylenes

Acethylene

0.168

\section{Aromatics}

Benzene

0.189

Toluene

0.563

O - Xylene

0.666

$\mathrm{M}$ - Xylene

0.993

$P$ - Xylene

0.888

Ethylbenzene

0.593

1,2,3 - Trimethylbenzene

1.170

1,2,4 - Trimethylbenzene

1.200

1,3,5 - Trimethylbenzene

1.150

$\mathrm{O}$ - Ethyltoluene

0.668

$M$ - Ethyltoluene

0.794

$P$ - Ethyltoluene

0.725

$\mathrm{N}$ - Propylbenzene

0.492

I - Propylbenzene

0.565

Average

0.761 
Substância

PFOF

(Média de 3 regiões da Europa)

Other

Methylcyclohexane

Isoprene

Dimethylether

Propylene glycole methyl ether

Propylene glycole methyl ether acetate

Carbonmonoxide

Conclusão

Tabela 4 - Potencial de Acidificação (PAc) dado em kgSO2-eq/kg-gas (Hauschild \& Wenzel, 1997, apud Carvalho, C. E.)

\begin{tabular}{lcc}
\hline \multicolumn{1}{c}{ Substância } & Fórmula & PAC \\
\hline Sulfur dioxide & $\mathrm{SO}_{2}$ & 1 \\
Súlfur trioxide & $\mathrm{SO}_{3}$ & 0.80 \\
Nitrogen dioxide & $\mathrm{NO}_{2}$ & 0.70 \\
Nitrogen oxide & $\mathrm{NO}$ & 1.07 \\
Hydrogen chloride & $\mathrm{HCL}$ & 0.88 \\
Hydrogen nitrate & $\mathrm{HNO}_{3}$ & 0.51 \\
Hydrogen sulfate & $\mathrm{H}_{2} \mathrm{SO}_{4}$ & 0.65 \\
Hydrogen phosphate & $\mathrm{H}_{3} \mathrm{PO}_{4}$ & 0.98 \\
Hydrogen fluoride & $\mathrm{HF}$ & 1.60 \\
Hydrogen sulfide & $\mathrm{H}_{2} \mathrm{~S}$ & 1.88 \\
Ammonium & $\mathrm{NH}_{3}$ & 1.88 \\
\hline
\end{tabular}

Tabela 5 - Potencial de Eutrofização (PEu) dado em $\mathrm{kgPO}_{4}$-eq/kg-gas (Lindfords et al., 1995, apud Carvalho, C. E.)

\begin{tabular}{lc}
\hline \multicolumn{1}{c}{ Substância } & $\begin{array}{c}\text { PEu } \\
\text { (máximo) }\end{array}$ \\
\hline Emissões para o Ar & 1 \\
phosphate & 0.42 \\
NOx & 0.13 \\
NOx & 0.35 \\
NH3 & \\
Emissões para a Água & \\
N & 0.42 \\
NO3 & 0.1 \\
NH4+ & 0.33 \\
P & 3.06 \\
CO4- & 1 \\
COD & 0.022 \\
\hline
\end{tabular}


Tabela 6 - Potencial Equivalente de Metais Pesados (PEMP) dado em kgPb-eq/kg/gás (EcoIndicador, 1995, apud Carvalho, C. E.)

\begin{tabular}{lc}
\hline \multicolumn{1}{c}{ Substância } & PEMP \\
\hline Emissões para o Ar & 50 \\
Cadmium oxide & 50 \\
$\mathrm{Cd}$ & 1 \\
$\mathrm{Hg}$ & 1 \\
$\mathrm{Mn}$ & 1 \\
$\mathrm{~Pb}$ & 1 \\
$\mathrm{As}$ & \\
& \\
Emissões para a Água & 0.13 \\
$\mathrm{~B}$ & 0.14 \\
$\mathrm{Ba}$ & 3 \\
$\mathrm{Cd}$ & 0.2 \\
$\mathrm{Cr}$ & 0.005 \\
$\mathrm{Cu}$ & 10 \\
$\mathrm{Hg}$ & 0.02 \\
$\mathrm{Mn}$ & 0.14 \\
$\mathrm{Mo}$ & 0.5 \\
$\mathrm{Ni}$ & 1 \\
$\mathrm{~Pb}$ & 2 \\
$\mathrm{Sb}$ & 2 \\
\hline
\end{tabular}

Tabela 7 - Potencial de Toxicidade Humana (PTH) dado em kgPAH-eq/kg-gas (Eco-Indicador, 1995, citado por Carvalho, C. E.)

\begin{tabular}{|c|c|}
\hline Substância & PTH \\
\hline As & 0.044 \\
\hline Benzene & 10.000011 \\
\hline Benzo [a] pyrene & 1 \\
\hline $\mathrm{Cr}(6+)$ & 0.44 \\
\hline CxHy aromatic & 0.00011 \\
\hline Ethylbenzene & 0.000011 \\
\hline Fluoranthene & 1 \\
\hline $\mathrm{Ni}$ & 0.0044 \\
\hline PAH & 1 \\
\hline tar & 0.000011 \\
\hline
\end{tabular}

